\title{
Flora da Bahia: Asteraceae - Tribo Heliantheae
}

\author{
Maria Alves $^{1^{*}}$ \& Nádia Roque ${ }^{1,2, a}$ \\ ${ }^{1}$ Programa de Pós-Graduação em Botânica, Departamento de Ciências Biológicas, Universidade Estadual de \\ Feira de Santana, Feira de Santana, Bahia, Brasil. \\ ${ }^{2}$ Instituto de Biologia, Universidade Federal da Bahia, Campus Universitário de Ondina, Salvador, Bahia, Brasil.
}

Resumo - Neste trabalho, é apresentado o tratamento taxonômico de Heliantheae (Asteraceae) para o estado da Bahia. Ele está baseado em 22 expedições de coleta e no material dos principais herbários brasileiros. A tribo está representada por 28 gêneros e 65 espécies na Bahia e Aspilia (15 espécies), Aldama (9) e Verbesina (5) são os gêneros mais representativos no estado. São apresentados chaves de identificação para gêneros e espécies, descrições, ilustrações e comentários sobre os táxons, além de mapas de distribuição geográfica das espécies no estado.

Palavras-chave adicionais: Aliança Heliantheae, Compositae, inventário florístico, Nordeste do Brasil, sistemática.

\begin{abstract}
Flora of Bahia: Asteraceae - Tribe Heliantheae) - The taxonomic treatment of the Heliantheae (Asteraceae) from the state of Bahia, Brazil, is presented here. The study is based on 22 field trips and material from the most important Brazilian herbaria. The tribe is represented by 28 genera and 65 species in Bahia and Aspilia (15 species), Aldama (9) and Verbesina (5) are the most representative genera in the state. Identification keys for the genera and species, descriptions, illustrations and comments are presented to the taxa as well as maps of species distribution in the state.
\end{abstract}

Additional key words: Compositae, floristic survey, Heliantheae Alliance, Northeast Brazil, systematics.

Asteraceae possui 43 tribos com aproximadamente 1700 gêneros e 24.000 espécies e apresenta distribuição cosmopolita (Funk et al. 2009). A família é monofilética (Funk et al. 2009) e caracterizada por possuir flores em capítulos com maturação centrípeta, sépalas modificadas em pápus, anteras sinânteras, com apresentação secundária do pólen, e ovário bicarpelar ínfero que se desenvolve em uma cipsela com um óvulo ereto, de placentação basal (Roque \& Bautista 2008). No Brasil, são registradas 2052 espécies, aproximadamente 275 gêneros e 28 tribos, encontradas em todas as vegetações brasileiras (Nakajima et al. 2015). Três tratamentos para táxons da família foram apresentados até o momento para a Flora da Bahia: o gênero Piptocarpha (Zugaib \& Amorim 2014), a subtribo Vernoniinae (Ogasawara \& Roque 2015) e a tribo Millerieae (Gandara et al. 2016); os dois primeiros tratamentos contam com descrições formais para as Asteraceae.

\section{HELIANTHEAE}

Ervas anuais ou perenes, arbustos, lianas ou árvores. Folhas alternas ou opostas, lâminas simples, raramente divididas, geralmente trinervadas. Capitulescências paniculiformes ou corimbiformes, terminais ou raramente axilares, às vezes capítulos solitários em longos pedúnculos, raramente sésseis, às vezes organizados em capítulos de segunda ordem. Capítulos radiados, discoides ou raramente disciformes; invólucro cilíndrico, campanulado ou hemisférico, às vezes reflexo ou patente; brácteas involucrais em 1-7 séries, subiguais, geralmente as mais internas menores, assemelhando-se a páleas; receptáculo achatado a convexo, cônico ou colunar, geralmente com páleas conduplicadas e persistentes, geralmente com 1 pálea na base de cada flor. Flores do raio femininas férteis ou estéreis, ou neutras. Flores do disco bissexuadas ou funcionalmente masculinas, raramente funcionalmente femininas; estames (3-)5, anteras geralmente com apêndice do conectivo ovado e apêndice basal sagitado; ramos do estilete geralmente com um tufo de papilas nas extremidades distais. Cipselas normalmente compressas ou obcompressas, lisas, estriadas, tuberculadas ou rugosas, às vezes aladas; pápus de aristas, escamas, coroniforme, às vezes reduzido, caduco ou ausente.

Heliantheae possui 113 gêneros e ca. 1460 espécies, com ocorrência no México, América Central e América do Sul (Baldwin 2009). No Brasil, são registrados 29 gêneros e 219 espécies, sendo a terceira maior tribo no país (Nakajima et al. 2015). Na Bahia, foram encontrados 28 gêneros e 64 espécies. A tribo possui importância econômica especialmente relacionada ao girassol comercial (Helianthus annuus L.), cultivado no mundo todo (Panero 2007).

\footnotetext{
*Autora para correspondência: maria.alves1987@hotmail.com;

a nadiaroque@gmail.com

Editor responsável: Alessandro Rapini

Submetido: 31 maio 2016; aceito: 26 out. 2016

Publicação eletrônica: 25 nov. 2016; versão final: 9 dez. 2016
} 


\section{Chave para os gêneros}

1. Planta com dois tipos de capítulo: capítulos com flores femininas sem perianto, unifloros ou bifloros, com invólucro envolvendo completamente a cipsela e capítulos com várias flores masculinas.

2. Brácteas involucrais dos capítulos masculinos conatas; invólucro das flores femininas com ou sem projeções cônicas no ápice quando maduras

2'. Brácteas involucrais dos capítulos masculinos livres; invólucro das flores femininas uncinado ou espinescente

1'. Planta com um único tipo de capítulo.

3. Capítulos com 1-4 flores.

4. Capítulos unifloros agrupados, formando um capítulo secundário

4'. Capítulos com 2-4 flores não agrupados.

14. Lagascea

5. Capítulos com 2 flores e 3 brácteas involucrais (1 maior circular e 2 menores elípticas); cipsela sem alas

9. Delilia

5'. Capítulos com 4 flores e 2 brácteas involucrais (subiguais, lanceoladas ou ovadas) (Figura 38E); geralmente 2 cipselas com alas laceradas (Figura 38F)

22. Synedrellopsis

3'. Capítulos com 6 ou mais flores.

6. Capítulos disciformes ( 3 ou mais flores funcionalmente masculinas, ovário estéril, e 1 a várias femininas ou bissexuadas).

7. Invólucro campanulado; pápus coroniforme diminuto

12. Eleutheranthera

7'. Invólucro ovoide, obovoide, amplamente obovoide ou elipsoide; pápus ausente.

8. Brácteas involucrais 4, em 2 séries; capítulos com 1 flor feminina; receptáculo epaleáceo

17. Riencourtia

8'. Brácteas involucrais 3, em 1 série; capítulos com 3 ou 4 flores femininas; receptáculo paleáceo ...

8. Clibadium

6'. Capítulos discoides (todas as flores bissexuadas) ou radiados (com flores bissexuadas e flores femininas, às vezes estéreis ou neutras).

9. Cipsela com duas extensões no ápice, subentendida por uma bráctea involucral e associada a duas flores do disco envolvidas por páleas (Figura 31C); flores do disco funcionalmente masculinas

16. Parthenium

9'. Cipsela sem o conjunto de características acima; flores do disco bissexuadas.

10. Pedúnculos fistulosos (ocos, espessos próximo ao capítulo) (Figuras 48B, D e 49G).

11. Brácteas involucrais com uma faixa azul-escura enegrecida no ápice; páleas com ápice fimbriado ou eroso; pápus ausente ou aristado

11'. Brácteas involucrais com coloração única; páleas com ápice aristado; pápus coroniforme, com 2 aristas, às vezes de 3 escamas livres

24. Tithonia

10'. Pedúnculos maciços (cilíndricos por toda a extensão).

12. Receptáculo cônico (Figuras 7A e 26A)

1. Acmella

12'. Receptáculo plano ou convexo.

13. Páleas do receptáculo com ápice setoso; pápus de cerdas decíduas .... 15. Melanthera

13'. Páleas do receptáculo com ápice agudo, acuminado, cuspidado, obtuso ou arredondado; pápus coroniforme (Figura 47E), aristado (Figura 31H), de escamas ou ausente.

14. Pápus de $2-5$ aristas.

15. Cipselas aladas (às vezes somente as das flores do raio).

16. Cipselas do raio com alas laceradas (Figura 38C) ........ 21. Synedrella

16'. Cipselas com alas inteiras

25. Verbesina

15'. Cipselas sem alas.

17. Cipselas com embrião confinado no centro e borda plana ao redor (Figura 31H) 19. Simsia

17'. Cipselas sem embrião confinado no centro.

18. Brácteas involucrais com estrias verdes (Figuras 17F e 27B); pápus de aristas intramarginais (Figura 17J, K) ...... 6. Blainvillea

18'. Brácteas involucrais sem estrias; pápus de aristas marginais

7. Calyptocarpus

14'. Pápus coroniforme ou coroniforme-aristado, de escamas ou ausente.

19. Folhas alternas ou as apicais alternas e as basais opostas.

20. Páleas envolvendo completamente as flores; cipselas dispersadas com as páleas enrijecidas, sem pápus

20'. Páleas conduplicadas (Figura 7D, H); cipselas dispersadas sem páleas, com pápus de escamas livres ou fundidas, aristado ou não. 
21. Pápus persistente

21'. Pápus decíduo

13. Helianthus

19'. Folhas opostas.

22. Brácteas involucrais da série externa similares às folhas em forma, textura e indumento (Figura 23B)

10. Dimerostemma

22'. Brácteas involucrais diferentes das folhas.

23. Cipselas tuberculadas, às vezes somente no ápice quando maduras (Figuras 17E e 23I).

24. Receptáculo com páleas filiformes (Figura 23H) 11. Eclipta

24'. Receptáculo com páleas lanceoladas, conduplicadas.

25. Ervas prostradas, estoloníferas; lacínias das flores do disco com tricomas na face adaxial .. 20. Sphagneticola

25'. Ervas ou arbustos eretos; lacínias das flores do disco sem tricomas na face adaxial

5. Baltimora

23'. Cipselas lisas.

26. Cipselas carnosas quando maduras (bacáceas); páleas com ápice cuspidado (Figura 35F)

26'. Cipselas não carnosas quando maduras; páleas com ápice agudo, acuminado, obtuso ou arredondado.

27. Flores do raio neutras ou femininas estéreis (sem óvulo); cipselas com cicatriz basal 4. Aspilia

27'. Flores do raio femininas; cipselas sem cicatriz basal ....

26. Wedelia

\section{Acmella Rich. ex Pers.}

Ervas eretas ou decumbentes, anuais ou perenes. Folhas opostas, decussadas, basais ou ao longo dos ramos, pecioladas; lâmina filiforme a amplamente obovada, mais comumente ovada. Capítulos radiados ou discoides, terminais ou axilares, solitários ou em grupos de 2 ou 3; brácteas involucrais em 1-3 séries, lineares a amplamente ovadas ou elípticas; receptáculo cônico, paleáceo. Flores do raio femininas; corola do raio verdadeira, alva, alvo-esverdeada, lilás, amarela ou laranja. Flores do disco bissexuadas; corola tubulosa, alva, verde-esbranquiçada ou amarela; anteras com apêndice basal geralmente sagitado, ápice agudo, amarelas, castanhas ou enegrecidas; ramos do estilete com ápice obtuso. Cipselas obovoides ou elipsoides, as das flores do disco compressas, às vezes com projeções apicais ultrapassando a inserção da corola e, quando maduras, com margem espessada evidente, glabras a pubescentes ou levemente tuberculadas; pápus com 110 cerdas macias ou ausente.

$O$ gênero pode ser reconhecido pelas folhas pecioladas, receptáculos cônicos e pápus ausente ou de poucas cerdas macias (Jansen 1981). Acmella possui 30 espécies com distribuição neotropical e centro de diversidade nas Américas (Panero 2007). No Brasil, ocorrem 16 espécies (Nakajima et al. 2015), três na Bahia.

\section{Chave para as espécies}

1. Brácteas involucrais 5 ou 6 , em 1 série 1.3. A. uliginosa

1'. Brácteas involucrais 7-11, em 2 séries.

2. Lâmina foliar ovada ou amplamente ovada; capítulos $0,7-1 \mathrm{~cm}$ larg.; brácteas involucrais 4 $5 \times 2-3 \mathrm{~mm}$, ovadas
2'. Lâmina foliar lanceolada a ovada; capítulos 0,4 $0,7 \mathrm{~cm}$ larg.; brácteas involucrais 3-4 × ca. 1 $\mathrm{mm}$, lanceoladas 1.1. A. brachyglossa

1.1. Acmella brachyglossa Cass., Dict. Sci. Nat. (ed. 2) 50:258. 1827.

Figura 1.

Erva $0,3-0,5 \mathrm{~m}$ alt.; ramos compressos, estriados, glabrescentes ou esparsamente vilosos. Folhas com pecíolo 0,2-8 cm compr.; lâmina 1,4-6,9 × 0,7-2,8 cm, membranácea ou cartácea, levemente discolor, lanceolada ou ovada, ápice agudo, mucronado, margem inteira, crenada ou serreada, estrigosa, base arredondada ou decorrente, face adaxial esparsamente estrigosa, a abaxial estrigosa ou vilosa nas nervações. Capítulos solitários, ou 2 ou 3 fasciculados, no ápice dos ramos, $0,5-0,9 \times 0,4-0,7 \mathrm{~cm}$, radiados; pedúnculo $1,9-6,2 \mathrm{~cm}$ compr.; invólucro subgloboso ou campanulado, brácteas involucrais subiguais, 7-10, em 2 séries, 3-4 × ca. $1 \mathrm{~mm}$, lanceoladas, ápice agudo, margem inteira, verdes; páleas $2-2,5 \times$ ca. $1 \mathrm{~mm}$ compr., ovadas ou oblongas, conduplicadas, ápice agudo, obtuso ou truncado, às vezes eroso, margem inteira. Flores 89-141. Flores do raio ca. 7, 3-3,5 mm compr.; corola ca. $2 \mathrm{~mm}$ compr. (tubo ca. $1 \mathrm{~mm}$ compr., pubescente), amarela. Flores do disco 2-3 mm compr.; corola 1,5-2 $\mathrm{mm}$ compr. (tubo ca. $0,5 \mathrm{~mm}$ compr.), amarela; anteras ca. $0,5 \mathrm{~mm}$ compr., enegrecidas, apêndice do conectivo ca. $0,05 \mathrm{~mm}$ compr., ovado, amarelo, apêndice basal sagitado, filetes amarelos; estilete ca. $1 \mathrm{~mm}$ compr., amarelo, ramos do estilete ca. $0,3 \mathrm{~mm}$ compr., pubescentes. Cipselas 1-1,5 $\mathrm{mm}$ compr., obovoides, às vezes compressas ou obcompressas, enegrecidas, margem ciliada, carpopódio assimétrico; pápus ausente. 
Ocorre nas Américas Central e do Sul (Jansen 1985); no Brasil, em todas as Regiões do país (Nakajima et al. 2015). D5, D7, E9: áreas antropizadas. Encontrada com flores e frutos de junho a julho.

Material selecionado - Feira de Santana, $12^{\circ} 15^{\prime} \mathrm{S}, 38^{\circ} 58^{\prime} \mathrm{W}$, jul. 1982, K.B. Britto 24 (ALCB); Gentio do Ouro, $11^{\circ} 06^{\prime} 24^{\prime \prime S}$, 4243'14"W, 500 m s.n.m., jun. 1996, M.L. Guedes et al. PCD 3011 (ALCB); Jacobina, $11^{\circ} 01^{\prime} 07^{\prime \prime S}, 40^{\circ} 32^{\prime} 43^{\prime \prime W}, 632$ m s.n.m., jul. 1996, H.P. Bautista et al. PCD 3458 (ALCB); Santo Inácio, $11^{\circ} 05^{\prime} 48^{\prime \prime S}, 42^{\circ} 43^{\prime} 18^{\prime \prime W}, 536$ m s.n.m., jul. 2000, M.M. Silva et al. 470 (ALCB).

Acmella brachyglossa assemelha-se a A. uliginosa, diferenciando-se principalmente pelas brácteas involucrais (veja chave de identificação).

1.2. Acmella ciliata (Kunth) Cass., Dict. Sci. Nat. ed. 2. 24: 331. 1822. Spilanthes ciliata Kunth, Nov. Gen. Sp. (folio ed.) 4: 163. 1820.

Figura 1.

Erva 0,3-0,7 m alt.; ramos compressos, estriados, glabrescentes ou esparsamente vilosos. Folhas com pecíolo 0,4-3,6 cm compr.; lâmina 3,2-8,3 × 1,3-4,7 $\mathrm{cm}$, membranácea ou cartácea, levemente discolor, ovada ou amplamente ovada, ápice agudo, margem denteada a serreada, base truncada, arredondada, raramente atenuada, face adaxial glabrescente ou esparsamente estrigosa, a abaxial glabrescente ou esparsamente estrigosa nas nervações. Capítulos solitários, ou 2 ou 3 fasciculados, no ápice ou na axila dos ramos, 0,6-1 × 0,7-1 cm, radiados; pedúnculo 1,3$4,8 \mathrm{~cm}$ compr., invólucro subgloboso, brácteas involucrais subiguais, 9-11, em 2 séries, 4-5 × 2-3 $\mathrm{mm}$, ovadas, ápice agudo ou obtuso, margem inteira, pubescentes, verdes; páleas 3-4 mm compr., estreitooblongas ou oblongas, conduplicadas, ápice obtuso ou truncado, inteiro ou eroso, margem inteira. Flores 183 194. Flores do raio 7-9, 4-5 mm compr.; corola 2-3 mm compr. (tubo ca. $1 \mathrm{~mm}$ compr., glabrescente), amarela. Flores do disco 3-4 mm compr.; corola 1,5-2 $\mathrm{mm}$ compr. (tubo ca. 0,5 $\mathrm{mm}$ compr., glabrescente), amarela; anteras ca. $0,5 \mathrm{~mm}$ compr., enegrecidas, apêndice do conectivo ca. 0,05 mm, ovado, amarelo, apêndice basal sagitado, filetes amarelos; estilete ca. 1,5 mm compr., amarelo, ramos do estilete ca. 0,5 $\mathrm{mm}$ compr., pubescentes. Cipselas ca. $2 \mathrm{~mm}$ compr., obovoides, às vezes compressas ou obcompressas, enegrecidas ou castanhas com manchas enegrecidas, margem ciliada, às vezes com espessamento lateral, carpopódio assimétrico; pápus ausente.

Ocorre na América do Sul, tendo sido introduzida no Panamá e em alguns países da Ásia (Jansen 1985); no Brasil, ocorre em todas as Regiões do país (Nakajima et al. 2015). D6, D7, E7, E9, F8, G8: áreas antropizadas. Encontrada com flores e frutos o ano todo.

Material selecionado - Igrapiúna, 135' $19 " \mathrm{~S}, 39^{\circ} 12^{\prime 2} 28^{\prime \prime} \mathrm{W}$, 153 m s.n.m., jul. 2010, M.L. Guedes et al. 17460 (ALCB); Ilhéus, jun. 1981, J.L. Hage 971 (RB); Mundo Novo, 12²'00"S,

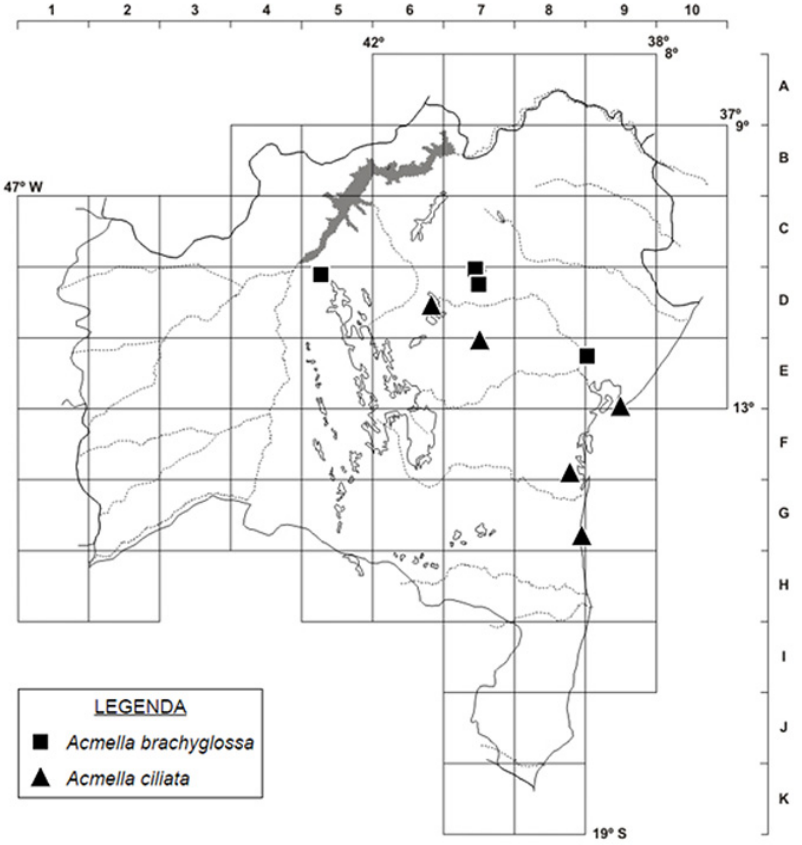

Figura 1. Mapa de distribuição geográfica de Acmella brachyglossa e A. ciliata no estado da Bahia.

40²9'00"W, 604 m s.n.m., jul. 2006, P.A. Melo 101 (ALCB); Salvador, $12^{\circ} 58^{\prime} \mathrm{S}, 38^{\circ} 30^{\prime} \mathrm{W}$, jan. 2000, L.M. Pacheco 43 (ALCB).

Jansen (1985) considera o espessamento lateral na cipsela (cork-like margin) uma característica-chave para o reconhecimento de $A$. ciliata. Contudo, alguns indivíduos de $A$. ciliata não apresentaram este espessamento lateral na cipsela enquanto alguns de $A$. uliginosa apresentaram um leve espessamento. Dentre as espécies com brácteas involucrais bisseriadas que ocorrem na Bahia, $A$. ciliata pode ser identificada pelas características mencionadas na chave.

\subsection{Acmella uliginosa (Sw.) Cass., Dict. Sci. Nat. (ed.}

2) 24: 331. 1822. Spilanthes uliginosa Sw., Prodr.

110. 1788 .

$=$ Spilanthes salzmannii DC., Prodr. 5: 623. 1836.

Figuras 2, 7 A-D e 26 A.

Erva ou arbusto 0,3-1 m alt.; ramos compressos, estriados, glabrescentes a esparsamente vilosos. Folhas com pecíolo 0,2-1,3 cm compr.; lâmina 1,6-8,7 × 0,7$2,3 \mathrm{~cm}$, membranácea ou cartácea, levemente discolor, lanceolada ou ovada, ápice agudo ou obtuso, margem inteira ou serreada, às vezes estrigosa e sinuosa, base atenuada ou decorrente, face adaxial esparso estrigosa, a abaxial estrigosa nas nervações. Capítulos solitários, ou 2 ou 3 fasciculados, no ápice ou na axila dos ramos; capítulos $0,4-0,8 \times 0,4-0,6 \mathrm{~cm}$, radiados; pedúnculo 1,1-7,1 cm compr.; invólucro campanulado, brácteas involucrais subiguais, 5 ou 6 , em 1 série, 2,5-4 × 1-1,5 $\mathrm{mm}$, lanceoladas ou ovadas, ápice obtuso, margem inteira, verdes; páleas 2-3 3 ca. $1 \mathrm{~mm}$, estreitoelípticas ou elípticas, conduplicadas, ápice arredondado ou truncado, geralmente eroso, margem inteira. Flores 70-138. Flores do raio ca. 5, ca. $3 \mathrm{~mm}$ compr.; corola ca. $2 \mathrm{~mm}$ compr. (tubo ca. $1 \mathrm{~mm}$ compr.), amarela ou 
amarelo-pálida; Flores do disco 2,5-3 $\mathrm{mm}$ compr.; corola 1,1-1,5 mm compr. (tubo ca. $0,5 \mathrm{~mm}$ compr.), amarela; anteras ca. $0,5 \mathrm{~mm}$ compr., enegrecidas, apêndice do conectivo ca. $0,05 \mathrm{~mm}$, triangular, amarelo, apêndice basal sagitado, filetes amarelos; estilete ca. 1,1 mm compr., amarelo, ramos do estilete ca. 0,2 mm compr. Cipselas 1,5-2 $\mathrm{mm}$ compr., elipsoides, geralmente compressas, enegrecidas, margem ciliada, raramente com espessamento lateral, carpopódio assimétrico; pápus ausente.

Ocorre nas América Central e do Sul e em alguns locais da Ásia (Jansen 1985); no Brasil, nas Regiões Norte, Nordeste, Centro-oeste (Goiás) e Sudeste (Nakajima et al. 2015). B4, D5, D6, D7, E6, E7, E8, E9, F3, F6, F8, G5, G8, H8: áreas antropizadas. Encontrada com flores e frutos o ano todo.

Material selecionado - Anguera, $12^{\circ} 10^{\prime} 59^{\prime \prime} \mathrm{S}, 39^{\circ} 09^{\prime} \mathrm{W}, 130 \mathrm{~m}$ s.n.m., ago. 1996, F. França et al. 1767 (HUEFS); Cachoeira, $12^{\circ} 37^{\prime} \mathrm{S}, 38^{\circ} 57^{\prime} \mathrm{W}$, jul. 2006, M.L. Guedes et al. 12112 (ALCB); Camacã, $15^{\circ} 23^{\prime} 30^{\prime \prime S}, 39^{\circ} 33^{\prime} 55^{\prime \prime W}$, 800-900 m s.n.m., jul. 2011, A.M. Amorim 8024 (RB); Campo Alegre de Lourdes, 09॰30'56"S, $43^{\circ} 00^{\prime} 40^{\prime \prime} \mathrm{W}$, maio 2000, L.P. Queiroz 6208 (HUEFS); Castro Alves, 1243'19"S 39॰21'43"W, out. 2013, L.Y.S. Aona \& G. Costa 3242 (HUEFS); Contendas do Sincorá, $13^{\circ} 55^{\prime} 07^{\prime} \mathrm{S}, 41^{\circ} 09^{\prime} 44^{\prime} \mathrm{W}$, abr. 2003, N. Roque et al. 668 (ALCB); Correntina, $13^{\circ} 20^{\prime} \mathrm{S}, 44^{\circ} 38^{\prime} \mathrm{W}, 580 \mathrm{~m}$ s.n.m., abr. 1980, R.M. Harley et al. 21631 (RB); Feira de Santana, $12^{\circ} 16^{\prime} 32^{\prime \prime S}$, 39³'22"W, abr. 1997, F. França et al. 2194 (HUEFS); Igrapiúna, 135' 19 "S, 39012'28"W, 153 m s.n.m., jul. 2010, M.L. Guedes 17460 (ALCB); Ipecaetá, 12²0'S, 39¹7'W, ago. 1985, L.R. Noblick \& C.G. Lôbo 4276 (ALCB); Ipirá, jul. 1984, E.L.P.G. Oliveira 754 (ALCB); Itacaré, ago. 2003, R.N. Querino 1 (ALCB); Lençóis, out. 1996, D.J.N. Hind \& L. Funch PCD 3796 (ALCB); Licínio de Almeida, 14²41'33"S, 42³1'52"W, 785 m s.n.m., maio 2013, M. Alves et al. 166 (HUEFS); Miguel Calmon, $11^{\circ} 22^{\prime} 52^{\prime \prime S}, 40^{\circ} 34^{\prime} 59^{\prime \prime W}, 547$ m s.n.m., dez. 2006, M.L. Guedes et al. 13213 (ALCB); Morro do Chapéu, $11^{\circ} 15^{\prime} 32^{\prime \prime S}$,

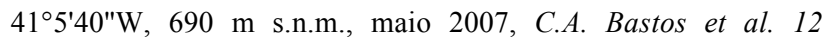
(ALCB); Mucugê, $13^{\circ} 00^{\prime} 03^{\prime \prime S}, 41^{\circ} 23^{\prime} 09^{\prime \prime W}, 987$ m s.n.m., jul. 2009, N. Roque et al. 2112 (ALCB); Mundo Novo, 1201'59"S, 40²8'59"W, 604 m s.n.m., jul. 2006, P.A. Melo 97 (HUEFS); Piritiba, $11^{\circ} 43^{\prime} \mathrm{S}, 40^{\circ} 33^{\prime} \mathrm{W}$, maio 1980 , L.R. Noblick 1847 (ALCB); Rio de Contas, 133' $13^{\prime \prime S}, 41^{\circ} 45^{\prime} 54^{\prime \prime} \mathrm{W}, 895$ m s.n.m., fev. 2004, R.M. Harley et al. 54844 (ALCB); Salvador, 12 ${ }^{\circ} 58^{\prime} \mathrm{S}$, 38³0'W, out. 1999, L.M. Pacheco 42 (ALCB); Serra Preta, $12^{\circ} 10^{\prime} \mathrm{S}, 39^{\circ} 20^{\prime} \mathrm{W}$, jul. 1985, L.R. Noblick \& Lemos 4159 (ALCB); Valença, set. 1957, R.P. Lordelo 57-768 (ALCB).

Acmella uliginosa pode ser distinguida das demais espécies de Acmella na Bahia por possuir 5 ou 6 brácteas involucrais unisseriadas.

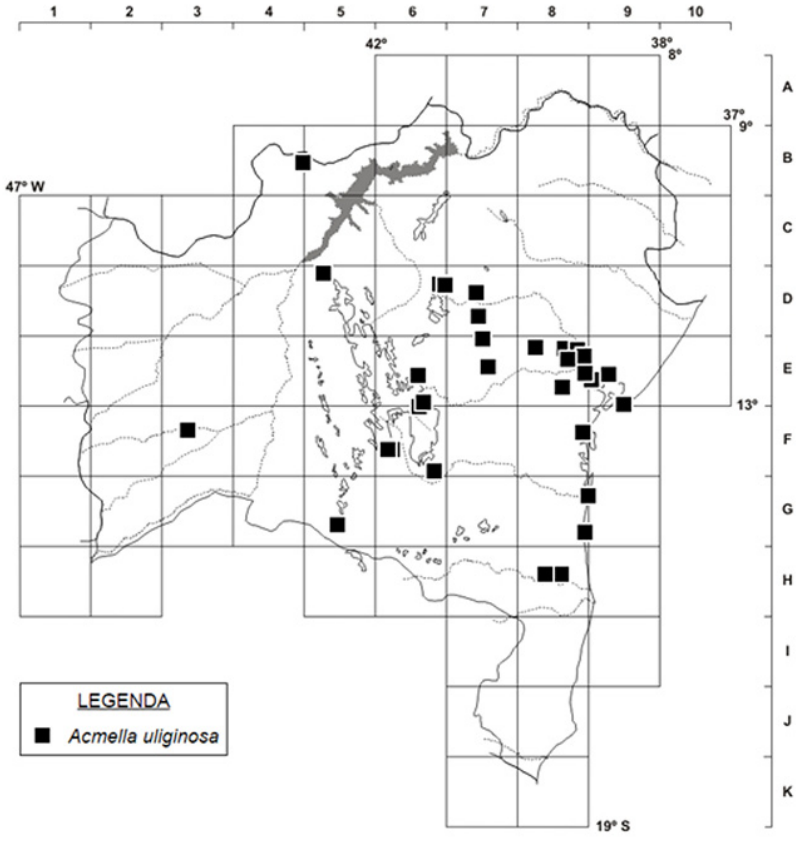

Figura 2. Mapa de distribuição geográfica de Acmella uliginosa no estado da Bahia.

\section{Aldama La Llave}

Ervas, anuais ou perenes, arbustos, raramente árvores. Folhas alternas ou opostas e alternas próximas à inflorescência; lâmina linear, oblonga, ovada, largamente ovada ou orbicular. Capítulos radiados, raro discoides, solitários ou em cimeiras racemosas ou paniculiformes, congestas ou laxas; brácteas involucrais subiguais ou as internas gradativamente maiores que as externas, em 2-7 séries; receptáculo convexo ou cônico, paleáceo. Flores do raio neutras; corola do raio verdadeira, ápice 2- ou 3-lobado, geralmente amarela. Flores do disco bissexuadas; corola tubulosa, 5laciniada, amarela, raro vermelha; anteras castanhas ou enegrecidas, filetes glabros; estilete com alargamento basal, inserido em um estilopódio. Cipselas obovoides, simétricas, estriadas; pápus marginal ou intramarginal de escamas ou de escamas e aristas, persistente.

As espécies brasileiras de Aldama são caracterizadas pelo receptáculo com páleas naviculares de ápice agudo, obtuso ou truncado, que envolvem apenas parcialmente a flor, e cipselas simétricas com pápus persistente (Magenta et al. 2010). O gênero possui 112 espécies distribuídas do sudoeste da América do Norte e México até a América do Sul (Magenta \& Pirani 2014). No Brasil, são encontradas 35 espécies (Nakajima et al. 2015), nove na Bahia.

\section{Chave para as espécies}

1. Brácteas involucrais similares em tamanho e forma.

2. Lâmina foliar linear, 0,06-0,08 cm larg., margem revoluta

2'. Lâmina foliar lanceolada, ovada, oblonga, amplamente oblonga, obovada, estreito-elíptica ou elíptica, 0,9$4,4 \mathrm{~cm}$ larg., margem plana.

3. Lâmina foliar com face abaxial tomentosa.

4. Ramos vilosos; lâmina foliar com face adaxial vilosa e abaxial tomentosa; flores do raio 7-9 
4'. Ramos tomentosos; lâmina foliar com face adaxial estrigosa e abaxial alvo-tomentosa; flores do raio ca. 12 2.3. A. aff. discolor

3'. Lâmina foliar com face abaxial híspida, hirsuta ou estrigosa nas nervações.

5. Lâmina foliar com face adaxial hirsuta ou setosa; capítulos 1,4-1,9 $\times 2-3 \mathrm{~cm} \ldots$. ... 2.5. A. grandiflora

5'. Lâmina foliar com face adaxial híspida ou estrigosa nas nervações; capítulos $0,9-1,1 \times 1,2-1,8 \mathrm{~cm} \ldots$

2.1 A. bakeriana

1'. Brácteas involucrais gradativamente maiores (as mais internas maiores que as mais externas).

6. Páleas com ápice truncado

2.9. A. veredensis

6'. Páleas com ápice arredondado ou acuminado.

7. Pedúnculos longos, ca. $28,6 \mathrm{~cm}$ compr., flexuosos

7'. Pedúnculos curtos, 0,1-3,1 cm compr., eretos.

8. Lâmina foliar linear ou estreito-elíptica, ápice acuminado

2.7. A. oblongifolia

8'. Lâmina foliar elíptica ou oblonga, ápice agudo

2.2. A. bracteata

2.8. A. robusta

2.1. Aldama bakeriana (S.F.Blake) E.E.Schill. \& Panero, Bot. J. Linn. Soc. 167(3): 322. 2011. Viguiera bakeriana S.F.Blake, Contr. Gray Herb. 54: 130.1918.

Figura 3.

Erva ou subarbusto $0,3-0,8 \mathrm{~m}$ alt.; ramos cilíndricos, estriados, estrigosos. Folhas opostas, às vezes as apicais alternas, sésseis ou curto-pecioladas (pecíolo até $0,3 \mathrm{~cm}$ compr.); lâmina 5,5-9,5 × 1,5-3(4) cm, cartácea, discolor, oblonga, amplamente oblonga ou obovada, ápice geralmente agudo ou obtuso, margem serreada na metade apical, base cuneada ou arredondada, face adaxial híspida ou estrigosa nas nervações, a abaxial híspida ou hirsuta nas nervações. Capitulescências em cimeiras racemosas; pedúnculo 5-38 cm compr., bractéolas ca. $6 \times 1 \mathrm{~mm}$, ápice agudo, margem inteira. Capítulos 0,9-1,1 $\times$ 1,2-1,8 cm, radiados; invólucro campanulado, brácteas involucrais subiguais, ca. 20, em 2 ou 3 séries, 5-11 × 1,5-2,5 mm, lanceoladas, ápice acuminado, margem inteira, ciliada, verdes; receptáculo convexo, páleas $9-10 \times$ ca. $2 \mathrm{~mm}$, estreitooblongas, conduplicadas, persistentes, carenadas, ápice agudo, mucronado, eroso, margem inteira. Flores 6570. Flores do raio 10-12, 27-31 mm compr.; corola 20-25 mm compr. (tubo ca. $1 \mathrm{~mm}$ compr.), amarela. Flores do disco 6-9 mm compr.; corola 4-4,5 $\mathrm{mm}$ compr. (tubo ca. 0,5 mm compr.), amarela; anteras ca. $3 \mathrm{~mm}$ compr., apêndice do conectivo ca. 0,5 mm compr., ovado, amarelo, ápice agudo, apêndice basal sagitado, filetes amarelos; estilete ca. $9 \mathrm{~mm}$ compr., amarelo, ramos do estilete ca. 1,5 $\mathrm{mm}$ compr., ápice agudo, pubescente. Cipselas 4-4,5 $\mathrm{mm}$ compr., obovoides, carpopódio inconspícuo; pápus de escamas livres ou parcialmente fundidas $1,5-1,8 \mathrm{~mm}$ compr., com 2 aristas de $2-3 \mathrm{~mm}$ compr., pubescentes.

Endêmica do Brasil, nos estados de Minas Gerais e Bahia (Magenta \& Pirani 2014). G8: cerrado. Encontrada com flores e frutos em agosto.

Não foram encontradas coletas recentes desta espécie. De acordo com Magenta \& Pirani (2014), o único espécime citado para a Bahia (Silveira 205 em R) é do ano de 1894, no município de Ilhéus. Este material, entretanto, não foi encontrado. Assim, a descrição da espécie está baseada na literatura (Magenta 2006) e na imagem em alta resolução do material-tipo Glaziou 15077 (K; no site plants.jstor.org).

2.2. Aldama bracteata (Gardner) E.E.Schill. \& Panero, Bot. J. Linn. Soc. 167(3): 322. 2011. Viguiera bracteata Gardner, London J. Bot. 7: 404. 1848.

Figuras 3, 7E-H e 26 B.

Arbusto ca. $1 \mathrm{~m}$ alt.; ramos cilíndricos, estriados, glabrescentes ou estrigosos, raramente tomentosos. Folhas alternas, sésseis; lâmina 5,3-9,6 (12,7) × 0,3$0,5(1,7) \mathrm{cm}$, coriácea, discolor, linear ou estreitoelíptica, ápice acuminado, margem inteira ou serreada, base cuneada, estrigosa em ambas as faces, às vezes tomentosa, abaxialmente glandulosa. Capitulescências em cimeiras racemosas; pedúnculo 1,6-13,1 cm compr., ereto. Capítulos 0,9-1,4 × 0,9$1,6 \mathrm{~cm}$, radiados; invólucro campanulado, brácteas involucrais gradativamente maiores, $27-36$, em 4 ou 5 séries, as mais externas $4-5 \times 1-1,5 \mathrm{~mm}$, as mais internas $8-10 \times 2,5-3 \mathrm{~mm}$, lanceoladas, ápice agudo ou acuminado, margem inteira, verdes, vilosas, às vezes somente nas margens; receptáculo convexo, páleas 8-9 × 2-3 $\mathrm{mm}$, lanceoladas, conduplicadas, persistentes, com carena ciliada, ápice arredondado, eroso, ciliado, margem inteira. Flores 54-96. Flores do raio 8-14, 9,5-15,5 $\mathrm{mm}$ compr.; corola 8-14 $\mathrm{mm}$ compr. (tubo 1-2 mm compr., pubescente), amarela. Flores do disco 8-10 mm compr.; corola 5-6 mm compr. (tubo 1-2 mm compr., pubescente), amarela; anteras ca. 2,3 mm compr., apêndice do conectivo 0,2-0,3 mm compr., ovado, amarelo, ápice obtuso, apêndice basal sagitado, filetes amarelos; estiletes ca. $5 \mathrm{~mm}$ compr., amarelos, ramos do estilete 1,5-2 $\mathrm{mm}$ compr., ápice agudo, pubescente. Cipselas ca. $4 \mathrm{~mm}$ compr., obovoides, compressas, cinza ou enegrecidas, carpopódio inconspícuo, setosas; pápus de escamas livres ou parcialmente fundidas $1,5-2 \mathrm{~mm}$ compr., ápice eroso, com 1 ou 2 aristas de $2-4 \mathrm{~mm}$ compr., pubescentes.

Endêmica do Brasil, no Distrito Federal, Goiás, Mato Grosso do Sul e Minas Gerais (Magenta \& Pirani 2014), tendo sido registrada mais recentemente para o estado da Bahia (Alves et al. 2015). G5: cerrado. Encontrada com flores e frutos de maio a julho. 


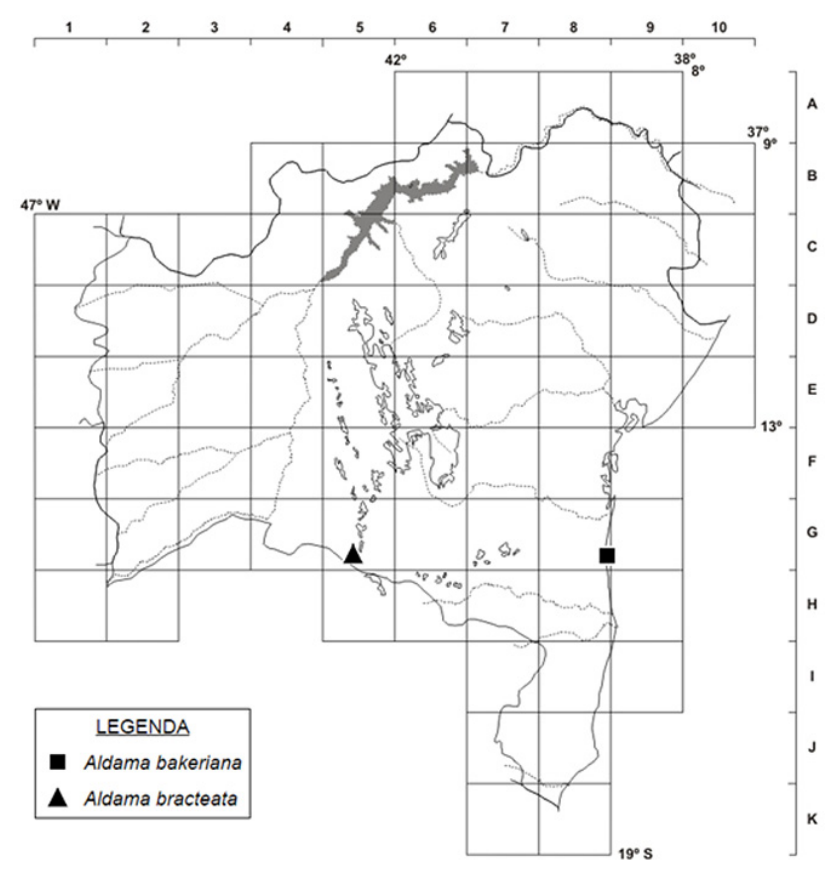

Figura 3. Mapa de distribuição geográfica de Aldama bakeriana e A. bracteata no estado da Bahia.

Material selecionado - Licínio de Almeida, 1446'16"S, 42³4'16"W, 1039 m s.n.m., maio 2013, M. Alves et al. 176 (ALCB, HUEFS); Urandi, $14^{\circ} 46^{\prime} 54^{\prime \prime} \mathrm{S}, 42^{\circ} 34^{\prime} 25^{\prime \prime} \mathrm{W}, 1115 \mathrm{~m}$ s.n.m., maio 2013, M. Alves et al. 184 (ALCB, HUEFS).

Dentre as espécies citadas para a Bahia, Aldama bracteata pode ser confundida com $A$. filifolia quando apresenta lâmina foliar linear, mas diferencia-se por possuir lâmina foliar discolor (vs. concolor em $A$. filifolia) com margem plana (vs. revoluta) e brácteas involucrais em 4 ou 5 séries (vs. 3 séries).

\subsection{Aldama aff. discolor (Baker) E.E.Schill. \&} Panero, Bot. J. Linn. Soc. 167(3): 322. 2011. Viguiera discolor Baker, Fl. Bras. 6(3): 228. 1884.

Figura 4; Baker (1884: prancha 68).

Arbusto ca. 1,5 m alt.; ramos cilíndricos, estriados, tomentosos. Folhas alternas, às vezes opostas; pecíolo 0,1-0,4 cm compr.; lâmina 3,4-8,2 × 1-2,3 cm, cartácea, fortemente discolor, lanceolada ou ovada, ápice agudo ou acuminado, mucronado, margem serreada, base cuneada ou atenuada, face adaxial estrigosa, a abaxial alvo-tomentosa, glandulosa. Capitulescências de 1-3 capítulos terminais, às vezes em cimeiras racemosas; pedúnculo 0,4-7,1 cm compr., brácteas foliáceas ca. $18 \times 7 \mathrm{~mm}$ compr., ápice agudo mucronado, margem inteira, face adaxial estrigosa, a abaxial tomentosa. Capítulos $0,8-1,1 \times 1-1,4 \mathrm{~cm}$, radiados; invólucro subgloboso ou campanulado, brácteas involucrais subiguais, ca. 19, em 2 ou 3 séries, 4-5,5 × 1,5-2 mm compr., lanceoladas ou ovadas, ápice acuminado, mucronado, margem inteira, vilosa, indumento alvo, verdes, estrigosas, às vezes glandulosas próximo ao ápice; receptáculo convexo, páleas 4-5 $\times$ ca. $2 \mathrm{~mm}$, ovadas ou oblongas, conduplicadas, persistentes, geralmente carenadas, ápice arredondado ou agudo, mucronado, às vezes ciliado, margem inteira. Flores ca. 104. Flores do raio ca. 12, 9-11 mm compr.; corola 7-8 mm compr. (tubo ca. $2 \mathrm{~mm}$ compr., glabrescente), amarela. Flores do disco 4-6 mm compr.; corola 2-3,5 $\mathrm{mm}$ compr. (tubo ca. 0,5 mm compr.), amarela; anteras ca. $2 \mathrm{~mm}$ compr., apêndice do conectivo ca. 0,2 mm compr., ovado, amarelo, ápice agudo, apêndice basal sagitado, filetes amarelos; estilete ca. $3 \mathrm{~mm}$ compr., amarelo, ramos do estilete ca. $1 \mathrm{~mm}$ compr., ápice agudo, pubescente. Cipselas ca. $2 \mathrm{~mm}$ compr., oblanceoloides, enegrecidas, carpopódio inconspícuo; pápus de escamas livres ou fundidas ca. 0,5 mm compr., com 2 aristas de 0,5-1,5 mm compr., pubescentes.

Possui registros para Goiás, Minas Gerais e São Paulo (Magenta \& Pirani 2014), sendo este o seu primeiro registro para o estado da Bahia. G6: cerrado. Encontrada com flores e frutos em março.

Material examinado - Brumado, $14^{\circ} 13^{\prime} 44^{\prime \prime} \mathrm{S}, 41^{\circ} 43^{\prime} 38^{\prime \prime} \mathrm{W}$, 648 m s.n.m., mar. 2002, H.P. Bautista et al. 3205 (HRB, HUEFS, SPF).

Aldama discolor é reconhecida principalmente pelo indumento esbranquiçado na face abaxial das folhas, característica apresentada no espécime encontrado na Bahia. De acordo com Magenta \& Pirani (2014), a espécie possui grande plasticidade e alguns espécimes de outros estados podem não apresentar indumento alvo-tomentoso na face abaxial. Foi encontrada uma única coleção com três exsicatas desta espécie para a Bahia e outras caraterísticas do material deixaram dúvidas quanto à identificação segura desta espécie.

2.4. Aldama filifolia (Sch.Bip. ex Baker) E.E.Schill. \& Panero, Bot. J. Linn. Soc. 167(3): 323. 2011. Viguiera filifolia Sch.Bip. ex Baker in Martius \& Eichler, Fl. Bras. 6(3): 219. 1884.

Figura 5.

Arbusto ca. 1,5 m alt.; ramos cilíndricos, estriados, glabrescentes ou glabros. Folhas alternas, sésseis; lâmina $1,5-6 \times 0,06-0,08 \mathrm{~cm}$, cartácea, concolor, linear, ápice agudo ou obtuso, margem inteira, revoluta, base cuneada, glabra ou esparso-estrigosa em ambas as faces. Capitulescências em cimeiras racemosas; pedúnculo 0,4-1 cm compr.; bractéolas 4-7 $\times$ ca. $1 \mathrm{~mm}$, ápice acuminado, margem inteira. Capítulos 1-1,3 × 1,2-1,6 cm, radiados; invólucro campanulado, brácteas involucrais subiguais, ca. 20, em 3 séries, 8-11 × 1,5-3 mm, lanceoladas, ápice acuminado, às vezes mucronado, margem inteira, ciliada, verdes; receptáculo convexo, páleas $6,5-8 \times 2-$ $3,5 \mathrm{~mm}$, estriadas, obovadas ou oblanceoladas, conduplicadas, persistentes, carenadas, carena ciliada, ápice arredondado ou obtuso, eroso, margem inteira. Flores ca. 52. Flores do raio 10, 22-24 mm compr.; corola 17-20 mm compr. (tubo 1,5-2 mm compr.), amarela. Flores do disco 8-9 mm compr.; corola 4-5 $\mathrm{mm}$ compr. (tubo 4-5 $\mathrm{mm}$ compr., esparso pubescente), amarela; anteras ca. $3 \mathrm{~mm}$ compr., 


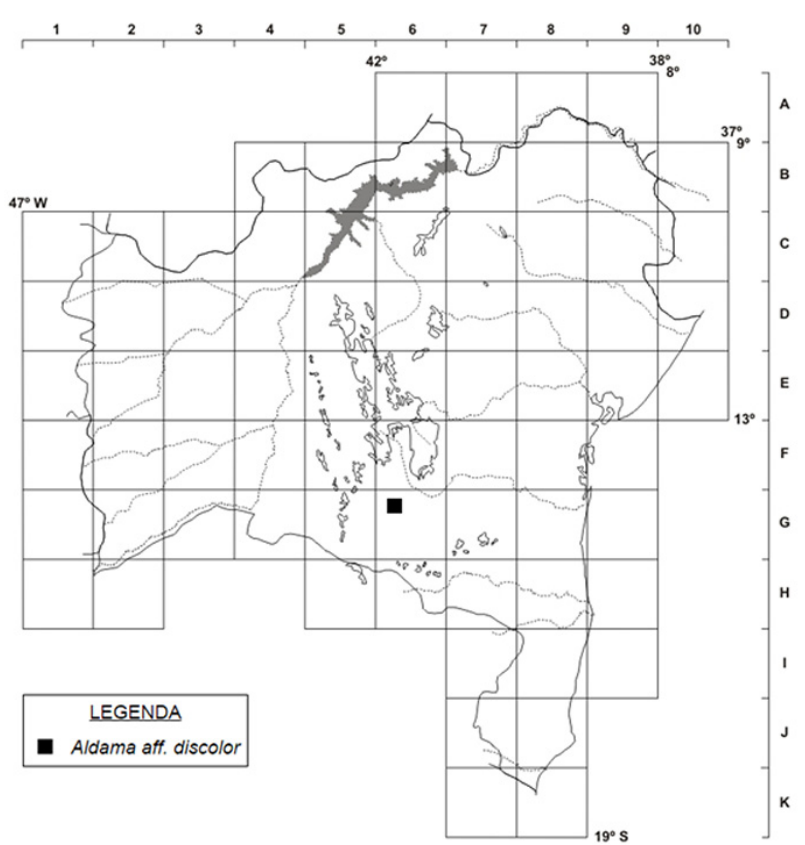

Figura 4. Mapa de distribuição geográfica de Aldama aff. discolor no estado da Bahia.

apêndice do conectivo ca. 0,5 mm compr., ovado, amarelo, ápice agudo, apêndice basal sagitado, filetes amarelos; estilete ca. $5 \mathrm{~mm}$ compr., amarelo, ramos do estilete ca. $1 \mathrm{~mm}$ compr., ápice agudo, pubescente. Cipselas imaturas ca. 3-4 mm compr., estreitooblongas, enegrecidas, seríceas, carpopódio inconspícuo; pápus de escamas até 1,5 mm compr., ápice eroso, com 1 ou 2 aristas de 2,5-3 mm compr., pubescentes.

Endêmica do Brasil, com registros nos estados de Goiás, Minas Gerais e Bahia (Magenta 2006). G5.

Material examinado - Caetité, s.d., C.F.P. von Martius s.n. (M 0111284- Síntipo; e-tipo- Species Link).

Material adicional examinado - BRASIL. GOIÁS: Teresina, 1356'7"S, 47²6'35"W, 1465 m s.n.m., abr. 2009, L.P. Queiroz et al. 14307 (HUEFS).

Não há registros recentes de coleta desta espécie no estado, sendo conhecido apenas um dos síntipos coletados na Bahia. Assemelha-se a Aldama bracteata (ver comentários daquela espécie).

2.5. Aldama grandiflora (Gardner) E.E.Schill. \& Panero, Bot. J. Linn. Soc. 167(3): 323. 2011. Viguiera grandiflora Gardner, London J. Bot. 7: 404. 1848.

Figura 5.

Arbusto ca. 0,7 m alt.; ramos cilíndricos ou compressos, estriados, glabrescentes ou estrigosos. Folhas alternas, as basais opostas, sésseis; lâmina 6,7$12,5 \times 3,3-4,4 \mathrm{~cm}$, cartácea, levemente discolor, estreito-elíptica ou elíptica, ápice agudo, margem crenada ou crenado-serreada, base arredondada ou cuneada, face adaxial hirsuta ou setosa, glandulosa, a abaxial estrigosa, hirsuta nas nervações. Capítulos 1 ou 2, terminais, 1,4-1,9 × 2-3 cm, radiados; pedúnculo
4,5-9,7 cm compr.; invólucro campanulado, brácteas involucrais subiguais, ca. 20, em 2 ou 3 séries, 7-10× 1,5-2 mm, lanceoladas, ápice acuminado ou caudado, margem inteira, ciliada, verdes; receptáculo convexo, páleas $7-8 \times$ ca. $3 \mathrm{~mm}$, ovadas, conduplicadas, persistentes, ápice acuminado, margem inteira, pubescentes na face abaxial. Flores ca. 35. Flores do raio 7, 26-28 mm compr.; corola 21-23 mm compr. (tubo 2-3 mm compr.), amarela. Flores do disco 8-9 $\mathrm{mm}$ compr.; corola 5-6 mm compr. (tubo 1,5-2 mm compr.), amarela; anteras ca. $3 \mathrm{~mm}$ compr., apêndice do conectivo ca. 0,5 mm compr., ovado, amarelo, ápice agudo, apêndice basal sagitado, filetes amarelos; estilete ca. 5,5 mm compr., amarelo, ramos do estilete ca. $1 \mathrm{~mm}$ compr., ápice agudo, pubescente. Cipselas 5-6 mm compr., oblanceoloides, castanhas com manchas enegrecidas, glabrescentes ou pubescentes na parte apical, carpopódio inconspícuo; pápus de escamas até $1 \mathrm{~mm}$ compr., ápice eroso.

Endêmica do Brasil, no Distrito Federal, Goiás, Mato Grosso do Sul, Minas Gerais e Bahia (Magenta \& Pirani 2014). F5: cerrado. Encontrada com flores e frutos em novembro.

Material selecionado - Rio de Contas, $13^{\circ} 22^{\prime} 07^{\prime \prime} \mathrm{S}$, 4253'03"W, 1800 m s.n.m., nov. 1996, R.M. Harley et al. 4296 (ALCB, HUEFS); Riacho de Santana, mar. 1999, F.H.F. Nascimento 169 (HUEFS).

Quando herborizada, é parecida com A. bakeriana, diferenciando-se principalmente pela lâmina foliar abaxialmente hirsuta ou setosa (vs. híspida ou estrigosa nas nervações em $A$. bakeriana).

2.6. Aldama nudibasilaris (S.F.Blake) E.E.Schill. \& Panero, Bot. J. Linn. Soc. 167(3): 324. 2011. Viguiera nudibasilaris S.F.Blake, Contr. Gray Herb. 54: 149. 1918.

Figura 5.

Arbusto ca. $2 \mathrm{~m}$ alt.; ramos cilíndricos, estriados, vilosos. Folhas opostas, às vezes alternas próximo à inflorescência; pecíolo 0,2-0,9 cm compr.; lâmina 4,7$13,3 \times 0,9-2,5 \mathrm{~cm}$, cartácea, fortemente discolor, lanceolada ou estreito-elíptica, ápice acuminado, mucronado, margem inteira ou serreada, base atenuada, face adaxial vilosa, a abaxial tomentosa, glandulosa. Capítulos 1 ou 2, terminais ou em cimeiras racemosas, 0,6-1 × 0,6-1,5 cm, radiados; pedúnculo 0,3-3,5 cm compr.; bractéolas foliáceas ao longo do pedúnculo 5$19 \times 1,5-4 \mathrm{~mm}$, ápice acuminado, margem inteira, face adaxial vilosa, a abaxial tomentosa; invólucro subgloboso ou campanulado, brácteas involucrais subiguais, ca. 19 , em 2 séries, 5-6 $\times$ ca. 2 mm, ovadas, ápice acuminado, mucronado, reflexo, margem inteira, ciliada, verdes, pubescentes, vilosas próximo ao ápice; receptáculo convexo, páleas $5-6 \times$ ca. $2 \mathrm{~mm}$, lanceoladas, conduplicadas, persistentes, geralmente carenadas, ápice agudo, margem inteira, às vezes ciliada. Flores 73-114. Flores do raio 7-9, 12-14 mm compr.; corola 10-12 mm compr. (tubo ca. $1 \mathrm{~mm}$ 


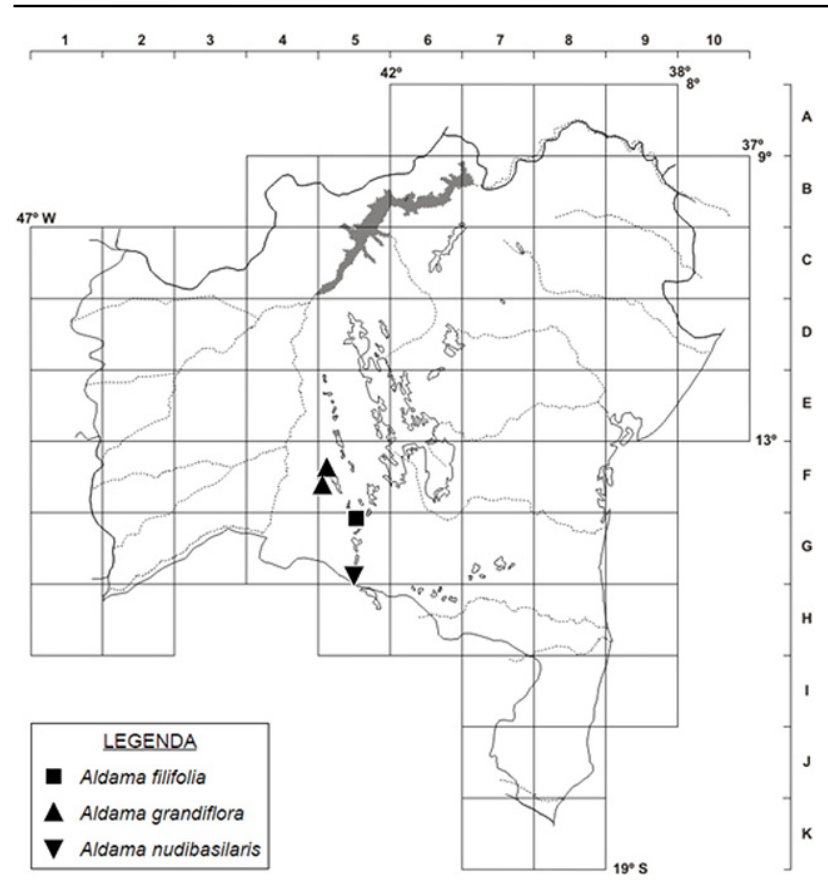

Figura 5. Mapa de distribuição geográfica de Aldama filifolia, A. grandiflora e A. nudibasilaris no estado da Bahia.

compr., glabrescente), amarela. Flores do disco 6-7 mm compr.; corola ca. $4 \mathrm{~mm}$ compr. (tubo ca. $0,5 \mathrm{~mm}$ compr.), amarela; anteras ca. $2,5 \mathrm{~mm}$ compr., enegrecidas, apêndice do conectivo ca. 0,5 mm compr., ovado, amarelo, ápice agudo, apêndice basal sagitado, filetes amarelos; estilete ca. $4 \mathrm{~mm}$ compr., amarelo, ramos do estilete ca. $1 \mathrm{~mm}$ compr., ápice agudo, pubescente. Cipselas imaturas 2,5-3 $\mathrm{mm}$ compr., oblanceoloides, enegrecidas, seríceas próximo ao ápice, levemente estipitadas, carpopódio inconspícuo; pápus de escamas, fusionadas na base ou livres, até ca. $1 \mathrm{~mm}$ compr., com 1 ou 2 aristas de 2-2,5 mm compr., pubescentes.

Endêmica do Brasil, em Minas Gerais e São Paulo (Magenta \& Pirani 2014), sendo aqui registrada pela primeira vez para o estado da Bahia. G5: cerrado. Encontrada com flores e frutos em maio.

Material examinado - Jacaraci, $14^{\circ} 52^{\prime} 26^{\prime \prime} \mathrm{S}, 4^{\circ} 29^{\prime} 38^{\prime \prime} \mathrm{W}$, 1117 m s.n.m., maio 2013, M. Alves et al. 187 (ALCB, HUEFS).

Aldama nudibasilaris é reconhecida por possuir brácteas involucrais subiguais e folhas fortemente discolores, lanceoladas a estreito-elípticas, com face adaxial vilosa e abaxial tomentosa.

2.7. Aldama oblongifolia (Gardner) E.E.Schill. \& Panero, Bot. J. Linn. Soc. 167(3): 324. 2011. Viguiera oblongifolia Gardner, London J. Bot. 7: 402. 1848.

Figura 6.

Subarbusto ca. $0,6 \mathrm{~m}$ alt.; ramo cilíndrico, estriado, estrigoso. Folhas opostas, às vezes as apicais alternas; pecíolo 0,1-0,6 cm compr.; lâmina 3,1-6,2 × 1-2,7 cm, cartácea, discolor, estreito-elíptica ou elíptica, ápice agudo, mucronado, margem inteira ou denteada, base arredondada, estrigosa em ambas as faces. Capítulos solitários, terminais, ca. $0,9 \times 1,3 \mathrm{~cm}$, radiados; pedúnculo ca. $28,6 \mathrm{~cm}$ compr., flexuoso; invólucro campanulado, brácteas involucrais gradativamente maiores, $16-18$, em 3 ou 4 séries, as mais externas 3-4 × 2-2,5 mm, as mais internas 9-10 $\times$ 1,5-2,5 mm, lanceoladas ou ovadas, ápice agudo ou acuminado, margem inteira, ciliada, verdes; receptáculo convexo, páleas 8-10 × 2-3 $\mathrm{mm}$, lanceoladas, conduplicadas, persistentes, geralmente carenadas, ápice acuminado, margem inteira, pubescentes na face abaxial. Flores ca. 43. Flores do raio ca. 8, 17-19 mm compr.; corola 12,5-14 mm compr. (tubo 1-1,5 mm compr.). Flores do disco 8-9,5 mm compr.; corola 4-4,5 mm compr. (tubo ca. $1 \mathrm{~mm}$ compr., glabrescente), amarela; anteras ca. $3 \mathrm{~mm}$ compr., apêndice do conectivo ca. 0,5 $\mathrm{mm}$ compr., ovado, amarelo, ápice agudo, apêndice basal sagitado, filetes amarelos; estilete ca. $5 \mathrm{~mm}$ compr., amarelo, ramos do estilete ca. $1 \mathrm{~mm}$ compr., ápice agudo, pubescente. Cipselas imaturas ca. $5 \mathrm{~mm}$ compr., oblanceoloides, carpopódio inconspícuo; pápus de escamas fundidas até $1 \mathrm{~mm}$ compr., com 1 ou 2 aristas de até $2,5 \mathrm{~mm}$ compr.

Endêmica do Brasil, com registros nas Regiões Norte, Nordeste, Centro-oeste e Sudeste (Magenta \& Pirani 2014), contudo o primeiro registro para o estado da Bahia foi feito apenas recentemente (Alves et al. 2015). G5: cerrado. Encontrada com flores e frutos em janeiro.

Material examinado - Licínio de Almeida, 1441'52"S, 42³3'33"W, 1.023 m s.n.m., jan. 2013, H.A. Ogasawara et al. 329 (ALCB).

Aldama oblongifolia é reconhecida pelos pedúnculos longos e flexuosos. O espécime encontrado na Bahia apresentou um capítulo solitário, porém, em outros estados, a espécie apresenta capitulescências.

\subsection{Aldama robusta (Gardner) E.E.Schill. \& Panero,} Bot. J. Linn. Soc. 167(3): 324. 2011. Viguiera robusta Gardner, London J. Bot. 7: 403. 1848.

Figura 6; Baker (1884: prancha 67).

Subarbusto ca. $1 \mathrm{~m}$ alt.; ramos cilíndricos, estriados, tomentosos. Folhas alternas, sésseis; lâmina $1,8-7,9 \times 1-1,8 \mathrm{~cm}$, coriácea, discolor, elíptica ou oblonga, ápice agudo, margem inteira, crenada ou serreada, base cuneada, face adaxial estrigosa ou setosa, às vezes tomentosa, a abaxial tomentosa, glandular. Capítulos em cimeiras racemosas, 0,6-1 $\times$ 0,9-1,4 cm, radiados; pedúnculo 0,1-2,1 cm compr., ereto, bractéolas 5-7 × ca. $2 \mathrm{~mm}$, ápice agudo, margem inteira, face adaxial estrigosa, a abaxial tomentosa; invólucro subgloboso ou campanulado, brácteas involucrais gradativamente maiores, ca. 39 , em 3 ou 4 séries, as mais externas ca. $4 \times 2 \mathrm{~mm}$, as mais internas ca. $6 \times 2,5 \mathrm{~mm}$, ovadas, ápice agudo, mucronado, margem inteira, ciliada, verdes, estrigosas ou setosas, às vezes só no ápice; receptáculo convexo, páleas 5-6 $\times 1,5-2 \mathrm{~mm}$, estreito-oblongas, glabras, às vezes pubescentes, conduplicadas, persistentes, carenadas, ápice arredondado, margem inteira. Flores ca. 124. 
Flores do raio 9-10 $\mathrm{mm}$ compr.; corola 6-7 mm compr. (tubo $2 \mathrm{~mm}$ compr., glabrescente), amarela. Flores do disco 6-8 $\mathrm{mm}$ compr.; corola 4-5 $\mathrm{mm}$ compr. (tubo ca. $1 \mathrm{~mm}$ compr.), amarela; anteras ca. 3 $\mathrm{mm}$ compr., apêndice do conectivo ca. $0,5 \mathrm{~mm}$ compr., ovado, glandular, ápice agudo, apêndice basal sagitado, filetes amarelos; estilete ca. $4 \mathrm{~mm}$ compr., amarelo, ramos do estilete ca. $1 \mathrm{~mm}$ compr., ápice agudo, pubescente. Cipselas imaturas ca. $3 \mathrm{~mm}$ compr., oblanceoloides, castanhas ou enegrecidas, serícias, carpopódio inconspícuo; pápus de escamas fusionadas na base até ca. 1,5 mm compr., com 1 arista de até 2 mm compr., pubescente.

Endêmica do Brasil, ocorrendo em todas as Regiões (Magenta \& Pirani 2014). E3, F3, G3: cerrado. Encontrada com flores e frutos de abril a julho.

Material selecionado - Barreiras, jul. 1983, M.L. Guedes 804 (ALCB); Cocos, $14^{\circ} 4^{\prime} 8^{\prime \prime S}$, 4429'47"W, 670 m s.n.m., abr. 2001,

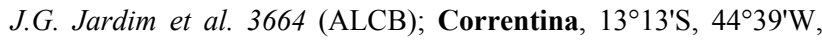
600 m s.n.m, abr. 1980, R.M. Harley et al. 21911 (RB); Jaborandi, $13^{\circ} 34^{\prime} 01^{\prime \prime S}, 44^{\circ} 30^{\prime} 33^{\prime \prime W}, 680$ m s.n.m, abr. 2001, J.G. Jardim et al. 3676 (ALCB).

Aldama robusta assemelha-se a $A$. veredensis, contudo podemos diferenciá-las pela lâmina foliar coriácea (vs. cartácea em $A$. veredensis) e a face abaxial tomentosa (vs. estrigosa).

2.9. Aldama veredensis (Magenta \& Pirani) E.E.Schill. \& Panero, Bot. J. Linn. Soc. 167(3): 325. 2011. Viguiera veredensis Magenta \& Pirani, Rodriguésia 61(1): 6. 2010.

Figura 6.

Subarbusto ca. $1 \mathrm{~m}$ alt.; ramos cilíndricos, estriados, estrigosos. Folhas opostas, as apicais alternas, sésseis ou curto-pecioladas (pecíolo até $1 \mathrm{~mm}$ compr.); lâmina 1,8-4 ×0,8-1,5 cm, cartácea, discolor, elíptica ou estreito-elíptica, ápice agudo, denteada na parte apical, base cuneada ou séssil, face adaxial estrigosa, a abaxial estrigosa, glandulosa. Capitulescências em cimeiras racemosas; pedúnculo 1,1-4,1 cm compr., bractéolas 4-6 × 1-2 mm compr., ápice agudo, margem inteira, verdes, estrigosas. Capítulos 0,9-1,2 $\times 1-1,7 \mathrm{~cm}$, radiados; invólucro subgloboso ou campanulado, brácteas involucrais gradativamente maiores, $17-20$, em 3 ou 4 séries, as mais externas ca. $3 \times 1,5-2 \mathrm{~mm}$, as mais internas 5-6 $\times$ 2-2,5 mm, lanceoladas ou ovadas, ápice agudo, mucronado, margem inteira, ciliada, verdes, estrigosas; receptáculo convexo, páleas 6-7 × 1-2 mm, estreitooblongas, conduplicadas, persistentes, carenadas, ápice truncado, eroso, margem inteira. Flores 47-63. Flores do raio 6-12, 14-15,5 mm compr.; corola 9,5-11 mm compr. (tubo 1-2 mm compr.), amarela. Flores do disco 7-9 mm compr.; corola 4-6 mm compr. (tubo ca. $1 \mathrm{~mm}$ compr.), amarela; anteras ca. $3 \mathrm{~mm}$ compr., apêndice do conectivo ca. $0,8 \mathrm{~mm}$ compr., ovado, ápice agudo, apêndice basal sagitado, filetes amarelos; estilete 5-6 mm compr., amarelo, ramos do estilete ca. $2 \mathrm{~mm}$ compr., ápice agudo, pubescente. Cipselas ca.

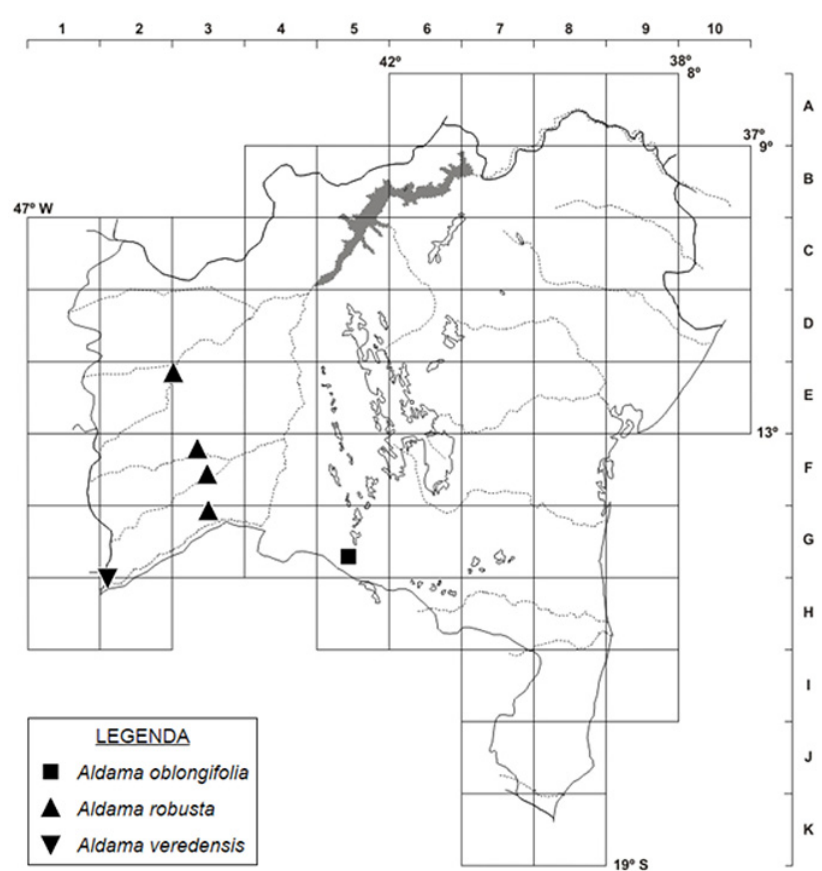

Figura 6. Mapa de distribuição geográfica de Aldama oblongifolia, A. robusta e $A$. veredensis no estado da Bahia.

3,5-4 mm compr., oblanceoloides, enegrecidas, setosas, carpopódio inconspícuo; pápus de escamas fusionadas na base até $2 \mathrm{~mm}$ compr., com 1 arista de até $2,5 \mathrm{~mm}$ compr., pubescente.

Endêmica do Brasil, nos estados de Minas Gerais e Bahia (Magenta 2006). G2: cerrado. Encontrada com flores e frutos em maio.

Material examinado - Cocos, $14^{\circ} 59^{\prime} 17^{\prime \prime} \mathrm{S}, 45^{\circ} 53^{\prime} 39^{\prime \prime} \mathrm{W}, 730 \mathrm{~m}$ s.n.m., maio 2001, R.C. Mendonça et al. 4338 (RB).

Há poucos registros desta espécie, um isolado no Norte de Minas Gerais e outro na Bahia (Magenta 2006). Assemelha-se a Aldama robusta (ver comentários naquela espécie).

\section{Ambrosia L.}

Ervas anuais ou perenes, ou arbustos. Folhas opostas ou alternas com as basais opostas; lâmina lobada, deltada ou ovada. Capítulos discoides, unissexuados, os femininos solitários ou agrupados na base de uma capitulescência espiciforme de capítulos funcionalmente masculinos; brácteas involucrais nos capítulos femininos completamente fundidas, às vezes formando processos espinhosos, achatadas ou cilíndricas, emergentes ou vestigiais, raramente ausentes, nos masculinos conatas em forma de funil, cúpula ou disco, com lobos proeminentes; receptáculo paleáceo nos capítulos masculinos e epaleáceo nos femininos. Flores femininas 1-7, sem perianto; as funcionalmente masculinas com corola tubulosa, hialina; anteras ecaudadas. Cipselas ovoides, obovoides ou elipsoides, glabras; pápus ausente.

Ambrosia é caracterizado por possuir no mesmo indivíduo capítulos masculinos com receptáculos paleáceos e capítulos femininos, geralmente unifloros e 

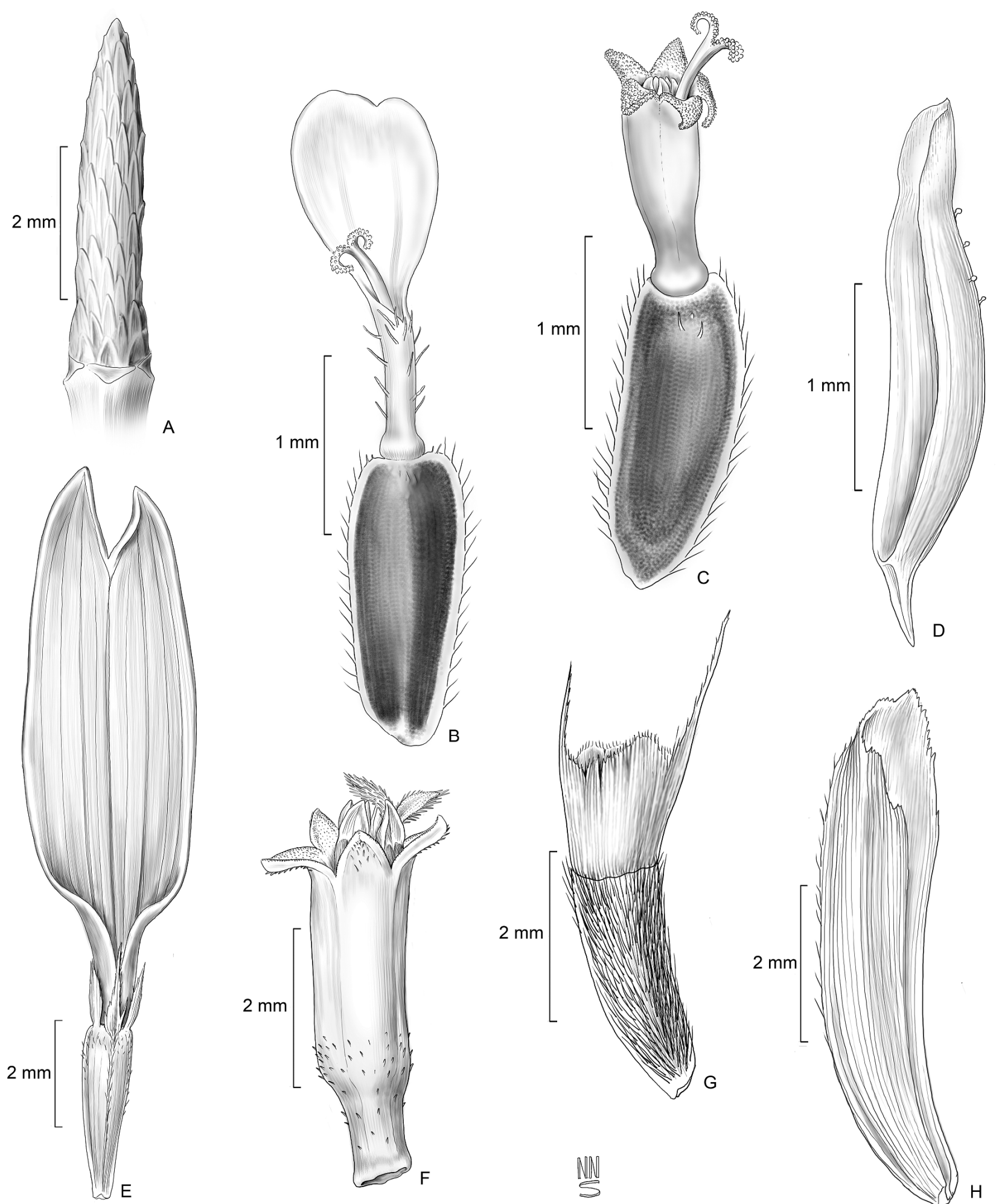

Figura 7. A-D. Acmella uliginosa: A- receptáculo cônico; B- flor do raio; C- flor do disco; D- pálea. E-H. Aldama bracteata: E- flor do raio neutra; F- corola da flor do disco; G- cipsela com pápus; H- pálea. (A-D- Alves 166; E-H- Alves 176).

epaleáceos (Panero 2007). O gênero possui aproximadamente 30 espécies, distribuídas no continente americano e introduzidas em outros continentes (Panero 2007). Para o Brasil, são citadas oito espécies (Nakajima et al. 2015) e, no estado da Bahia, foram reconhecidas três.

\section{Chave para as espécies}

1. Capítulos femininos com invólucro elipsoide, sem projeções na maturidade 3.3. A. polystachya

1'. Capítulos femininos com invólucro obovoide, com projeções cônicas apicais na maturidade.

2. Folhas com lobos pinatipartidos (bipinados) ....... 
2'. Folhas com lobos inteiros a pinatífidos (simplicinados) 3.2. A. microcephala

3.1. Ambrosia artemisiifolia L., Sp. P1. 2: 988.1753. = Ambrosia elatior L., Sp. P1. 2: 987. 1753.

Figura 8.

Nomes populares: artemísia-verdadeira, artemísia, artemija, ambrosia-americana, artemísia-do-campo.

Subarbusto ou arbusto $0,3-1 \mathrm{~m}$ alt.; ramos cilíndricos ou compressos, estriados, vilosos ou tomentosos. Folhas alternas, raramente opostas na base; pecíolo 0,6-1,9 cm compr.; lâmina 2,2-4,5 × 1,2-4,6 cm, membranácea, levemente discolor ou discolor, 3-7-lobada (lobos pinatipartidos), ápice mucronado, margem inteira, base atenuada ou decorrente, face adaxial estrigosa ou setosa, a abaxial vilosa ou tomentosa, glandulosas. Capítulos masculinos solitários, ao longo da espiga, raramente agrupados no ápice, curto-pedunculados (pedúnculo até $1 \mathrm{~mm}$ compr.); invólucro ca. $2 \times 1-2,5 \mathrm{~mm}$, campanulado, glabrescente ou setoso, verde, 5 lobos com ápice arredondado ou agudo; páleas ca. $2 \mathrm{~mm}$ compr., lineares ou filiformes. Flores 6-20, 1-2 mm compr.; ovário inconspícuo; anteras ca. $1 \mathrm{~mm}$ compr., alvas, apêndice do conectivo ca. 0,2 mm compr., ovado, ápice agudo, alvo, apêndice basal arredondado, filetes alvos. Capítulos femininos unifloros, agrupados na base da espiga, sésseis, brácteas foliáceas, 3-10 × 1-2 mm, oblanceoladas ou lineares, ápice acuminado, margem inteira, setosas, verdes; invólucro ca. $3 \times 1,5-2 \mathrm{~mm}$, obovoide, com projeções cônicas no ápice quando maduro, verde; Flores com estilete ca. $2 \mathrm{~mm}$ compr., castanho ou amarelo, ramos do estilete ca. 1,2 $\mathrm{mm}$ compr., ápice obtuso, pubescente. Cipselas ca. $2 \mathrm{~mm}$ compr., obovoides, enegrecidas, glabras, carpopódio inconspícuo.

América e África do Sul (Tropicos 2015); no Brasil, ocorre em quase todas as Regiões, exceto no CentroOeste (Nakajima et al. 2015). D5, D6, D7, E6, E8, E9, F8, F9, J8: áreas antropizadas. Encontrada com flores e frutos durante todo o ano.

Material selecionado - Barra do Mendes, $11^{\circ} 48^{\prime} 44^{\prime \prime} \mathrm{S}$, 425'24"W, 720 m s.n.m., dez. 2009, E. Melo et al. 6826 (ALCB, HUEFS); Cachoeira, $39^{\circ} 05^{\prime} \mathrm{S}, 12^{\circ} 32^{\prime} \mathrm{W}, 40-120 \mathrm{~m}$ s.n.m., jul.-set. 1980, Grupo Pedra do Cavalo 360 (ALCB, HUEFS); Camaçari, out. 1996, E. Saar 50 (ALCB); Dias d'Ávila, dez. 1971, W. Santana s.n. (ALCB 26717); Irecê, $11^{\circ} 48^{\prime} 44^{\prime \prime S}, 42^{\circ} 05^{\prime} 24^{\prime \prime} \mathrm{W}, 159$ m s.n.m., out. 2009, M.L. Guedes et al. 16096 (ALCB, HUEFS); Feira de Santana, $12^{\circ} 15^{\prime} \mathrm{S}, 38^{\circ} 58^{\prime} \mathrm{W}$, maio 1984, Lemos et al. 64 (HUEFS); Jacobina, $11^{\circ} 01^{\prime} 07^{\prime \prime S}, 40^{\circ} 32^{\prime} 43^{\prime \prime} \mathrm{W}, 632$ m s.n.m., jul. 1996, H.P. Bautista et al. PCD 3457 (ALCB, HUEFS); Lençóis, out. 1996, D.J.N. Hind \& L. Funch PCD 3789 (ALCB, HUEFS); Mirangaba, $11^{\circ} 02^{\prime} \mathrm{S}, 40^{\circ} 37^{\prime} \mathrm{W}$, set. 1981, R.P. Orlandi 483 (RB); Morro do Chapéu, $11^{\circ} 38^{\prime} 18^{\prime \prime} \mathrm{S}, 40^{\circ} 56^{\prime} 56^{\prime \prime} \mathrm{W}, 684$ m s.n.m., jun. 2012, E. Melo et al. 11144 (HUEFS); Mutuípe, 13²1'S, 39³0'W, nov. 2006, M.P. Leite \& C.S. Santos 32 (HUEFS); Prado, $17^{\circ} 06^{\prime} \mathrm{S}, 39^{\circ} 11^{\prime} \mathrm{W}$, jan. 1977, R.M. Harley et al. 18070 (RB); Salvador, 1258"S, 38³0"W, nov. 2006, S.T.C. Lima 57 (ALCB).
Ambrosia artemisiifolia e A. elatior foram publicadas na mesma obra e Baker (1884) estabeleceu a prioridade pelo primeiro nome ao sinonimizar as duas espécies. Em floras e monografias, elas vêm sendo consideradas sinônimos, juntamente com $A$. maritima L. e A. peruviana Willd. (Tropicos 2015). Neste trabalho, também reconhecemos uma única espécie.

3.2. Ambrosia microcephala DC., Prodr. 5: 527. 1836.

Figura 8.

Subarbusto ou arbusto ca. 0,2-1 m alt.; ramos cilíndricos, estriados, vilosos ou tomentosos. Folhas alternas, raramente opostas na base; pecíolo $(0,6) 0,9$ $2,7 \mathrm{~cm}$ compr.; lâmina 3,3-5,6 × 1,7-4,4 cm, membranácea, levemente discolor ou discolor, raramente inteira ou 3-7-lobada (lobos inteiros ou pinatífidos), ápice mucronado, margem inteira, base atenuada ou decorrente, face adaxial estrigosa ou setosa, a abaxial vilosa ou setosa, ambas glandulosas. Capítulos masculinos solitários, ao longo da espiga, raramente agrupados no ápice, curto-pedunculados (até $1 \mathrm{~mm}$ compr.); invólucro 1,5-2 $\times 2-2,5 \mathrm{~mm}$, campanulado, glabro a glabrescente, verde, 5 lobos com ápice arredondado ou agudo; páleas ca. $2 \mathrm{~mm}$ compr., filiformes. Flores 6-10, 1-2 mm compr.; ovário inconspícuo; anteras ca. $1 \mathrm{~mm}$ compr., alvas, apêndice do conectivo ca. 0,2 mm compr., ovado, ápice acuminado, alvo, apêndice basal arredondado, filetes alvos. Capítulos femininos unifloros, agrupados na base da espiga, sésseis; brácteas foliáceas 3-11 × 1-3,5 mm, oblanceoladas ou lineares, ápice agudo, margem inteira, setosas, verdes; invólucro 1,5-3 × 1-2 mm, obovoide, setoso próximo ao ápice, com projeções cônicas no ápice quando maduro, verde. Flores com estilete ca. 1,5 $\mathrm{mm}$ compr., castanho ou amarelo, ramos do estilete ca. 1 mm compr., ápice obtuso, pubescente. Cipselas ca. 2 $\mathrm{mm}$ compr., obovoides ou elipsoides, enegrecidas, glabras, carpopódio inconspícuo.

Registrada para Guiana Francesa, Suriname e Brasil (Tropicos 2015), nos estados do Norte e Nordeste (Nakajima et al. 2015). Não foi citada para a Bahia por Nakajima et. al. (2015), apesar de já ter sido registrada no estado por Baker (1884). E9, F8: áreas antropizadas. Encontrada com flores e frutos em julho.

Material selecionado - Igrapiúna, $13^{\circ} 54^{\prime} 19^{\prime \prime} \mathrm{S}, 39^{\circ} 12^{\prime} 28^{\prime \prime} \mathrm{W}$, 153 m s.n.m., jul. 2012, M.L. Guedes et al. 17223 (ALCB); Mata de São João, jul. 2002, E.V.S. Medeiros et al. 168 (RB).

Ambrosia microcephala é semelhante a $A$. artemisiifolia, distinguindo pelos lobos inteiros a pinatífidos (vs. lobos pinatipartidos, em $A$. artemisiifolia) e pelos pecíolos geralmente um pouco maiores, (0,6)0,9-2,7 (vs. 0,6-1,9). Baker (1884) foi o único que descreveu esta espécie depois da obra princeps, sendo ainda necessária a análise de mais espécimes em uma maior abrangência geográfica para uma melhor delimitação do táxon. 
3.3. Ambrosia polystachya DC., Prodr. 5: 526. 1836. Figura 8; Baker (1884: prancha 48).

Subarbusto ou arbusto ca. $1,5 \mathrm{~m}$ alt. Ramos cilíndricos, estriados, glabrescentes ou tomentosos. Folhas alternas, raramente opostas na base, pecíolo 0,3-2 cm compr., lâmina 4,7-10 × 2,6-3,7 cm compr., cartácea, fortemente discolor, 3-7-lobada (lobos inteiros ou pinatífidos), ápice acuminado, margem inteira ou serreada no lobo apical, base atenuada ou decorrente, face adaxial estrigosa, a abaxial tomentosa. Capítulos masculinos solitários, ao longo da espiga, curto-pedunculados (pedúnculo até $1 \mathrm{~mm}$ compr.); invólucro $1,5-2,5 \times 1,5-2,5 \mathrm{~mm}$, campanulado, glabrescente, às vezes glanduloso, verde, 5 lobos com ápice arredondado ou agudo; páleas ca. $1 \mathrm{~mm}$ compr., filiformes. Flores 5-10, 1,5-2 mm compr.; ovário inconspícuo; anteras ca. $1,1 \mathrm{~mm}$ compr., alvas, apêndice do conectivo ca. $0,1 \mathrm{~mm}$ compr., ovado, ápice agudo, alvo, apêndice basal arredondado, filetes alvos. Capítulos femininos unifloros, agrupados na base da espiga, sésseis; brácteas foliáceas 3-3,5 × 1-1,5 mm e estreito-elípticas ou elípticas ou 6-11 $\times$ ca. $1 \mathrm{~mm}$ e lineares ou lanceoladas, ápice obtuso ou agudo, margem inteira, verdes; invólucro 2,5-4 × 1-2 mm, elipsoide, sem projeções quando maduro, verde; estilete ca. 1,5 mm compr., castanho ou amarelo, ramos do estilete ca. $1 \mathrm{~mm}$ compr., ápice obtuso, pubescente. Cipselas ca. $3 \mathrm{~mm}$ compr., elipsoides, castanhas ou enegrecidas, glabras, carpopódio inconspícuo.

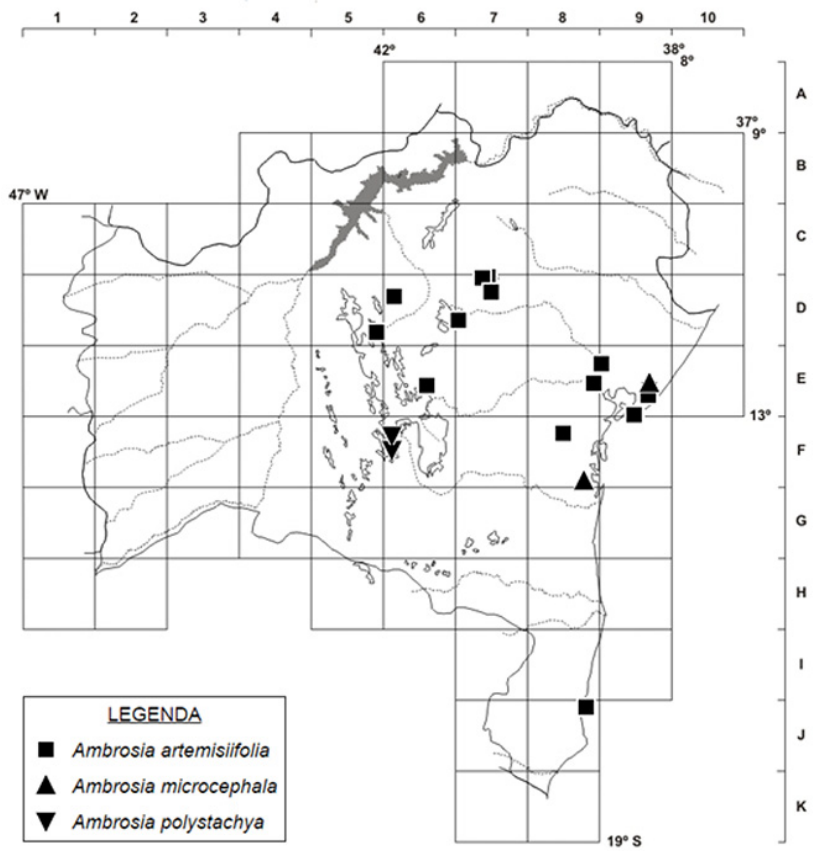

Figura 8. Mapa de distribuição geográfica de Ambrosia artemisiifolia, A. microcephala e A. polystachya no estado da Bahia.
Endêmica do Brasil, no Sul e Sudeste (Nakajima et al. 2015), sendo este o seu primeiro registro para o estado da Bahia. F6: áreas antropizadas. Encontrada com flores e frutos de janeiro a fevereiro.

Material examinado - Abaíra, $13^{\circ} 16^{\prime} \mathrm{S}, 41^{\circ} 53^{\prime} \mathrm{W}, 1300 \mathrm{~m}$ s.n.m., jan. 1992, D.J.N. Hind \& J.R. Pirani H 51334 (HUEFS); Rio de Contas, 1327'33"S, 4152'24", 1130 m s.n.m., fev. 1997, L. Passos et al. PCD 5037 (ALCB).

Diferencia-se das outras duas espécies de Ambrosia que ocorrem no estado, pelo invólucro dos capítulos femininos elipsoide, sem projeções no ápice (vs. obovoide com projeções cônicas no ápice), além da lâmina foliar fortemente discolor (vs. discolor). É geralmente confundida com Artemisia vulgaris L. (tribo Anthemideae), que também possui lâmina foliar lobada e fortemente discolor; contudo, distingue-se daquela espécie por possuir dois tipos de capítulo, funcionalmente masculinos e femininos (vs. um único tipo de capítulo com flores bissexuadas).

\section{Aspilia Thouars}

Ervas, subarbustos ou arbustos, anuais ou perenes. Folhas opostas, raramente alternas ou alternas e opostas; lâmina linear, linear-lanceolada, elíptica, elíptico-lanceolada, ovada, ovado-lanceolada, obovada, cordiforme, espatulada ou oblonga. Capítulos radiados, solitários ou em capitulescências umbeliformes ou corimbiformes, pedunculados; receptáculo plano, paleáceo; brácteas involucrais em 2-6 séries, elípticas, lanceoladas, linear-lanceoladas, oblongas, ovadas, obovadas ou ovado-lanceoladas. Flores do raio neutras, inseridas na base das brácteas involucrais internas; corola do raio verdadeira, amarela, raro alaranjada ou branca. Flores do disco bissexuadas; corola tubulosa, 5-laciniada, papilosa, amarela, raro alaranjada ou branca; anteras com apêndices basais sagitados; estilete piloso no ápice ou até o ponto de bifurcação, raramente abaixo deste, ramos papilosos. Cipselas oblanceoloides, obovoides ou elipsoides, pilosas, carpopódio cartilaginoso conspícuo; pápus coroniforme de escamas paleáceas constritas na base, com 1, 2, várias ou sem aristas.

Aspilia pode ser reconhecido por possuir flores do raio neutras e cipsela com uma cicatriz basal (Santos 2001). Possui cerca de 150 espécies, distribuídas no México, América Central, América do Sul e África (Santos 2001). No Brasil, são registradas 64 espécies com distribuição em todas as Regiões (Nakajima et al. 2015), 15 na Bahia.

\section{Chave para as espécies}

1. Brácteas involucrais subiguais, em 2 ou 3 séries (Figura $26 \mathrm{G}$ ).

2. Lâmina foliar com margem conspicuamente serreada; flores com corola alva 4.8. A. leucoglossa

2'. Lâmina foliar com margem inteira a levemente serreada; flores com corola amarela.

3. Brácteas involucrais em 3 séries, ápice geralmente reflexo 4.2. A. attenuata

3'. Brácteas involucrais em 2 séries, ápice ereto. 
4. Lâmina foliar linear ou lanceolada; brácteas involucrais com ápice caudado

4'. Lâmina foliar estreito-elíptica ou elíptica; brácteas involucrais com ápice agudo ou acuminado, raramente arredondado.

5. Erva ereta; páleas do receptáculo com ápice caudado

4.6. A. foliacea

5'. Erva prostrada, subarbusto ou arbusto ereto ou prostrado; páleas do receptáculo com ápice agudo.

6. Lâmina foliar inteira, revoluta, coriácea …………….............................. 4.14. A. subalpestris

6'. Lâmina foliar inteira ou levemente serreada, às vezes somente no $1 / 3$ apical ou $2 / 3$ apicais, plana, membranácea, cartácea ou subcoriácea.

7. Lâmina foliar e brácteas involucrais vilosas, nervações secundárias evidentes em ambas as faces

4.12. A. riedelii

7'. Lâmina foliar e brácteas involucrais estrigosas, às vezes estrigosas e esparso-setosas, nervações secundárias evidentes somente em uma das faces.

8. Capitulescências corimbiformes, raramente capítulos solitários; brácteas involucrais 7-9 .

8'. Capítulos solitários; brácteas involucrais 11-16.

4.3. A. bonplandiana

9. Erva prostrada; lâmina foliar séssil

4.10. A. montevidensis

9'. Subarbusto ereto ou prostrado; lâmina foliar subséssil (pecíolo $0,1-0,3 \mathrm{~mm}$ compr.)

4.11. A. prostrata

1'. Brácteas involucrais em 3-6 séries, as internas gradativamente maiores (Figura 26D).

10. Lâmina foliar linear ou estreito-elíptica.

11. Arbusto decumbente; lâmina foliar cartácea, margem serreada, plana

11'. Arbusto ereto; lâmina foliar coriácea, margem inteira, revoluta

4.5. A. floribunda

0'. Lâmina foliar lanceolada ou ovada.

12. Arbustos com ramos subescandentes; lâmina foliar com ambas as faces glabrescentes ou estrigosas nas nervações

4.15. A. subscandens

12'. Arbustos eretos; lâmina foliar com face adaxial estrigosa ou setosa e abaxial estrigosa, vilosa ou tomentosa.

13. Lâmina foliar com margem serreada nos $2 / 3$ apicais; folhas de tamanhos variados no mesmo ramo

13'. Lâmina foliar com margem inteira; folhas similares em tamanho no mesmo ramo.

14. Lâmina foliar 3-8 × 6-14,5 cm, lanceolada, face abaxial cinérea quando seca

14. Lamina foin $1,2-3,6 \times 0,3-0,8 \mathrm{~cm}$, lancolada a ovat face abaxi. 4.13. A. squarrosa

14'. Lâmina foliar $1,2-3,6 \times 0,3-0,8 \mathrm{~cm}$, lanceolada a ovada, face abaxial castanha quando seca.

4.1. A. almasensis

4.1. Aspilia almasensis D.J.N.Hind, Kew Bull. 48(2): 273. 1993.

Figura 9.

Arbusto 0,8-2 m alt.; ramos cilíndricos, seríceos ou tomentosos. Folhas opostas, sésseis ou subsésseis (pecíolo até $0,1 \mathrm{~mm}$ compr.); lâmina 1,2-3,6 × 0,3-0,8 $\mathrm{cm}$, coriácea, discolor, lanceolada ou ovada, ápice agudo, margem inteira, geralmente revoluta, base cuneada ou arredondada, face adaxial estrigosa ou setosa, a abaxial vilosa ou tomentosa, castanha quando seca. Capítulos solitários ou 2 ou 3, terminais, 0,9-1,7 $\times 0,7-1,2 \mathrm{~cm}$; pedúnculo $0,2-1,7 \mathrm{~cm}$ compr.; invólucro subcilíndrico ou campanulado, brácteas involucrais gradativamente maiores, ca. 28 , em 4 ou 5 séries, as mais externas $3-5 \times$ ca. $2 \mathrm{~mm}$, as mais internas 6-7 $\times$ 2-3 mm, lanceoladas ou ovadas, ápice agudo ou acuminado, margem inteira, às vezes ciliada, verdeclaras com ápice verde-escuro, estrigosas, geralmente apenas próximo ao ápice; páleas 9-10,5 × $2 \mathrm{~mm}$, lanceoladas, conduplicadas, persistentes, carenadas, ápice agudo ou acuminado, margem inteira. Flores 3639. Flores do raio $7-9,12-13 \mathrm{~mm}$ compr.; corola 10 $11 \mathrm{~mm}$ compr. (tubo ca. $2 \mathrm{~mm}$ compr.), amarela. Flores do disco 8-10 mm compr.; corola 4-5 $\mathrm{mm}$ compr. (tubo ca. $1 \mathrm{~mm}$ compr.), amarela; anteras ca. $3 \mathrm{~mm}$ compr., enegrecidas, apêndice do conectivo ca. $0,2 \mathrm{~mm}$ compr., ovado, amarelo, ápice agudo, filetes amarelos; estilete ca. $7 \mathrm{~mm}$ compr., amarelo, ramos do estilete ca. $1 \mathrm{~mm}$ compr., ápice agudo, pubescente. Cipselas ca. 6 $\mathrm{mm}$ compr., oblanceoloides, castanhas, cinza ou cinza com manchas castanhas, pubescente, carpopódio assimétrico; pápus ca. $0,5 \mathrm{~mm}$ compr., ápice eroso.

Endêmica do estado da Bahia (Nakajima et al. 2015). F5, F6, G7: campo rupestre. Encontrada com flores e frutos de outubro a janeiro.

Material selecionado - Abaíra, $13^{\circ} 18^{\prime} \mathrm{S}, 41^{\circ} 51^{\prime} \mathrm{W}, 1200$ 1300 m s.n.m., jan. 2014, W. Ganev 2833 (HUEFS); Caetité, $13^{\circ} 56^{\prime} 41^{\prime \prime S}, 42^{\circ} 33^{\prime 2} 24^{\prime \prime W}, 963$ m s.n.m., jan. 2008, J.B.F. Pastore et al. 2528 (HUEFS); Piatã, $13^{\circ} 13^{\prime} \mathrm{S}, 41^{\circ} 50^{\prime} \mathrm{W}, 1600-1700 \mathrm{~m}$ s.n.m., dez. 1991, R.M. Harley et al. H 50388 (HUEFS); Rio de Contas, $13^{\circ} 31^{\prime} 21^{\prime \prime S}, 41^{\circ} 53^{\prime} 20^{\prime \prime} \mathrm{W}, 1293$ m s.n.m., mar. 2004, R.M. Harley et al. 55088 A (HUEFS); Vitória da Conquista, $14^{\circ} 50^{\prime} \mathrm{S}$, 40² 'W, 900-1000 m s.n.m., out. 2013, L.C. Marinho et al. 521 (HUEFS).

Aspilia almasensis é similar a A. fruticosa Baker, citada para Minas Gerais e Rio de Janeiro (Nakajima et al. 2015), da qual se diferencia pelas brácteas involucrais gradativamente maiores (vs. de tamanhos 
similares), capítulos geralmente solitários (vs. (geralmente em dicásios) e pedúnculos geralmente maiores (10-20 mm vs. 5-15 mm) (Hind 1993). Pode ser confundida também com uma das formas de $A$. foliosa com folhas mais largas, da qual se diferencia pela face abaxial da lâmina vilosa ou tomentosa (vs. serícea) (Santos 2001).

4.2. Aspilia attenuata (Gardner) Baker in Martius \& Eichler, Fl. Bras. 6(3): 199. 1884. Viguiera attenuata Gardner, London J. Bot. 7: 400. 1848.

Figura 9.

Arbusto decumbente $1-1,5 \mathrm{~m}$ alt.; ramos cilíndricos, estriados, estrigosos. Folhas opostas, subsésseis (pecíolo 0,1-0,2 cm compr.); lâmina 4,6$10 \times 0,4-0,7 \mathrm{~cm}$, cartácea, discolor, linear ou lanceolada, ápice acuminado, margem inteira, revoluta, base cuneada, face adaxial estrigosa, a abaxial estrigosa, às vezes setosa nas nervações. Capitulescências corimbiformes; pedúnculo 0,1-1,2 $\mathrm{cm}$ compr., bractéola $10 \times 1,5 \mathrm{~mm}$, lanceolada, ápice acuminado, estrigosa. Capítulos $0,9-1,1 \times 0,4-0,9$ $\mathrm{cm}$; invólucro cilíndrico ou campanulado, brácteas involucrais subiguais, 14 ou 15 , em 3 séries, $6-12 \times$ 2-3,5 $\mathrm{mm}$, lanceoladas, ápice acuminado ou caudado, geralmente reflexo, margem inteira, verde-claras com ápice verde-escuro, estrigosas; páleas $8-10 \mathrm{~mm}$ compr., lanceoladas, persistentes, carenadas, com apêndice apical lanceolado, ápice acuminado, margem inteira, às vezes erosa próximo ao ápice, pubescente na parte apical. Flores 40-48. Flores do raio 5-7, 21-23 mm compr.; corola 18-20 $\mathrm{mm}$ compr. (tubo ca. $2 \mathrm{~mm}$ compr.), amarela. Flores do disco $7-$ $10 \mathrm{~mm}$ compr.; corola 5-6 mm compr. (tubo $1-1,5$ $\mathrm{mm}$ compr.), amarela; anteras ca. $3 \mathrm{~mm}$ compr., enegrecidas, apêndice do conectivo ca. $0,5 \mathrm{~mm}$ compr., triangular, glanduloso, amarelo, ápice agudo, filetes amarelos; estilete 6-7 $\mathrm{mm}$ compr., amarelo, ramos do estilete $2-2,5 \mathrm{~mm}$ compr., ápice agudo, pubescente. Cipselas imaturas $3-3,5 \mathrm{~mm}$ compr., oblanceoloides, castanhas, pubescentes, carpopódio inconspícuo; pápus ca. $1 \mathrm{~mm}$ compr., ápice eroso, às vezes com 1 ou 2 aristas de $1-1,5 \mathrm{~mm}$ compr., pubescentes.

Endêmica do Brasil, com registros para todas as Regiões (Nakajima et al. 2015), mas este é o primeiro para o estado da Bahia. C2: cerrado. Encontrada com flores e frutos em março.

Material examinado - Formosa do Rio Preto, $10^{\circ} 51^{\prime} 39^{\prime \prime} \mathrm{S}$, 458'53"W, 640 m s.n.m., mar. 2000, F. França et al. 3291 (ALCB).

Aspilia attenuata é similar a A. floribunda pelo hábito arbustivo decumbente e a presença de capitulescências, mas pode ser diferenciada pelas brácteas involucrais subiguais, em 3 séries, lanceoladas, com ápice geralmente reflexo ( $v s$. brácteas involucrais gradativamente maiores, em 5 ou 6 séries, ovadas a oblongas, com ápice sempre ereto) e pápus coroniforme com aristas (vs. sem aristas).
4.3. Aspilia bonplandiana (Gardner) S.F.Blake, Contr. U.S. Natl. Herb. 20: 421. 1921. Viguiera bonplandiana Gardner, London J. Bot. 7: 399. 1848.

Figura 9.

Arbusto ca. 0,5 m alt.; ramos cilíndricos, estriados, estrigosos. Folhas opostas, sésseis ou curto-pecioladas (pecíolo até $0,1 \mathrm{~cm}$ compr.); lâmina 2,9-3,8 × 0,7-1,8 $\mathrm{cm}$, membranácea ou cartácea, discolor, elíptica, ápice agudo, margem inteira ou levemente serreada, base cuneada, estrigosa, esparso-setosa em ambas as faces. Capítulos $1-3$, terminais, $0,7-0,9 \times 0,7-0,8 \mathrm{~cm}$; pedúnculo $0,6-3,3 \mathrm{~cm}$; invólucro campanulado, brácteas involucrais subiguais, 7-9, em 2 séries, 7-11 $\times 2,5-3 \mathrm{~mm}$, lanceoladas ou ovadas, ápice acuminado, margem inteira, verdes, estrigosas ou setosas; páleas 5$6 \times$ ca. $2 \mathrm{~mm}$ compr., lanceoladas ou estreito-oblongas, conduplicadas, persistentes, geralmente carenadas, ápice agudo, margem inteira, erosa na parte apical, ciliada, pubescentes na face abaxial, às vezes glandulosas. Flores 36-51. Flores do raio 5-7, 13-16 $\mathrm{mm}$ compr.; corola 11-13 mm compr. (tubo 1-2 mm compr., com tricomas esparsos), amarela. Flores do disco 6-8 mm compr.; corola 3-5 $\mathrm{mm}$ compr. (tubo ca. $1 \mathrm{~mm}$ compr.), amarela; anteras ca. $2 \mathrm{~mm}$ compr., enegrecidas, apêndice do conectivo ca. $0,3 \mathrm{~mm}$ compr., triangular, amarelo, ápice agudo, filetes amarelos; estilete ca. $4 \mathrm{~mm}$ compr., amarelo, ramos do estilete ca. $1 \mathrm{~mm}$ compr., ápice agudo, pubescente. Cipselas ca. 4 $\mathrm{mm}$ compr., oblanceoloides, castanhas com manchas castanho-escuras, pubescentes, carpopódio assimétrico; pápus ca. $1 \mathrm{~mm}$ compr., com 2 aristas de até $1 \mathrm{~mm}$ compr.

Endêmica do Brasil, com registro somente para o Nordeste (Nakajima et al. 2015). B8, B9: caatinga. Encontrada com flores e frutos em janeiro.

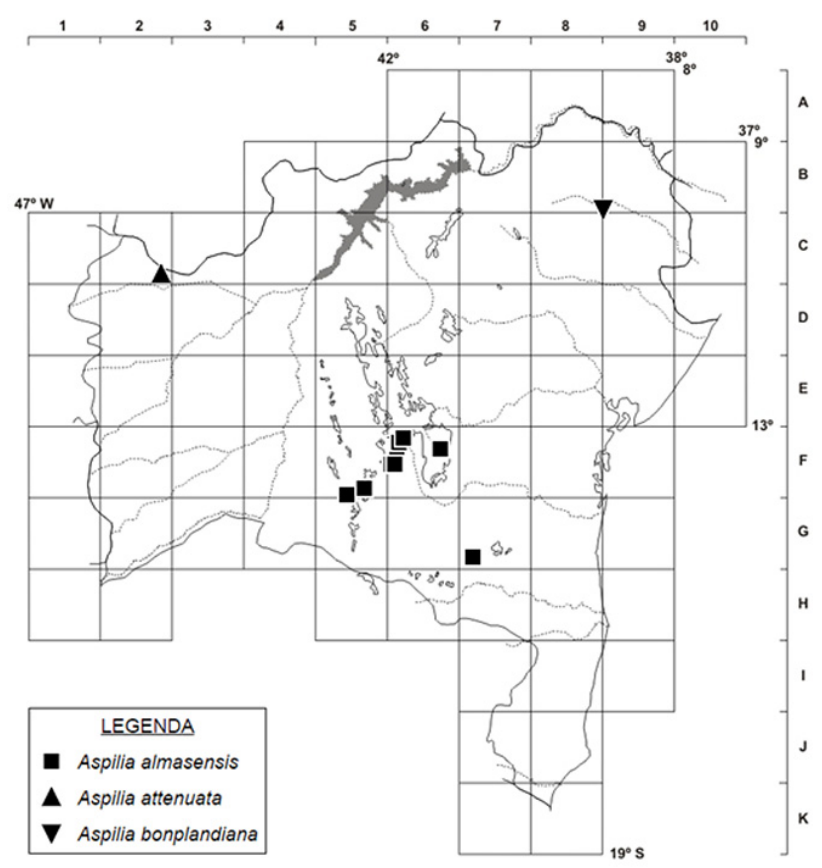

Figura 9. Mapa de distribuição geográfica de Aspilia almasensis, A. attenuata e A.bonplandiana no estado da Bahia. 
Material examinado - Canudos, $09^{\circ} 56^{\prime} 34^{\prime \prime} \mathrm{S}, 38^{\circ} 59^{\prime} 17^{\prime \prime} \mathrm{W}$, jan. 2002, M.S. Castro \& C.M. Pigozzo s.n. (ALCB 66355).

Aspilia bonplandiana possui brácteas involucrais com ápice acuminado, assemelhando-se a $A$. martii, da qual se distingue pela lâmina foliar elíptica $(2,9-3,8 \times$ $0,7-1,8 \mathrm{~cm})$ vs. linear a lanceolada $(4-7,3 \times 0,2-1 \mathrm{~cm})$.

\subsection{Aspilia egleri J.U.Santos, Revista Brasil. Bot. 19(1): 99. 1996.}

Figuras 10 e $26 \mathrm{C}$.

Arbusto 1-1,5 $\mathrm{m}$ alt., ereto; ramos cilíndricos, estriados, glabrescentes, estrigosos ou vilosos. Folhas opostas, curto-pecioladas (pecíolo até $0,2 \mathrm{~cm}$ compr.); lâmina 2-4,4 × 0,9-2,3 cm, cartácea ou subcoriácea, discolor, lanceolada ou ovada, ápice agudo, margem serreada nos 2/3 apicais, às vezes revoluta, base arredondada ou cuneada, face adaxial estrigosa, a abaxial estrigosa ou vilosa. Capítulos 1-3, terminais ou axilares, curto-pedunculados (pedúnculo até $0,3 \mathrm{~cm}$ compr.), $0,8-1 \times 0,5-0,8 \mathrm{~cm}$; invólucro cilíndrico, brácteas involucrais gradativamente maiores, 15 ou 16 , em 4-6 séries, as mais externas 3-5 × 1,5-2 mm, ovadas, as mais internas $6,5-8 \times$ ca. $2 \mathrm{~mm}$, oblongas ou estreito-oblongas, às vezes similares às páleas em textura, ápice agudo, reflexo, margem inteira, verdeamareladas com ápice verde-escuro, estrigoso; páleas 8 $10,5 \times 2-2,5 \mathrm{~mm}$, lanceoladas, conduplicadas, persistentes, geralmente carenadas, apêndice apical ovado, ápice agudo, estrigoso, margem inteira. Flores 19-29. Flores do raio 5-7, 8-10 mm compr.; corola 6-9 mm compr. (tubo 1,5-3 mm compr.), amarela. Flores do disco 6-7,5 mm compr.; corola 4-5 mm compr. (tubo 0,5-1 mm compr.), amarela; anteras ca. $2 \mathrm{~mm}$ compr., enegrecidas, apêndice do conectivo ca. 0,2 mm compr., ovado, enegrecido, ápice obtuso, filetes amarelos; estilete ca. 6,5 mm compr., amarelo, ramos do estilete ca. 1,5 mm compr., ápice agudo, pubescente. Cipselas imaturas 3-3,5 mm compr., oblanceoloides, castanhas ou enegrecidas, pubescentes, carpopódio inconspícuo; pápus ca. $0,5 \mathrm{~mm}$ compr., ápice eroso.

Era conhecida somente do material tipo de Minas Gerais, mas recentemente foi registrada para o município de Licínio de Almeida, no sudoeste da Bahia (Alves et al. 2015). G5: cerrado. Encontrada com flores e frutos em maio.

Material examinado - Licínio de Almeida, 14³0'15"S 42 ${ }^{\circ} 13^{\prime} 19^{\prime \prime W}, 805$ m s.n.m., maio 2012, N. Roque et al. 3530 (ALCB).

Material adicional examinado - BRASIL. MINAS GERAIS: Diamantina, jan. 1947, W. Engler s.n. (holótipo RB 59679).

Dentre as espécies de arbustos eretos do gênero que ocorrem na Bahia, Aspilia egleri pode ser reconhecida por possuir margem da lâmina foliar serreada nos $2 / 3$ apicais (vs. inteira) e folhas de tamanhos variados (vs. similares) no mesmo ramo.

4.5. Aspilia floribunda (Gardner) Baker in Martius \& Eichler, Fl. Bras. 6(3): 198. 1884. Viguiera floribunda Gardner, London J. Bot. 7: 401. 1848.

Figuras 10 e 26D.
Arbusto ca. 1,5 $\mathrm{m}$ alt., decumbente; ramos cilíndricos, estriados, estrigosos ou vilosos. Folhas opostas, curto-pecioladas (pecíolo até 0,2-0,8 cm compr.); lâmina 3,4-15,2 × 0,4-3,9 cm, cartácea, discolor, estreito-elíptica ou linear, ápice agudo ou acuminado, margem serreada, base atenuada ou cuneada, estrigosa em ambas as faces. Capitulescências em corimbos de capítulos terminais; pedúnculo 0,2-4 cm compr. Capítulos 0,8-1,2 × 0,7$1,2 \mathrm{~cm}$; invólucro cilíndrico ou subgloboso, brácteas involucrais gradativamente maiores, 16-22, em 5 ou 6 séries, as mais externas 3-5 × 1,5-2 mm, ovadas, as mais internas $6-8 \times$ ca. $2 \mathrm{~mm}$, ovadas ou oblongas, às vezes similares às páleas em textura, ápice acuminado, ereto, margem inteira, ciliada, verde-claras, com ápice verde-escuros; páleas 7,5-9 × $2 \mathrm{~mm}$, lanceoladas, conduplicadas, persistentes, carenadas, apêndice apical ovado, ciliado, ápice agudo, margem inteira. Flores 40-44. Flores do raio 7-10, 14-19 mm compr.; corola 10,5-13 mm compr. (tubo 2-3 mm compr.), amarela. Flores do disco 5-8 mm compr.; corola 4-5,5 $\mathrm{mm}$ compr. (tubo ca. $2 \mathrm{~mm}$ compr.), amarela; anteras ca. 2 mm compr., enegrecidas, apêndice do conectivo ca. 0,3 $\mathrm{mm}$ compr., triangular, glanduloso, amarelo, ápice obtuso, filetes amarelos; estilete 4,5-5 $\mathrm{mm}$ compr., amarelo, ramos do estilete ca. 1,7 mm compr., ápice agudo, pubescente. Cipselas ca. $5 \mathrm{~mm}$ compr., obovoides, enegrecidas, setosas, indumento alvo, carpopódio assimétrico; pápus ca. 0,5 $\mathrm{mm}$ compr.

Conta com registros para todas as Regiões, porém no Nordeste só era conhecida para o Piauí, sendo recentemente registrada no estado da Bahia (Alves et al. 2015). G5: cerrado. Encontrada com flores e frutos em fevereiro.

Material selecionado - Licínio de Almeida, 19³9'51"S, 42³0'20"W, 1035 m s.n.m., fev. 2012, M. Alves et al. 71 (ALCB).

Aspilia floribunda pode ser confundida com $A$. attenuata, da qual se diferencia pelas brácteas involucrais gradativamente maiores (vs. subiguais), em 5 ou 6 séries (vs. em 3), ovadas a oblongas (vs. laceoladas), com ápice sempre ereto (vs. geralmente reflexo) e pápus coroniformes sem aristas (vs. com aristas).

\subsection{Aspilia foliacea (Spreng.) Baker in Martius \&} Eichler, Fl. Bras. 6(3): 193. 1884. Viguiera foliacea Spreng., Syst. Veg. 3: 616. 1826.

Figura 10; Baker (1884: prancha 63).

Erva ca. 0,4 $\mathrm{m}$ alt., ereta; ramos cilíndricos, estriados, vilosos. Folhas opostas, sésseis a curtopecioladas (pecíolo até $0,3 \mathrm{~cm}$ compr.); lâmina 2,6-6,5 $\times$ 0,8-2,7 cm compr., cartácea, levemente discolor, estreito-elíptica a elíptica, ápice agudo, margem inteira a serreada, atenuada a cuneada, setosa a vilosa em ambas as faces. Capítulos solitários, terminais, 1,2-1,7 $\times$ 1-1,5 cm; pedúnculo 3,1-12,5 cm compr.; invólucro campanulado, brácteas involucrais subiguais, ca. 7, em 2 séries, 0,9-2 × 0,2-0,5 mm, lanceoladas ou ovadas, ápice agudo, margem inteira, verdes, vilosas ou 
setosas; páleas 8,5-11 × 1,5-2 mm, lanceoladas, conduplicadas, persistentes, geralmente com carena levemente pubescente, ápice caudado, margem inteira. Flores 36-49. Flores do raio 5-10, 20-27 mm compr.; corola $18-25 \mathrm{~mm}$ compr. (tubo $2-3,5 \mathrm{~mm}$ compr.), amarela. Flores do disco 7-9 mm compr.; corola 5-6 mm compr. (tubo 1-2 mm compr.), amarela; anteras ca. $3 \mathrm{~mm}$ compr., enegrecidas, apêndice do conectivo ca. 0,3 mm compr., ovado, amarelo, ápice agudo, filetes amarelos; estilete 7-9 $\mathrm{mm}$ compr., amarelo, ramos do estilete ca. 1,5 $\mathrm{mm}$ compr., ápice agudo, pubescente. Cipselas ca. $4 \mathrm{~mm}$ compr., estreitooblongas, castanhas ou cinza, pubescentes, carpopódio inconspícuo; pápus ca. $1 \mathrm{~mm}$ compr., às vezes com 2 aristas curtas, até ca. 0,25 $\mathrm{mm}$ compr.

Endêmica do Brasil, ocorrendo em todas as Regiões (Nakajima et al. 2015). C7: campo rupestre. Encontrada com flores e frutos em abril.

Material selecionado - Pindobaçu, 1056'36"S, 40²4'28"W, 1000 m s.n.m., abr. 2001, N.G. Jesus et al. 1362 (HUEFS).

Material adicional examinado - BRASIL. MINAS GERAIS: Ouro Branco, jul. 2013, M. Alves et al. 229 (ALCB, HUEFS). PARANÁ: Jaguariaíva, out. 2006, E. Barbosa et al. 1727 (ALCB).

Devido ao indumento viloso nas brácteas involucrais e folhas, Aspilia foliacea pode ser confundida com $A$. riedelii, da qual se distingue por ser uma erva ereta (vs. erva ou arbusto prostrado) e possuir folhas atrofiadas próximas à base (vs. folhas da base de mesmo tamanho que as do ramo).

\subsection{Aspilia foliosa (Gardner) Benth. \& Hook.f., Gen.} P1. 2(1): 372. 1873. Anomostephium foliosum Gardner, London J. Bot. 7: 290. 1848.

$=$ Aspilia parvifolia Mattf., Notizbl. Bot. Gart. BerlinDahlem 9: 386. 1925.

Figuras 11 e 26E.

Arbusto 0,5-2,5 m alt., ereto; ramos cilíndricos, estriados, estrigosos. Folhas opostas, curto-pecioladas (pecícolo até $0,2 \mathrm{~cm}$ compr.); lâmina 0,7-12,5 × 0,1$0,9 \mathrm{~cm}$, coriácea, discolor, linear ou estreito-elíptica, ápice acuminado, geralmente mucronado, margem inteira, revoluta, base cuneada, face adaxial estrigosa, a abaxial serícea. Capítulos solitários ou em corimbos, terminais, $0,8-1,1 \times 0,6-0,8 \mathrm{~cm}$; pedúnculo $0,1-1,1 \mathrm{~cm}$ compr.; invólucro cilíndrico, brácteas involucrais gradativamente maiores, 12-14, em 4 séries, 5-7 × 2-3 $\mathrm{mm}$ compr., lanceoladas ou ovadas, às vezes oblongas, ápice agudo ou acuminado, geralmente mucronado, margem inteira, verde-claras, às vezes vináceas com ápice verde-escuro, estrigoso; páleas $8-10 \times$ ca. $2 \mathrm{~mm}$, lanceoladas, conduplicadas, persistentes, geralmente com carena erosa, ápice agudo, margem inteira, ciliada, às vezes sinuosa. Flores 16-24. Flores do raio 5 ou 6 , 12-13 mm compr.; corola 9-10 mm compr. (tubo 2-3 mm compr.), amarela. Flores do disco 8-9 mm compr.; corola 5-6 $\mathrm{mm}$ compr. (tubo 1-1,5 $\mathrm{mm}$ compr.), amarela; anteras ca. $3 \mathrm{~mm}$ compr., enegrecidas, apêndice do conectivo ca. 0,3 mm compr., ovado,

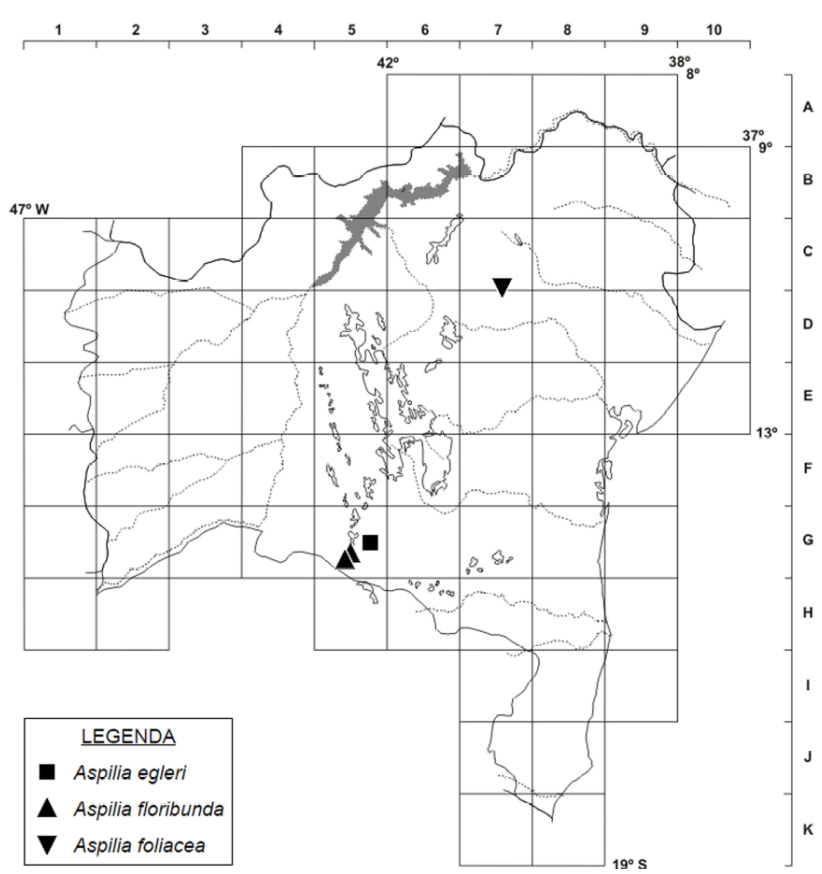

Figura 10. Mapa de distribuição geográfica de Aspilia egleri, A. floribunda e A. foliacea no estado da Bahia.

enegrecido, ápice obtuso, filetes amarelos; estilete 8,5$9 \mathrm{~mm}$ compr., amarelo, ramos do estilete $1-1,5 \mathrm{~mm}$ compr., ápice agudo, pubescente. Cipselas 4-5 mm compr., obovoides, castanhas ou enegrecidas, pubescentes, carpopódio assimétrico; pápus ca. $0,5 \mathrm{~mm}$ compr., ápice eroso.

Endêmica do Brasil, nos estados de Minas Gerais e Bahia (Nakajima et al. 2015). E6, F5, F6: campo rupestre. Encontrada com flores e frutos de setembro a abril.

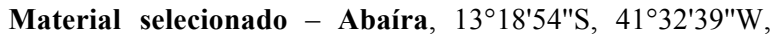
jan. 2006, T.S. Nunes et al. 1489 (HUEFS); Ibicoara, jan. 2011, H.A. Ogasawara et al. 53 (ALCB); Lençóis, abr. 1979, L.R. Noblick 1249 (ALCB); Mucugê, 1255'54"S, 41 ${ }^{\circ} 21^{\prime 2} 23^{\prime \prime} \mathrm{W}, 849 \mathrm{~m}$ s.n.m., jan. 2012, M. Alves \& H.A. Ogasawara 69 (ALCB); Palmeiras, $12^{\circ} 31^{\prime} \mathrm{S}, 41^{\circ} 33^{\prime} \mathrm{W}$, dez. 2007, M.L. Guedes et al. 14291 (ALCB); Piatã, $13^{\circ} 15^{\prime} \mathrm{S}, 41^{\circ} 45^{\prime} \mathrm{W}, 1100 \mathrm{~m}$ s.n.m., out. 1992, W. Ganev 1238 (HUEFS); Rio de Contas, 1350'S, $42^{\circ} 21^{\prime} \mathrm{W}, 1325$ m s.n.m., set. 1993, W. Ganev 2192 (HUEFS).

Santos (2001) considerou Aspilia foliosa próxima a A. jolyana G.M.Barroso, distinguindo-as pelo tamanho das folhas (15-37 cm vs. 8-16 cm compr., respectivamente). Aspilia foliosa, entretanto, apresentou grande variação no tamanho foliar $(0,7-12,5 \mathrm{~cm}$ compr.) na mesma população. Por outro lado, essas espécies podem ser separadas mais precisamente por $A$. jolyana possuir brácteas involucrais em 3 séries (vs. 4), as mais externas com ápice caudado e reflexo e as mais internas com ápice arredondado (vs. todas as brácteas com ápice agudo ou acuminado, reflexas ou não), páleas com apêndice apical circular e ápice obtuso, apendiculado (vs. páleas sem apêndice apical e com ápice agudo). Acredita-se que $A$. jolyana seja endêmica do estado de Minas Gerais e $A$. foliosa ocorra em Minas Gerais e na Bahia. 
4.8. Aspilia leucoglossa Malme, Kongl. Svenska Vetensk.-Akad. Handl. 32(5): 62. 1899.

Figura 11.

Subarbusto $0,4-0,6 \mathrm{~m}$ alt.; ramos cilíndricos, vilosos. Folhas opostas, sésseis; lâmina 3,9-10,3 $\times$ 1,5-4,2 cm, coriácea, discolor, lanceolada, ovada ou amplamente ovada, ápice acuminado, margem conspicuamente serreada, base cuneada ou cordiforme, estrigosa ou setosa em ambas as faces. Capítulos 1-3, terminais, $1,2-2,2 \times 1-2,3 \mathrm{~cm}$; pedúnculo $0,6-2,5 \mathrm{~cm}$ compr.; invólucro campanulado, brácteas involucrais subiguais, $14-25$, em 2 ou 3 séries, $10-18 \times 3-8 \mathrm{~mm}$, lanceoladas ou ovadas, ápice agudo, margem inteira, verdes, às vezes as mais internas similares às páleas em textura, com ápice arredondado, ciliado; páleas 12-13 $\times 1,5-3 \mathrm{~mm}$, lanceoladas, conduplicadas, persistentes, com carena ciliada, apêndice apical lanceolado ou estreito-elíptico, ciliado, às vezes vináceo, ápice agudo, margem inteira. Flores 37-108. Flores do raio ca. 8, 18-26 mm compr.; corola 15-22 mm compr. (tubo 5-6 $\mathrm{mm}$ compr.), alva. Flores do disco $11-15 \mathrm{~mm}$ compr.; corola 7-9 mm compr. (tubo 1,5-3 mm compr.), alva; anteras ca. $4 \mathrm{~mm}$ compr., enegrecidas, apêndice do conectivo ca. $0,5 \mathrm{~mm}$ compr., ovado, alvo, glandular, ápice obtuso, filetes alvos; estilete $12-13 \mathrm{~mm}$ compr., alvo, ramos do estilete ca. 1,5 $\mathrm{mm}$ compr., ápice agudo, pubescente. Cipselas 5-6 $\mathrm{mm}$ compr., estreitooblongas, castanhas, pubescentes, carpopódio inconspícuo; pápus até ca. $1 \mathrm{~mm}$ compr., ápice eroso, com 2 ou 3 aristas de até $4 \mathrm{~mm}$ compr., pubescentes.

Endêmica do Brasil, nas Regiões Norte, Nordeste e Centro-Oeste (Nakajima et al. 2015). D1, D2, G2: cerrado. Encontrada com flores e frutos de dezembro a fevereiro.

Material selecionado - Barreiras, $11^{\circ} 53^{\prime} 13^{\prime \prime} \mathrm{S}, 45^{\circ} 35^{\prime} 22^{\prime \prime} \mathrm{W}$, 720 m s.n.m., jan. 2004, M. Machado \& M.V.M. Oliveira 79 (HUEFS); Cocos, $14^{\circ} 46^{\prime} 35^{\prime \prime} \mathrm{S}, 4^{\circ} 56^{\prime} 32^{\prime \prime} \mathrm{W}, 845 \mathrm{~m}$ s.n.m., dez. 2001, R.C. Mendonça et al. 4569 (RB); Formosa do Rio Preto, $11^{\circ} 33^{\prime} 28^{\prime \prime S}, 46^{\circ} 06^{\prime} 51^{\prime \prime W}, 450$ m s.n.m., fev. 2000, T. Ribeiro et al. 42 (HRB, HUEFS).

Aspilia leucoglossa se destaca das demais espécies do gênero por ser a única no estado que possui corola alva, característica rara em Aspilia e que é encontrada somente em três espécies brasileiras (Santos 2001).

4.9. Aspilia martii Baker in Martius \& Eichler, Fl. Bras. 6(3): 195. 1884.

$=$ Oyedaea bahiensis Baker in Martius \& Eichler, Fl. Bras. 6(3): 206. 1884.

Figuras 11 e 26F.

Arbusto prostrado ca. $0,4 \mathrm{~m}$ alt.; ramos cilíndricos, estriados, vilosos. Folhas opostas, sésseis; lâmina 4-7,3 $\times 0,2-1 \mathrm{~cm}$, cartácea, discolor, linear ou lanceolada, ápice agudo ou acuminado, margem inteira, às vezes revoluta, base cuneada, faces adaxial e abaxial estrigosa ou setosa nas nervações. Capítulos 1 ou 2, terminais, 0,7-0,9 × 0,9-1,2 cm; pedúnculo 5,2-11,8 cm compr.; invólucro campanulado, brácteas involucrais subiguais, 9-11, em 2 séries, 6-10 × 1,5-2 mm, lanceoladas, ápice caudado, margem inteira, verde, setosa; páleas 4,5-6 × 2 $\mathrm{mm}$, lanceoladas ou ovadas, conduplicadas, persistentes, carenadas, ápice agudo ou obtuso, às vezes com apêndice apical triangular, margem inteira. Flores 45 48. Flores do raio 6 ou 7, 8-15 mm compr.; corola 6-13 $\mathrm{mm}$ compr. (tubo 1,5-2,2 mm compr.), amarela. Flores do disco 5-8 mm compr.; corola 3,5-5 $\mathrm{mm}$ compr. (tubo ca. $1 \mathrm{~mm}$ compr.), amarela; anteras ca. $2 \mathrm{~mm}$ compr., enegrecidas, apêndice do conectivo ca. $0,3 \mathrm{~mm}$ compr., ovado, amarelo, ápice obtuso, filetes amarelos; estilete ca. $4 \mathrm{~mm}$ compr., amarelo, ramos do estilete ca. $1,5 \mathrm{~mm}$ compr., ápice agudo, pubescente. Cipselas imaturas ca. 3-4 mm compr., obovoides, castanhas ou enegrecidas com manchas enegrecidas, pubescentes, carpopódio inconspícuo; pápus ca. 0,5 mm compr., ápice eroso, sem ou com até 3 aristas de até $1 \mathrm{~mm}$ compr.

Endêmica do Brasil, com registros para as Regiões Nordeste e Sudeste (Nakajima et al. 2015). C9, D9, E9, G5, G6: áreas antropizadas e cerrado. Encontrada com flores e frutos de agosto a março.

Material examinado - Alagoinhas, set. 1998, N.G. Jesus \& L.C.L. Lima PC 0143 (HUEFS); Aporá, ago. 1996, L.P. Queiroz \& N.S. Nascimento 4660 (HUEFS); Aracatu, $14^{\circ} 25^{\prime} \mathrm{S}, 41^{\circ} 27^{\prime} \mathrm{W}$, jan. 2002, A.M. Giulietti \& R.M. Harley 2522 (ALCB); Brumado, $14^{\circ} 10^{\prime} 58^{\prime \prime} \mathrm{S}, 41^{\circ} 43^{\prime} 28^{\prime \prime} \mathrm{W}, 1130 \mathrm{~m}$ s.n.m., mar. 2002, H.P. Bautista et al. 3212 (HUEFS); Cícero Dantas, jan. 1989, J.A. Carvalho s.n. (HUEFS 11470); Licínio de Almeida, fev. 2012, M. Alves et al. 82 (ALCB, HUEFS).

Aspilia martii diferencia-se das demais espécies do gênero no estado pelo ápice das brácteas involucrais caudado e pelas folhas geralmente lineares. Em áreas onde A. martii ocorre em simpatria com A. riedelii (e.g., Alagoinhas) são encontrados espécimes com características intermediárias às duas espécies, o que sugere hibridação entre elas (veja também comentários em A. bonplandiana).

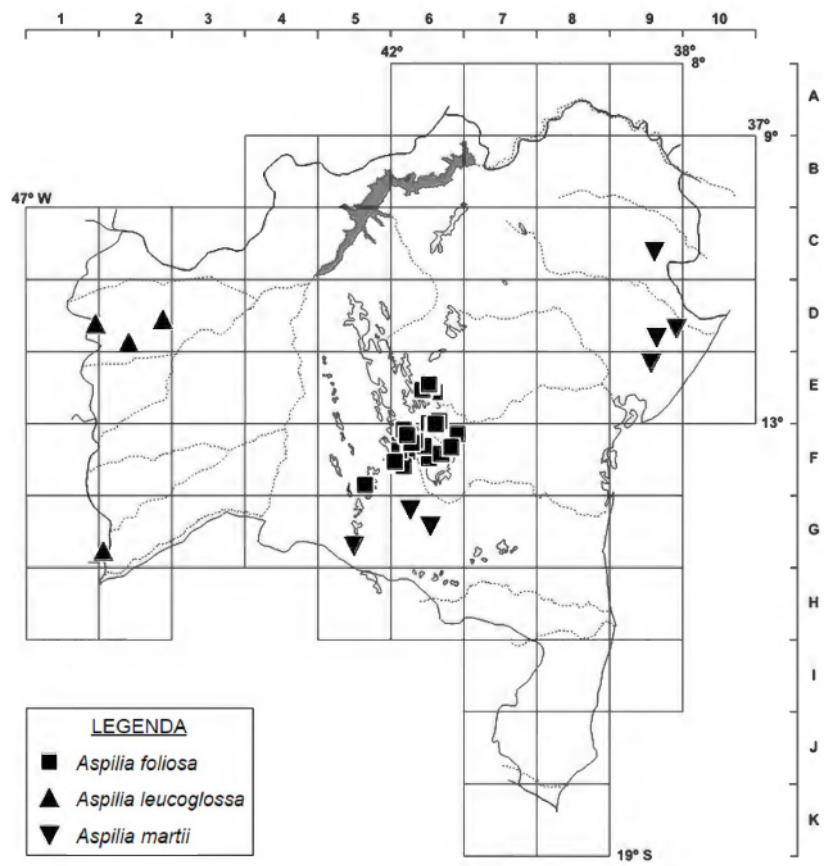

Figura 11. Mapa de distribuição geográfica de Aspilia foliosa, A. leucoglossa e A. martii no estado da Bahia. 
4.10. Aspilia montevidensis (Spreng.) Kuntze, Revis. Gen. Pl. 3(3): 129. 1898. Verbesina montevidensis Spreng., Syst. Veg. 3: 578. 1826.

Figura 12; Baker (1884: prancha 63).

Erva prostrada; ramos cilíndricos, estrigosos ou setosos. Folhas opostas, sésseis; lâmina 2-4 × 0,7-1 cm, cartácea, discolor, estreito-elíptica ou elíptica, ápice agudo, margem serreada, base cuneada, estrigosa ou setosa em ambas as faces. Capítulos solitários, terminais, $0,8-1,1 \times 0,9-1,5 \mathrm{~cm}$; pedúnculo $1,3-5,6$ $\mathrm{cm}$; invólucro campanulado, brácteas involucrais subiguais, 12-16, em 2 séries, as externas 7-9,5 × 1,5$2 \mathrm{~mm}$, as internas 5,5-6,5 × 0,9-1,8 mm, lanceoladas, ápice agudo, margem inteira, verdes, estrigosas; páleas 5,5-6,5 × ca. $1 \mathrm{~mm}$, lanceoladas, conduplicadas, persistentes, geralmente carenadas, apêndice apical lanceolado, pubescente na face abaxial, ápice agudo, margem inteira. Flores 58-61. Flores do raio 9-12, 8,5-11 mm compr.; corola 6-9 mm compr. (tubo 1-2 $\mathrm{mm}$ compr.), amarela. Flores do disco 5-6,5 $\mathrm{mm}$ compr.; corola 3-4 $\mathrm{mm}$ compr. (tubo ca. $1 \mathrm{~mm}$ compr.), amarela; anteras ca. $3 \mathrm{~mm}$ compr., enegrecidas, apêndice do conectivo ca. 0,8 mm compr., ovado, amarelo, ápice obtuso, filetes amarelos; estilete ca. $6 \mathrm{~mm}$ compr., amarelo, ramos do estilete ca. $2 \mathrm{~mm}$ compr., ápice agudo, pubescente. Cipselas imaturas ca. $3 \mathrm{~mm}$ compr., obovoides, pubescentes, carpopódio inconspícuo; pápus até $1 \mathrm{~mm}$ compr., às vezes com 2 aristas de mesmo tamanho.

Ocorre no Paraguai, Argentina, Uruguai e, no Brasil (Santos 2001), no Nordeste, Centro-Oeste, Sudeste e Sul (Nakajima et al. 2015). G8, G9. Encontrada com flores e frutos em agosto.

Material examinado - BRASIL. RIO GRANDE DO SUL:

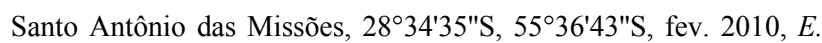
Melo et al. 7753 (HUEFS).

Aspilia montevidensis pode ser confundida com $A$. riedelii devido ao hábito prostrado e capítulos terminais solitários; contudo, distingue-se dela por geralmente possuir ramos estéreis (vs. ausentes em $A$. riedelii), lâmina foliar séssil (vs. pecíolo $0,2-0,4 \mathrm{~cm}$ compr.), estrigosa ou setosa em ambas as faces (vs. vilosa) e sem nervações secundárias evidentes ou evidentes apenas na face abaxial (vs. nervações secundárias evidentes em ambas as faces). Santos (2001) cita $A$. montevidensis para a Bahia com base na coleção Silveira s.n. (R s.n.: Ilhéus, ago. 1894), que não foi encontrada; assim, a descrição foi preparada com base em um espécime de outro estado (Rio Grande do Sul) e na descrição de Santos (2001).

4.11. Aspilia prostrata J.U.Santos, Revista Brasil. Bot. 19(1): 88. 1996.

Figuras 12 e $26 \mathrm{G}$.

Subarbusto, ereto ou prostrado, até $0,4 \mathrm{~m}$ alt.; ramos cilíndricos, estriados, estrigosos. Folhas opostas, curto-pecioladas (pecíolo 0,1-0,3 cm compr.), lâmina $0,9-4 \times 0,3-1,4 \mathrm{~cm}$, cartácea ou subcoriácea, discolor, estreito-elíptica ou elíptica, ápice agudo ou acuminado, mucronado, margem inteira ou serreada no 1/3 apical, base cuneada, estrigosa em ambas as faces. Capítulos solitários, terminais, $0,7-1 \times 0,4-1,7 \mathrm{~cm}$; pedúnculo 1,3-4,7 cm compr.; invólucro campanulado, brácteas involucrais subiguais, 11 ou 12, em 2 séries, 6-10 × 2-3 mm, lanceoladas ou ovadas, ápice agudo ou acuminado, margem inteira, verdes ou verdes com ápice vináceo, às vezes similares às páleas em textura; páleas 6-10 × 1-2 $\mathrm{mm}$, estreito-elípticas, conduplicadas, persistentes, carenadas, apêndice apical elíptico, inflexo, ápice agudo, margem erosa. Flores 21-32. Flores do raio 5-7, 10,5-16 mm compr.; corola 9-14 $\mathrm{mm}$ compr. (tubo 2-3 $\mathrm{mm}$ compr.), amarela. Flores do disco 5-9 mm compr.; corola 4-6,5 $\mathrm{mm}$ compr. (tubo 1-2 mm compr.), amarela; anteras ca. 3 mm compr., enegrecidas, apêndice do conectivo ca. 0,5 mm compr., ovado, amarelo, ápice obtuso, filetes amarelos; estilete ca. $7 \mathrm{~mm}$ compr., amarelo, ramos do estilete ca. $1 \mathrm{~mm}$ compr., ápice agudo, pubescente. Cipselas 4,5-5,5 mm compr., obovoides, enegrecidas, castanhas e vináceas, pubescentes, carpopódio assimétrico; pápus ca. $1 \mathrm{~mm}$ compr., ápice eroso.

Conhecida somente pelo exemplar-tipo, coletado na Serra do Cipó (Minas Gerais) em 1981, sendo este o primeiro registro da espécie para o estado da Bahia. G5: cerrado. Encontrada com flores e frutos em fevereiro.

Material examinado - Licínio de Almeida, fev. 2014, M. Alves et al. 321 (ALCB, HUEFS).

Aspilia prostrata se diferencia de $A$. subalpestris pela lâmina foliar cartácea a subcoriácea (vs. coriácea), geralmente serreada no 1/3 apical e plana (vs. margem inteira e revoluta) e pela quantidade menor de flores, 21-32 (vs. 48-67).

\subsection{Aspilia riedelii Baker in Martius \& Eichler, Fl. Bras. 6(3): 196. 1884.}

Figuras 12 e $26 \mathrm{H}$.

Erva, subarbusto ou arbusto, geralmente prostrado ou com parte ereta, ca. 0,3 cm alt.; ramos cilíndricos, estriados, vilosos. Folhas opostas, curto-pecioladas (pecíolo 0,2-0,4 cm compr.), lâmina 2,4-6,6 × 0,7-1,5 $\mathrm{cm}$, cartácea, levemente discolor, estreito-elíptica ou elíptica, ápice agudo ou acuminado, serreada nos $2 / 3$ apicais, base atenuada ou cuneada, faces adaxial e abaxial vilosas. Capítulos solitários, terminais ou axilares, 1,2-1,4 × 1-1,2 cm; pedúnculo 1,2-3,9 cm compr.; invólucro campanulado, brácteas involucrais subiguais, 13-16, em 2 ou 3 séries, lanceoladas ou ovadas, ápice agudo ou acuminado, raramente arredondado nas mais internas, margem inteira, verdes, às vezes as mais internas similares às páleas em textura, vilosas; páleas 8-10 × 2-3 mm compr., lanceoladas, conduplicadas, persistentes, carenadas, apêndice apical elíptico, ápice agudo, margem inteira, às vezes ciliada, com ou sem glândulas na parte apical. Flores 32-46. Flores do raio 5-8, 16-18 mm compr.; corola 13-15 mm compr. (tubo 3-4 mm compr.), amarela. Flores do disco 10-12 mm compr.; 


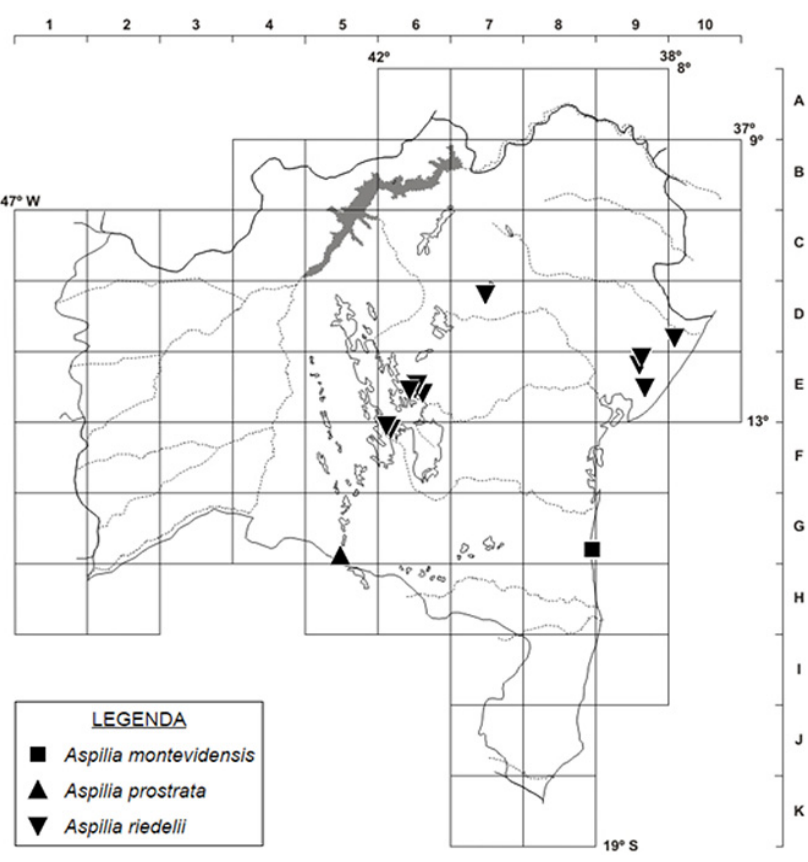

Figura 12. Mapa de distribuição geográfica de Aspilia montevidensis, $A$. prostrata e $A$. riedelii no estado da Bahia.

corola 5-8 $\mathrm{mm}$ compr. (tubo ca. $2 \mathrm{~mm}$ compr.), amarela; anteras ca. $3 \mathrm{~mm}$ compr., enegrecidas, apêndice do conectivo ca. $0,5 \mathrm{~mm}$ compr., ovado, amarelo, ápice obtuso, filetes amarelos; estilete ca. 7 $\mathrm{mm}$ compr., amarelo, ramos do estilete ca. $1 \mathrm{~mm}$ compr., ápice agudo, pubescente. Cipselas 4,5-5,5 mm compr., obovoides, enegrecidas, castanhas e vináceas, pubescentes, carpopódio assimétrico; pápus ca. $1 \mathrm{~mm}$ compr., ápice eroso.

Endêmica do Brasil, com registros para as Regiões Nordeste, Sudeste e Sul (Nakajima et al. 2015). D7, D10, E6, E9, F6: cerrado e campo rupestre. Encontrada com flores e frutos de outubro a abril.

Material selecionado - Alagoinhas, $12^{\circ} 03^{\prime} 54^{\prime \prime} \mathrm{S}, 38^{\circ} 21^{\prime} 34^{\prime \prime} \mathrm{W}$, 174 m s.n.m., abr. 2010, E. Melo et al. 7972 (HUEFS); Camaçari, 12²9'35"S, 38¹8'47"W, dez. 1982, L.R. Noblick et al. 2241 (HUEFS); Jacobina, jan. 2012, L.M. Moura 187 (ALCB); Lençóis, $12^{\circ} 34^{\prime} \mathrm{S}, 41^{\circ} 23^{\prime} \mathrm{W}$, out. 1982, C.M.B. Lobo 53 (HUEFS); Palmeiras, $12^{\circ} 28^{\prime} 20^{\prime \prime S}, 41^{\circ} 28^{\prime} 15^{\prime \prime W}, 1100$ m s.n.m., ago. 1994, M.L. Guedes et

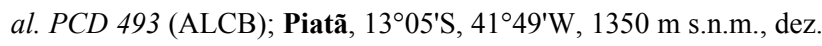
1992, W. Ganev 1727 (HUEFS).

Aspilia riedelii pode ser confundida com $A$. foliacea, da qual se distingue por ser uma erva a arbusto prostrado (vs. erva ereta) com folhas da base do mesmo tamanho que as do ramo (vs. folhas atrofiadas próximas à base.). Veja também comentários em A. martii e A. montevidensis.

\subsection{Aspilia squarrosa Baker in Martius \& Eichler,} Fl. Bras. 6(3): 203. 1884.

Figuras 13 e 26I.

Arbusto $0,5-1,5 \mathrm{~m}$ alt.; ramos cilíndricos, estriados, estrigosos ou tomentosos. Folhas opostas, sésseis ou curto-pecioladas (pecíolo até $0,5 \mathrm{~cm}$ compr.), lâmina 3$8 \times 6-14,5 \mathrm{~cm}$, cartácea ou subcoriácea, discolor, lanceolada, ápice agudo, mucronado, margem inteira, às vezes revoluta, base atenuada, cuneada ou arredondada, face adaxial estrigosa, a abaxial tomentosa. Capítulos $1-3$, terminais, $0,8-1,4 \times 0,7-1,2 \mathrm{~cm}$ compr.; pedúnculo 0,5-2 cm compr.; invólucro cilíndrico ou campanulado, brácteas involucrais gradativamente maiores, 19-21, em 3 ou 4 séries, lanceoladas, as mais externas $6-8 \times$ ca. 3 $\mathrm{mm}$, as mais internas 8-9 $\times 2,5-3 \mathrm{~mm}$, ápice agudo ou acuminado, às vezes mucronado, margem inteira, estrigosas ou setosas, às vezes somente no ápice, verdeclaras com ápice verde-escuro; páleas 7-9 × 2-3 mm, lanceoladas, conduplicadas, persistentes, geralmente carenadas, apêndice apical ovado, ápice agudo, às vezes amarelo ou vináceo, margem inteira, ciliada, pubescente na face abaxial, principalmente próximo ao ápice. Flores 21-30. Flores do raio 6-8, 15-16 mm compr.; corola 13-14 mm compr. (tubo 3-4 mm compr.), amarela. Flores do disco 9-11 mm compr.; corola 6-7 $\mathrm{mm}$ compr. (tubo 1,5-2 $\mathrm{mm}$ compr.), amarela; anteras ca. $3 \mathrm{~mm}$ compr., enegrecidas, apêndice do conectivo ca. $0,5 \mathrm{~mm}$ compr., ovado, enegrecido, ápice obtuso, filetes amarelos; estilete ca. $10 \mathrm{~mm}$ compr., amarelo, ramos do estilete ca. $1 \mathrm{~mm}$ compr., ápice agudo, pubescente. Cipselas 5-6 $\mathrm{mm}$ compr., estreito-oblongas ou oblongas, enegrecidas, castanhas e vináceas, pubescentes, carpopódio assimétrico; pápus até $1 \mathrm{~mm}$ compr., ápice eroso.

Endêmica do Brasil, com registros para Minas Gerais e Bahia (Nakajima et al. 2015). F5, F6, G5: campo rupestre. Encontrada com flores e frutos durante o ano todo.

Material selecionado - Abaíra, $13^{\circ} 22^{\prime} \mathrm{S}, 41^{\circ} 49^{\prime} \mathrm{W}, 1180 \mathrm{~m}$ s.n.m., jan. 1994, W. Ganev 2897 (HUEFS); Piatã, 13²16'S, 41 ${ }^{\circ} 43^{\prime}$ W, 1100 m s.n.m., dez. 1991, W. Ganev 1732 (HUEFS); Rio de Contas, $13^{\circ} 23^{\prime} \mathrm{S}, 41^{\circ} 46^{\prime} \mathrm{W}, 930 \mathrm{~m}$ s.n.m., jan. 1994, W. Ganev 2861 (HUEFS).

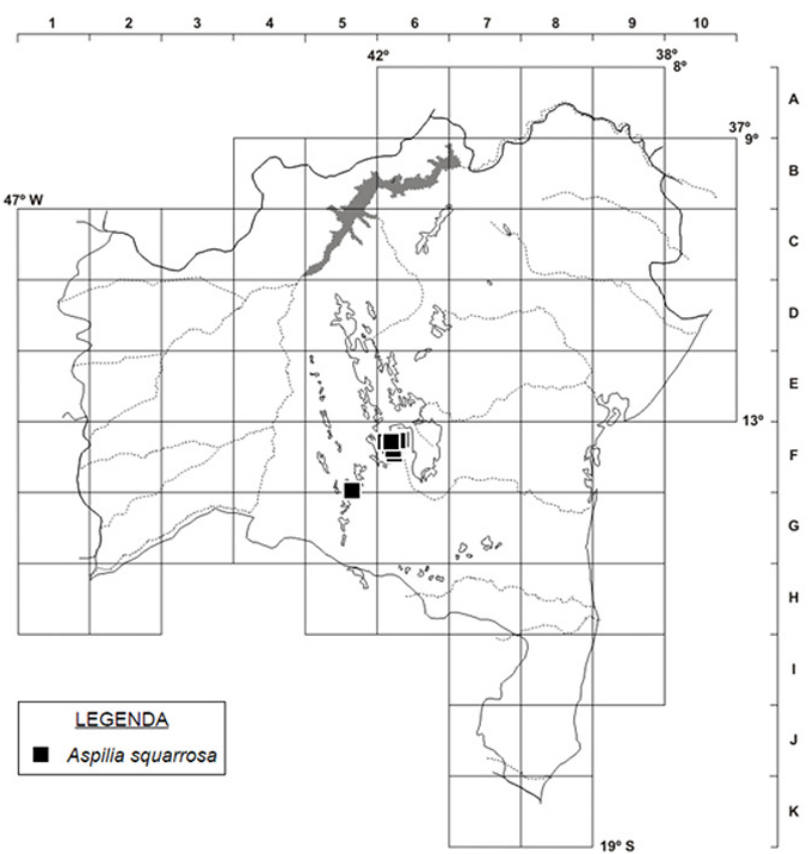

Figura 13. Mapa de distribuição geográfica de Aspilia squarrosa no estado da Bahia. 
Aspilia squarrosa é geralmente confundida com $A$. almasensis, diferindo pelas lâminas foliares maiores (3-8 $\times 6-14,5 \mathrm{~cm}$ vs. $1,2-3,6 \times 0,3-0,8 \mathrm{~cm})$, sempre lanceoladas (vs. lanceoladas ou ovadas) e com face abaxial cinérea quando seca (vs. castanha quando seca).

\subsection{Aspilia subalpestris Baker in Martius \& Eichler,} Fl. Bras. 6(3): 202. 1884.

Figuras 14 e 27A.

Subarbusto ou arbusto, ereto ou decumbente, 0,3$1 \mathrm{~m}$ alt.; ramos cilíndricos, estriados, estrigosos. Folhas opostas, curto-pecioladas (pecíolo até $0,2 \mathrm{~cm}$ compr.); lâmina $1,7-2,7 \times 0,4-1,2 \mathrm{~cm}$, coriácea, discolor, estreito-elíptica ou elíptica, ápice agudo, raramente obtuso, mucronado, margem inteira, revoluta, base cuneada, faces adaxial e abaxial estrigosas. Capítulos 1-3, terminais, 0,8-1,5 × 1-2,3 $\mathrm{cm}$; pedúnculo $0,9-6,4 \mathrm{~cm}$ compr.; invólucro campanulado, brácteas involucrais subiguais, 13-21, em 2 séries, 7-13,5 × 2,5-8 mm, lanceoladas ou ovadas, ápice agudo ou obtuso, margem inteira, verdes, estrigosas, às vezes as mais internas similares às páleas em textura; páleas 7-11 × $2 \mathrm{~mm}$, lanceoladas ou estreito-oblongas, conduplicadas, persistentes, geralmente carenadas, apêndice apical ovado, ápice agudo, margem erosa. Flores 48-67. Flores do raio 10-12, 12-25 mm compr.; corola 10-23 mm compr. (tubo 2-3 mm compr.), amarela. Flores do disco 6,5$12 \mathrm{~mm}$ compr.; corola 5-7 mm compr. (tubo 1-2 mm compr.), amarela; anteras ca. 3,5 $\mathrm{mm}$ compr., enegrecidas, apêndice do conectivo ca. $0,5 \mathrm{~mm}$ compr., ovado, amarelo, ápice obtuso, filetes amarelos; estilete ca. $9 \mathrm{~mm}$ compr., amarelo, ramos do estilete ca. $1 \mathrm{~mm}$ compr., ápice agudo, pubescente. Cipselas $2-5 \mathrm{~mm}$ compr., oblanceoloides ou obovoides, enegrecidas, pubescentes, carpopódio inconspícuo; pápus ca. $1 \mathrm{~mm}$ compr., ápice eroso, às vezes com 2 aristas de mesmo tamanho.

Endêmica do Brasil, com registros de coleta para Minas Gerais e Bahia (Nakajima et al. 2015). E6, F6: campo rupestre. Encontrada com flores e frutos de setembro a fevereiro.

Material selecionado - Abaíra, $13^{\circ} 14^{\prime} \mathrm{S}, 41^{\circ} 50^{\prime} \mathrm{W}, 1300 \mathrm{~m}$ s.n.m., nov. 1992, W. Ganev 1600 (HUEFS); Barra da Estiva, $13^{\circ} 35^{\prime} \mathrm{S}, 41^{\circ} 18^{\prime} \mathrm{W}$, set. 2010, M.L. Guedes et al. 17663 (ALCB); Ibicoara, $13^{\circ} 16^{\prime} 47^{\prime \prime S}, 41^{\circ} 22^{\prime} 30^{\prime \prime} \mathrm{W}, 1072 \mathrm{~m}$ s.n.m., fev. 2012, T.S. Nunes 872 (HUEFS); Mucugê, 12¹5'25"S, 3855'54"W, $995 \mathrm{~m}$ s.n.m., jan. 2012, M. Alves \& Ogasawara, H.A. 43 (ALCB, HUEFS); Palmeiras, $12^{\circ} 27^{\prime} 10^{\prime \prime S}, 4^{\circ} 28^{\prime} 27^{\prime \prime} \mathrm{W}, 900$ m s.n.m., jun. 1995, M.L. Guedes et al. PCD 1973 (ALCB); Piatã, 1309'S,

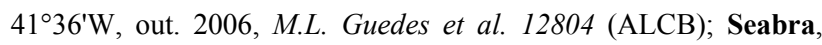
$12^{\circ} 12^{\prime} 08^{\prime \prime S}, 41^{\circ} 49^{\prime} 36^{\prime \prime} \mathrm{W}, 1200-1300 \mathrm{~m}$ s.n.m., jun. 1993, L.P. Queiroz \& N.S. Nascimento 3347 (HUEFS).

Aspilia subalpestris foi descrita por Baker (1884) com base no exemplar-tipo, coletado no município de Rio de Contas. Posteriormente, Santos (1985), a partir da análise da fotografia do tipo e de materiais de Minas Gerais e Goiás, transferiu a espécie para o gênero
Wedelia. Segundo ele, a espécie possuía flores do raio femininas. Contudo, o material-tipo de Aspilia subalpestris é diferente daqueles analisados por Santos (1985), com folhas distintas e flores do raio neutras, característica diagóstica de Aspilia. Concomitantemente, Robinson (1984) descreveu Aspilia hispidantha H.Rob., cujo material-tipo é proveniente do município de Mucugê, também na Chapada Diamantina. A partir dos trabalhos de campo em Mucugê e Rio de Contas, bem como da análise de espécimes de herbários, $A$. subalpestris e $A$. hispidantha não apresentam diferenças morfológicas e devem ser sinonimizadas.

\subsection{Aspilia subscandens J.U.Santos, Bol. Mus.} Paraense "Emilio Goeldi," N.S., Bot. 9(2): 213. 1994.

Figura 14.

Arbusto subescandente; ramos cilíndricos, estrigosos. Folhas opostas, curto-pecioladas (pecíolo $0,2-0,3 \mathrm{~cm}$ compr.); lâmina $3-5,5 \times 0,9-1,3 \mathrm{~cm}$, coriácea, discolor, lanceolada, ápice mucronado, margem inteira, às vezes revoluta, cuneada ou atenuada, faces adaxial e abaxial glabrescente ou estrigosa nas nervações. Capítulos solitários, terminais, 6,3-10,5 × 4,9-9 cm; pedúnculo 1,1-2,4 cm compr.; invólucro subgloboso, brácteas involucrais gradativamente maiores, 18-24, em 4 ou 5 séries, ovadas, 6-8,5 × 2-3 mm, ápice agudo, acuminado ou mucronado, margem inteira, glabrescente ou estrigosa; páleas 7-9 × 2-3 $\mathrm{mm}$, lanceoladas, conduplicadas, persistentes, ápice agudo. Flores 18-20. Flores do raio ca. $11 \mathrm{~mm}$ compr.; corola ca. $9 \mathrm{~mm}$ compr. (tubo ca. 3 $\mathrm{mm}$ compr.), amarela. Flores do disco $8-10 \mathrm{~mm}$ compr.; corola 4-5 $\mathrm{mm}$ compr. (tubo ca. $1 \mathrm{~mm}$ compr.), amarela; anteras ca. $3 \mathrm{~mm}$ compr., enegrecidas, apêndice do conectivo ca. $0,25 \mathrm{~mm}$ compr., ovado, enegrecido, ápice agudo, filetes amarelos; estilete ca. $7 \mathrm{~mm}$ compr., amarelo, ramos do estilete ca. 1,5 mm compr., ápice agudo, pubescente. Cipselas ca. $5 \mathrm{~mm}$ compr., oblanceoloides, castanhas, carpopódio inconspícuo; pápus ca. $1 \mathrm{~mm}$ compr.

Conhecida apenas pelo exemplar-tipo. G7. Encontrada com flores e frutos em janeiro.

Material examinado - Vitória da Conquista, jan. 1965, $G$. Pabst 8422 \& E. Pereira 9533 (isótipo R).

É a única espécie de Aspilia com hábito arbustivo subescandente encontrada na Bahia (Santos 2001).

\section{Baltimora L.}

Ervas ou arbustos eretos, anuais. Folhas opostas, pecioladas; lâmina lanceolada ou ovada. Capítulos radiados, terminais e axilares, em racemos ou panículas; brácteas involucrais subiguais, em 2 ou 3 séries, ovadas; receptáculos planos ou convexos, paleáceos. Flores do raio femininas; corola do raio verdadeira, ápice emarginado, amarela ou amareloalaranjada. Flores do disco funcionalmente masculinas; 


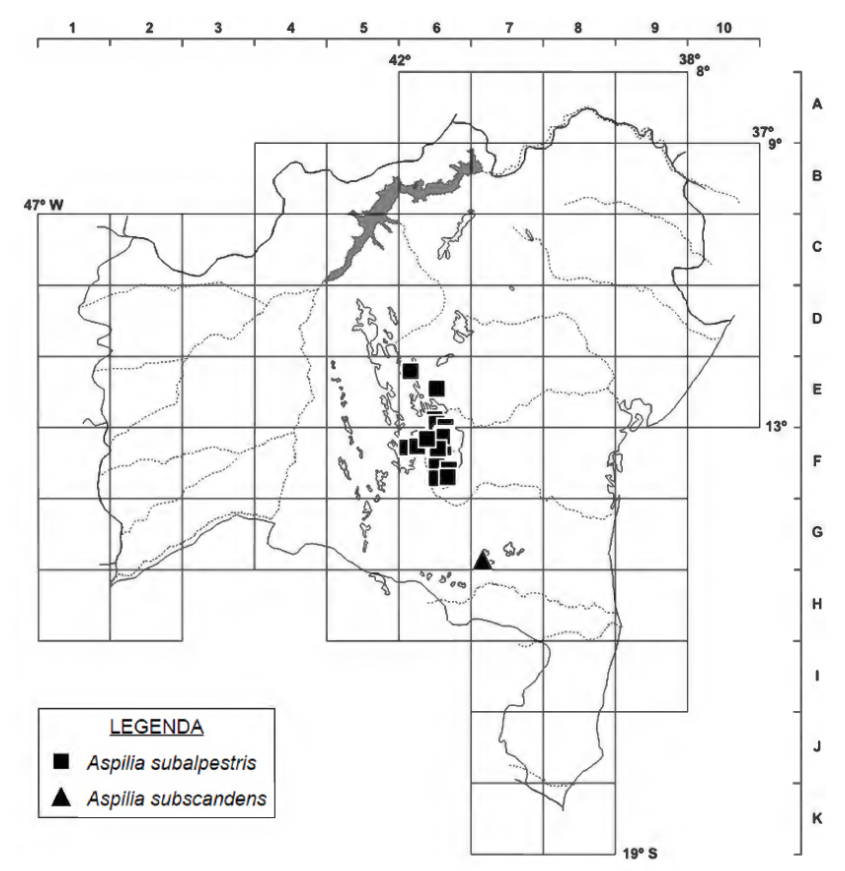

Figura 14. Mapa de distribuição geográfica de Aspilia subalpestris e A. subscandens no estado da Bahia.

corola tubulosa, lacínias reflexas, papilosas, amarela; anteras com apêndice basal sagitado com tricomas glandulares, enegrecidas; estilete filiforme com ramos recurvados. Cipselas tríquetras ou obpiramidais, superficial ou fortemente tuberculadas, enegrecidas; pápus coroniforme, diminuto.

Dentre as características descritas por Panero (2007), as cipselas obpiramidais e o pápus coroniforme diminuto se destacam para o reconhecimento de Baltimora. O gênero possui duas espécies e distribuição neotropical (Panero 2007); ambas ocorrem no Brasil e uma na Bahia (Nakajima et al. 2015).

5.1. Baltimora geminata (Brandegee) Stuessy, Fieldiana, Bot. 36(5): 42. 1973. Melampodium geminata Brandegee, Zoë 5: 223. 1905.

Figuras 15 e $17 \mathrm{~A}-\mathrm{E}$.

Arbusto ca. $1 \mathrm{~m}$ alt.; ramos cilíndricos, estriados, estrigosos. Folhas com pecíolo 0,2-4,4 cm compr.; lâmina $6,5-11 \times 1,7-9 \mathrm{~cm}$, membranácea, discolor, lanceolada, ovada ou amplamente ovada, ápice acuminado ou caudado, margem serreada, base arredondada ou atenuada, faces adaxial e abaxial estrigosas ou setosas nas nervações. Capitulescências paniculiformes, terminais ou axilares; pedúnculo 0,3$2,3 \mathrm{~cm}$ compr. Capítulos $0,4-0,6 \times 0,2-1 \mathrm{~cm}$; invólucro campanulado, brácteas involucrais 5-7, em 2 séries, 2,5-5 × 1-2,5 mm, ápice agudo ou acuminado, margem inteira, ciliada, verdes; receptáculo plano, páleas 3,5-4 × ca. $1 \mathrm{~mm}$, lanceoladas, conduplicadas, persistentes, ápice agudo eroso ou truncado setuloso, margem inteira. Flores do raio ca. 5, 4-5 mm compr.; corola 3-3,5 $\mathrm{mm}$ compr. (tubo ca. $1 \mathrm{~mm}$ compr., glabro); estilete ca. $2 \mathrm{~mm}$ compr., amarelo, ramos do

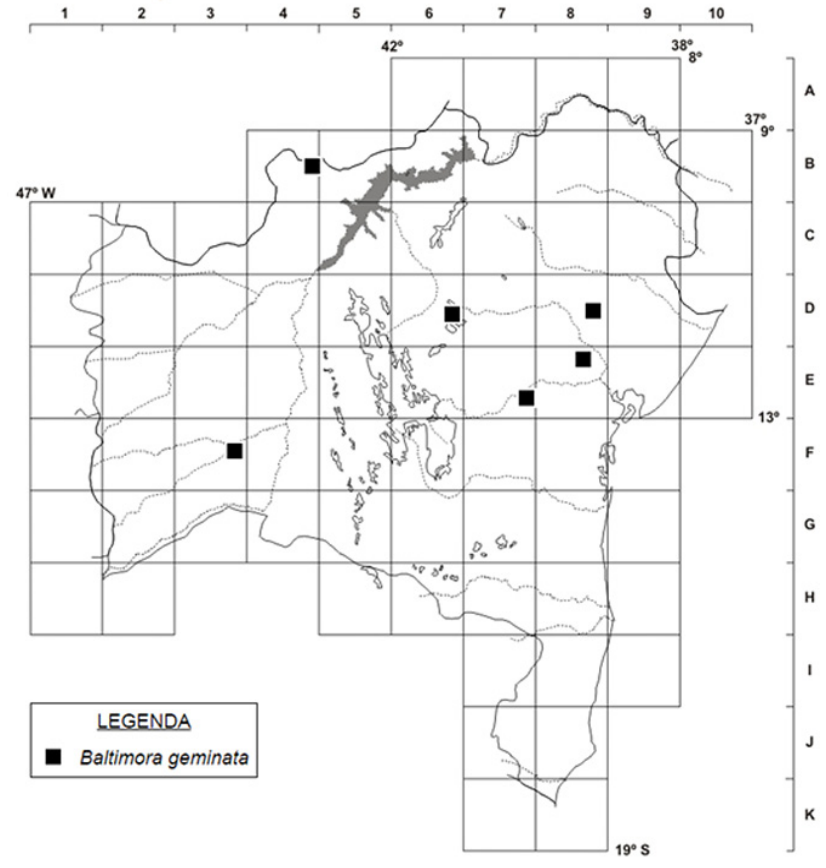

Figura 15. Mapa de distribuição geográfica de Baltimora geminata no estado da Bahia.

estilete ca. $1 \mathrm{~mm}$ compr., ápice agudo. Flores do disco ca. 10, 3-4 mm compr.; corola ca. 2-2,5 mm compr. (tubo ca. 0,5 mm compr., glabro) amarela; anteras ca. $1,1 \mathrm{~mm}$ compr., apêndice do conectivo ca. $0,1 \mathrm{~mm}$ compr., ovado, ápice agudo, enegrecidas, filetes amarelos. Cipselas 2,5-3 $\mathrm{mm}$ compr., tuberculadas, pubescentes no ápice, carpopódio elíptico; pápus coroniforme, escamas ca. 0,1 mm compr.

Ocorre no México, América Central e América do Sul (Stuessy 1973); no Brasil, possui registros para o Tocantins e estados da Região Centro-Oeste, Nordeste e Sudeste (Nakajima et al 2015). B4, D6, D8, E7, E8, F3: áreas antropizadas. Encontrada com flores e frutos de setembro a abril.

Material selecionado - Campo Alegre de Lourdes, 09²9'10"S, 43º5'24"W, 480 m s.n.m., abr. 2004, J.G. CarvalhoSobrinho et al. 215 (HUEFS); Conceição do Coité, 11³0'S, $39^{\circ} 12^{\prime} \mathrm{W}$, set. 2012, D.N. Carvalho 97 (HUEFS); Iaçu, 12 $43^{\prime} \mathrm{S}$, $40^{\circ} 07^{\prime} \mathrm{W}$, mar. 1985, L.R. Noblick 3694 (HUEFS); Morro do Chapéu, abr. 2008, E. Melo et al. 5662 (HUEFS); Santa Maria da Vitória, $13^{\circ} 27^{\prime} 00^{\prime \prime S}, 44^{\circ} 10^{\prime} 16^{\prime \prime} \mathrm{W}$, fev. 2000, L.P. Queiroz et al. 5966 (ALCB, HRB); Serra Preta, $12^{\circ} 10^{\prime} \mathrm{S}, 39^{\circ} 20^{\prime} \mathrm{W}$, jul. 1985, L.R. Noblick \& Lemos 4203 (HUEFS).

Baltimora geminata é geralmente identificada como Blainvillea acmella, da qual se distingue por possuir cipselas geralmente tuberculadas (vs. lisas) e pápus coroniforme de escamas diminutas (vs. pápus de aristas intramarginais com 2 ou 3 aristas).

\section{Blainvillea Cass.}

Ervas ou arbustos. Folhas opostas ou alternas; lâmina lanceolada ou largamente ovada. Capítulos radiados, terminais, em cimeiras paniculiformes 
abertas; brácteas involucrais em 2-4 séries, cartáceas com estrias longitudinais verdes; receptáculo plano ou convexo, paleáceo. Flores do raio femininas; corola do raio verdadeira, alva ou amarela. Flores do disco bissexuadas; corola tubulosa, alva ou amarela; anteras enegrecidas, apêndices do conectivo com ou sem tricomas glandulares; ramos do estilete agudos, pubescentes. Cipselas obpiramidais, obcompressas ou compressas; pápus com 2 ou 3 aristas intramarginais, às vezes com páleas fusionadas na base.

Blainvillea pode ser reconhecido pelo pápus com aristas intramarginais e estrias verdes nas brácteas involucrais. Abrange dez espécies e possui distribuição pantropical (Panero 2007). São registradas duas espécies para o Brasil (Nakajima et al. 2015), uma delas no estado da Bahia.

6.1. Blainvillea acmella (L.) Philipson, Blumea 6(2): 350. 1950. Verbesina acmella L., Sp. Pl. 2: 901. 1753.

$=$ Blainvillea rhomboidea Cass., Dict. Sci. Nat. (ed. 2) 29: 493. 1823.

Figuras $16,17 \mathrm{~F}-\mathrm{K}$ e $27 \mathrm{~B}$.

Arbusto 0,3-1,5 $\mathrm{m}$ alt.; ramos cilíndricos, estriados, às vezes vináceos, tomentosos. Folhas com pecíolo 0,3-2,5 cm compr.; lâmina 3,5-9,5(13,8) × $1,8-4,8(7,2) \mathrm{cm}$, cartácea, discolor, lanceolada ou ovada, às vezes trulada ou rômbica, ápice agudo ou acuminado, margem serreada, base arredondada ou atenuada, face adaxial estrigosa, a abaxial tomentosa, glandulosas. Capitulescências em dicásios axilares ou terminais; pedúnculo $0,3-4,6 \mathrm{~cm}$ compr. Capítulos $0,5-1 \times 0,4-1 \mathrm{~cm}$; invólucro subgloboso, brácteas involucrais subiguais, 5-7, em 2 séries, 4-8 $\times 2-3 \mathrm{~mm}$, lanceoladas ou ovadas, ápice obtuso, agudo ou acuminado, margem inteira, setosas, verde-claras, com estrias verde-escuras; receptáculo plano, páleas 4-7 $\times$ ca. $2 \mathrm{~mm}$ compr., estreito-elípticas ou elípticas, conduplicadas, persistentes, ápice eroso, margem inteira. Flores 14-22. Flores do raio 5 ou $6,5,5-7$ $\mathrm{mm}$ compr.; corola 2,5-4 mm compr. (tubo 1,5-2,5 $\mathrm{mm}$ compr., glabro), alva. Flores do disco 4,5-8 $\mathrm{mm}$ compr.; corola 2-4 mm compr. (tubo 1-2 mm compr., glabro), alva; anteras ca. $1 \mathrm{~mm}$ compr., apêndice do conectivo ca. 0,2 $\mathrm{mm}$ compr., lanceolado, alvo, ápice obtuso ou agudo, apêndice basal sagitado, filetes alvos; estilete ca. $2 \mathrm{~mm}$ compr., alvo, ramos do estilete ca. 0,5 $\mathrm{mm}$ compr. Cipselas $3-5 \mathrm{~mm}$ compr., às vezes compressas, enegrecidas, castanhas ou castanhas com manchas enegrecidas, carpopódio triangular; pápus com 2 ou 3 aristas de 1-3 mm compr., pubescentes.

Ocorre na Ásia, Oceania e América do Sul (Tropicos 2015); no Brasil, possui registros para estados das cinco Regiões (Nakajima et al. 2015). B4, B7, B9, C7, D4, D5, D6, D7, D8, E7, E8, E9, F4, F6, F7, F8, G3, G4, G5, G6, G7, G8, I8: áreas antropizadas. Encontrada com flores e frutos durante todo o ano.
Material selecionado - Abaíra, 900 m s.n.m., jan. 1992, D.J.N. Hind et al. H 51404 (CEPEC, HUEFS, SP); Alagoinhas, $12^{\circ} 11^{\prime} 08^{\prime \prime S}, 38^{\circ} 25^{\prime} 21^{\prime \prime} \mathrm{W}$, ago. 2002, G.S.S. Almeida 17 (ALCB); Anguera, $39^{\circ} 12^{\prime} \mathrm{W}, 12^{\circ} 10^{\prime}$ S, 130 m s.n.m., set. 1996, E. Melo 1705 (HUEFS); Bom Jesus da Lapa, 1315'20"S, 4327'08"W, $460 \mathrm{~m}$ s.n.m., abr. 2002, F. França et al. 3863 (ALCB, HUEFS); Brotas de Macaúbas, $11^{\circ} 56^{\prime} 11^{\prime \prime S}, 42^{\circ} 45^{\prime} 21^{\prime \prime} \mathrm{W}, 1035 \mathrm{~m}$ s.n.m., fev. 2013 M. Alves \& L. Campos 129 (ALCB); Cachoeira, $12^{\circ} 32^{\prime} \mathrm{S}, 39^{\circ} 05^{\prime} \mathrm{W}$, 40-120 m s.n.m., jun-ago. 1980, Grupo Pedra do Cavalo 274 (ALCB); Camaçari, jun. 2003, G. Hatschbach et al. 75450 (CEPEC); Campo Alegre de Lourdes, $09^{\circ} 28^{\prime} 47^{\prime \prime} \mathrm{S}, 43^{\circ} 05^{\prime} 15^{\prime \prime} \mathrm{W}$, 632 m s.n.m., abr. 2004, J.G. Carvalho-Sobrinho et al. 243 (HUEFS); Carinhanha, $14^{\circ} 12^{\prime} 23^{\prime \prime} \mathrm{S}, 43^{\circ} 58^{\prime} 14^{\prime \prime} \mathrm{W}, 460$ m s.n.m., abr. 2002, F. França et al. 3818 (ALCB, HUEFS); Conceição do Coité, $11^{\circ} 30^{\prime} \mathrm{S}, 39^{\circ} 11^{\prime} \mathrm{W}$, jun. 2013, D.N. Carvalho 271 (HUEFS); Cruz das Almas, mar. 1975, G.C.P. Pinto 42544 (ALCB); Eunápolis, $16^{\circ} 22^{\prime} \mathrm{S}, 39^{\circ} 00^{\prime} \mathrm{W}$, nov. 2000, M.L. Guedes et al. 7554 (ALCB); Feira de Santana, $1^{\circ} 15^{\prime} \mathrm{S}, 38^{\circ} 58^{\prime} \mathrm{W}$, jun. 1982, C.M.B. Lobo 9 (ALCB); Glória, ago. 1995, F.P. Bandeira 254 (HUEFS); Guanambi, $14^{\circ} 28^{\prime} 34^{\prime \prime S}, 42^{\circ} 38^{\prime} 23^{\prime \prime W}, 840$ m s.n.m., abr. 2011, $L$. Pataro \& R.B. Oliveira 127 (ALCB); Iaçu, $12^{\circ} 43^{\prime} \mathrm{S}, 40^{\circ} 07^{\prime} \mathrm{W}$, mar. 1985, L.R. Noblick \& Lemos 3607 (CEPEC, HUEFS, UEC); Ilhéus, maio 1965, R.P. Belém 962 (CEPEC); Itaberaba, 13²43'S, $39^{\circ} 08^{\prime} \mathrm{W}$, abr. 2006, M.L. Guedes et al. 12285 (ALCB); Itabuna, maio 1983, E.B. Santos 14 (CEPEC, HUEFS); Itaête, $13^{\circ} 07^{\prime} \mathrm{S}$, $41^{\circ} 03^{\prime} \mathrm{W}$, abr. 2001, D.M. Loureiro et al. 127 (ALCB); Jacobina, $11^{\circ} 01^{\prime} 38^{\prime \prime S}, 40^{\circ} 33 ' 34^{\prime W}, 622$ m s.n.m., jul. 1996, R.M. Harley et al. PCD 3446 (ALCB); Licínio de Almeida, 1441'34"S, 42³1'53"W, 785 m, maio 2013, M. Alves et al. 167 (ALCB, HUEFS); Mata de São João, ago. 2013, A.M. Miranda \& R. Barros 6647 (HUEFS); Morpará, $11^{\circ} 35^{\prime} 51^{\prime \prime S}, 43^{\circ} 16^{\prime} 53^{\prime \prime W}, 394$ m s.n.m., jun. 2007, A.A. Conceição et al. 2295 (HUEFS); Morro do Chapéu, $11^{\circ} 33^{\prime} \mathrm{S}$, 41 ${ }^{\circ} 09^{\prime} \mathrm{W}, 1000$ m s.n.m., fev. 2013, M. Alves et al. 137 (ALCB,

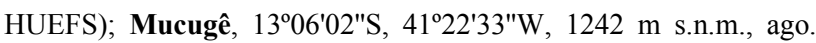
2014, M. Alves et al. 335 (HUEFS); Nova Itarana, mar. 1979, L.R.

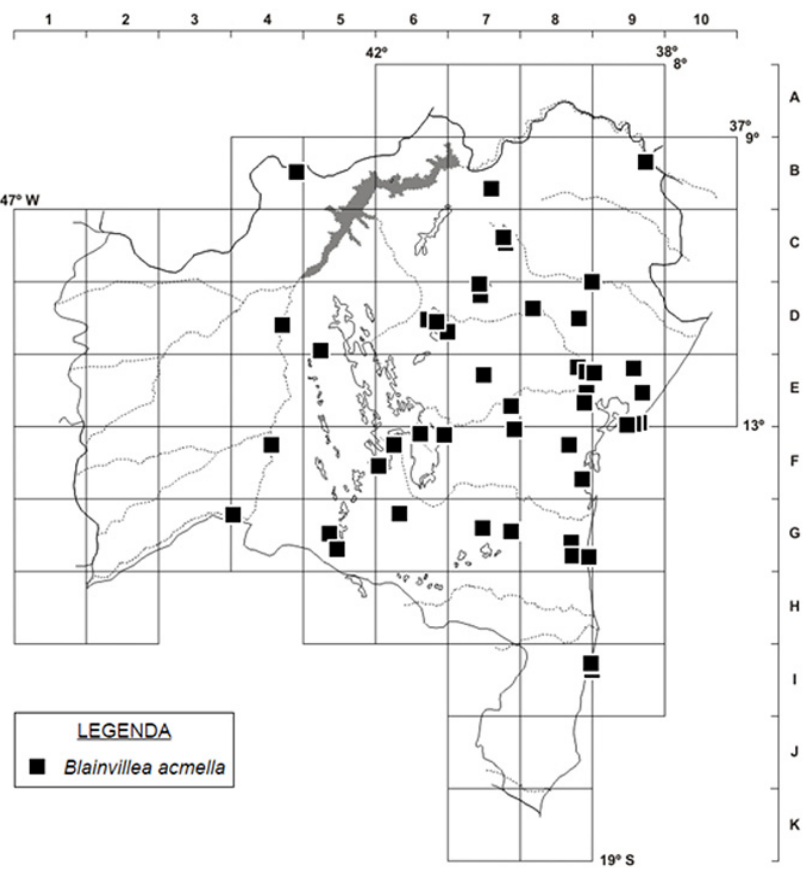

Figura 16. Mapa de distribuição geográfica de Blainvillea acmella no estado da Bahia. 

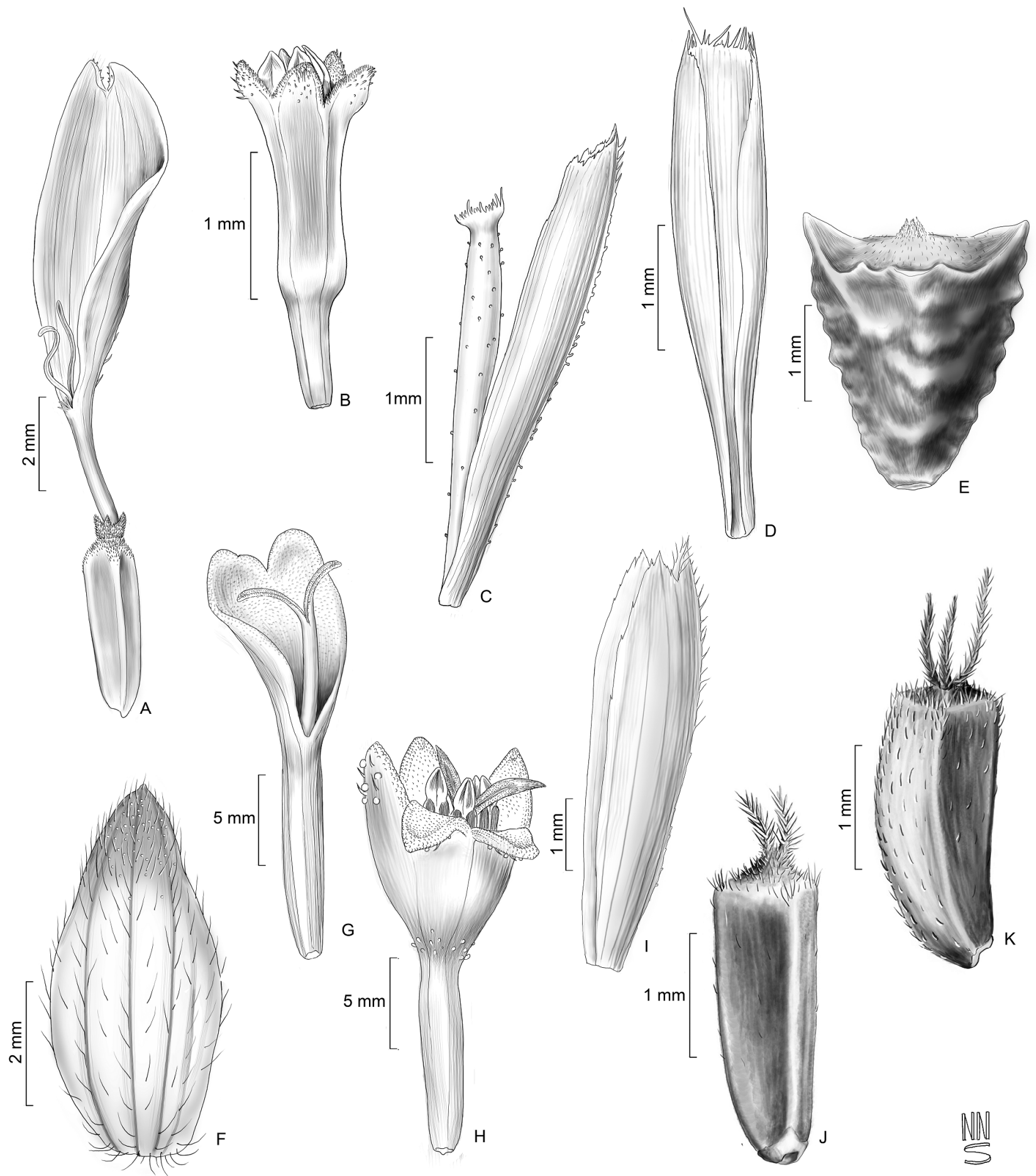

Figura 17. A-E. Baltimora geminata: A- flor feminina do raio; B- corola da flor funcionalmente masculina; C- ovário estéril da flor funcionalmente masculina e pálea; D- pálea; E- cipsela tríquetra. F-K. Blainvillea acmella: F- bráctea involucral estriada; G- corola da flor feminina do raio; H- corola da flor bissexuada do disco; I- pálea; J- cipsela da flor do raio; K- cipsela da flor do disco. (A- E- Queiroz 5966; F- K-Alves 335).

Noblick 1010 (ALCB); Poções, 14²4'00"S, 40³1'00"W, jan. 2009, P.D. Carvalho et al. 436 (HUEFS); Riachão do Jacuípe, $09^{\circ} 42^{\prime} 01 " \mathrm{~S}$, 40²3'20"W, mar. 2000, G. Cavalcanti et al. 37 (ALCB, HUEFS); Rio de Contas, $13^{\circ} 32^{\prime} \mathrm{S}, 41^{\circ} 57^{\prime} \mathrm{W}$, jan. 2000, A.M. Giulietti \& R.M. Harley 1655 (HUEFS); Ruy Barbosa, jul. 1975, A. Queiroz s.n. (ALCB 21575); Salvador, maio 2012, M. Alves 100 (ALCB); Santa Cruz Cabrália, $16^{\circ} 16^{\prime} \mathrm{S}, 39^{\circ} 01^{\prime} \mathrm{W}$, nov. 2000, M.L. Guedes 7561 (ALCB); Santo Estevão, 12²9'36"S, 39²0'13", 180 m s.n.m., jul. 2013, M. Alves 252 (ALCB, HUEFS); Senhor do Bonfim, $10^{\circ} 22^{\prime} 50^{\prime \prime S}, 40^{\circ} 13^{\prime} 31^{\prime \prime W}, 560 \mathrm{~m}$ s.n.m., jul. 2005, V.J. Santos et al.

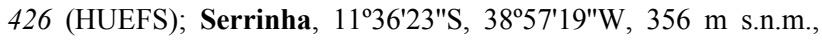
ago. 2008, J.M. Gonçalves et al. 233 (HUEFS).

Aparentemente, as duas espécies de Blainvillea registradas para o Brasil, $B$. dichotoma (Murray) Stewart e $B$. acmella, não apresentam características suficientes para diferenciá-las e, possivelmente, tratamse de uma mesma espécie com grande plasticidade fenotípica. 


\section{Calyptocarpus Less.}

Ervas ou arbustos. Folhas opostas; lâmina ovada ou lanceolada. Capítulos radiados, terminais ou axilares, solitários ou em cimeiras; brácteas involucrais em 1 ou 2 séries, oblongas, subiguais, foliáceas; receptáculo convexo, paleáceo. Flores do raio femininas; corola do raio verdadeira, inconspícua, amarela. Flores do disco bissexuadas; corola tubulosa, amarela; anteras enegrecidas, apêndices do conectivo com tricomas glandulares; ramos do estilete agudos. Cipselas obovoides ou oblanceoloides, às vezes compressas; pápus com 2-5 aristas eretas, às vezes divergentes ou reflexas.

Calyptocarpus pode ser reconhecido pelas brácteas involucrais em 1 ou 2 séries, foliáceas, flores do raio com corola inconspícua amarela e cipselas com pápus 2-5-aristado. Compreende duas espécies, que ocorrem nos Estados Unidos, México e América Central (Panero 2007) e uma espécie com registro para o Brasil (Nakajima et al. 2015).

7.1. Calyptocarpus brasiliensis (Nees \& Mart.) B.L.Turner, Phytologia 64(3): 214. 1988. Galophthalmum brasiliense Nees \& Mart., Nova Acta Phys.-Med. Acad. Caes. Leop.-Carol. Nat. Cur. 12(1): 8, t. 2.1824.

$=$ Calyptocarpus bahiensis Sch.Bip., Bot. Zeitung (Berlin) 24: 165. 1866.

Figura 18; Baker (1884: prancha 57).

Erva ou arbusto $0,3-1 \mathrm{~m}$ alt.; ramos cilíndricos a compressos, estriados, glabrescentes ou setosos. Folhas com pecíolo 0,5-1,3 cm compr.; lâmina 1-5,5 $\times$ 1,9-3,4 cm, membranácea, discolor, ovada ou elíptica, ápice agudo ou acuminado, margem serreada, base arredondada ou atenuada, setosa em ambas as faces. Capítulos axilares, 1-3 em cimeiras simples, 0,5-0,8 × 0,4-0,9 cm; pedúnculo 0,1-1 cm compr.; invólucro campanulado, brácteas involucrais subiguais, 4 ou 5, em 2 séries, 6-8 × 2,5-3,5 mm, lanceoladas ou ovadas, ápice agudo ou acuminado, margem inteira, setosas, verdes; receptáculo plano, páleas 3-5 × 0,5-1 $\mathrm{mm}$, lanceoladas, levemente conduplicadas, persistentes, ápice acuminado, às vezes eroso, margem inteira. Flores 10 ou 11. Flores do raio 4, 7-8 mm compr.; corola 4-5 mm compr. (tubo ca. $2 \mathrm{~mm}$ compr.), amarela. Flores do disco 5-7 mm compr.; corola tubulosa 3-4 mm compr. (tubo ca. $2 \mathrm{~mm}$ compr.), lacínias com a face abaxial setulosa, amarela; antera ca. 1,5 mm compr., apêndice do conectivo ca. $0,2 \mathrm{~mm}$ compr., ovado, ápice agudo, enegrecido, apêndice basal sagitado, filetes amarelos; estilete ca. 4 $\mathrm{mm}$ compr., amarelo, ramos do estilete ca. $1 \mathrm{~mm}$ compr., ápice agudo, pubescente. Cipselas ca. $4 \mathrm{~mm}$ compr., oblanceoloides, geralmente compressas, castanhas ou enegrecidas, glabrescentes ou pubescentes próximo ao ápice, carpopódio inconspícuo; pápus com 2-5 aristas de ca. $4 \mathrm{~mm}$ compr., às vezes com fímbrias entre as aristas.

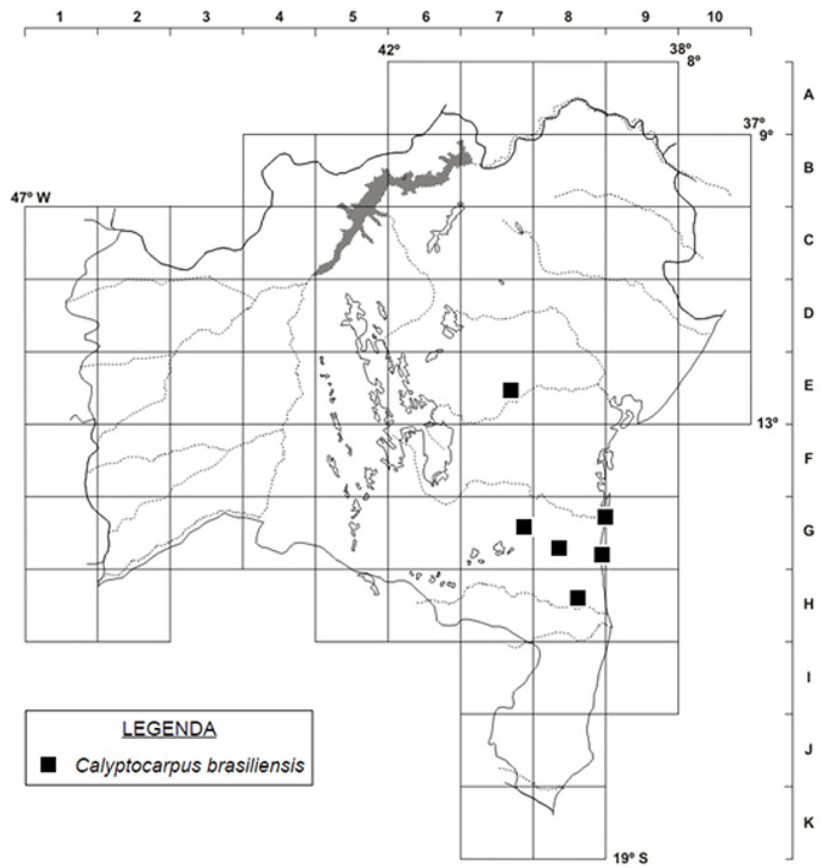

Figura 18. Mapa de distribuição geográfica de Calyptocarpus brasiliensis no estado da Bahia.

Ocorre na Argentina, Brasil, Paraguai e Uruguai (Mondin 2004). Najakima et al. (2015) cita a espécie para todas as Regiões, exceto o Nordeste; entretanto, Calyptocarpus bahiensis, citada para a Bahia desde Baker (1884), é sinônimo heterotípico de $C$. brasiliensis. E7, G7, G8, H8: áreas antropizadas. Encontrada com flores e frutos de junho a agosto.

Material selecionado - Almadina, jun. 1978, S. Mori et al. 10288 (RB); Boa Nova, $14^{\circ} 24^{\prime} 26^{\prime \prime} \mathrm{S}, 40^{\circ} 07^{\prime} 15^{\prime \prime} \mathrm{W}, 956$ m s.n.m., jun. 2013, L.Y.S. Aona et al. 1905 (ALCB); Camacã, 15²3'30"S, 39³3'55"W, 800-900 m s.n.m., jul. 2011, A.M. Amorim et al. 8022 (RB); Ilhéus, out. 1977, T.S. Santos 3152 (RB); Itaberaba, ago. 1974, G.C.P. Pinto 42409 (ALCB); Itacaré, jun. 1979, L.A. Mattos Silva et al. s.n. (RB 244609).

Calyptocarpus brasiliensis e C. biaristatus são comumente separadas pelo formato das cipselas (obpiramidal vs. compressa, respectivamente) e número de aristas (3 vs. 2) (Baker 1884). A análise de materiais coletados no Brasil, entretanto, mostrou que estas características variam entre os espécimes, sendo contínuas ao longo de sua distribuição geográfica. Desse modo, este trabalho corrobora o tratamento adotado por Mondin \& Magenta (2015), que considerou $C$. biaristatus como sinônimo heterotípico de $C$. brasiliensis, ainda que sua formalização não tenha sido publicada.

\section{Clibadium L}

Arbustos ou árvores pequenas. Folhas opostas; lâmina lanceolada ou amplamente ovada. Capítulos disciformes, terminais ou axilares, em glomérulos formando capitulescências cimosas, tirsoides ou paniculiformes; brácteas involucrais subiguais, em 2-6 séries, imbricadas, coriáceas, ovadas ou orbiculares; 
receptáculo plano ou convexo, paleáceo, páleas às vezes somente na base das flores femininas. Flores marginais femininas; corola tubulosa ou tubulosofiliforme, 2-4-laciniada, branca ou amarela. Flores do disco masculinas; corola tubulosa, 4- ou 5-laciniada, alva; anteras roxas ou enegrecidas, apêndice basal sagitado; ramos do estilete agudos ou acuminados nas flores femininas, estiletes indivisos, ovário estéril e linear nas flores masculinas. Cipselas obcompressas, obovoides ou obpiriformes, castanhas ou enegrecidas; pápus ausente, às vezes com duas aristas curtas ou tufos de tricomas curtos.

Clibadium é reconhecido pelo conjunto das seguintes características: arbustos ou árvores de pequeno porte, com capítulos laxamente agregados, brácteas involucrais membranáceas, em 2-6 séries, corola das flores femininas com 2-4 lacínias e das masculinas com 4 ou 5, e anteras roxas ou enegrecidas (Arriagada 2003). Abrange 24 espécies neotropicais (Panero 2007). No Brasil, ocorrem três espécies, apenas uma delas na Bahia (Nakajima et al. 2015).

8.1. Clibadium armanii (Balb.) Sch.Bip. ex O.E. Schulz, Bot. Jahrb. Syst. 46: 616. 1912. Eupatorium armanii Balb., Hort. Taur. Stirp. 27, t. 6.1810 .

= Clibadium rotundifolium DC., Prodr. 5: 505. 1836. Figura 19; Baker (1884: prancha 50).

Arbusto ca. 1-2 m alt.; ramos cilíndricos, estriados, estrigosos. Folhas com pecíolo 0,2-1,2 cm compr.; lâmina 4,3-9,3 × 2,3-6,4 cm, coriácea, discolor, ovada, ápice agudo ou acuminado, margem serreada, base arredondada, face adaxial estrigosa, a abaxial setulosa. Capitulescências tirsoides, sésseis ou curtopedunculadas (pedúnculo até $0,4 \mathrm{~cm}$ compr.). Capítulos 0,3-0,5 × 0,2-0,4 cm; invólucro ovoide, brácteas involucrais subiguais, 3, em 1 série, 4-5 × 3-4 $\mathrm{mm}$, ovadas, ápice mucronado, margem inteira, estrigosas, estriadas, alvas ou alvo-esverdeadas; receptáculo plano, páleas 4-5 × 1,5-3 $\mathrm{mm}$, ovadas, planas ou levemente côncavas, persistentes, ápice mucronado, margem inteira, pubescente na parte apical. Flores femininas 3 ou 4, 4,5-5,5 mm compr.; corola tubuloso-filiforme, 2-3 mm compr., lacínias e ápice do ovário pubescentes, alva; estilete ca. $3 \mathrm{~mm}$ compr., alvo, ramos do estilete ca. $2 \mathrm{~mm}$ compr., ápice agudo, pubescente. Flores masculinas 5-8, 5,5-6 mm compr.; corola ca. $2,5 \mathrm{~mm}$ compr. (tubo ca. $0,5 \mathrm{~mm}$ compr.); anteras ca. $2 \mathrm{~mm}$ compr., enegrecidas, apêndice do conectivo ca. 0,3 mm compr., lanceolado, ápice agudo, enegrecido, apêndice basal sagitado, filetes alvos. Cipselas ca. $3 \mathrm{~mm}$ compr., amplamente obovoides, enegrecidas, vilosas no ápice, carpopódio inconspícuo; pápus ausente.

Ocorre no Paraguai e no Brasil (Arriagada 2003), em todas as Regiões (Nakajima et al. 2015). D9, E9, F8, G8, H8, I8: mata atlântica. Encontrada com flores e frutos de agosto a maio.

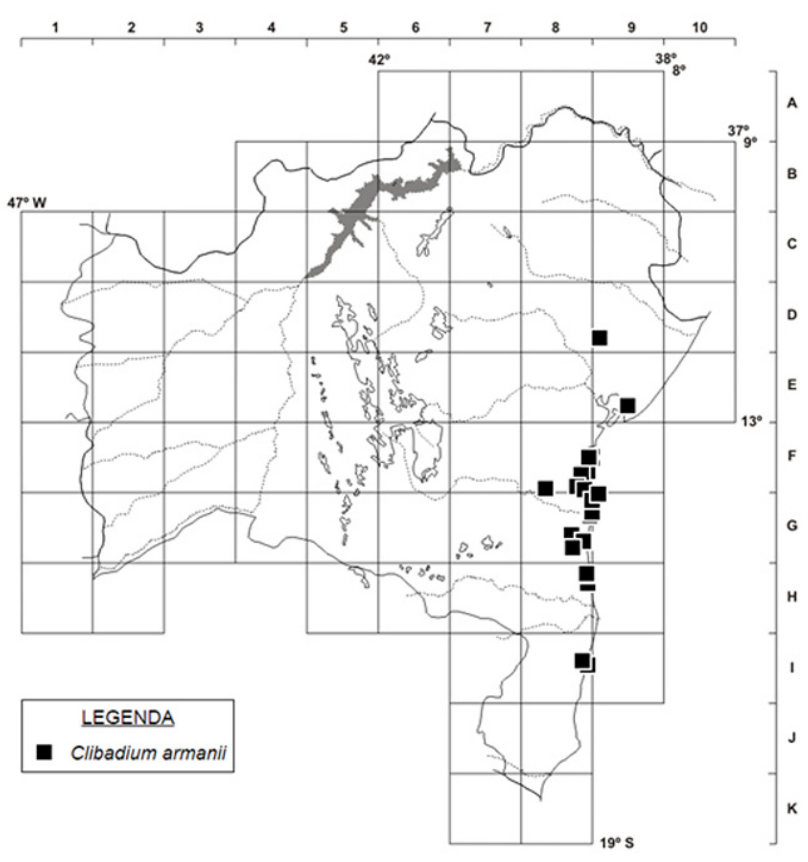

Figura 19. Mapa de distribuição geográfica de Clibadium armanii no estado da Bahia.

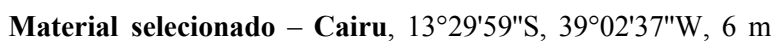
s.n.m., ago. 2008, L.P. Queiroz et al. 13742 (HUEFS); Camamu, jul. 2005, A.M. Miranda \& M.I. Silva 5135 (HUEFS); Candeias, $12^{\circ} 45^{\prime} 20^{\prime \prime S}, 38^{\circ} 30^{\prime} 10^{\prime \prime} \mathrm{W}, 9$ m s.n.m., maio 2011, M.L. Guedes et al. 18344 (ALCB); Igrapiúna, 135ㄴ'19"S, 39²12'28"W, 153 m s.n.m., jul. 2010, M.L. Guedes et al. 17295 (ALCB); Ilhéus, 14²41'S, 3907'W, jun. 2001, M.L. Guedes et al. 9399 (ALCB); Itabuna, jul. 1965, R. Belém 1258 (CEPEC); Itacaré, 1419'09"S, 3901'44"W, 149 m s.n.m., out. 2000, R.P. Oliveira et al. 700 (HUEFS); Ituberá, $13^{\circ} 43^{\prime} \mathrm{S}, 39^{\circ} 08^{\prime} \mathrm{W}$, jun. 2006, R.M. Valadão \& M.L. Guedes 390 (ALCB); Lamarão do Passé, jun. 1994, M.L. Guedes et al. 3263 (ALCB); Maraú, 1356'39"S, 29³8'56"W, 17 m s.n.m., maio 2009, M.L. Guedes et al. 15006 (ALCB); Nilo Peçanha, 13²41'31"S, $39^{\circ} 03^{\prime} 16^{\prime \prime} \mathrm{W}, 30 \mathrm{~m}$ s.n.m., ago. 2008, L.P. Queiroz et al. 13830 (HUEFS); Santa Cruz Cabrália, $16^{\circ} 23^{\prime} \mathrm{S}, 39^{\circ} 08^{\prime} \mathrm{W}, 40 \mathrm{~m}$ s.n.m., out. 1984, F. Souza Santos \& A. Euponino 418 (ALCB); Una, $15^{\circ} 09^{\prime} 35^{\prime \prime S}, 39^{\circ} 03^{\prime} 17^{\prime \prime} \mathrm{W}, 80 \mathrm{~m}$ s.n.m., maio 2004, A.M. Amorim \& R. Mascarenhas 4114 (ALCB).

Clibadium armanii é comumente identificada como C. rotundifolium DC., que se trata de um sinônimo (Arriagada 2003).

\section{Delilia Spreng.}

Ervas eretas ou decumbentes, anuais. Folhas opostas; lâmina ovada ou lanceolada. Capítulos radiados, em cimeiras umbeliformes, terminais ou axilares; brácteas involucrais 3(4), membranáceas, 1 circular maior e as outras suborbiculares, ovadas, obovadas ou elípticas; receptáculo inconspícuo, epaleáceo. Flores do raio femininas 1-3; corola do raio verdadeira, amarela, raramente alva. Flores do disco funcionalmente masculinas 1-3(4); corola tubulosa, 5laciniada, amarela, raramente branca; anteras enegrecidas, apêndice do conectivo com tricomas 
glandulares; estilete indiviso, ovário estéril. Cipselas obovoides, estriadas, compressas, biconvexas, glabras ou pubescentes; pápus ausente.

$\mathrm{O}$ gênero pode ser identificado pelo invólucro compresso com 3(4) brácteas foliosas, membranáceas, uma mais larga e maior, capítulos com 1 a 3 flores femininas (1 em Delilia biflora), com corola do raio verdadeira, e 1 a 3(4) flores masculinas (Delprete 1995). Abrange duas espécies, uma endêmica das Ilhas Galápagos e outra com distribuição na América tropical (Panero 2007).

9.1. Delilia biflora (L.) Kuntze, Revis. Gen. Pl. 1: 333. 1891. Milleria biflora L., Sp. Pl. 2: 919. 1753. Elvira biflora (L.) DC., Prodr. 5: 503. 1836 Figuras 20 e 27C; Baker (1884: prancha 46)

Erva ou arbusto $0,2-0,8 \mathrm{~m}$ alt.; ramos cilíndricos ou compressos, estriados, glabrescentes ou vilosos. Folhas com pecíolo $0,1-0,8 \mathrm{~cm}$ compr.; lâmina 3,26,5 × 1,4-3,1 cm, membranácea ou cartácea, discolor, ovada, ápice obtuso ou agudo, margem serreada, base arredondada ou atenuada, setulosas ou setosas em ambas as faces. Capitulescências em cimeiras umbeliformes, axilares ou terminais; pedúnculo 0,1$0,3 \mathrm{~cm}$ compr. Capítulos 0,4-0,6 $\times 0,4-0,6 \mathrm{~cm}$; invólucro circular, compresso, brácteas involucrais 3 , a maior 3-5 × 3-5 mm, circular, as 2 menores ca. $3 \times 2-$ 3 , elípticas, ápice mucronado, margem crenada, base cordiforme, foliáceas, verdes, pubescentes. Flor do raio 1 , ca. $2,2 \mathrm{~mm}$ compr.; corola ca. $1,5 \mathrm{~mm}$ compr. (tubo ca. $1 \mathrm{~mm}$ compr.), amarela; estilete ca. $1,5 \mathrm{~mm}$ compr., amarelo, ramos do estilete ca. $0,5 \mathrm{~mm}$ compr., ápice obtuso, glabro. Flor do disco 1, ca. 2,8 mm compr.; corola ca. $1,8 \mathrm{~mm}$ compr. (tubo ca. $1 \mathrm{~mm}$ compr.), amarela; antera ca. $0,5 \mathrm{~mm}$ compr., apêndice do conectivo ca. $0,1 \mathrm{~mm}$ compr., lanceolado, ápice obtuso, enegrecido, apêndice basal arredondado, adnato ao filete. Cipsela 2-3 mm compr., castanha a enegrecida, glabrescente, carpopódio inconspícuo.

Ocorre do México à Argentina (Delprete 1995); no Brasil, ocorre em quase todas as Regiões, exceto no Norte (Nakajima et al. 2015). B8, C7, C8, D7, D8, D9, E3, E7, E8, E9: áreas antropizadas. Encontrada com flores e frutos o ano todo.

Material selecionado - Anguera, $12^{\circ} 10^{\prime} 01^{\prime \prime} \mathrm{S}, 39^{\circ} 11^{\prime} 01^{\prime \prime} \mathrm{W}, 343$ m s.n.m., out. 2006, J.S. Novais et al. 35 (HUEFS); Cachoeira, $12^{\circ} 32^{\prime}$ S, 3905'W, 4-120 m s.n.m., jun-set. 1980, Grupo Pedra do Cavalo 368 (ALCB, HUEFS); Conceição do Coité, nov. 1986, L.P. Queiroz et al. 1105 (HUEFS); Cruz das Almas, jun. 1951, G.C.P. Pinto s.n. (ALCB 7183); Curaçá, 0905'35"S, 39³5'26"W, 455 m s.n.m., jun. 2011. E. Melo et al. 9871 (HUEFS); Feira de Santana, $12^{\circ} 15^{\prime} \mathrm{S}, 38^{\circ} 58^{\prime} \mathrm{W}$, jul. 1982, K.B. Britto 21 (ALCB, HUEFS); Ipecaetá, $12^{\circ} 20^{\prime} \mathrm{S}, 39^{\circ} 17^{\prime} \mathrm{W}$, ago. 1985, L.R. Noblick \& C. G. Lôbo 4336 (HUEFS); Inhambupe, set. 1975, E.F. Gusmão 222 (ALCB); Itaberaba, 12²5'13"S, 40³2'02"W, 559 m s.n.m., ago. 2005, L.P. Queiroz et al. 10737 (HUEFS); Jacobina, $11^{\circ} 08^{\prime} 35^{\prime \prime} \mathrm{S}, 40^{\circ} 30^{\prime} 08^{\prime \prime} \mathrm{W}, 888 \mathrm{~m}$ s.n.m., jul. 1996, D.J.N. Hind et al. PCD 3438 (ALCB, HUEFS); Miguel Calmon, $11^{\circ} 25^{\prime} \mathrm{S}, 40^{\circ} 36^{\prime} \mathrm{W}$, jun. 1985, L.R. Noblick 3882

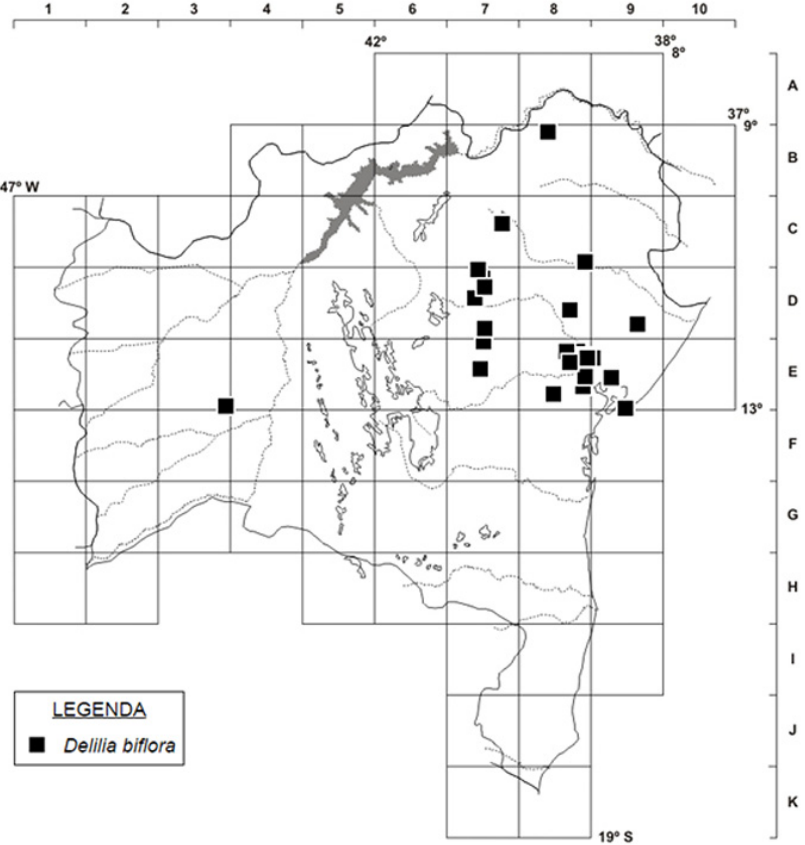

Figura 20. Mapa de distribuição geográfica de Delilia biflora no estado da Bahia.

(HUEFS); Mundo Novo, dez. 2006, A. Barreto 6 (ALCB); Quijingue, $10^{\circ} 55^{\prime} 20^{\prime \prime S}, 39^{\circ} 04^{\prime} 59^{\prime \prime} \mathrm{W}, 400-630 \mathrm{~m}$ s.n.m., jul. 2006, D. Cardoso \& T.M. Santana 1349 (HUEFS); Salvador, nov. 1975, B. Azevedo s.n. (ALCB 4511); Santana, $12^{\circ} 56^{\prime} 44^{\prime \prime} \mathrm{S}, 44^{\circ} 03^{\prime} 20^{\prime \prime} \mathrm{W}$, 663 m s.n.m., fev. 2000, L.P. Queiroz et al. 6007 (ALCB, HUEFS); Santa Teresinha, $12^{\circ} 46$ 'S, $39^{\circ} 31 \mathrm{~W}$, ago. 2013, M.L. Guedes et al. 20751 (ALCB); Santo Amaro, G.C.P. Pinto 355 (CEPEC); Senhor do Bonfim, $10^{\circ} 22^{\prime} 50^{\prime \prime S}, 40^{\circ} 13^{\prime} 31^{\prime \prime W}, 560$ m s.n.m., jul. 2005, V.J. Santos et al. 433 (HUEFS); Serra Preta, 12 $10^{\prime} \mathrm{S}, 39^{\circ} 20^{\prime} \mathrm{W}$, jul. 1985, L.R. Noblick \& Lemos 4148 (HUEFS).

No Brasil, D. biflora é quase sempre encontrada como erva daninha em campos de cultivo (Delprete 1995). Um dos primeiros registros da espécie no país, segundo o Species Link (2015), foi em 1832 no estado da Bahia (Blanchet 878 - NY).

\section{Dimerostemma Cass.}

Ervas ou arbustos eretos. Folhas opostas, eventualmente alternas próximas à inflorescência; lâmina amplamente ovada ou suborbicular. Capítulos radiados, terminais ou axilares, em dicásios laxos, raro solitários; brácteas involucrais em 3 ou 4 séries, as mais externas foliáceas; receptáculo convexo, paleáceo. Flores do raio femininas ou neutras; corola do raio verdadeira, amarela. Flores do disco bissexuadas; corola tubulosa, 5-laciniada, amarela; anteras castanhas ou enegrecidas, apêndice do conectivo estramíneo, deltado, glandular na face abaxial; ramos do estilete enrolados após a antese, às vezes glandulares, agudos ou acuminados, pilosos. Cipselas obovadas, às vezes tuberculadas e/ou aladas; as do raio geralmente trígonas, 3-aladas e 3-aristadas; as do disco geralmente achatadas, 2-aladas e 2aristadas; pápus coroniforme, com 2, 3 ou sem aristas. 
Dimerostemma se distingue dos outros gêneros da tribo principalmente pelas brácteas involucrais da série externa similares às folhas (Moraes \& Semir 2009). O gênero compreende 26 espécies com distribuição na Bolívia, Paraguai, Argentina e Brasil (Panero 2007). O Brasil é o centro de diversidade do gênero, com 22 espécies registradas, 12 delas endêmicas (Nakajima et al. 2015); destas, três ocorrem na Bahia, sendo duas com distribuição restrita ao estado.

\section{Chave para as espécies}

1. Lâmina foliar cartácea; flores do raio femininas; aristas do pápus, quando presentes, diminutas $(<0,1$ mm compr.) 10.1. D. bahiense

1'. Lâmina foliar coriácea; flores do raio neutras; aristas do pápus $1-3,5 \mathrm{~mm}$ compr.

2. Lâmina foliar com face adaxial estrigosa e abaxial vilosa ou tomentosa, bulada; páleas sem apêndice apical e com ápice arredondado; flores do raio 17 ou 18 10.2. D. episcopale

2'. Lâmina foliar com faces adaxial e abaxial setosas e glandulosas; páleas com apêndice apical triangular (ca. $1 \mathrm{~mm}$ compr.) e ápice agudo; flores do raio ca. 10 .. 10.3. D. lippioides

10.1. Dimerostemma bahiense (H.Rob.) M.D. Moraes, Phytologia 89: 117. 2007. Angelphytum bahiense H.Rob., Proc. Biol. Soc. Washington 97: 966. 1984.

Figura 21.

Arbusto ca. 1,5 m alt.; ramos cilíndricos, estriados, estrigosos. Folhas opostas; pecíolo 0,5-2,3 cm compr.; lâmina $4,5-11,8 \times 2-4,3 \mathrm{~cm}$, cartácea, discolor, lanceolada ou ovada, ápice acuminado, margem serreada, base atenuada, face adaxial estrigosa, esparso-glandulosa, a abaxial vilosa, estrigosa nas nervações, denso-glandulosa. Capitulescências em dicásios laxos; pedúnculo 0,7-11 cm compr. Capítulos 0,8-1,1 × 0,9-1,4 cm; invólucro campanulado, brácteas involucrais ca. 18 , em 2 séries, as externas 4-10 × 2,5$3 \mathrm{~mm}$, lanceoladas ou ovadas, ápice acuminado, margem serreada, ciliada, estrigosas, verdes, as internas ca. $4 \times 2 \mathrm{~mm}$, ovadas, ápice agudo, ciliado, margem inteira, amarelo-pálidas; páleas 5-6,2 × 2-3 $\mathrm{mm}$, elípticas, conduplicadas, persistentes, carenadas, com apêndice apical deltado (ca. $1 \times 1 \mathrm{~mm}$ compr.), ciliado, ápice agudo, margem inteira. Flores ca. 89. Flores do raio ca. 10, 15-19 mm compr., feminina; corola 13-16 mm compr. (tubo 1,5-2 mm compr., glabrescente), 2- ou 3-lobada. Flores do disco 6-7 mm compr.; corola 4-5 mm compr. (tubo ca. $1 \mathrm{~mm}$ compr.), amarela; anteras ca. $2 \mathrm{~mm}$ compr., apêndice do conectivo ca. 0,2 mm compr., triangular, ápice agudo ou obtuso, apêndice basal sagitado, filetes amarelos; estilete 4-5 mm compr., amarelo, ramos do estilete ca. $1 \mathrm{~mm}$ compr., ápice agudo. Cipselas isomorfas, 3-4 $\mathrm{mm}$ compr., obcompressas, estipitadas, lisas ou tuberculadas, oblanceoloides, castanhas ou enegrecidas, carpopódio inconspícuo; pápus com 2 aristas diminutas (menores que $0,1 \mathrm{~mm}$ compr.) e fímbrias erosas entre as aristas, sem aristas e com fimbrias ou com fímbrias fusionadas (pápus coroniforme).

Endêmica da Bahia (Moraes \& Semir 2009). E2, E3, F3, F4, G3, H9: cerrado. Encontrada com flores e frutos de fevereiro a junho.

Material selecionado - Belmonte, jun. 1999, M.L. Guedes et al. 6306 (ALCB); Cocos, mar. 2000, M.D. Moraes \& L.Y.S. Aona 447 (UEC); Coribe, $13^{\circ} 35^{\prime} 10^{\prime \prime} \mathrm{S}, 4^{\circ} 19^{\prime} 12^{\prime \prime} \mathrm{W}, 545 \mathrm{~m}$ s.n.m., abr. 2007, L.P. Queiroz et al. 12823 (HUEFS); Riacho de Santana, $13^{\circ} 27^{\prime} 44^{\prime \prime S}, 43^{\circ} 08^{\prime} 15^{\prime \prime} \mathrm{W}, 460$ m s.n.m., fev. 2000, L.P. Queiroz et al. 5925 (HUEFS); Santana, 1256'44"S, 4403'20"W, $663 \mathrm{~m}$ s.n.m., fev. 2000, L.P. Queiroz et al. 6003 (ALCB, HUEFS); São Desidério, $12^{\circ} 22^{\prime} 44^{\prime \prime S}, 44^{\circ} 57^{\prime} 12^{\prime \prime} \mathrm{W}, 570$ m s.n.m., abr. 2005, J.G. Carvalho-Sobrinho et al. 473 (HUEFS).

Conhecida até então apenas do município de Cocos, Dimerostemma bahiense teve aqui sua distribuição conhecida ampliada. Suas relações com Dimerostemma apense (Chodat) M.D.Moraes precisam ser melhor investigadas a fim de se verificar se representam realmente espécies distintas.

10.2. Dimerostemma episcopale (H.Rob.) H.Rob., Proc. Biol. Soc. Washington 97: 623. 1984. Oyedaea episcopale H.Rob., Phytologia 49: 276. 1981.

Figura 21, 23A-F e 27D.

Arbusto ca. 0,7-2 m alt.; ramos cilíndricos, estriados, tomentosos. Folhas opostas; pecíolo 0,1-1 cm compr.; lâmina 2,4-6,9(9,8) × 1,2-3(3,9) cm, coriácea, discolor, ovada, elíptica ou estreito-elíptica, ápice agudo ou acuminado, margem serreada, base atenuada ou decorrente, face adaxial estrigosa, a abaxial vilosa ou tomentosa, bulada. Capitulescências em dicásios laxos; pedúnculo 2,3-6 cm compr. Capítulos 1-1,4 × 1,3-1,8 cm; invólucro amplamente campanulado, brácteas involucrais 17-22, em 2 séries, as externas 6-20 × 2-8 mm, elípticas ou obovadas, ápice arredondado ou acuminado, margem inteira, face adaxial estrigosa, a abaxial tomentosa, buladas, às vezes espatuladas e esquarrosas, verdes, as internas 5$7 \times 2-3 \mathrm{~mm}$, estreito-elípticas ou elípticas, ápice agudo, acuminado ou obtuso, glabrescente, ápice às vezes similares às brácteas involucrais externas em indumento, textura e cor, margem inteira, amareloclaras; páleas 6-7 × ca. $2 \mathrm{~mm}$, estreito-elípticas, conduplicadas, persistentes, carenadas, ápice arredondado, ciliado, às vezes sinuoso, margem inteira. Flores 117-129. Flores do raio 17 ou 18, 10-13 mm compr., neutras; corola 7-11 mm compr. (tubo 1-1,5 $\mathrm{mm}$ compr.), 3-lobada. Flores do disco 6-8 $\mathrm{mm}$ compr.; corola 3-4,5 mm compr. (tubo $1 \mathrm{~mm}$ compr.), amarela, castanha na maturidade; anteras ca. 2,1 mm compr., apêndice do conectivo 0,1 mm compr., ovado, ápice agudo ou obtuso, apêndice basal sagitado, filetes amarelos; estilete 3-4 $\mathrm{mm}$ compr., amarelo, ramos do estilete 1-1,3 $\mathrm{mm}$ compr., ápice agudo. Cipselas isomorfas, 4-5 $\mathrm{mm}$ compr., obcompressas, às vezes estipitadas, lisas ou tuberculadas, obovoides, 
glabrescentes ou estrigosas, castanhas ou enegrecidas, alas até $1 \mathrm{~mm}$ larg., castanhas, carpopódio inconspícuo; pápus com 2 aristas de 1-1,5 mm compr., fimbriado, às vezes fímbrias fusionadas (pápus coroniforme).

Endêmica da Bahia, na Chapada Diamantina (Moraes \& Semir 2009). D6, F5, F6, G5: campo rupestre. Encontrada com flores e frutos durante todo o ano.

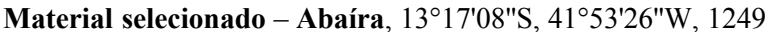
m s.n.m., fev. 2012, H.A. Ogasawara 193 (ALCB); Érico Cardoso


Harley et al. 26502 (ALCB, HUEFS); Piatã, 1306'24"S, $42^{\circ} 00^{\prime} 08^{\prime \prime W}, 1162$ m s.n.m., jun. 2014, M.L. Guedes et al. 21945

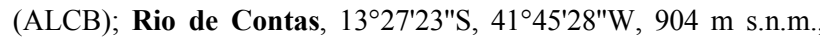
jul. 2014, M. Alves et al. 329 (ALCB, HUEFS).

Dimerostemma episcopale é a única espécie do gênero que ocorre na Chapada Diamantina. Pode ser reconhecida principalmente pela lâmina foliar coriácea, bulada.

10.3. Dimerostemma lippioides (Baker) S.F.Blake, Contr. Gray. Herb. 52: 15. 1917. Oyedaea lippioides Baker in Martius \& Eichler, Fl. Bras. 6(3): 208. 1884

Figura 21.

Arbusto ca. $1 \mathrm{~m}$ alt.; ramos cilíndricos, estriados, vilosos ou tomentosos. Folhas opostas; pecíolo 0,1-0,4 cm compr.; lâmina 2,4-3,7 × 1,2-3,1 cm, coriácea, discolor, elíptica ou ovada, ápice obtuso ou agudo, margem serreada, base arredondada, truncada ou atenuada, setosa e glandulosa em ambas as faces. Capitulescências em dicásios laxos; pedúnculo 0,7$7,5 \mathrm{~cm}$ compr. Capítulos 1-1,5 × 1,2-1,6 cm; invólucro campanulado, brácteas involucrais 16 ou 17 , em 2 séries, as externas $15-18 \times 6-8 \mathrm{~mm}$, ovadas ou elípticas, ápice agudo, margem serreada, setosas, verdes, as internas ca. $6 \times 2-3 \mathrm{~mm}$, oblongas, ápice agudo ou obtuso, ciliado, glabrescentes ou estrigosas na região central, amarelo-pálidas; páleas $7-8 \times$ ca. 2 $\mathrm{mm}$, estreito-elípticas, conduplicadas, persistentes, carenadas, com apêndice apical triangular (ca. $1 \mathrm{~mm}$ compr.), ápice agudo, margem inteira. Flores 129-131. Flores do raio ca. 10, 13-22 mm compr., neutras; corola 11,5-20 $\mathrm{mm}$ compr. (tubo 2-3 $\mathrm{mm}$ compr., pubescente), 2- ou 3-lobada, amarela. Flores do disco 7-8 mm compr.; corola ca. $5 \mathrm{~mm}$ compr. (tubo ca. 1 $\mathrm{mm}$ compr.), amarela; anteras ca. $2 \mathrm{~mm}$ compr., apêndice do conectivo ca. 0,5 mm compr., ovado, ápice agudo, apêndice basal sagitado, filetes amarelos; estilete 4,2-6 mm compr., amarelo, ramos do estilete 1-2 $\mathrm{mm}$ compr., ápice agudo. Cipselas 4-4,5 mm compr., obcompressas, levemente estipitadas, obovoides, alas inteiras até $1 \mathrm{~mm}$ larg., margem ciliada, castanhas, enegrecidas, carpopódio inconspícuo; pápus com 2 aristas de ca. 2,5-3,5 $\mathrm{mm}$ compr., pubescentes, e fimbrias às vezes fusionadas (pápus coroniforme).

Ocorre no Distrito Federal, Mato Grosso, Minas Gerais, São Paulo e Bahia (Moraes \& Semir 2009). E2, E3: cerrado. Encontrada com flores e frutos em janeiro.

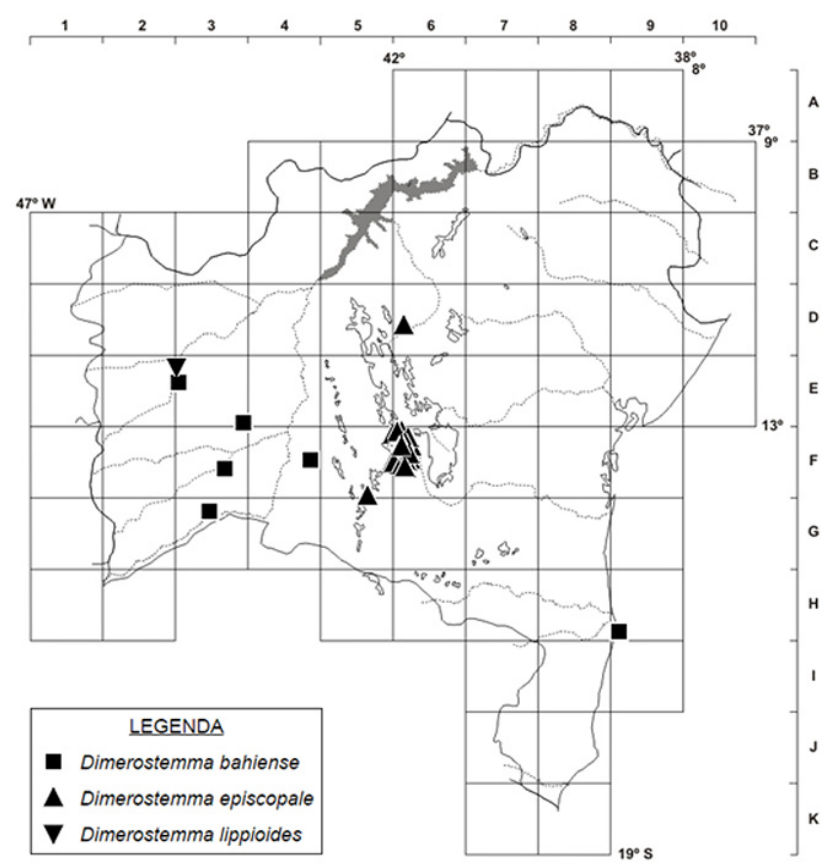

Figura 21. Mapa de distribuição geográfica de Dimerostemma bahiense, D. episcopale e D. lippioides no estado da Bahia.

Material selecionado - Barreiras, jan. 1978, A. Fernandes \& Matos 3645 (RB).

Material adicional examinado - BRASIL. GOIÁS: Aparecida de Goiânia, 1651'33"S, 49¹4'19"W, 906 m s.n.m., jan. 2007, J.B.F. Pastore 1717 (ALCB).

Dimerostemma lippioides possui a maior distribuição no país dentre as espécies do gênero encontradas na Bahia, ainda que possua registro apenas para o município de Barreiras no estado.

\section{Eclipta L.}

Ervas eretas ou decumbentes, anuais ou perenes. Folhas opostas; lâmina lanceolada, estreito-ovada ou ovada. Capítulos radiados, terminais ou axilares, solitários ou em cimeiras simples; brácteas involucrais subiguais, em 2 ou 3 séries, foliáceas; receptáculo plano ou convexo, com páleas filiformes. Flores do raio femininas; corola do raio verdadeira, linear, branca, esverdeada, amarela ou amarelo-pálida. Flores do disco bissexuadas; corola tubulosa, 4(5)-laciniada, branca ou amarela; anteras amarelas ou enegrecidas, apêndices do conectivo com ou sem tricomas glandulares; ramos do estilete acuminados. Cipselas geralmente compressas; as do raio às vezes triquetas e obcompressas, 3- ou 4-anguladas, obovoides a obpiramidais, tuberculadas ou rugosas, castanhoescuras, glabras, às vezes aladas ou com margem espessada; pápus coroniforme, às vezes com 2 projeções nos ângulos das cipselas, com ou sem 2 aristas fusionadas às alas.

Eclipta pode ser reconhecido por possuir flores do raio com corola linear e páleas filiformes (Panero 2007). Compreende cinco espécies, com distribuição na América e Austrália, tendo sido introduzida em 
outros continentes (Panero 2007). No Brasil, ocorre em todos os estados, sendo representada por três espécies (Nakajima et al. 2015), uma delas na Bahia.

\subsection{Eclipta prostrata (L.) L., Mant. Pl. 2: 286. 1771.} Verbesina prostrata L., Sp. Pl. 2: 902. 1753.

$=$ Eclipta alba (L.) Hassk., Pl. Jav. Rar.: 528. 1848. Verbesina alba L., Sp. Pl. 2: 902. 1753.

Figuras 22, 23G-J e 27E.

Arbusto, ereto ou prostrado, $0,2-0,8 \mathrm{~m}$ alt.; ramos cilíndricos, estriados, setulosos ou setosos. Folhas sésseis; lâmina 2,5-8,3 × 0,2-2,1 cm, cartácea, levemente discolor, linear, estreito-elíptica ou elíptica, ápice agudo ou acuminado, margem serreada, base cuneada, setulosa ou setosa em ambas as faces. Capítulos solitários ou 2 ou 3 fasciculados, no ápice ou na axila dos ramos; pedúnculo 0,9-7,5 cm compr. Capítulos 0,3-0,5 × 0,4-0,9 cm; invólucro subgloboso ou campanulado, brácteas involucrais 10 ou 11, em 2 séries, 2,5-4 × 1-1,5 mm, lanceoladas ou ovadas, ápice acuminado, margem inteira, verdes, setulosas; receptáculo plano, páleas $1,5-2 \mathrm{~mm}$ compr., persistentes, glabrescentes. Flores 159-179. Flores do raio ca. 154, em várias séries, 2,5-3 mm compr.; corola 1,2-2 $\mathrm{mm}$ compr. (tubo ca. 0,5 mm compr.), alva. Flores do disco ca. 2,5 mm compr.; corola ca. $1 \mathrm{~mm}$ compr. (tubo ca. 0,2 mm compr.), alva; anteras ca. 0,8 $\mathrm{mm}$ compr., enegrecidas, apêndice do conectivo ca. 0,1 $\mathrm{mm}$ compr., triangular, enegrecido, ápice obtuso ou agudo, apêndice basal sagitado, filetes alvos; estilete ca. $1 \mathrm{~mm}$ compr., alvo, ramos do estilete ca. $0,25 \mathrm{~mm}$ compr. Cipselas 2-2,5 $\mathrm{mm}$ compr., lisas ou tuberculadas quando maduras, obovoides, enegrecidas ou castanhas, glabras ou pubescentes no ápice, carpopódio inconspícuo; pápus coroniforme, fimbriado, menos que $0,5 \mathrm{~mm}$ compr., às vezes com lou 2 escamas de mesmo tamanho.

Apresenta distribuição pantropical (Mondin 2004) e ocorre em todos os estados brasileiros (Nakajima et al. 2015). B5, B7, C5, C7, C8, D5, D6, D7, D8, E4, E6, E7, E8, E9, F6, F7, F8, G8, I8: áreas antropizadas. Encontrada com flores e frutos durante todo o ano.

Material selecionado - Abaíra, $13^{\circ} 18^{\prime} \mathrm{S}, 4^{\circ} 48^{\prime} \mathrm{W}, 950-1000 \mathrm{~m}$ s.n.m., dez. 1992, D.J.N. Hind et al. H 50475 (HUEFS); Alagoinhas, mar. 1987, M.C. Peso et al. s.n. (ALCB 21930); Anguera, $12^{\circ} 10^{\prime S}$, $39^{\circ} 12^{\prime} \mathrm{W}, 200$ m s.n.m., fev. 1997, E. Melo et al. 2016 (ALCB, HUEFS); Barra do Mendes, $11^{\circ} 48^{\prime} 44^{\prime \prime}$ S, $42^{\circ} 05^{\prime} 24^{\prime \prime} \mathrm{W}, 720$ m s.n.m., out. 2009, E. Melo et al. 6829 (ALCB, HUEFS); Cachoeira, 12³2'S, 3905'W, 40-120 m s.n.m., maio 1980, Grupo Pedra do Cavalo 31 (ALCB, HUEFS); Caetité, 1350'27"S, 42¹6'21"W, J.L. Paixão et al. 1638 (HUEFS); Cairu, 1329'S, 3902'W, ago. 2006, M.G. Tosto et al. 64 (ALCB); Conceição do Coité, $11^{\circ} 30^{\prime} \mathrm{S}, 39^{\circ} 11^{\prime} \mathrm{W}$, set. 2013 , D.N. Carvalho 348 (HUEFS); Cruz das Almas, set. 1974, G.C.P. Pinto 42412 (ALCB); Entre Rios, $12^{\circ} 1$ 'S, 38 $02^{\prime} \mathrm{W}$, jul. 2011, A.V. Popovkin 897 (HUEFS); Feira de Santana, jun. 1982, M.J. Lemos 17 (ALCB, HUEFS); Iaçu, $12^{\circ} 43^{\prime} \mathrm{S}, 40^{\circ} 07^{\prime} \mathrm{W}$, mar. 1985, L.R. Noblick 3715 (HUEFS); Ilhéus, fev. 1986, J.L. Hage \& E.B. Santos 1943 (HUEFS); Irecê, $11^{\circ} 11^{\prime} \mathrm{S}, 41^{\circ} 55^{\prime} \mathrm{W}$, maio 2000, S. Bridgewater \& A.M. Giulietti 53939 (HUEFS); Itaparica, mar. 1975, A.L. Costa s.n.

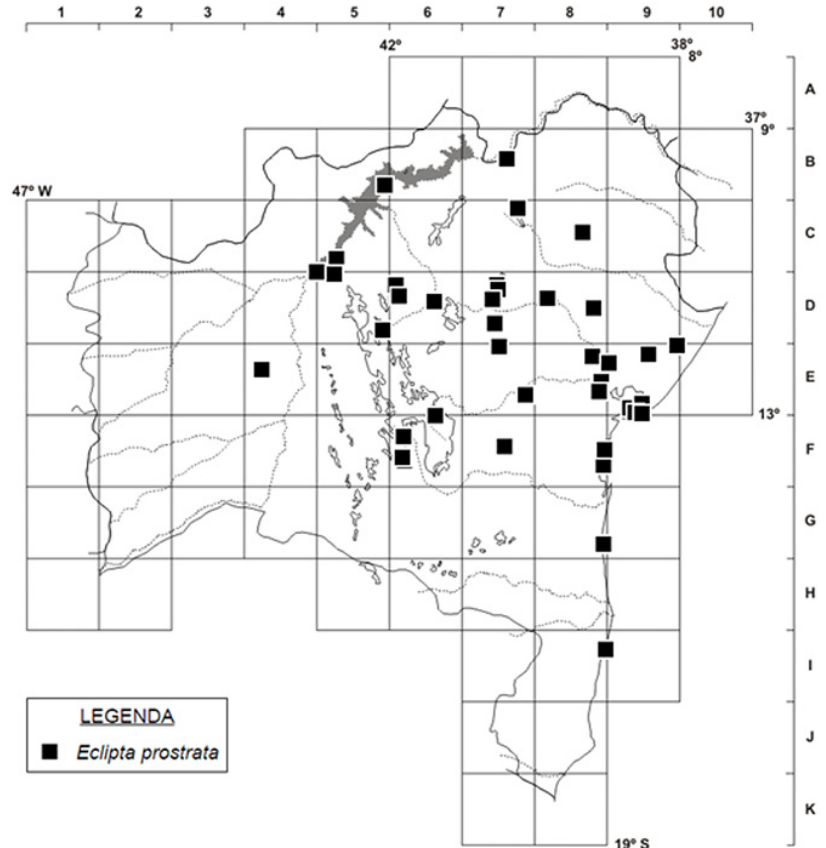

Figura 22. Mapa de distribuição geográfica de Eclipta prostrata no estado da Bahia.

(ALCB 4267); Jacobina, $11^{\circ} 14^{\prime} \mathrm{S}, 40^{\circ} 30^{\prime} \mathrm{W}$, jul. 1996, D.J.N. Hind PCD 3381 (ALCB, HUEFS); Jaguarari, 1006' $21^{\prime \prime} \mathrm{S}, 40^{\circ} 13^{\prime} 43^{\prime \prime} \mathrm{W}$, 546 m s.n.m., T.S. Nunes et al. 1253 (HUEFS); Juazeiro, 09²4'37"S, 40²2'58"W, 382 m s.n.m., set. 2009, E. Melo et al. 6420 (HUEFS); Lapão, $11^{\circ} 20^{\prime} 16^{\prime \prime S}, 41^{\circ} 51^{\prime} 26^{\prime \prime} \mathrm{W}, 765$ m s.n.m., abr. 2013, M.L. Guedes et al. 20683 (ALCB); Livramento de Nossa Senhora [Livramento do Brumado], $13^{\circ} 38^{\prime} \mathrm{S}, 41^{\circ} 47^{\prime} \mathrm{W}, 500-520 \mathrm{~m}$ s.n.m., nov. 1988, R.M. Harley et al. 25850 (ALCB); Malhada, 14²1'42"S, 434' 14"W, 450 m s.n.m., abr. 2001, J.G. Jardim et al. 3413 (ALCB, HUEFS); Maracás, $13^{\circ} 26^{\prime} \mathrm{S}, 40^{\circ} 25^{\prime} \mathrm{W}$, out. 2012, F.S. Gomes \& M.L.

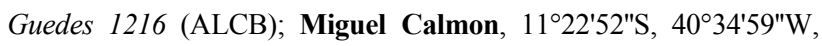
547 m s.n.m., dez. 2006, M.L. Guedes et al. 13214 (ALCB); Monte Santo, abr. 2000, R.P. Oliveira et al. 431 (HUEFS); Morro do

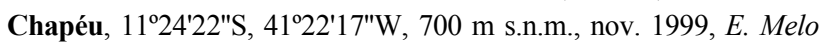
et al. 3153 (HUEFS); Mucugê, out. 2011, L. Moura 125 (ALCB); Mundo Novo, $12^{\circ} 02^{\prime} 00^{\prime \prime S}, 40^{\circ} 29^{\prime} 00^{\prime \prime} \mathrm{W}, 604$ m s.n.m., jul. 2006, P.A. Melo 89 (HUEFS); Nilo Peçanha, $13^{\circ} 41^{\prime} 41^{\prime \prime S}, 39^{\circ} 02^{\prime} 43^{\prime \prime} \mathrm{W}$, jul. 2010, M.L. Guedes et al. 17590 (ALCB); Paulo Afonso, maio 1981, H.P. Bautista 470 (HUEFS); Queimadas, $11^{\circ} 00^{\prime} \mathrm{S}, 43^{\circ} 00^{\prime} \mathrm{W}$, out. 1990, $A$. Freire-Fierro et al. 1904 (HUEFS); Riachão do Jacuípe, 11²2'S, 39² $9^{\prime}$ W, jul. 1985, L.R. Noblick \& Lemos 4019 (HUEFS); Rio de Contas, out. 1998, G. Hatschbach et al. 68445 (ALCB); Salvador, dez. 1991, M.L. Guedes \& D.J.N. Hind 17 (ALCB).; Santa Cruz Cabrália, $16^{\circ} 16^{\prime} \mathrm{S}, 39^{\circ} 01^{\prime} \mathrm{W}$, nov. 2000. L.M. Pacheco et al. 128 (ALCB); Sento Sé, 0946'52"S, 4203'43"W, 390 m s.n.m., dez. 2007, C. Correia et al. 368 (HUEFS); Vera Cruz, $12^{\circ} 57^{\prime} \mathrm{S}, 38^{\circ} 36^{\prime} \mathrm{W}$, set. 1999, M.L. Guedes 6429 (ALCB); Xique-xique, 1101'03"S, 42 ${ }^{\circ} 45^{\prime} 48^{\prime \prime W}, 527$ m s.n.m., jun. 1996, M.L. Guedes et al. PCD 3055 (ALCB).

Eclipta prostrata é nativa do Brasil (Nakajima et al. 2015). Os espécimes da Bahia possuem uma grande plasticidade fenotípica, variando em altura e tamanho das estruturas, mas a espécie pode ser facilmente reconhecida pela presença de páleas filiformes e cipselas tuberculadas sem pápus. 


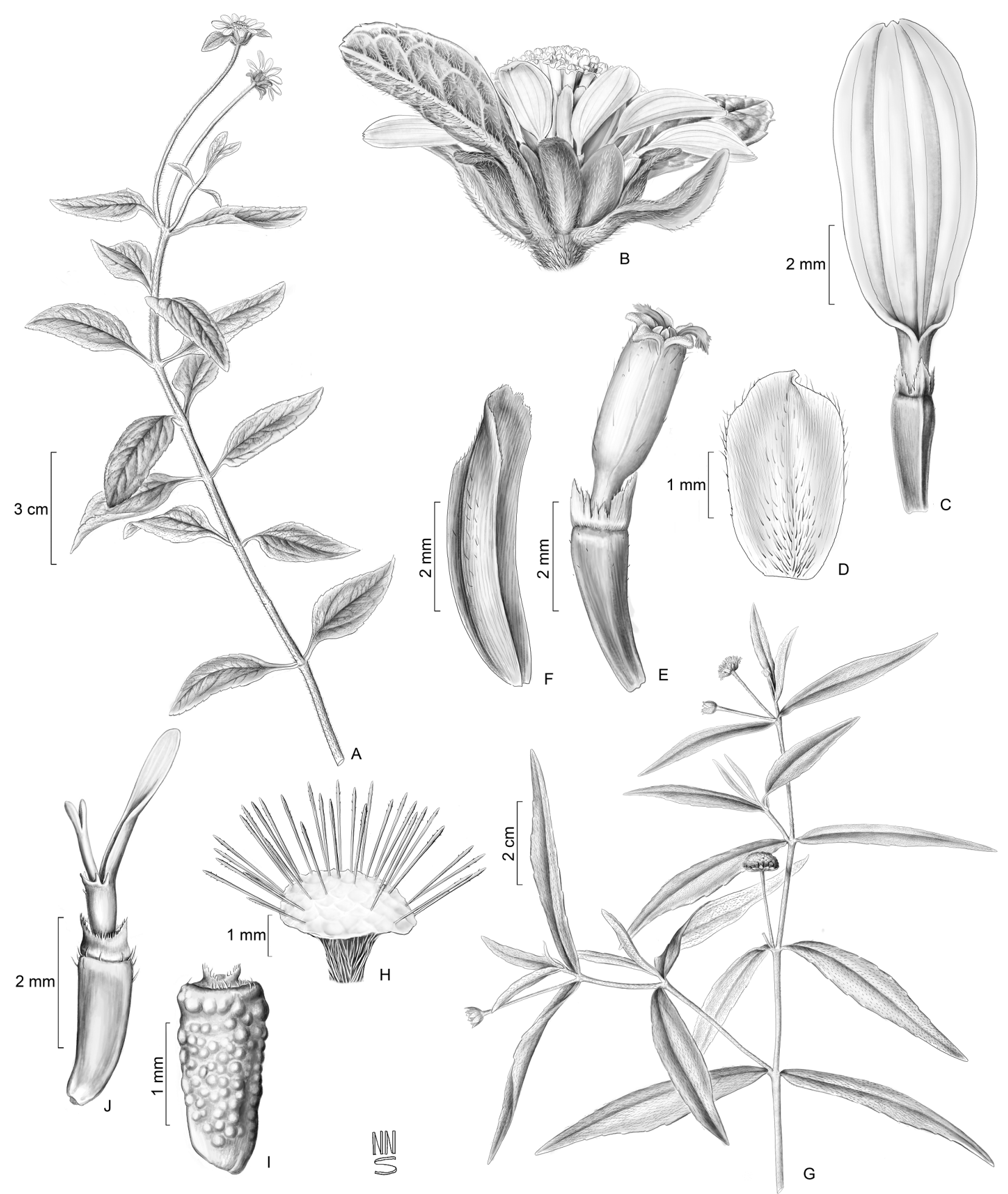

Figura 23. A-F. Dimerostemma episcopale: A- ramo com capítulos B- capítulo com brácteas involucrais externas similares às folhas; C- flor do raio; D- bráctea involucral; E- flor do disco; F- pálea conduplicada, carenada. G-J. Eclipta prostrata: G- ramo com capítulos; H- receptáculo com páleas filiformes; I- cipsela tuberculada; J- flor do raio com corola linear e pápus coroniforme. (A-F- Alves 329; G-J-Guedes 17)

\section{Eleutheranthera Poit.}

Ervas anuais, eretas ou arbustos. Folhas opostas; lâmina elíptica, ovada ou trulada. Capítulos radiados, discoides ou disciformes, axilares; brácteas involucrais em 1 série, foliáceas; receptáculo plano, paleáceo. Flores do raio neutras ou ausentes; corola do raio verdadeira, amarela ou amarelo-alaranjada. Flores do disco bissexuadas ou funcionalmente masculinas; corola tubulosa, amarela; anteras enegrecidas ou castanhas, apêndice do conectivo com tricomas glandulares; ramos do estilete agudos, ápice papiloso. Cipselas oblanceoloides ou obovoides, castanhas ou enegrecidas, tuberculadas; pápus coroniforme diminuto, ápice lacerado. 
Eleutheranthera pode ser reconhecido pelos capítulos com páleas lanceoladas ou ovadas, conduplicadas, de ápice acuminado, e cerca de três flores do disco bissexuadas e as outras funcionalmente masculinas, além das cipselas tuberculadas. Abrange duas espécies neotropicais, introduzidas em outras regiões tropicais (Panero 2007). No Brasil, ocorre somente uma espécie, com registros em todas as Regiões (Nakajima et al. 2015).

12.1. Eleutheranthera ruderalis (Sw.) Sch.Bip., Bot. Zeitung (Berlin) 24(21): 165. 1866. Melampodium ruderale Sw., Fl. Ind. Occid. 3: 1372. 1806.

Figuras $24,27 \mathrm{~F}$ e $31 \mathrm{~A}, \mathrm{~B}$.

Arbusto ca. $40 \mathrm{~cm}$ alt.; ramos cilíndricos ou compressos, estriados, setosos. Folhas com pecíolo $0,3-0,8 \mathrm{~cm}$ compr.; lâmina $1,7-2,5 \times 0,7-1,1 \mathrm{~cm}$, membranácea, levemente discolor, elíptica, raramente trulada, ápice agudo, margem crenada ou serreada, base atenuada, setosa e glandulosa em ambas as faces. Capítulos 1 ou 2, em cimeiras axilares, 0,4-0,5 × 0,5$0,9 \mathrm{~cm}$, disciformes; pedúnculo $0,2-1 \mathrm{~cm}$ compr.; invólucro campanulado, brácteas involucrais subiguais, 5, 4,5-7 × 2-3 mm, elípticas, setosas, glandulosas, ápice agudo ou obtuso, às vezes mucronado, margem inteira, verdes; páleas 3,5-4 × 1-2 mm, lanceoladas ou ovadas, conduplicadas, persistentes, com leve carena setosa, ápice acuminado, margem inteira, setosas. Flores $8-10$. Flores funcionalmente masculinas $3-8$, 3,5-4 mm compr.; corola ca. 2,5-3 mm compr. (tubo ca. $1 \mathrm{~mm}$ compr.), amarela. Flores bissexuadas 2 ou 3, ca. $4 \mathrm{~mm}$ compr.; corola ca. $2 \mathrm{~mm}$ compr. (tubo ca. 0,8 $\mathrm{mm}$ compr.); anteras ca. $1 \mathrm{~mm}$ compr., enegrecida, apêndice do conectivo ca. $0,05 \mathrm{~mm}$ compr., amplamente triangular, ápice agudo, enegrecido,

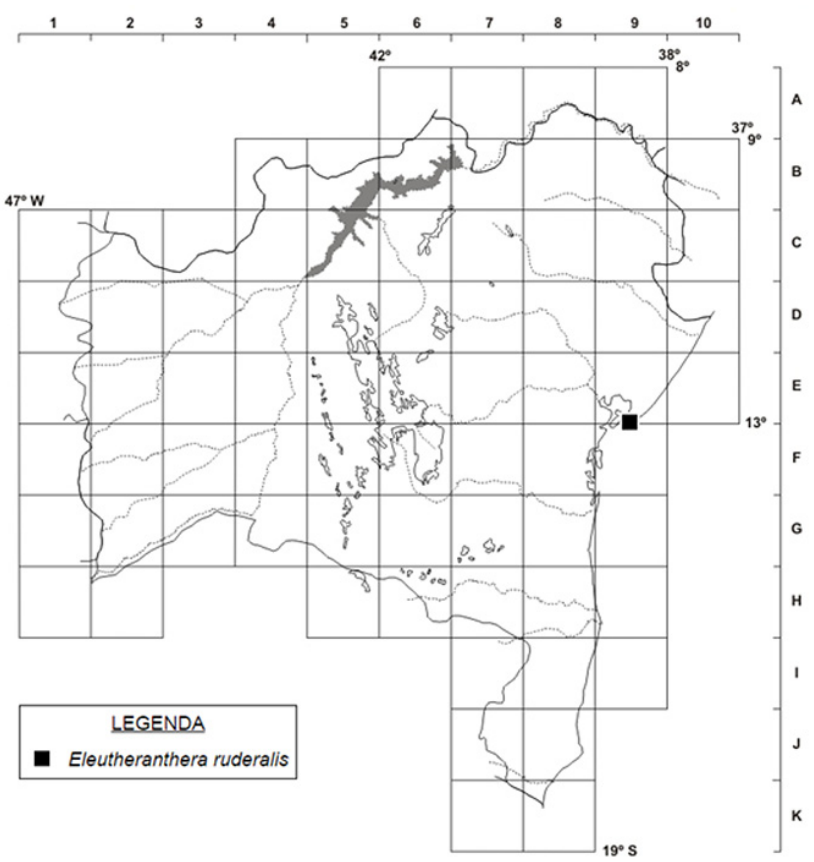

Figura 24. Mapa de distribuição geográfica de Eleutheranthera ruderalis no estado da Bahia. apêndice basal sagitado; estilete ca. $2 \mathrm{~mm}$ compr., amarelo, ramos do estilete ca. $1 \mathrm{~mm}$ compr., pubescentes. Cipselas 2-3 mm compr., oblanceoloides ou obovoides, compressas ou trigonais, pubescentes, carpopódio inconspícuo; pápus coroniforme, ca. 0,5 $\mathrm{mm}$ compr.

Ocorre em países da América Central, América do Sul e Ásia (Tropicos 2015). E9: áreas antropizadas. Encontrada com flores e frutos em dezembro.

Material examinado - Salvador, dez. 1991, M.L. Guedes \& D.J.N. Hind 2 (ALCB).

Eleutheranthera ruderalis pode ser confundida com Blainvillea acmella, Calyptocarpus brasiliensis ou Synedrella nodiflora devido às brácteas involucrais, porém o pápus coroniforme (vs. pápus com 2-5 aristas) permite diferenciá-la dessas espécies. No espécime analisado, foram encontrados capítulos disciformes, característica não citada anteriormente para o gênero.

\section{Helianthus L.}

Ervas eretas, anuais ou perenes. Folhas alternas, às vezes opostas; lâmina inteira. Capítulos radiados ou discoides, solitários ou em cimeiras paniculiformes; brácteas involucrais subiguais, em 2-5 séries; receptáculos planos ou convexos, paleáceos. Flores do raio neutras; corola do raio verdadeira, amarela. Flores do disco bissexuadas; corola tubulosa, amarela, amarelo-esverdeada ou avermelhada; anteras enegrecidas ou roxas; ramos do estilete às vezes com apêndices cilíndricos. Cipselas obovoides ou oblongas, enegrecidas ou castanho-acinzentadas, glabras ou pubescentes; pápus geralmente com 2 aristas ou 2 escamas maiores, às vezes com escamas entre elas, decíduo.

O gênero Helianthus é caracterizado pelo pápus de duas aristas ou escamas decíduas e outras escamas entre elas, decíduas ou ausentes (Heiser Jr. 1957). Compreende cerca de 50 espécies, distribuídas na América do Norte (Panero 2007). Na Bahia, é encontrada uma espécie cultivada.

\subsection{Helianthus annuus L., Sp. P1. 2: 904.1753.}

Figuras 25 e $27 \mathrm{G}$.

Nomes populares: girassol; chapéu-de-coro.

Erva ou arbusto $0,3-1,7 \mathrm{~m}$ alt.; ramos cilíndricos, estriados, glabrescentes ou vilosos. Folhas alternas; pecíolo 0,8-11,8 cm compr.; lâmina 3,9-25,7 × 0,9$18,5 \mathrm{~cm}$, cartácea, discolor, lanceolada, ovada ou amplamente ovada, ápice agudo ou acuminado, às vezes mucronado, margem serreada, base atenuada, arredondada ou truncada, face adaxial estrigosa ou setosa, a abaxial glabrescente, estrigosa ou setosa. Capítulos solitários, no ápice dos ramos, 1,2-2,2 × 0,9-6,2 cm, radiados; pedúnculo 0,7-3,4 cm compr.; invólucro campanulado ou subgloboso, brácteas involucrais $16-37$, em 2 ou 3 séries, $13-31 \times 4-14$ $\mathrm{mm}$, lanceoladas ou ovadas, ápice acuminado ou caudado, margem inteira, ciliada, verdes, estrigosas ou 
setosas na face abaxial; receptáculo plano, páleas 9-13 $\times 2-3 \mathrm{~mm}$, lanceoladas, conduplicadas, persistentes, com ou sem carena, ápice acuminado, margem inteira, às vezes ciliada próxima ao ápice, pubescente na face adaxial ou somente na carena. Flores 38-530. Flores do raio neutras, 8-23, 31,5-74 mm compr.; corola 26$67 \mathrm{~mm}$ compr. (tubo 2-2,5 mm compr., pubescente). Flores do disco 10-17 mm compr.; corola 6-8 mm compr. (tubo ca. $1 \mathrm{~mm}$ compr., pubescente), amarela; anteras 4-5 $\mathrm{mm}$ compr., enegrecidas, apêndice do conectivo 0,8-1 mm compr., ovado, amarelo, ápice obtuso, apêndice basal sagitado, filetes amarelos; estilete 7,5-9 mm compr., amarelo, ramos do estilete 2-3 mm compr., ápice agudo, pubescente. Cipselas 4$10 \mathrm{~mm}$ compr., oblanceoloides ou obovoides, castanhas ou enegrecidas, glabrescentes a pubescentes, carpopódio assimétrico; pápus com 2 escamas decíduas, ca. 2,5 mm compr.

Ocorre nas Américas, Ásia e África do Sul (Tropicos 2015), sendo cultivada no Brasil. E8, E9, G8: áreas antropizadas. Encontrada com flores e frutos de maio a julho.

Material selecionado - Feira de Santana, $12^{\circ} 15^{\prime} \mathrm{S}, 38^{\circ} 58^{\prime \prime} \mathrm{W}$, H. Andrade s.n. (ALCB 16545, HUEFS 3703); Ilhéus, $14^{\circ} 48^{\prime} \mathrm{S}$, $39^{\circ} 10^{\prime}$ W, 40 m s.n.m., jun. 1999, K. Sampaio et al. 03 (HUEFS); Itabuna, maio 1982, H.S. Brito 163 (UEC); Salvador, jul. 2012, M. Alves \& A. Stadnik 96 (ALCB).

Helianthus annuus é a espécie mais conhecida da tribo, sendo a mais importante economicamente, visto que é cultivada para extração de óleo das cipselas e flores para corte (Panero 2007). O início de sua domesticação data da era pré-hispânica, e ocorreu entre o México e os Estados Unidos, locais de ocorrência de suas prováveis variedades selvagens (Bye et al. 2009). Os espécimes encontrados na Bahia apresentaram grande plasticidade fenotípica.

\section{Lagascea Cav.}

Ervas, anuais ou perenes, ou arbustos. Folhas opostas; lâmina lanceolada, ovada, oblanceolada ou elíptica. Capítulos com 1 ou 2(8) flores, agregados em glomérulos, envolvidos por brácteas foliáceas, formando capítulos compostos de $1^{\mathrm{a}}$ e $2^{\mathrm{a}}$ ordem, discoides; brácteas involucrais subiguais, em 1 série, fusionadas formando um tubo; receptáculo convexo, epaleáceo. Flores bissexuadas; corola tubulosa, branca, rosada ou vermelha; anteras amarelas, castanhas, enegrecidas, rosadas ou vermelhas; ramos do estilete com ápice cônico e indumento na face abaxial. Cipselas biconvexas, oblanceoloides ou obovoides; pápus coroniforme de pequenas escamas laceradas, algumas das escamas dos ângulos da cipsela maiores ou ausentes.

Lagascea é o único gênero de Heliantheae que tem capítulos agregados, formando um capítulo composto (Syuessy 1976). Possui nove espécies com distribuição neotropical, tendo sido introduzida em outras regiões (Panero 2007). No Brasil, ocorre uma espécie com distribuição nos estados do Nordeste, Centro-Oeste e Sudeste (Nakajima et al. 2015).

\subsection{Lagascea mollis Cav., Anales Ci. Nat. 6(18):} 332; t. 44. 1803.

Figuras 25 e 27H; Baker (1884: prancha 45).

Arbusto, ca. $50 \mathrm{~cm}$ alt.; ramos compressos, estriados, setosos ou tomentosos, com tricomas glandulares esparsos. Folhas com pecíolo 1,2-2,9 cm compr.; lâmina 4,9-7,7 × 2-4,8 cm, cartácea, discolor, lanceolada ou ovada, ápice agudo ou acuminado, margem crenada ou serreada, base truncada ou atenuada, setosas em ambas as faces. Capítulos compostos ca. 30 flores; brácteas cartáceas, ca. 5, 3,5$9 \times 1,5-3 \mathrm{~mm}$, ovadas, verdes, setosas; receptáculo setuloso; capítulo unifloro, com invólucro cilíndrico, estriado, verde, setoso, formado por 5 brácteas involucrais de ápice acuminado fusionadas. Flores ca. $8 \mathrm{~mm}$ compr.; corola tubulosa, ca. 4,5 mm compr. (tubo ca. 1,2 mm compr., glabro), alva; anteras ca. 2 $\mathrm{mm}$ compr., enegrecidas, apêndice do conetivo ca. 0,3 $\mathrm{mm}$ compr., elíptico, enegrecido, apêndice basal sagitado, filetes alvos; estilete ca. 3,5 mm compr., alvo, ramos do estilete ca. $0,1 \mathrm{~mm}$ compr., ápice obtuso, papiloso. Cipselas ca. 3,1 mm compr., oblanceoloides, compressas, enegrecidas, pubescentes no ápice, glabrescentes; pápus coroniforme ca. $0,1 \mathrm{~mm}$ compr., ápice fimbriado.

Ocorre nos Estados Unidos, México, América Central, América do Sul e algumas localidades isoladas da África e Ásia (Stuessy 1978). F6, G6: caatinga e bordas de mata. Encontrada com flores e frutos em janeiro.

Material selecionado - Brumado, $14^{\circ} 10^{\prime} \mathrm{S}, 41^{\circ} 29^{\prime} \mathrm{W}$, jan. 2000, A.M. Giulietti \& R.M. Harley 1700 (HUEFS); Rio de Contas, jan. 2010, I.S. Abreu 96 (ALCB).

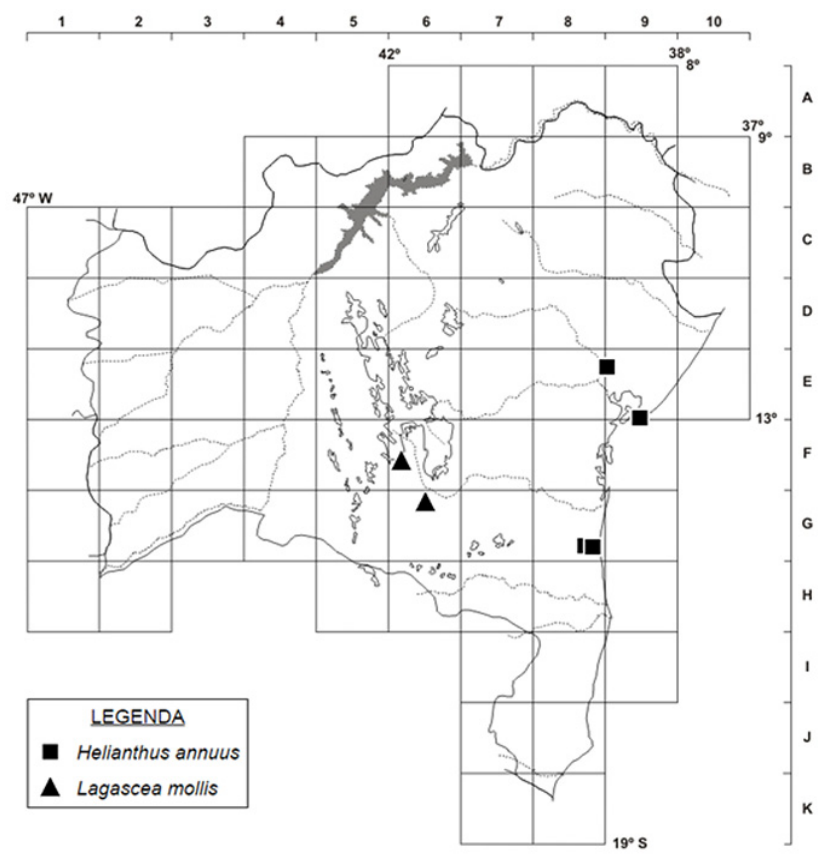

Figura 25. Mapa de distribuição geográfica de Helianthus annuus e Lagascea mollis no estado da Bahia. 

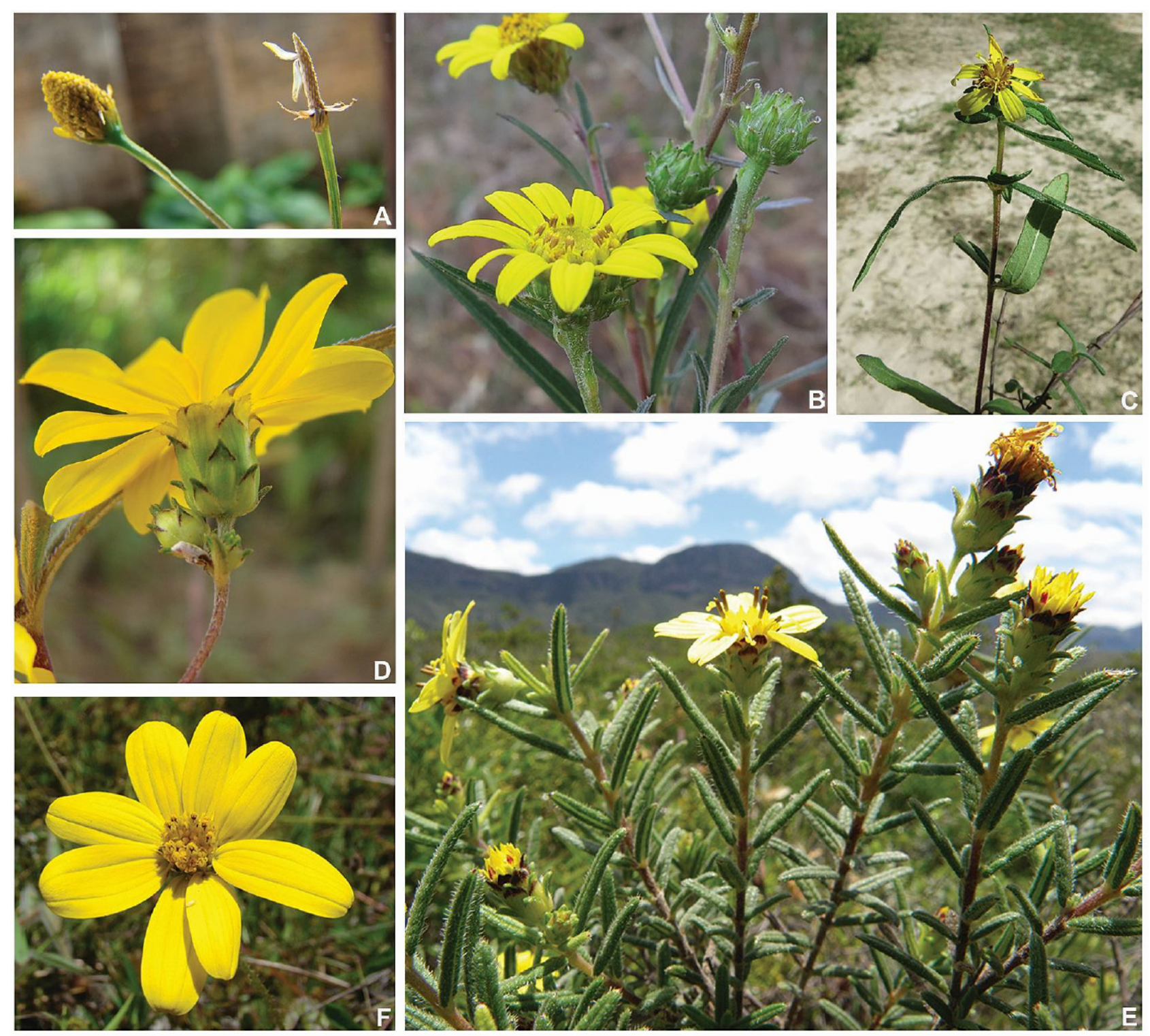

D
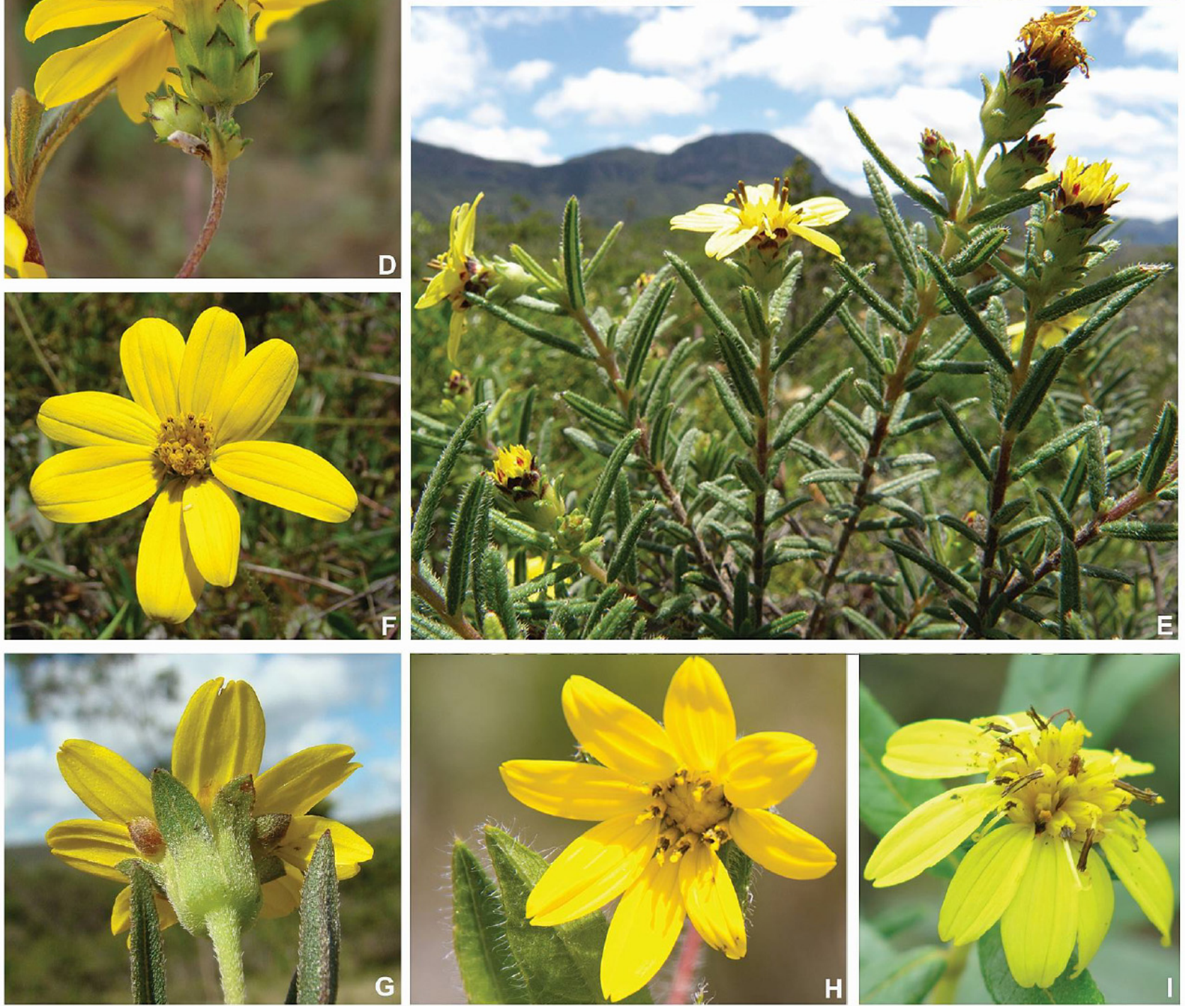

Figura 26. A. Acmella uliginosa: capítulo e receptáculo cônico com brácteas involucrais e páleas. B. Aldama bracteata: capítulo radiado. C. Aspilia egleri: ramo e capítulo. D. Aspilia floribunda: capítulo com brácteas involucrais gradativamente maiores. E. Aspilia foliosa: ramos e capítulos. F. Aspilia martii: capítulo radiado. G. Aspilia prostrata: capítulo com brácteas involucrais subiguais. H. Aspilia riedelii: capítulo radiado. I. Aspilia squarrosa: capítulo. (Fotos: A, H- Moura; B- Coelho; C, F- Alves; D, G, I- Roque, E- Ogasawara).

A capitulescência de Lagascea mollis pode ser confundida com um capítulo discoide com todas as flores tubulosas e bissexuadas; contudo, em uma análise mais acurada, percebe-se que as flores estão individualizadas por brácteas involucrais fusionadas e que o receptáculo da capitulescência é setuloso, características que permitem seu reconhecimento. 




Figura 27. A. Aspilia subalpestris: ramo com capítulo. B. Blainvillea acmella: capítulo radiado com brácteas involucrais com estrias verdes. C. Delilia biflora: capítulo. D. Dimerostemma episcopale: ramo com capítulos. E. Eclipta prostrata: ramo com capítulos. F. Eleutheranthera ruderalis: capítulo. G. Helianthus annuиs: capítulo com brácteas involucrais em 3 séries. H. Lagascea mollis: capítulo composto. (Fotos: A, C, F, H- Alves; B, E, G- Moura; D- Roque).

\section{Melanthera Rohr}

Ervas perenes, trepadeiras ou arbustos. Folhas opostas; lâmina ovada, deltada ou linear, às vezes trilobada ou pinada. Capítulos $1-3$, terminais ou axilares, radiados ou discoides; brácteas involucrais subiguais, em 1 ou 2 séries, oblongas ou estreitoovadas; receptáculo convexo, paleáceo. Flores do raio femininas, neutras ou ausentes; corola do raio verdadeira, 2- ou 3-lobadas, amarela. Flores do disco bissexuadas; corola tubulosa, branca ou amarela; 
anteras castanhas ou enegrecidas, apêndice do conectivo ovado, amarelo; ramos do estilete cônicos ou agudos, ápice levemente papiloso. Cipselas do raio obcompressas, obovoides ou obpiramidais, enegrecidas, ápice truncado, glabrescente, as do disco compressas, obcônicas ou iguais às do raio; pápus de cerdas decíduas.

Melanthera possui como principal característica diagnóstica o pápus cerdoso (Wagner \& Robinson 2001). Abrange 20 espécies e apresenta distribuição pantropical (Panero 2007). No Brasil, ocorre em quase todos os estados e é representado por duas espécies (Nakajima et al. 2015), uma delas na Bahia.

\subsection{Melanthera latifolia (Gardner) Cabrera, Darwiniana 16: 411. 1970. Echinocephalum latifolium Gardner, London J. Bot. 7: 294. 1848.} Figuras 28 e 35A; Baker (1884: prancha 69).

Arbusto 0,6-2 m alt.; ramos cilíndricos, estriados, setulosos ou setosos. Folhas com pecíolo $0,3-4 \mathrm{~cm}$ compr.; lâmina 4,8-10,1(15,1) × 1,2-6,3(11) cm, cartácea, discolor, lanceolada ou ovada, ápice acuminado ou caudado, margem denteada, base atenuada, face adaxial setulosa, a abaxial densosetulosa. Capítulos solitários ou 2 ou 3, fasciculados no ápice ou na axila dos ramos, $0,7-1,2 \times 0,9-1,2 \mathrm{~cm}$, radiados; pedúnculo 0,9-7,3 cm compr.; invólucro campanulado, brácteas involucrais 11 ou 12, em 2 séries, 4-5,5 × 1,5-2 mm, lanceoladas ou ovadas, ápice acuminado, margem inteira, verdes, setulosas; páleas 4-5 × 1-1,5 mm, lanceoladas, conduplicadas, persistentes, ápice setoso, margem inteira, setulosa na parte apical. Flores 53-55. Flores do raio 7-12, 8-11 mm compr.; corola 7-10 mm compr. (tubo ca. $1 \mathrm{~mm}$ compr., glabrescente), neutra. Flores do disco 4-5 mm compr.; corola 3-4 mm compr. (tubo ca. $1 \mathrm{~mm}$ compr., glabro), amarela; anteras ca. 2 mm compr., apêndice do conectivo ca. 0,5 mm compr., ápice agudo, apêndice basal sagitado, filetes amarelos; estilete ca. 3,5 mm compr., amarelo, ramos do estilete ca. 1,5 mm compr., ápice agudo, pubescente. Cipselas 2-3 $\mathrm{mm}$ compr., lisas, oblanceoloides ou obovoides, enegrecidas ou castanhas, glabrescentes ou pubescentes no ápice, carpopódio inconspícuo; pápus com cerdas de 1-2 mm compr.

Ocorre na Argentina, Bolívia, Paraguai e, no Brasil (Wagner \& Robinson 2001), em todas as Regiões (Nakajima et al. 2015). B4, B8, C7, D6, E, E8, E9: áreas antropizadas. Encontrada com flores e frutos durante todo o ano.

Material selecionado - Alagoinhas, mar. 1987, M.C. Peso et al. s.n. (ALCB 21927); Anguera, jun. 1997, E. Melo et al. 2293 (HUEFS); Cachoeira, $12^{\circ} 37^{\prime} \mathrm{S}, 38^{\circ} 57^{\prime} \mathrm{W}$, jul. 2006, M.L. Guedes et al. 12105 (ALCB); Campo Alegre de Lourdes, 09²9'16"S, 4305'22"W, 122 m s.n.m., abr. 2004, J.G. Carvalho-Sobrinho et al. 222 (HUEFS); Feira de Santana, 12 ${ }^{\circ} 13^{\prime} 30^{\prime \prime} \mathrm{S}, 39^{\circ} 00^{\prime} 43^{\prime \prime} \mathrm{W}, 316 \mathrm{~m}$ s.n.m., dez. 2013, M. Alves et al. 316 (ALCB, HUEFS); Ipecaetá, $12^{\circ} 20^{\prime} \mathrm{S}, 39^{\circ} 17^{\prime} \mathrm{W}$, ago. 1975, L.R. Noblick \& C.G. Lôbo 4345 (ALCB, HUEFS); Morro do Chapéu, jul. 1975, P. Pereira \& Y.
Brito s.n. (ALCB 19943); Salvador, maio 2011, M. Alves 27 (ALCB); Santo Estevão, 12 $29^{\prime} 36^{\prime \prime} \mathrm{S}, 39^{\circ} 20^{\prime} 13^{\prime \prime W}, 180$ m s.n.m., jul. 2013, M. Alves et al. 251 (ALCB, HUEFS); São Gonçalo dos Campos, abr. 1985, E.E.R. Oliveira 13 (HRB); Senhor do Bonfim, $10^{\circ} 21^{\prime} 55^{\prime \prime S}, 40^{\circ} 11^{\prime} 55^{\prime \prime} \mathrm{W}$, jul. 2005, T.S. Nunes et al. 1214 (HUEFS); Serra Preta, $12^{\circ} 10^{\prime} \mathrm{S}, 39^{\circ} 20^{\prime} \mathrm{W}$, jul. 1985, L.R. Noblick \& Lemos 4143 (HUEFS).

Melanthera latifolia é geralmente confundida em herbários com espécimes de Tilesia baccata, da qual se diferencia principalmente por possuir páleas com ápice setoso (vs. cuspidado em T. baccata) e pápus de cerdas decíduas (vs. pápus ausente).

\section{Parthenium L.}

Ervas ou arbustos. Folhas alternas; lâmina inteira ou dividida, geralmente ovada. Capitulescências corimbiformes ou paniculiformes. Capítulos radiados; brácteas involucrais 10, em 2 séries, dimórficas; receptáculo plano ou convexo, paleáceo. Flores do raio femininas 5; corola do raio verdadeira, alva ou alvoesverdeada. Flores do disco funcionalmente masculinas; corola tubulosa, 4- ou 5-laciniada, alva; anteras geralmente enegrecidas; ramos do estilete cilíndricos. Cipselas obcompressas, subtendidas por uma bráctea involucral associada a 2 flores do disco envolvidas por páleas; pápus com 2 ou 3 aristas, com ou sem escamas.

Parthenium pode ser reconhecido pelas dez brácteas involucrais em duas séries dimórficas e as cipselas subtendidas por uma bráctea involucral e associada a duas flores do disco envolvidas por páleas (Panero 2007). Compreende dezesseis espécies, distribuídas no continente americano (Panero 2007). No Brasil, são registradas duas espécies, e ocorre em todas as Regiões (Nakajima et al. 2015); uma espécie ocorre na Bahia.

\subsection{Parthenium hysterophorus L., Sp. Pl. 2: 988.} 1753.

Figuras 28 e $31 \mathrm{C}$.

Arbusto 0,5-1 $\mathrm{m}$ alt.; ramos cilíndricos ou compressos, estriados, estrigosos. Folhas com pecíolo 0,5-2,7 cm; lâmina 2,4-8,1 × 1,5-3,8 cm, cartácea, discolor, 1-5-lobada, pinatipartida, ápice agudo, margem inteira, base atenuada ou decorrente, estrigosas e glandulosas em ambas as faces. Capitulescências em cimeiras paniculiformes; pedúnculo $0,3-2 \mathrm{~cm}$ compr. Capítulos 1,6-3,1 $\times$ 2,1-4,1 $\mathrm{mm}$; invólucro campanulado, brácteas externas 5 , ca. $2 \times 1-1,5 \mathrm{~mm}$, ovadas, ápice obtuso ou agudo, margem inteira, verdes, estrigosas na parte apical, as internas 5 , ca. $2 \times 2 \mathrm{~mm}$, circulares, ápice arredondado, margem fimbriada, alvohialinas; receptáculo convexo, páleas ca. 1,5 ×0,5 mm compr., estreito-oblongas, conduplicadas, ápice truncado, fimbriado, margem inteira. Flores do raio 22,5 mm compr.; corola ca. 0,9 mm compr. (tubo ca. 0,3 $\mathrm{mm}$ compr., glabro), alva; estilete $0,5-1 \mathrm{~mm}$ compr., castanho, ramos do estilete $0,2-0,5 \mathrm{~mm}$ compr., ápice obtuso. Flores do disco ca. 50, 1-2 mm compr.; corola 


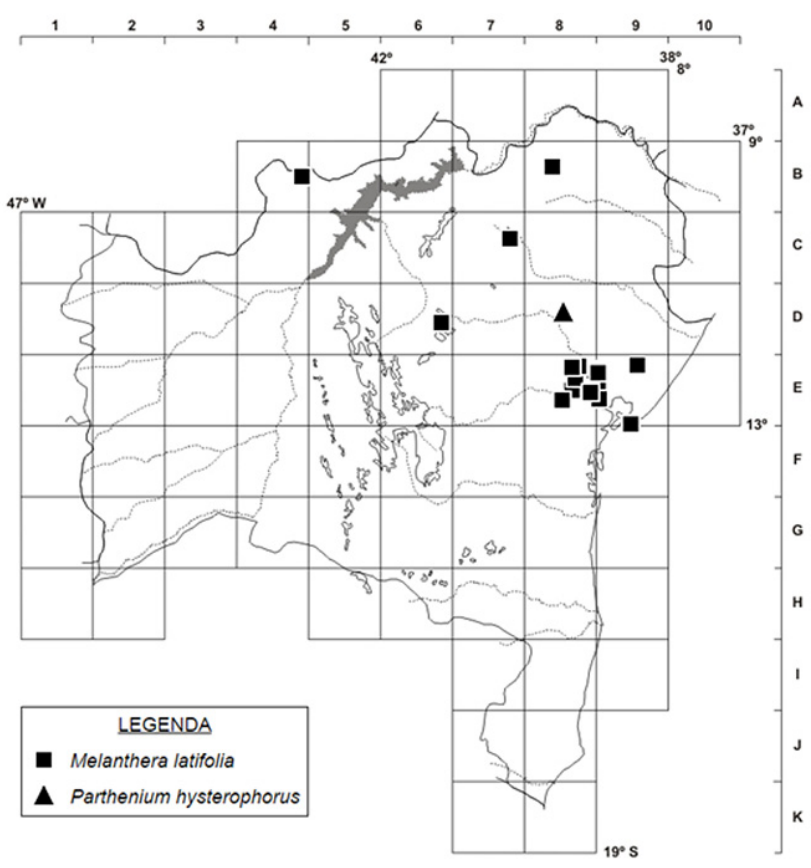

Figura 28. Mapa de distribuição geográfica de Melanthera latifolia e Pathenium hysterophorus no estado da Bahia.

1-1,5 mm compr. (tubo ca. 0,2 mm compr., glabro); anteras ca. $1 \mathrm{~mm}$ compr., enegrecidas, apêndice do conectivo ca. 0,1 mm compr., ovado, ápice obtuso, alvo, apêndice basal arredondado, filetes alvos. Cipselas ca. 2 mm compr., obovoides, enegrecidas, pubescentes, com 2 extensões no ápice, ca. 0,5 mm compr., subtendidas por uma bráctea involucral e duas flores do disco, carpopódio inconspícuo; pápus ausente.

Aparentemente nativa da América Central, tendo se tornado uma erva daninha amplamente distribuída em algumas regiões subtropicais e temperadas do mundo (Rollins 1950). No Brasil, ocorre em estados de todas as Regiões (Nakajima et al. 2015). D8: áreas antropizadas. Encontrada com flores e frutos em agosto.

Material examinado - Valente, ago. 1985, M.C. Peso 2 (ALCB).

Material adicional examinado - BRASIL. PERNAMBUCO: Bezerros, ago. 1996, A.M. Miranda et al. 2421 (ALCB).

Parthenium hysterophorus é naturalizada no Brasil (Nakajima et al. 2015), tendo um dos seus primeiros registros (Kuhlmann s.n. - MBM 69177; Species Link 2015) no ano de 1934, no estado de São Paulo.

\section{Riencourtia Cass.}

Ervas anuais ou arbustos perenes. Folhas opostas; lâmina linear, oblonga, ovada ou elíptica, 1-5-nervada. Capítulos disciformes, em glomérulos terminais com 5-9 flores; brácteas involucrais subiguais, 4, em 2 séries, oblongas, ovadas ou obovadas; receptáculo inconspícuo, epaleáceo. Flor feminina 1; corola tubuloso-filiforme, 4- ou 5-laciniada, alva. Flores masculinas 4-9; corola tubulosa, 4- ou 5-laciniadas, lacínias triangulares com longos tricomas tectores, alvas; anteras com apêndice basal sagitado; ramos do estilete papilosos nas flores femininas, estilete indiviso e ovário estéril nas funcionalmente masculinas. Cipselas ovoides, globosas ou obovoides, glabras ou pilosas no ápice; pápus ausente.

Riencourtia é reconhecido pelos capítulos disciformes, com receptáculo epaleáceo, 1 flor feminina e 5-9 masculinas, apresentando lacínias com longos tricomas tectores (Bringel Jr. 2014). Abrange quatro espécies, distribuídas no Panamá, Colômbia, Venezuela, Guiana, Suriname, Guiana Francesa, Bolívia e Brasil (Bringel jr. 2014).

\section{Chave para as espécies}

1. Folhas com pecíolo $0,1-0,3 \mathrm{~cm}$ compr.; lâmina $(0,4) 0,7-1,6$ cm larg., estreito-elíptica, margem plana, com três nervações evidentes

17.1. R. oblongifolia

1'. Folhas sésseis; lâmina $0,01-0,2 \mathrm{~cm}$ larg., linear, margem revoluta, apenas a nervação central evidente 17.2. R. tenuifolia

17.1. Riencourtia oblongifolia Gardner, London J. Bot. 7: 287. 1848.

$=$ Riencourtia angustifolia Gardner, London J. Bot. 7: 287. 1848.

Figura 29; Baker (1884: prancha 47).

Arbusto ca. 0,4-0,5 m alt.; ramos cilíndricos, estriados, estrigosos. Folhas com pecíolo $0,1-0,3 \mathrm{~cm}$ compr.; lâmina (3)4-7,4 × (0,4)0,7-1,6 cm, cartácea ou subcoriácea, levemente discolor, estreito-elíptica, ápice agudo, acuminado ou obtuso, margem inteira ou serreada, plana, base atenuada, setulosas ou estrigosas em ambas as faces, três nervações evidentes. Capitulescências com pedúnculo 0,8-25,6 cm compr.; brácteas da capitulescência 4,5-6 × 2-3 mm, ovadas, ápice mucronado, margem inteira, ciliada, estrigosas, alvo-esverdeadas. Capítulos ca. $5 \times 3-4 \mathrm{~mm}$; invólucro obovoide ou amplamente obovoide, brácteas involucrais 4-5 × 2-3 mm, ovadas ou elípticas, ápice mucronado, margem inteira, estrigosa na parte apical, alvas ou creme. Flor feminina ca. $4 \mathrm{~mm}$ compr.; corola ca. 2-3 mm compr.; estilete ca. 2,5 mm compr., alvo, ramos do estilete ca. 1,5 $\mathrm{mm}$ compr., ápice arredondado. Flores masculinas 6 ou 7, 3-4 $\mathrm{mm}$ compr.; corola 2-3 $\mathrm{mm}$ compr. (tubo ca. 0,3 $\mathrm{mm}$ compr.), lacínias setosas na face abaxial; anteras ca. 1,5 mm compr., enegrecidas, apêndice do conectivo ca. 0,2 $\mathrm{mm}$ compr., triangular, ápice obtuso, enegrecido, filetes alvos. Cipselas ca. $4 \mathrm{~mm}$ compr., amplamente obovoides, enegrecidas, glabrescentes ou setosas, ápice setoso ou tomentoso, carpopódio inconspícuo.

Ocorre na Bolívia e no Brasil, com registros para BA, DF, GO, MA, MT, MG, PA, SP e TO (Bringel Jr. 2014). D2, G5: áreas antropizadas ou cerrado. Encontrada com flores e frutos de fevereiro a março.

Material examinado - Formosa do Rio Preto, $11^{\circ} 03^{\prime} 34^{\prime \prime} \mathrm{S}$, 45 $16^{\prime} 17^{\prime \prime W}, 480$ m s.n.m., mar. 2000, E.B. Miranda Silva et al. 379 (ALCB, HUEFS); Licínio de Almeida, 1441'33"S, 42³1'52"W, 783 m s.n.m., fev. 2012, M. Alves 97 (ALCB). 
Bringel Jr. (2014) citou Riencourtia oblongifolia para o estado da Bahia, mas não indicou materiais comprobatórios, o que foi feito pela primeira vez por Alves et al. (2015). Apesar de análises moleculares sugerirem que $R$. oblongifolia e $R$. tenuifolia sejam a mesma espécie (Bringel Jr. 2014), e de alguns espécimes de $R$. oblongifolia encontrados na Bahia apresentarem a lâmina foliar mais estreita (ca. $0,4 \mathrm{~cm}$ compr.), tornando confusa a separação entre essas espécies, o conceito adotado neste trabalho foi o de Bringel Jr. (2014). A característica de três nervações evidentes em $R$. oblongifolia (vs. apenas uma em $R$. tenuifolia) se mostrou consistente para separar essas espécies na Bahia.

17.2. Riencourtia tenuifolia Gardner, London J. Bot. 7: 287.1848

Figuras 29 e 35B.

Arbusto 0,6-1,5 m alt.; ramos cilíndricos, estriados, estrigosos. Folhas sésseis ou curto-pecioladas (pecíolo até $0,1 \mathrm{~cm}$ compr.); lâmina 2-8 $\times 0,01-0,2 \mathrm{~cm}$, coriácea, levemente discolor, linear, ápice agudo ou acuminado, margem inteira, revoluta, base cuneada, estrigosa em ambas as faces, uma nervação evidente. Capitulescências com pedúnculo $2-11,7 \mathrm{~cm}$ compr.; brácteas 5-5,5 × 1,5-2 mm, lanceoladas ou ovadas, ápice mucronado, margem inteira, estrigosas, verdes ou alvas. Capítulos 5-6 × 2-3 mm; invólucro elipsoide ou obovoide, brácteas involucrais 3,5-4 × 1,5-2 mm, ovadas, ápice mucronado, margem inteira, alvas. Flor feminina 3-4 mm compr.; corola ca. $2 \mathrm{~mm}$ compr., lacínias setosas; estilete ca. $2 \mathrm{~mm}$ compr., alvo, ramos do estilete ca. 1,1 $\mathrm{mm}$ compr., ápice arredondado. Flores masculinas 6 ou 7 , ca. $4 \mathrm{~mm}$ compr.; corola $2-3 \mathrm{~mm}$ compr. (tubo ca. 0,2 $\mathrm{mm}$ compr.), lacínias setosas; anteras ca. $1,5 \mathrm{~mm}$ compr., enegrecidas, apêndice do conectivo ca. $0,2 \mathrm{~mm}$ compr., triangular, ápice obtuso, enegrecido, filetes alvos. Cipselas ca. 3,5 $\mathrm{mm}$ compr., obovoides ou amplamente obovoides, castanhas ou enegrecidas, pubescentes no ápice, carpopódio inconspícuo.

Endêmica do Brasil, nos estados de GO, DF, BA, TO e PI (Bringel Jr. 2014). D2, E2, E3, E8, E9, F2, F3, F6, G2: cerrado. Encontrada com flores e frutos de janeiro a maio.

Material selecionado - Abaíra, $13^{\circ} 17^{\prime} \mathrm{S}, 41^{\circ} 48^{\prime} \mathrm{W}, 1150$ m s.n.m. fev. 1992, J.R. Pirani et al. H 51489 (HUEFS); Barreiras, 11³7'18"S, 4602'30"W, 764 m s.n.m., s.d., A. Cotrim et al. 1649 (HUEFS); Correntina, $13^{\circ} 31^{\prime} 09^{\prime \prime S}, 45^{\circ} 00^{\prime} 57^{\prime \prime} \mathrm{W}, 760 \mathrm{~m}$ s.n.m., fev. 2000, L.P. Queiroz et al. 6070 (ALCB, HUEFS); Formosa do Rio Preto, $11^{\circ} 06^{\prime} 50^{\prime \prime S}, 45^{\circ} 28^{\prime} 20^{\prime \prime} \mathrm{W}, 502 \mathrm{~m}$ s.n.m., maio 2009, L.P. Queiroz et al. 14492 (HUEFS); Ibicoara, 1318'05"S, 4132'40"W, 1155-1247 m s.n.m., fev. 2003, F. França et al. 4309 (ALCB, HUEFS); Jaborandi, $14^{\circ} 08^{\prime} 50^{\prime \prime S}, 45^{\circ} 50^{\prime} 07^{\prime \prime}, 870$ m s.n.m., maio 2001, F. França et al. 3719 (ALCB, HUEFS); Mucugê, 12²1'25"S, 38 55'54"W, $995 \mathrm{~m}$ s.n.m., jan. 2012, M. Alves \& H.A. Ogasawara 46 (ALCB); Piatã, 1304'19"S, 41²7'33"W, 1240 m s.n.m., nov. 1996, D.J.N. Hind \& H.P. Bautista PCD 4193 (ALCB, HUEFS); São Desidério, 12²1'S, 445'ㄴ, mar. 2002, D.M. Loureiro et al. 571 (ALCB).

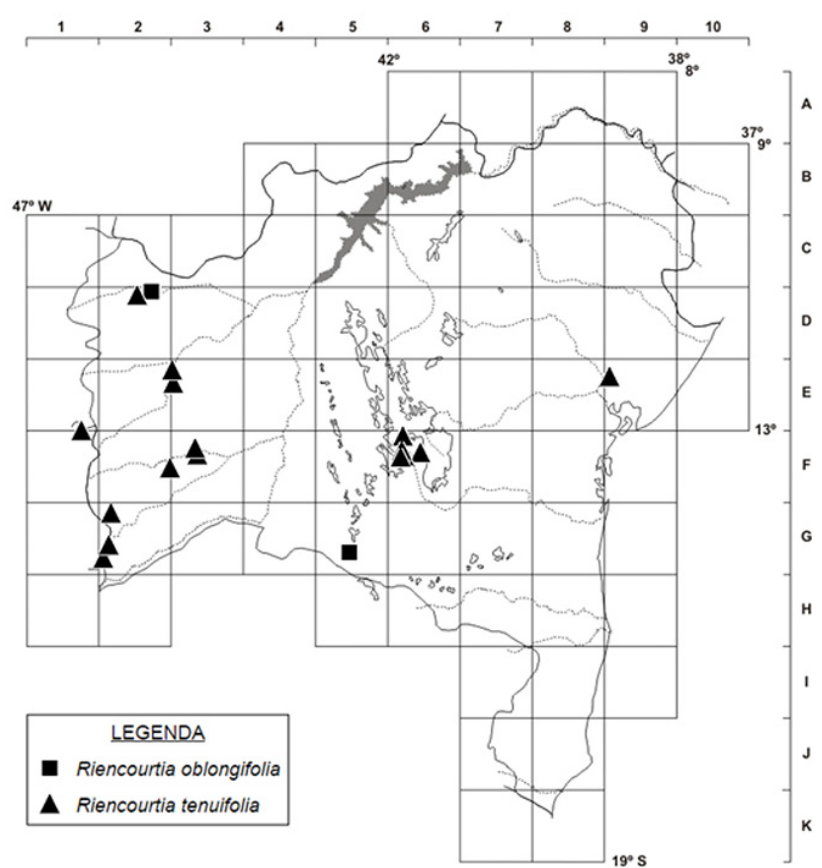

Figura 29. Mapa de distribuição geográfica de Riencourtia oblongifolia e R. tenuifolia no estado da Bahia.

Riencourtia tenuifolia é reconhecida pela lâmina foliar com margem revoluta e apenas uma nervação evidente, o que a diferencia prontamente de $R$. oblongifolia, que possui margem plana e três nervações evidentes.

\section{Sclerocarpus Jacq.}

Ervas eretas, anuais ou perenes. Folhas alternas, as basais geralmente opostas; lâmina lanceolada ou ovada, inteira ou lobada. Capítulos solitários, radiados; brácteas involucrais em 1 série, elípticas, ovadas, oblanceoladas, espatuladas, lanceoladas ou lineares; receptáculo convexo, com páleas enrijecidas envolvendo completamente o ovário e parte da corola, formando com a cipsela uma estrutura chamada esclerocarpo. Flores do raio neutras; corola do raio verdadeira, amarela ou laranja. Flores do disco bissexuadas; corola tubulosa, amarela ou laranja; anteras enegrecidas ou amarelas; ramos do estilete agudos, pubescentes. Cipselas geralmente obovoides, oblanceoloides, compressas, enegrecidas, lisas ou estriadas, glabras; pápus coroniforme lacerado, de escamas livres diminutas ou cerdas diminutas ou ausente.

Sclerocarpus pode ser reconhecido pelas páleas que envolvem completamente o ovário e parte da corola e, ao amadurecerem, se espessam e enrijecem, desenvolvendo geralmente protuberâncias na superfície (Villaseñor \& Hinojosa-Espinosa 2011). Abrange oito espécies e está distribuído nos Estados Unidos, México, América Central, Venezuela e África (Panero 2007), tendo sido resgistrado para o Brasil apenas recentemente (Alves \& Roque 2016). 
18.1. Sclerocarpus africanus Jacq., Icon. P1. Rar. 1(1): 17, pl. 176. 1871.

Figura 30; Alves \& Roque (2016: figs 2-8).

Arbusto ca. 0,5 m alt.; ramos cilíndricos, estriados, glabrescentes ou setosos. Folhas alternas; pecíolo 0,51 cm compr.; lâmina 4,2-6,8 × 2,4-3,2 cm, cartácea, discolor, elíptica ou ovada, ápice acuminado, margem crenada ou serreada, base atenuada ou decorrente, face adaxial estrigosa, a abaxial setosa. Capítulos terminais, 12,9-13,8 cm compr.; pedúnculo 2,2-13,4 cm compr.; brácteas involucrais 6 ou 7, de dois tipos, $7-10 \times 1-2 \mathrm{~mm}$, espatuladas com ápice similar às folhas, estrigoso, ou 2,8-4,2 × 1-1,4, ovada, estrigosa na face adaxial e setosa na abaxial, ápice acuminado, margem inteira, verdes; páleas 7-9 × 4-5, obovadas, persistentes, rígidas, ápice acuminado, às vezes eroso, margem inteira, estriadas, pubescentes, verdes. Flores ca. 30. Flores do raio ca. 5, ca. $9 \mathrm{~mm}$ compr.; corola ca. $5 \mathrm{~mm}$ compr. (tubo ca. $2 \mathrm{~mm}$ compr.), amareloalaranjada. Flores do disco ca. $9 \mathrm{~mm}$ compr.; corola 4 $5 \mathrm{~mm}$ compr. (tubo ca. $2 \mathrm{~mm}$ compr.), amarela; anteras ca. 1,2 mm compr., enegrecidas, apêndice do conectivo ca. 0,2 $\mathrm{mm}$ compr., lanceolado, ápice acuminado, amarelo, apêndice basal sagitado, filetes amarelos; estilete ca. $4 \mathrm{~mm}$ compr., amarelo, ramos do estilete ca. $2 \mathrm{~mm}$ compr. Cipselas 5-6 $\mathrm{mm}$ compr., oblanceoloides, estipitadas, estriadas, carpopódio assimétrico, alvo; pápus ausente.

Nativa da África (Villaseñor \& Hinojosa-Espinosa 2011). Segundo o Tropicos (2015), a espécie tem registro na China, África do Sul e Estados Unidos; o primeiro registro para Bahia foi feito recentemente por Alves \& Roque (2016). F4: áreas antropizadas. Encontrada com flores e frutos em fevereiro.

Material examinado - Bom Jesus da Lapa, 132'34"S, $43^{\circ} 10^{\prime} 35^{\prime \prime} \mathrm{W}, 521 \mathrm{~m}$ s.n.m., fev. 2000, L.P. Queiroz et al. 5716 (ALCB, HRB, HUEFS)

Sclerocarpus africanus pode ser associada às espécies de Dimerostemma pelo capítulo ser envolvido por brácteas foliáceas similares às folhas. As páleas enrijecidas que envolvem completamente o ovário e parte da corola (vs. páleas membranáceas ou cartáceas, conduplicadas), entretanto, a distingue facilmente daquele gênero.

\section{Simsia Pers.}

Ervas, anuais ou perenes, ou arbustos. Folhas alternas e opostas, ou apenas opostas; lâmina lanceolada, ovada ou subcordada, às vezes deltada, inteira ou 3-5-lobada. Capítulos solitários ou em cimeiras paniculiformes, radiados ou discoides; brácteas involucrais em 2-4 séries; receptáculo convexo, paleáceo. Flores do raio neutras ou ausentes; corola do raio verdadeira, amarelo-limão ou amareloalaranjada. Flores do disco bissexuadas; corola tubulosa, amarelo-limão ou amarelo-alaranjada; anteras amarelas, castanhas ou enegrecidas, apêndice do conectivo estramíneo; ramos do estilete com ápice acuminado, às vezes enrolados. Cipselas obovoides ou elipsoides, obcompressas, com expansões apicais, glabras ou hirsutas, castanhas ou enegrecidas; pápus 2aristado, raramente com 4-12 escamas intermediárias, ou ausente.

O gênero caracteriza-se por possuir brácteas involucrais em 2-4 séries imbricadas, cipselas obcompressas, geralmente sem escamas (Spooner 1990). Simsia possui cerca de 22 espécies, distribuídas no continente americano (Panero 2007). No Brasil, ocorre apenas uma espécie (Nakajima et al. 2015).

\subsection{Simsia dombeyana DC., Prodr. 5: 578. 1836.}

Figuras 30, 31 D-H e 35 C.

Nome popular: ervaço.

Arbusto ca. 1,5 m alt.; ramos cilíndricos, estriados, híspidos. Folhas alternas, às vezes opostas nos ramos mais basais; pecíolo 0,3-2,6 cm compr.; lâmina 5,9$11,3 \times 2,6-7,4 \mathrm{~cm}$, cartácea, discolor, lanceolada ou ovada, ápice acuminado, margem denteada, base truncada ou subcordada, às vezes atenuada, hirsuta em ambas as faces, às vezes mais evidente nas nervações. Capítulos solitários, na axila das folhas ou em cimeiras paniculiformes terminais, $0,8-1,4 \times 0,6-1,2$ $\mathrm{cm}$, radiados; pedúnculo 0,3-8,1 cm compr.; invólucro campanulado, brácteas involucrais subiguais, 15-17, em 3 séries, 5-9 × 1-2 $\mathrm{mm}$, lanceoladas, ápice acuminado, margem inteira, hirsutas, verdes; páleas $8-$ $10 \times 1-2 \mathrm{~mm}$, lanceoladas, conduplicadas, persistentes, ápice acuminado, margem inteira. Flores 31-33. Flores do raio ca. 6, 10-12 $\mathrm{mm}$ compr.; corola 5-6 $\mathrm{mm}$ compr. (tubo ca. 1,5 mm compr., pubescente), amarela. Flor do disco 7-11 mm compr.; corola 5-6 mm compr. (tubo ca. $1 \mathrm{~mm}$ compr., pubescente), amarela; anteras ca. 2,5-3 mm compr., amarelas ou castanhas, apêndice do conectivo ca. $0,2 \mathrm{~mm}$ compr., lanceolado ou triangular, ápice agudo ou obtuso, apêndice basal sagitado, filetes amarelos; estilete 5-6 $\mathrm{mm}$ compr., amarelo, ramos do estilete ca. 0,5-1 $\mathrm{mm}$ compr., pubescentes. Cipselas 4-5 mm compr., obovoides, pubescentes ou glabrescentes, com embrião confinado no centro e borda plana ao redor, cinza ou castanhas com manchas enegrecidas ou creme, carpopódio inconspícuo; pápus com 2 aristas de 2-3 mm compr., pubescentes.

Distribuída na América do Sul (Spooner 1990); no Brasil, ocorre em Minas Gerais e nos estados do Nordeste (Nakajima et al. 2015). B5, B8, C5, C7, C8, D2, D6, E6, F3, F5, F6, G5, G6: caatinga. Encontrada com flores e frutos de janeiro a abril.

Material selecionado - Abaíra, $13^{\circ} 15^{\prime} \mathrm{S}, 41^{\circ} 45^{\prime} \mathrm{W}, 900-1500$ m s.n.m., jan. 1992, D.J.N. Hind et al. H 51403 (HUEFS); Brumado, $14^{\circ} 10^{\prime} \mathrm{S}, 41^{\circ} 29^{\prime} \mathrm{W}$, jan. 2000, A.M. Giulietti \& R.M. Harley 1699 (HUEFS); Caetité, jan. 1983, M.L. Guedes 2767 (ALCB); Campo Formoso, $10^{\circ} 21^{\prime} 58^{\prime \prime} \mathrm{S}, 40^{\circ} 35^{\prime} 47^{\prime \prime} \mathrm{W}$, fev. 2000, A.M. Giulietti \& R.M. Harley 1813 (ALCB, HUEFS); Coribe, $13^{\circ} 41^{\prime} 34^{\prime \prime S}, 44^{\circ} 15^{\prime} 06^{\prime \prime W}, 625 \mathrm{~m}$ s.n.m., abr. 2002, F. França et al.

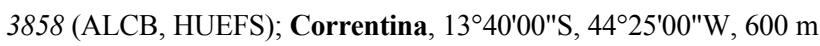
s.n.m., R.M. Harley 21718 (CEPEC); Formosa do Rio Preto, 


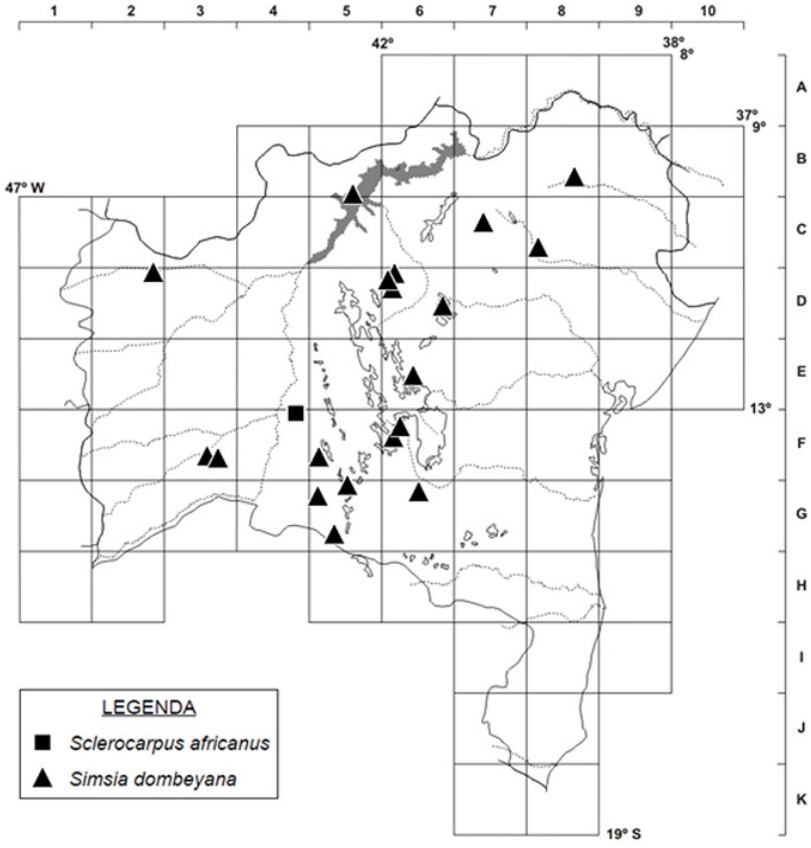

Figura 30. Mapa de distribuição geográfica de Sclerocarpus africanus e Simsia dombeyana no estado da Bahia.

$11^{\circ} 4^{\prime} 33^{\prime \prime S}, 45^{\circ} 9^{\prime} 23^{\prime \prime W}, 525$ m s.n.m., mar. 2000, R.M. Harley et al. 53794 (ALCB, HUEFS); Guanambi, 141'ㄷㅇ"S, 4252'54"W, 540 m s.n.m., abr. 2002, F. França et al. 3784 (ALCB, HUEFS); Irecê, $11^{\circ} 11^{\prime} \mathrm{S}, 41^{\circ} 55^{\prime} \mathrm{W}$, mar. 2002, T.S. Nunes \& J. Costa 899 (ALCB, HUEFS); Jussara, $11^{\circ} 05^{\prime} \mathrm{S}, 41^{\circ} 49^{\prime} \mathrm{W}, 610 \mathrm{~m}$ s.n.m., abr. 1984, H.P. Bautista \& O.A. Salgado 926 (ALCB, HUEFS); Morro do Chapéu, $11^{\circ} 33^{\prime} \mathrm{S}, 41^{\circ} 09^{\prime} \mathrm{W}$, abr. 2004, M.L. Guedes et al. 11024 (ALCB); Palmeiras, $12^{\circ} 31^{\prime} 44^{\prime \prime S}, 41^{\circ} 33^{\prime} 32^{\prime \prime} \mathrm{W}$, mar. 1990, A.M. Carvalho 2963 (CEPEC); Pilão Arcado, 0957'59"S, 42²3'29"W, fev. 2000, N.G. Jesus et al. 859 (ALCB, HUEFS); Riacho de Santana, $13^{\circ} 41^{\prime}$ S, 42 $52^{\prime} \mathrm{W}, 600$ m s.n.m., mar. 1981, S.B. Silva 177 (ALCB); Rio de Contas, $13^{\circ} 24^{\prime} 16^{\prime \prime S}, 41^{\circ} 49^{\prime} 46^{\prime \prime W}, 993$ m s.n.m., fev. 2004, R.M. Harley 54997 (HUEFS); Uauá, 0943'23"S, 39¹9'56"W, mar. 2000, E. Saar et al. 17 (ALCB, HUEFS); Urandi, 14²45'55"S, 42 39'09"W, 709 m, ago. 2009, M.L. Guedes et al. 15744 (ALCB).

Os espécimes herborizados frequentemente não possuem flores do raio ou elas não são evidentes, dando uma falsa impressão de que os capítulos são discoides. As cipselas obcompressas com 2 projeções apicais e pápus 2-aristado, contudo, são características diagnósticas para o reconhecimento da espécie.

\section{Sphagneticola O.Hoffm.}

Ervas perenes, prostradas, estoloníferas. Folhas opostas; lâmina ovada a trulada, trilobada. Capítulos solitários, terminais ou axilares, radiados; brácteas involucrais subiguais, em 2 séries; receptáculo convexo a cônico, paleáceo. Flores do raio femininas; corola do raio verdadeira, amarela ou laranja, com limbo glandular na face abaxial. Flores do disco bissexuadas; corola tubulosa, 5-laciniada, com tricomas híspidos na face adaxial, amarela ou laranja; anteras enegrecidas, apêndice do conectivo com tricomas glandulares; ramos do estilete com ápice acuminado. Cipselas obpiriformes, oblanceoloides, obovoides, compressas ou não, às vezes aladas ou tuberculadas; pápus coroniforme com ápice lacerado ou eroso.

Sphagneticola pode ser reconhecido pelas flores do raio com limbo glandular na face abaxial, lacínias das flores do disco com tricomas híspidos na face adaxial e cipselas geralmente tuberculadas na maturidade (Pruski 1996). O gênero abrange quatro espécies e apresenta distribuição pantropical (Panero 2007). No Brasil, está distribuído em todos os estados, representado por duas espécies (Nakajima et al. 2015). Na Bahia, ocorre uma espécie.

20.1. Sphagneticola trilobata (L.) Pruski, Mem. New York Bot. Gard. 78: 114. 1996. Silphium trilobatum L. Syst. Nat. (ed. 10) 2: 1233. 1759. Wedelia trilobata (L.) Hitchc. Rep. (Annual) Missouri Bot. Gard. 4: 99. 1893.

$=$ Wedelia paludosa DC. Prodr. 5: 538. 1836.

Figuras 32 e 35D; Baker (1884: prancha 59)

Nomes populares: calêndula; bem-me-quer; mal-mequer.

Erva estolonífera ca. 0,3 m alt.; ramos cilíndricos, estriados, glabrescentes ou tomentosos. Folhas sésseis ou curto-pecioladas (pecíolo até $0,5 \mathrm{~cm}$ compr.); lâmina 2,1-9,5 × 0,7-3,9 cm, cartácea, discolor, inteira ou trilobada, estreito-elíptica ou elíptica, ápice agudo ou acuminado, margem serreada, base séssil ou decorrente, setosas em ambas as faces. Capítulos 0,7$1,1 \times 0,7-1,4 \mathrm{~cm}$; pedúnculo 0,3-13,2 cm compr.; invólucro campanulado, brácteas involucrais 10-14, 7$10 \times 3-4 \mathrm{~mm}$, estreito-elípticas ou elípticas, ápice agudo ou acuminado, margem inteira, verdes, setosas; receptáculo convexo, páleas 6-9 × 1-2 $\mathrm{mm}$, lanceoladas ou ovadas, conduplicadas, persistentes, ápice acuminado, ciliado, sinuoso, margem inteira. Flores 61-75. Flores do raio 14-18, 11-14 mm compr.; corola 8-11 mm compr. (tubo ca. $1 \mathrm{~mm}$ compr.), amarela. Flores do disco 6-9 $\mathrm{mm}$ compr.; corola 4-6 $\mathrm{mm}$ compr. (tubo 0,5-2 $\mathrm{mm}$ compr.), amarela; anteras ca. 2,1 $\mathrm{mm}$ compr., apêndice do conectivo ca. 0,25 mm compr., triangular, ápice obtuso ou agudo, apêndice basal sagitado, filetes amarelos; estilete $6 \mathrm{~mm}$ compr., amarelo, ramos do estilete ca. $1,5 \mathrm{~mm}$ compr., pubescentes. Cipselas 3-4 $\mathrm{mm}$ compr., oblanceoloides ou obovoides, estipitadas ou levemente estipitadas, glabrescentes, às vezes glandulosas ou tuberculadas no ápice quando maduras, castanhas ou enegrecidas, carpopódio inconspícuo; pápus coroniforme ca. $1 \mathrm{~mm}$ compr., ápice fimbriado.

Sphagneticola trilobata está distribuída do México à Argentina, e amplamente cultivada como ornamental, naturalizando-se na Austrália, Malásia, Ilhas do Pacífico e Estados Unidos (Pruski 1996). No Brasil, ocorre em todos os estados (Nakajima et al. 2015). C7, D6, D7, D9, D10, E6, E7, E8, E9, E10, F8, G7, G8, H8, I8: áreas antropizadas. Encontrada com flores e frutos durante todo o ano. 

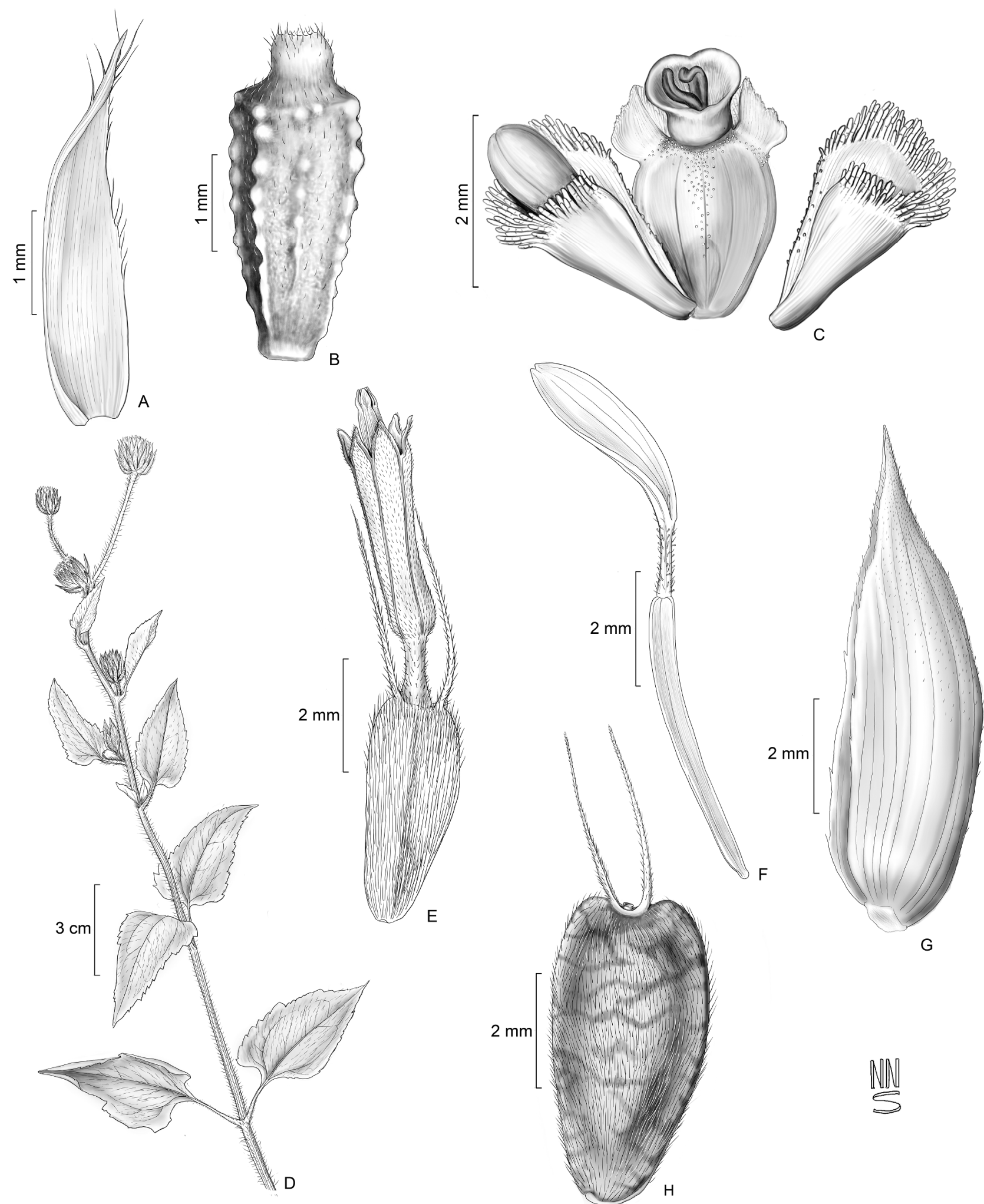

Figura 31. A, B. Eleutheranthera ruderalis: A- pálea; B- cipsela. C. Parthenium hysterophorus: cipsela associada a duas páleas e uma flor do disco. D-H. Simsia dombeyana: D- ramo; E- flor do disco; F- flor do raio; G- pálea; H- cipsela com embrião confinado no centro e borda plana. (A, B- Guedes 2; C- Peso 2 ; D-H- Guedes 2767).

Material selecionado - Alagoinhas, $12^{\circ} 10^{\prime} \mathrm{S}, 38^{\circ} 24^{\prime} \mathrm{W}$, abr. 2002, N.C.R. Santos et al. 20 (ALCB, HUEFS); Andaraí, dez. 2012, T.L. Vieira 125 (ALCB); Barro Preto, 1447'28,2"S, 39³0'25,8"W, 163 m s.n.m., dez. 2013, M. Alves et al. 291 (ALCB, HUEFS); Boa Nova, 14²3'42,8'S, 40¹0'31,5"W, $780 \mathrm{~m}$ s.n.m., jul. 2013, M. Alves et al. 249 (ALCB, HUEFS); Boa Vista do Tupim, abr. 2001, L.J. Alves et al. 167 (ALCB); Buerarema, 14 ${ }^{\circ} 57^{\prime} \mathrm{S}, 39^{\circ} 17^{\prime} \mathrm{W}$, maio 2007, G.S. Campos \& A.P. Alencar 17 (ALCB); Cairu, $22^{\circ} 00^{\prime} \mathrm{S}, 38^{\circ} 54^{\prime} \mathrm{W}$, out. 1996, M.L. Guedes \& M. Acioly 4791 (ALCB); Camaçari, nov. 1998, A.G. Matos \& K. Ribeiro s.n. (HUEFS 38991); Conceição do Almeida, maio 2013, W.C. Andrade \& C.I.S. Lucas 84 (HUEFS); Conde, abr. 1996, 
E.M. Costa-Neto 10 (HUEFS); Cruz das Almas, nov. 2013, N.X.M. Sousa 5 (ALCB); Dom Macedo Costa, $12^{\circ} 56^{\prime} \mathrm{S}, 39^{\circ} 10^{\prime} \mathrm{W}$, jul. 1985, L.R. Noblick \& Lemos 3997 (HUEFS); Entre Rios, jan. 2011, M. Alves \& P.B. Alves 13 (ALCB); Eunápolis, 1447'51"S, 3902'13"W, nov. 2014, M. Alves et al. 370 (ALCB); Feira de Santana, $12^{\circ} 15^{\prime} \mathrm{S}, 38^{\circ} 58^{\prime} \mathrm{W}, 1983$, Discentes da UEFS s.n. (HUEFS 3627); Iaçu, nov. 2001, E.C. Oliveira 1 (HUEFS); Ibirapitanga, abr. 2013, A.O. Matos 38 (HUEFS); Igrapiúna, 135ㄴ'36"S, 39²18'38"W, 298 m s.n.m., jul. 2010, M.L. Guedes et al. 17500 (ALCB); Ilhéus, $15^{\circ} 04^{\prime} 02^{\prime \prime S}, 39^{\circ} 00^{\prime} 10^{\prime \prime} \mathrm{W}, 15$ m s.n.m., dez. 2013, M. Alves 289 (ALCB, HUEFS); Itacaré, 14²18'S, $38^{\circ} 58^{\prime} \mathrm{W}$, mar. 1974, R.M. Harley et al. 17554 (CEPEC); Ituberá, fev. 2006, Equipe Ecopol s.n. (ALCB 92961); Jacobina, $11^{\circ} 10^{\prime} 11^{\prime \prime S}, 40^{\circ} 30^{\prime} 23^{\prime \prime} \mathrm{W}, 491 \mathrm{~m}$ s.n.m., jun. 2011, M. Alves et al. 28 (ALCB); Lamarão do Passé, $12^{\circ} 34^{\prime} 52^{\prime \prime} \mathrm{S}, 38^{\circ} 22^{\prime} 49^{\prime \prime} \mathrm{W}$, jan. 1994 M.L. Guedes \& C. Bastos 3255 (ALCB); Lençóis, $12^{\circ} 40^{\prime} 17^{\prime \prime S}, 41^{\circ} 19^{\prime} 38^{\prime \prime W}, 320-360$ m s.n.m., dez. 2002, F. França et al. 3902 (ALCB, HUEFS); Maraú, out. 1989, M.Z. Almeida 9 (ALCB); Miguel Calmon, $11^{\circ} 21^{\prime} 33^{\prime \prime} \mathrm{S}, 40^{\circ} 33^{\prime} 52^{\prime \prime} \mathrm{W}, 620 \mathrm{~m}$ s.n.m., abr. 2001, N.G. Jesus et al. 1291 (ALCB, HUEFS); Morro do Chapéu, jul. 2013, L.V. Vasconcelos et al. 551 (HUEFS); Mucugê, $12^{\circ} 58^{\prime} 24^{\prime \prime S}, 41^{\circ} 20^{\prime} 28^{\prime \prime W}, 1025$ m s.n.m., out. 2014, $N$. Roque et al. 4508 (ALCB); Muritiba, maio 2010, L.C. Silva 341 (ALCB); Nova Canaã, jun. 2012, A.S. Santos 8 (HUEFS); Nova Itarana, jul. 1982, K.B. Britto s.n. (ALCB 16269); Pindobaçu, $10^{\circ} 39^{\prime} 45^{\prime \prime S}, 40^{\circ} 20^{\prime} 28^{\prime \prime} \mathrm{W}$, dez. 2008, L.A. Sousa 195 (HUEFS); Porto Seguro, $16^{\circ} 26^{\prime} 58^{\prime \prime} \mathrm{S}, 39^{\circ} 03^{\prime} 53^{\prime \prime W}$, dez. 1992, V.C. Souza \& C.M. Sakuragui 2125 (UEC); Salvador, maio 2013, M. Alves \& A. Stadnik 142 (ALCB, HUEFS); Santo Amaro, mar. 2013, E.M.G.B. Silva 152 (HUEFS); São Francisco do Conde, ago. 2011, M.S. Lisboa et al. 237 (ALCB); São Sebastião do Passé, mar. 2001, D.L. Santana 133 (ALCB); Una, dez. 1987, E.B. Santos \& M.C. Alves 177 (HUEFS); Uruçuca, 14²0'25"S, 39²'3"W, 60-500 m s.n.m., mar. 2010, L.A. Mattos-Silva et al. 5181 (HUEFS); Varzedo, 1257'39"S, 39²6'47"W, fev. 2015, M.L. Guedes 23259 (ALCB).

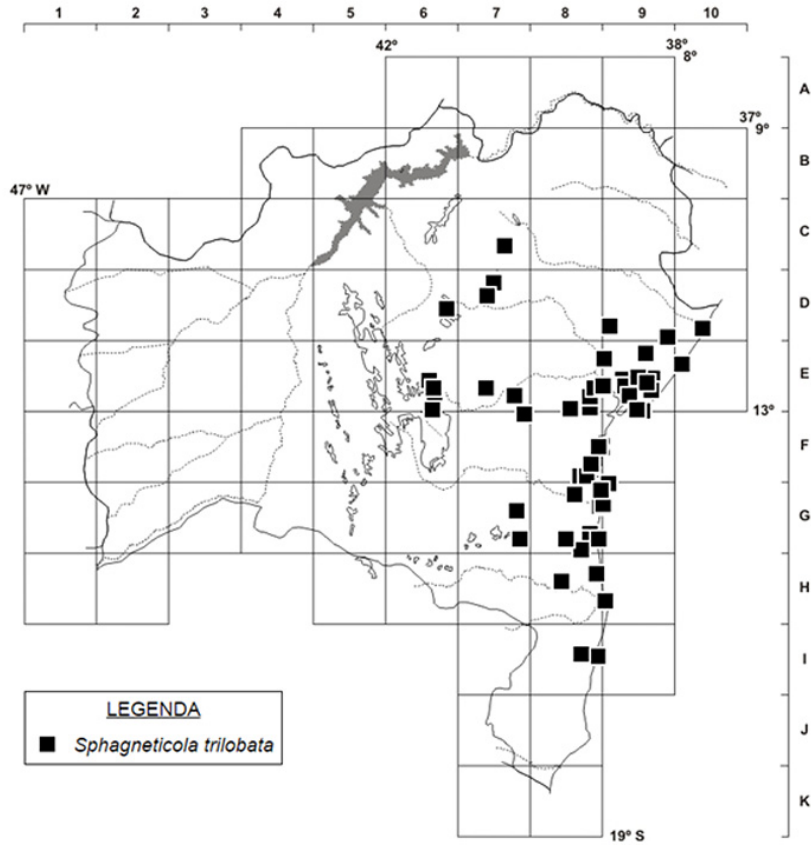

Figura 32. Mapa de distribuição geográfica de Sphagneticola trilobata no estado da Bahia.
Sphagneticola trilobata apresenta grande plasticidade fenotípica, sendo encontrada na Bahia tanto como ornamental quanto em áreas abertas e beiras de estradas. Nos herbários, é comumente encontrada no gênero Wedelia, do qual se distingue principalmente por ser uma erva estolonífera (vs. ervas ou arbustos prostrados ou eretos) e possuir corola tubulosa com lacínias adaxialmente híspidas (vs. geralmente glabras).

\section{Synedrella Gaertn.}

Ervas eretas ou arbustos. Folhas opostas; lâmina ovada ou elíptica. Capítulos em cimeiras simples, axilares ou terminais, radiados; brácteas involucrais subiguais, 4, em 2 séries, foliáceas; receptáculo plano, paleáceo. Flores do raio femininas; corola do raio verdadeira, amarela. Flores do disco bissexuadas; corola tubulosa, amarela; anteras enegrecidas, apêndice do conectivo com ápice agudo, apêndice basal sagitado; ramos do estilete com ápice agudo. Cipselas dimórficas, as do raio oblanceoloides, obcompressas, enegrecidas, aladas, alas profundamente laceradas, estramíneas; cipselas do disco obcuneadas, obcompressas, enegrecidas, lisas ou tuberculadas; pápus 2-aristado, nas flores do raio as aristas fundidas às alas, nas flores do disco bem evidentes.

Synedrella pode ser reconhecido por possuir 4 brácteas involucrais foliáceas, capítulos radiados, receptáculo paleáceo e cipselas dimórficas, sendo as das flores do raio com alas laceradas de ápice acuminado (Panero 2007). O gênero é monoespecífico e possui distribuição pantropical, sendo originalmente neotropical (Turner 1994).

21.1. Synedrella nodiflora (L.) Gaertn., Fruct. Sem. P1. 2(3): 456; t. 171, f. 7. 1791. Verbesina nodiflora L., Cent. P1. I: 28. 1755.

Figuras 33, 35E e 38A-D.

Erva ou arbusto $0,3-1 \mathrm{~m}$ alt.; ramos cilíndricos, estriados, setulosos. Folhas com pecíolo 0,3-2 mm compr.; lâmina 4,9-11,7 × 1,9-5,8 cm, membranácea, discolor, estreito-elíptica ou elíptica, ápice acuminado, margem serreada, base decorrente, setulosa em ambas as faces. Capítulos sésseis ou curto-pedunculados (pedúnculo ca. $1 \mathrm{~mm}$ compr., raramente até $3,5 \mathrm{~cm}$ compr.), $0,8-0,9 \times 0,5-0,7 \mathrm{~cm}$, radiados; invólucro campanulado, brácteas involucrais $8-9 \times 2-3 \mathrm{~mm}$, lanceoladas, ápice acuminado, margem inteira, verdes, pubescentes; páleas $6-8 \times 0,5-1,5 \mathrm{~mm}$, lineares ou estreito-elípticas, planas ou levemente conduplicadas, persistentes, ápice agudo ou obtuso, ciliado, margem inteira. Flores 15-23. Flores do raio 5-8, ca. $8 \mathrm{~mm}$ compr.; corola 4-5 mm compr. (tubo ca. $2 \mathrm{~mm}$ compr., glabrescente). Flores do disco 5,5-7 $\mathrm{mm}$ compr.; corola 3-4 $\mathrm{mm}$ compr. (tubo 1,5-2 $\mathrm{mm}$ compr., glabro); anteras ca. $1 \mathrm{~mm}$ compr., apêndice do conectivo ca. 0,1 $\mathrm{mm}$ compr., triangular, enegrecido, filetes amarelos; estilete ca. $3 \mathrm{~mm}$ compr., amarelo, 
ramos do estilete ca. $1 \mathrm{~mm}$ compr., ápice pubescente. Cipselas do raio 3-4 mm compr., lisas e glabras, alas ca. $1 \mathrm{~mm}$ larg., pubescentes, carpopódio assimétrico; pápus com aristas de 1-2 mm compr. fundidas às alas, pubescentes. Cipselas do disco 3-4 mm compr., castanhas, lisas ou tuberculadas, carpopódio cilíndrico; pápus com aristas de 3-4 mm compr., pubescentes.

Amplamente distribuída, no Brasil, ocorre em todas as Regiões (Nakajima et al. 2015). D7, E6, E8, E9, F8, G8, I8, K8: áreas antropizadas. Encontrada com flores e frutos durante todo o ano.

Material selecionado - Cachoeira, $12^{\circ} 32^{\prime} \mathrm{S}, 39^{\circ} 05^{\prime} \mathrm{W}, 40-120$ m s.n.m., ago-set. 1980, Grupo Pedra do Cavalo 632 (ALCB, HUEFS); Conceição do Almeida, jun. 1975, Y.B. Azevedo s.n. (ALCB 21372); Eunápolis, $16^{\circ} 22^{\prime} \mathrm{S}, 39^{\circ} 34^{\prime} \mathrm{W}$, fev. 2003, B.A.

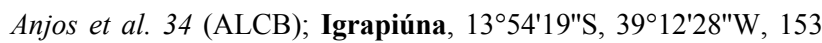
m s.n.m., jul. 2010, M.L. Guedes et al. 17229 (ALCB); Jacobina, $11^{\circ} 14^{\prime} \mathrm{S}, 40^{\circ} 30^{\prime} \mathrm{W}$, jul. 1996, D.J.N. Hind et al. PCD 3376 (ALCB, HUEFS); Ilhéus, jun. 1988, T.S. Santos 4366 (ALCB); Lençóis, $12^{\circ} 34^{\prime} \mathrm{S}, 41^{\circ} 34^{\prime} \mathrm{W}$, mar. 1984, L.R. Noblick 3001 (HUEFS); Nilo Peçanha, 134ㄴ' $41^{\prime \prime S}, 39^{\circ} 02^{\prime} 43^{\prime \prime W}$, jul. 2010, M.L. Guedes 17588 (ALCB); Porto Seguro, maio 1974, R.M. Harley et al. 17266 (CEPEC); Salvador, nov. 2010, M. Alves 6 (ALCB); Sapeaçu, $12^{\circ} 44^{\prime} 36^{\prime \prime S}, 39^{\circ} 13^{\prime} 03^{\prime \prime W}, 221$ m s.n.m., ago. 2015, L.Y.S. Aona et al. 4114 (ALCB); São Francisco do Conde, maio 1991, F.P. Bandeira \& M.L. Guedes s.n. (ALCB 23512); Simões Filho, 1246'27"S, $38^{\circ} 26^{\prime} 45^{\prime \prime} \mathrm{W}$, maio 2002, D.M. Loureiro et al. 622 (ALCB); Vera Cruz, $12^{\circ} 59^{\prime} \mathrm{S}, 38^{\circ} 42^{\prime} \mathrm{W}$, fev. 2002, M.V. Moraes 493 (HUEFS).

Synedrella nodiflora é comumente identificada no gênero Calyptocarpus, do qual se distingue por possuir as cipselas dimórficas, as do raio com alas laceradas (vs. cipselas isomórficas sem alas).

\section{Synedrellopsis Hieron. \& Kuntze ex Kuntze}

Ervas prostradas ou decumbentes, anuais ou perenes. Folhas opostas; lâmina lanceolada, ovada ou trulada. Capítulos solitários, axilares, disciformes; brácteas involucrais subiguais, 2; receptáculo plano, epaleáceo. Flores femininas 2; corola tubulosofiliforme, 3-laciniada, alva. Flores bissexuadas 2; corola tubulosa, 4-laciniada, alva; anteras enegrecidas. ramos do estilete com ápice obtuso. Cipselas dimórficas, as das flores femininas oblanceoloides, plano-convexas, as das flores bissexuadas obovoides, obcompressas, com alas profundamente laceradas, estramíneas; pápus 2-aristado ou ausente.

Synedrellopsis é reconhecido pelos capítulos com 2 brácteas involucrais foliáceas, 4 flores ( 2 femininas e 2 bissexuadas) e receptáculo epaleáceo, além de algumas das cipselas apresentarem alas laceradas de ápice arredondado (Panero 2007). O gênero é monoespecífico e ocorre na Argentina, Bolívia, Brasil e Paraguai (Panero 2007).

\subsection{Synedrellopsis grisebachii Hieron. \& Kuntze,} Revis. Gen. Pl. 3(3): 180. 1898.

\section{Figuras 33 e $38 \mathrm{E}-\mathrm{G}$.}

Erva prostrada; ramos cilíndricos ou compressos, setosos. Folhas com pecíolo 0,2-0,8 cm compr.; lâmina
0,9-2,3 × 0,6-1,7 cm, cartácea, discolor, lanceolada ou amplamente ovada, ápice agudo ou acuminado, margem serreada, base atenuada ou decorrente, setulosa em ambas as faces. Capítulos sésseis ou curtopedunculados (pedúnculo ca. 0,2 cm compr.), 0,4-0,6 $\times$ $0,2-0,3 \mathrm{~cm}$; invólucro cilíndrico, brácteas $4-6 \times 2-2,5$ mm compr., lanceoladas ou ovadas, ápice mucronado, margem inteira, verdes, setosas. Flores femininas ca. 3,5 $\mathrm{mm}$ compr.; corola ca. $2 \mathrm{~mm}$ compr. Flores bissexuadas 2,5-3,1 mm compr.; corola 1,5-2 mm compr. (tubo 0,20,5 mm compr., glabro); anteras ca. $1 \mathrm{~mm}$ compr., apêndice do conectivo ca. 0,2 $\mathrm{mm}$ compr., triangular, ápice acuminado, apêndice basal cordiforme, filetes alvos; estilete ca. 1,2 mm compr., alvo, ramos do estilete ca. 0,1-0,5 mm compr. Cipselas das flores femininas ca. $3 \mathrm{~mm}$ compr., pubescentes no ápice; pápus ausente. Cipselas das flores bissexuadas ca. $4 \mathrm{~mm}$ compr., enegrecidas, alas ca. $1 \mathrm{~mm}$ larg., carpopódio assimétrico, circular, com elevações estramíneas no centro; pápus com 2 aristas de 0,2-0,5 mm compr.

Encontra-se naturalizada em Goiás (Nakajima et al. 2015), sendo aqui seu primeiro registro para o estado da Bahia. D6, D7, I8: áreas antropizadas. Encontrada com flores e frutos em julho.

Material examinado - Eunápolis, $16^{\circ} 22^{\prime} 00^{\prime \prime} \mathrm{S}, 39^{\circ} 50^{\prime} 24^{\prime \prime} \mathrm{W}$, jul. 2006, M.L. Guedes et al. 7545 (ALCB); Morro do Chapéu, $11^{\circ} 37$ 'S, $40^{\circ} 59 " \mathrm{~W}$, out. 2007, L.P. Queiroz et al. 13219 (HUEFS).

A literatura refere um único tipo de cipsela para Synedrellopsis; contudo, foram observadas cipselas dimórficas nos espécimes analisados. Apesar de $S$. grisebachii possuir algumas das cipselas com alas laceradas, ela se diferencia de Synedrella nodiflora pelos capítulos disciformes (vs. radiados), as 2 brácteas involucrais (vs. 4), receptáculo epaleáceo (vs. paleáceo) e alas das cipselas com ápice arredondado (vs. acuminado).

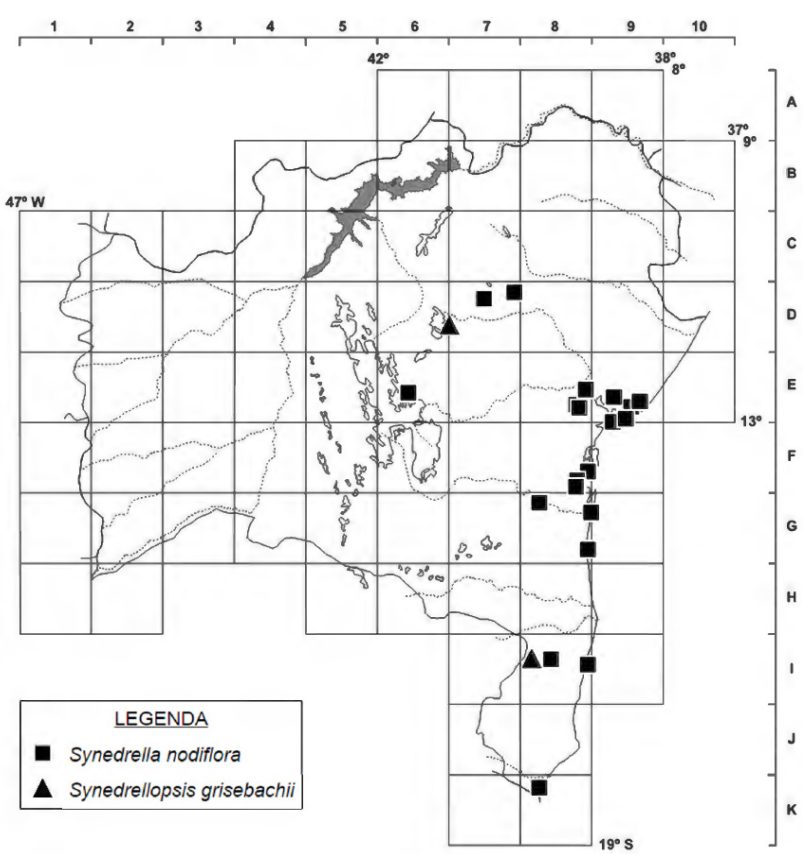

Figura 33. Mapa de distribuição geográfica de Synedrella nodiflora e Synedrellopsis grisebachii no estado da Bahia. 


\section{Tilesia G.Mey.}

Ervas perenes ou arbustos escandentes. Folhas opostas; lâmina lanceolada ou ovada. Capítulos em dicásios ou em cimeiras simples ou paniculiformes, terminais, discoides ou radiados; brácteas involucrais em 2 ou 3 séries; receptáculo plano ou convexo, paleáceo. Flores do raio neutras, femininas e estéreis ou ausentes; corola do raio verdadeira, amarela ou alaranjada. Flores bissexuadas com corola tubulosa, amarela ou raramente vermelha; anteras enegrecidas, apêndice do conectivo ovado, com tricomas glandulares; ramos do estilete com ápice agudo. Cipselas obpiriformes, obovoides ou oblanceoloides, compressas, carnosas quando maduras (bacáceas), exocarpo castanho quando seco; pápus coroniforme diminuto ou ausente.

Tilesia é reconhecido por possuir cipselas obpiriformes ou obovoides, carnosas na maturidade, com exocarpo castanho quando secas e pápus coroniforme diminuto ou ausente (Panero 2007). O gênero possui três espécies, distribuídas nas florestas úmidas tropicais das Américas (Panero 2007). Apenas uma espécie ocorre no Brasil, com distribuição em todos os estados (Nakajima et al. 2015).

23.1. Tilesia baccata (L.) Pruski, Novon 6(4): 414. 1996. Coreopsis baccata L., Pl. Surin.: 14. 1775. Wulffia baccata (L.) Kuntze, Revis. Gen. Pl. 1: 373. 1891.

= Wulffia maculata (Ker Gawl.) DC., Prodr. 5: 563. 1836.

$=$ Wulffia scandens DC., Prodr. 5: 564. 1836.

= Wulffia stenoglossa (Cass.) DC. Prodr. 5: 563. 1836.

Figuras 34 e 35F; Baker (1884: prancha 57).

Arbusto escandente, às vezes com ramos decumbentes, ca. 1-4 m alt.; ramos cilíndricos, estriados, híspidos, setosos ou estrigosos, às vezes com manchas vináceas. Folhas com pecíolo $0,2-3 \mathrm{~cm}$ compr.; lâmina $5,5-11,7 \times 1,5-9,1 \mathrm{~cm}$, membranácea ou subcoriácea, discolor, lanceolada ou ovada, ápice agudo, acuminado ou caudado, margem serreada, base atenuada, raramente arredondada, setosa em ambas as faces, às vezes bulada. Capitulescências em dicásios; pedúnculo 0,7-3,1 cm compr. Capítulo $(0,5) 1-1,5 \times$ $(0,5) 1,2-1,7 \mathrm{~cm}$, radiado; invólucro amplamente campanulado ou subgloboso, brácteas involucrais subiguais 15-17, em 2 séries, 4-7 $\times 1-2 \mathrm{~mm}$, lanceoladas, ápice agudo ou acuminado, às vezes com a parte apical reflexa, margem inteira, verdes; receptáculo plano ou levemente convexo, páleas 5-7 $\times$ 2-3 mm compr., ovadas ou lanceoladas, naviculares, conduplicadas, persistentes, carenadas, ápice cuspidado, margem inteira, pubescentes. Flores 78110. Flores do raio 7-13, 7,5-14 mm compr., neutras ou femininas e estéreis; corola 6,5-12 $\mathrm{mm}$ compr. (tubo 1-1,5 mm compr., glabrescente), amarela. Flores do disco 7-8 $\mathrm{mm}$ compr.; corola $4-5,5 \mathrm{~mm}$ compr. (tubo ca. $1 \mathrm{~mm}$ compr.), lacínias pubescentes, amarela; anteras ca. 2,5 $\mathrm{mm}$ compr., apêndice do conectivo ca. $0,3 \mathrm{~mm}$ compr., amarelo, ápice agudo, apêndice basal sagitado, filetes amarelos; estilete ca. $5 \mathrm{~mm}$ compr., amarelo, ramos do estilete ca. $2 \mathrm{~mm}$ compr., pubescentes. Cipselas 3-4 mm compr., oblanceoloides ou obovoides, glabras, verdes, castanhas ou enegrecidas quando secas, carpopódio inconspícuo; pápus ausente.

Registrada para o Equador, Peru, Brasil e, possivelmente, Colômbia (Pruski 1996). B9, C7, C9, D6, D7, D9, D10, E2, E3, E5, E8, E9, E10, F6, F7, F8, G3, G5, G7, G8, I8, J8, K8: áreas antropizadas e bordas de matas. Encontrada com flores e frutos durante todo o ano.

Material selecionado - Abaíra, $13^{\circ} 18^{\prime} \mathrm{S}, 41^{\circ} 48^{\prime} \mathrm{W}, 1000 \mathrm{~m}$ s.n.m., dez. 1992, W. Ganev 1753 (HUEFS); Alagoinhas, $12^{\circ} 08^{\prime} 00^{\prime \prime} \mathrm{S}, 38^{\circ} 26^{\prime} 08^{\prime \prime} \mathrm{W}$, maio 2001, L.E. Figueroa et al. 128 (ALCB, HUEFS); Barreiras, $12^{\circ} 09^{\prime} 10^{\prime \prime} \mathrm{S}, 44^{\circ} 59^{\prime} 24^{\prime \prime} \mathrm{W}, 500 \mathrm{~m}$ s.n.m., mar. 1971, H.S. Irwin et al. 31309 (SP); Boa Nova, $14^{\circ} 23^{\prime} 43^{\prime \prime S}, 40^{\circ} 10^{\prime} 32 " \mathrm{~W}, 780 \mathrm{~m}$ s.n.m., jul. 2013, M. Alves et al. 248 (ALCB, HUEFS); Camaçari, out. 1995, M.L. Guedes et al. s.n. (ALCB 27553); Conde, $11^{\circ} 52^{\prime} \mathrm{S}, 37^{\circ} 35^{\prime} \mathrm{W}$, nov. 2011, E.N. Matos \& G. Vidal 838 (ALCB, HUEFS); Cruz das Almas, set. 1974, G.C.P. Pinto 42410 (ALCB); Elísio Medrado, jul. 2015, A. Gandara 110 (ALCB); Entre Rios, set. 2010, M. Alves et al. 1 (ALCB); Esplanada, $12^{\circ} 08^{\prime} 14^{\prime \prime S}, 37^{\circ} 50^{\prime} 32^{\prime \prime} \mathrm{S}$, maio 2005 , L. Freire \& M.L. Guedes 55 (ALCB); Eunápolis, $16^{\circ} 22^{\prime} \mathrm{S}, 39^{\circ} 34^{\prime} 00^{\prime \prime} \mathrm{W}, 200$ m s.n.m., jan. 1997, M.L. Guedes et al. 4253 (ALCB); Feira de Santana, $12^{\circ} 11^{\prime} \mathrm{S}, 38^{\circ} 58^{\prime} \mathrm{W}, 230 \mathrm{~m}$ s.n.m., jul. 2005, E. Melo et al. 3967 (HUEFS); Formosa do Rio Preto, $11^{\circ} 58^{\prime} \mathrm{S}, 4^{\circ} 57^{\prime} \mathrm{S}$, fev. 2005, A.B. Xavier \& M.L. Guedes 353 (ALCB); Igrapiúna, $13^{\circ} 48^{\prime} 47,98^{\prime \prime S}, 39^{\circ} 12^{\prime} 15,17^{\prime \prime W}$, abr. 2013, L.Y.S. Aona et al. 2600 (HUEFS); Itacaré, 100 m s.n.m., abr. 1980, T.S. Santos et al. 3548 (HUEFS); Itanagra, $12^{\circ} 22^{\prime} 28^{\prime \prime} \mathrm{S}, 37^{\circ} 58^{\prime} 46^{\prime \prime} \mathrm{W}, 68 \mathrm{~m}$ s.n.m., out. 2008, A.R. Prates et al. 138 (ALCB); Itaparica, maio 1986, M.C. Peso 40 (ALCB); Itiruçu, ago. 1975, P. Souza s.n. (ALCB 19451);

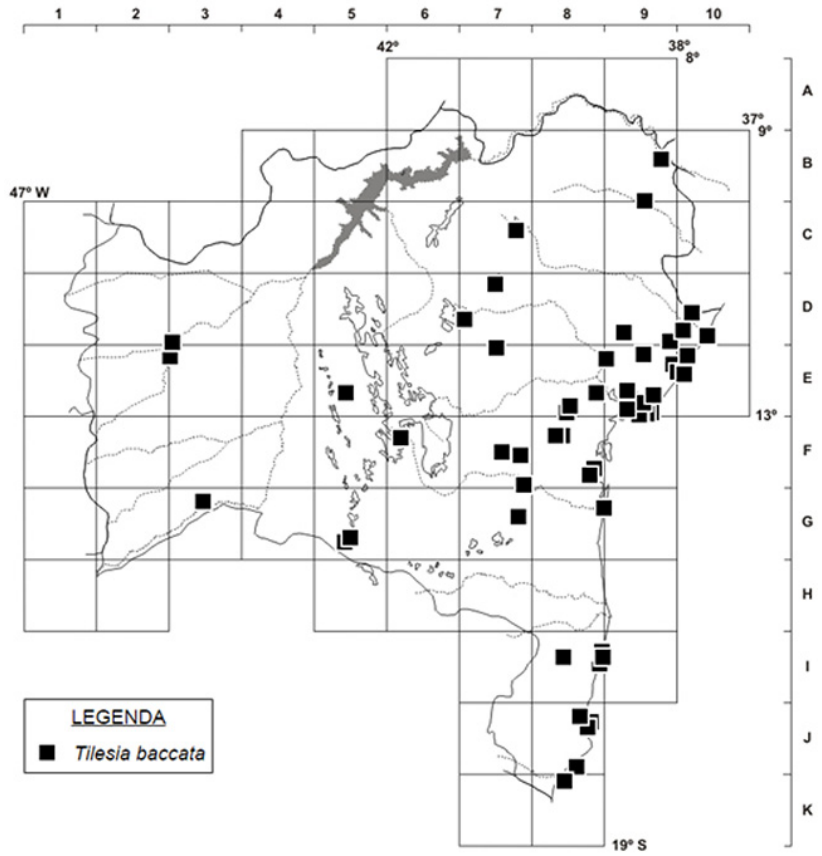

Figura 34. Mapa de distribuição geográfica de Tilesia baccata no estado da Bahia. 

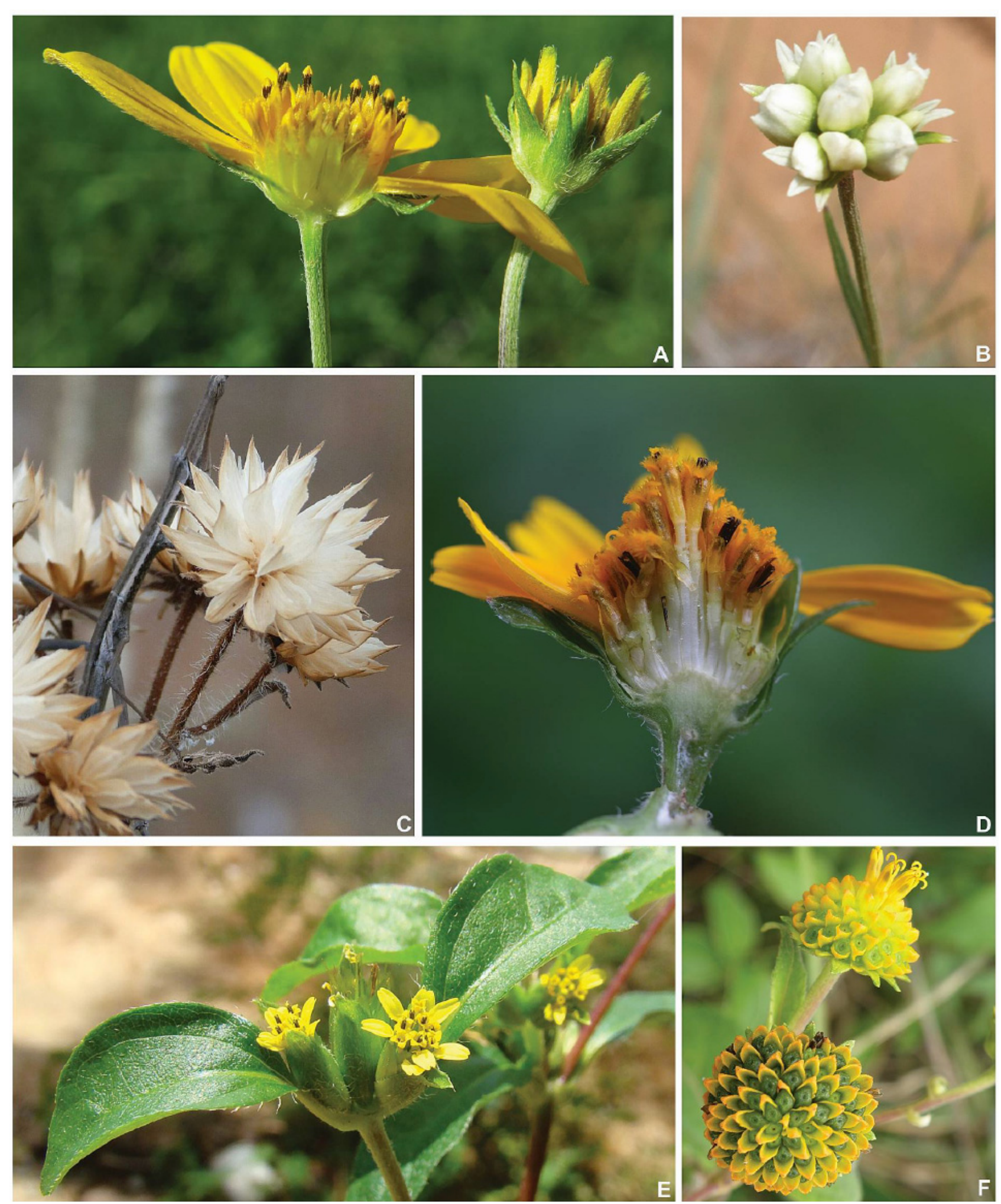

Figura 35. A. Melanthera latifolia: capítulo em corte longitudinal evidenciando as páleas com ápice setoso. B. Riencourtia tenuifolia: capítulos em glomérulo terminal. C. Simsia dombeyana: receptáculo com páleas persistentes com ápice acuminado. D. Sphagneticola trilobata: capítulo em corte transversal. E. Synedrella nodiflora: capítulos terminais. F. Tilesia baccata: capítulos com páleas naviculares persistentes e ápice cuspidado, amarelas e com cipselas verdes. (Fotos: A, D, E- Moura; B, F- Ogasawara; C- Gandara).

Ituberá, $13^{\circ} 43^{\prime} \mathrm{S}, 3^{\circ} 08^{\prime} \mathrm{W}$, jun. 2006, M. Ramalho et al. s.n. (ALCB 75158); Jacobina, jan. 2012, L. Moura et al. 175 (ALCB); Jandaíra, $11^{\circ} 33^{\prime} \mathrm{S}, 37^{\circ} 47^{\prime} \mathrm{W}$, jul. 2013, M.L. Guedes et al. 20979 (ALCB); Jaguaquara, 12³9'39"S, 42³3'44"W, 785 m s.n.m., fev. 1999, F. França et al. 2615 (HUEFS); Jequié, $13^{\circ} 56^{\prime} 60^{\prime \prime S} 40^{\circ} 6^{\prime} 27^{\prime \prime W}, 447$ m s.n.m., abr. 2004, M.N.S. Stapf et al. 304 (HUEFS); Jiquiriçá, s.d., A.J. Ribeiro 442 (ALCB); Jeremoabo, $09^{\circ} 58^{\prime} 60^{\prime \prime} \mathrm{S}, 38^{\circ} 26^{\prime} 16^{\prime \prime} \mathrm{W}, 488$ m s.n.m., out. 2009, $E$. 
Melo et al. 6631 (ALCB, HUEFS); Licínio de Almeida, $14^{\circ} 45^{\prime} 02^{\prime \prime S}, 42^{\circ} 34^{\prime} 09^{\prime \prime W}, 907$ m s.n.m., fev. 2012, M. Alves et al. 74 (ALCB); Maracás, 1329'11"S, 40²4'55"W, 1015 m s.n.m., abr. 2002, K.R.B. Leite et al. 200 (ALCB, HUEFS); Morro do Chapéu,

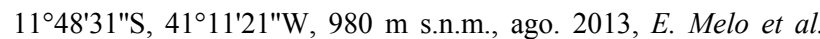
12117 (HUEFS); Mucuri, set. 1978, S. Mori 10531 (CEPEC); Mundo Novo, $12^{\circ} 02^{\prime} 00^{\prime \prime S}, 40^{\circ} 29^{\prime} 00^{\prime \prime W}, 604$ m s.n.m., maio 2006, P.A. Melo 20 (HUEFS); Paulo Afonso, jun. 1982, M.L. Guedes \& L. Paganucci 443 (ALCB); Porto Seguro, 16² $24^{\prime} 53^{\prime \prime S}, 39^{\circ} 17^{\prime} 30^{\prime \prime} \mathrm{W}$, 115 m s.n.m., nov. 2014, M. Alves et al. 373 (ALCB); Prado, $17^{\circ} 11^{\prime} \mathrm{S}, 39^{\circ} 20^{\prime} \mathrm{W}, 70 \mathrm{~m}$ s.n.m., nov. 2009, F.B. Matos et al. 1924 (ALCB); Santa Cruz Cabrália, $16^{\circ} 16^{\prime} \mathrm{S}, 39^{\circ} 01^{\prime} \mathrm{W}$, nov. 2000, M.L. Guedes et al. 7630 (ALCB); Santa Teresinha, 12 ${ }^{\circ} 51^{\prime} 13^{\prime \prime S}$, 39²8'33"W, 750 m s.n.m., fev. 2000, J.G. Jardim et al. 2821 (ALCB, HUEFS); São Francisco do Conde, maio 1991 F.P. Bandeira \& M.L. Guedes s.n. (ALCB 23525); Senhor do Bonfim, $10^{\circ} 24^{\prime} 10^{\prime \prime S}, 40^{\circ} 12^{\prime} 36^{\prime \prime W}, 650$ m s.n.m., jul. 2005, D. Cardoso et al. 646 (HUEFS); Simões Filho, 1248'02"S, 38²7'10"S, jun. 2005 M.L. Guedes \& M. Accioly 11481 (ALCB); Salvador, maio 2012, M. Alves \& L. Moura 101 (ALCB); Ubaíra, abr. 2012, S.F. Conceição et al. 979 (ALCB).

Tilesia baccata apresenta grande plasticidade fenotípica, principalmente em relação às folhas, que variam de subcoriáceas, em ambientes de cerrados mais secos, a cartáceas, em áreas de florestas mais úmidas. Pode ser reconhecida por possuir páleas naviculares, rígidas, com ápice cuspidado e cipselas oblanceoloides ou obovoides, glabras e sem pápus.

\section{Tithonia Desf. ex Juss.}

Ervas eretas, anuais ou perenes, arbustos, raramente árvores. Folhas alternas, às vezes as mais basais opostas; lâmina linear, lanceolada ou ovada, deltada ou 3-5-lobada. Capítulos solitários ou em cimeiras paniculiformes, radiados; pedúnculo fistuloso; brácteas involucrais em 2-5 séries, lineares, lanceoladas, oblongas ou ovadas; receptáculo hemisférico, convexo ou cônico, páleas de ápice agudo ou aristado. Flores do raio neutras; corola do raio verdadeira, amarela, laranja ou vermelha. Flores do disco bissexuadas; corola tubulosa, 5-lacíniada, amarela ou laranja; anteras enegrecidas, castanhas ou amarelas, apêndices do conectivo ovados, base cordada ou sagitada; ramos do estilete lanceolados ou linearlanceolados, ápice acuminado, híspido na face adaxial. Cipselas oblanceoloides ou obovoides, levemente cúbicas ou quadrangulares, enegrecidas, marromacinzentadas ou manchadas, glabras ou pubescentes; pápus coroniforme de escamas fundidas, às vezes 2aristado, ou ausente.

Tithonia diferencia-se dos demais gêneros da tribo por possuir pedúnculos fístulosos (ocos), pápus coroniforme de escamas fundidas, aristadas ou não, ou ausente, e páleas com o ápíce agudo ou aristado (La Duke 1982). Consiste de cerca de 140 espécies, distribuídas no continente americano (Panero 2007). No Brasil e na Bahia, ocorrem duas espécies naturalizadas (Nakajima et al. 2015).

\section{Chave para as espécies}

1. Brácteas involucrais em 3 ou 4 séries, ovadas, as mais externas 6-8 × 3,5-4 mm, com ápice acuminado, as mais internas $16-17 \times 6-10 \mathrm{~mm}$, com ápice arredondado; flores do raio com corola amarela 24.1. T. diversifolia

1'. Brácteas involucrais em 2 séries, lanceoladas, as externas $36 \times 10 \mathrm{~mm}$, as internas $22 \times 9 \mathrm{~mm}$, ambas com ápice acuminado; flores do raio com corola amarelo-alaranjada, laranja ou rubra

24.2. $T$. rotundifolia

24.1. Tithonia diversifolia (Hemsl.) A.Gray, Proc. Amer. Acad. Arts 19(1): 5. 1884. Mirasolia diversifolia Hemsl., Biol. Cent.-Amer., Bot. 2(8): 168, pl. 47. 1881.

Figuras 36, 38H-L e 48A, B.

Nome popular: girassol-americano.

Arbusto ca. 2-4 m alt.; ramos cilíndricos, estriados, glabros ou vilosos. Folhas alternas; pecíolo 1-5,2 cm compr.; lâmina 7,3-11,3 × 2,7-9 cm, cartácea, discolor, 3-5-lobada, raro inteira próxima ao capítulo, ovada, ápice acuminado, margem serreada, base decorrente, face adaxial estrigosa, a abaxial vilosa e glandulosa. Capítulos solitários, terminais, 5-2,4 $\times$ 1,9-2,9 cm; pedúnculo 2-11,4 cm compr., estriado, viloso, bractéolas ca. $10 \times 5 \mathrm{~mm}$, estriadas, ápice acuminado, margem inteira, ovadas; invólucro campanulado, brácteas involucrais 15 , gradativamente maiores, em 3 ou 4 séries, as mais externas $6-8 \times 3,5-$ $4 \mathrm{~mm}$, ovadas, ápice acuminado, margem inteira, estriadas, as mais internas 16-17 × 6-10 mm, ovadas, ápice arredondado, membranáceas, verdes; receptáculo cônico, páleas ca. 7,5 × $3 \mathrm{~mm}$, elípticas, conduplicadas, persistentes, às vezes tripartidas, ápice aristado, margem inteira ou erosa próxima ao ápice. Flores ca. 170. Flores do raio 13, 28-39 mm compr.; corola $25-$ $34 \mathrm{~mm}$ compr. (tubo ca. $2 \mathrm{~mm}$ compr., pubescente), amarela. Flores do disco 8-10 mm compr.; corola 6-7 $\mathrm{mm}$ compr. (tubo $2 \mathrm{~mm}$ compr., pubescente), amarela; anteras ca. $4 \mathrm{~mm}$ compr., enegrecidas, apêndice do conectivo ca. $1 \mathrm{~mm}$ compr., amarelo, ápice arredondado, glanduloso, apêndice basal sagitado, filetes amarelos; estilete ca. 6,2-7 $\mathrm{mm}$ compr., amarelo, ramos do estilete ca. 2,1 $\mathrm{mm}$ compr. Cipselas 5-6 mm compr., obcompressas, obovoides, glabras ou pilosas, enegrecidas, carpopódio inconspícuo; pápus coroniforme de escamas fusionadas de ca. $2 \mathrm{~mm}$ compr., 2 aristas de 3-3,5 mm compr. ou raramente 13 escamas livres de ca. $1 \mathrm{~mm}$ compr.

Ocorre no México e América Central, sendo cultivada no restante da América do Norte, África, Austrália e Ásia (La Duke 1982). O primeiro registro em herbário no Brasil foi em 1969 (Pabst 9291 - RB) e no estado da Bahia em 1982 (Britto 63 - HUEFS) (Species Link 2015). Atualmente, é encontrada em todas as Regiões brasileiras (Nakajima et al. 2015). D6, D7, D10, E6, E9, F6, F9, H8: áreas antropizadas. Encontrada com flores e frutos durante todo o ano. 
Material selecionado - Camacã, 1523'30"S, 39³3' $55^{\prime \prime} \mathrm{W}, 835$ m s.n.m., jul. 2005, A.M. Amorim 5192 (ALCB); Camaçari, $11^{\circ} 48^{\prime} \mathrm{S}, 37^{\circ} 36^{\prime} \mathrm{W}$, abr. 2014, M.L. Guedes 21519 (ALCB); Jacobina, $11^{\circ} 08^{\prime} 37^{\prime \prime S}, 40^{\circ} 29^{\prime} 27^{\prime \prime} \mathrm{W}, 873$ m s.n.m., jun. 2011, M. Alves et al. 31 (ALCB); Lençóis, 40²9'27"S, 4125'05"W, $760 \mathrm{~m}$ s.n.m., out. 2014, N. Roque et al. 4482 (ALCB); Morro do Chapéu,

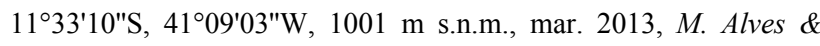
Borges, R.L. 139 (ALCB, HUEFS); Mucugê, maio 2011, M. Alves

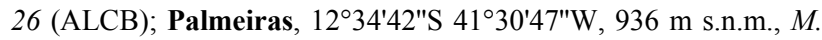
Alves et al. 111 (ALCB, HUEFS); Salvador, jun. 1994, M.L. Guedes s.n. (ALCB 25243).

Tithonia diversifolia se dispersou rapidamente no Brasil, da coleta de uma planta cultivada no Rio de Janeiro em 1969 para 172 registros em 2014, já presente em todas as Regiões (Species Link 2015). Na Bahia, $T$. diversifolia é encontrada tanto como ornamental (cultivada) como ruderal, em beiras de estradas e terrenos baldios.

24.2. Tithonia rotundifolia (Mill.) S.F.Blake, Contr. Gray Herb. 52: 41. 1917. Tagetes rotundifolia Mill., Gard. Dict. (ed. 8.) n. 4. 1768.

Figuras 37 e 48C, D.

Arbusto ca. 1-2,5 m alt.; ramos cilíndricos, estriados, pubescentes. Folhas alternas; pecíolo 1,34,8 cm compr.; lâmina $(4,2) 7,9-11,9 \times(2,8) 4,3-8 \mathrm{~cm}$, cartácea, discolor, 3-5-lobada, raro inteira próxima ao capítulo, ovada, ápice acuminado ou caudado, margem crenada ou serreada, base decorrente, face adaxial estrigosa, a abaxial pubescente, às vezes tomentosa nas nervações, glandulosa. Capítulos solitários, terminais, 1,9-2,7 × 1,8-3,6 cm; pedúnculo 15,5-28,9 cm compr., fistuloso, estriado, pubescente; invólucro levemente campanulado, brácteas involucrais $12-15$, em 2 séries, as externas ca. $36 \times$

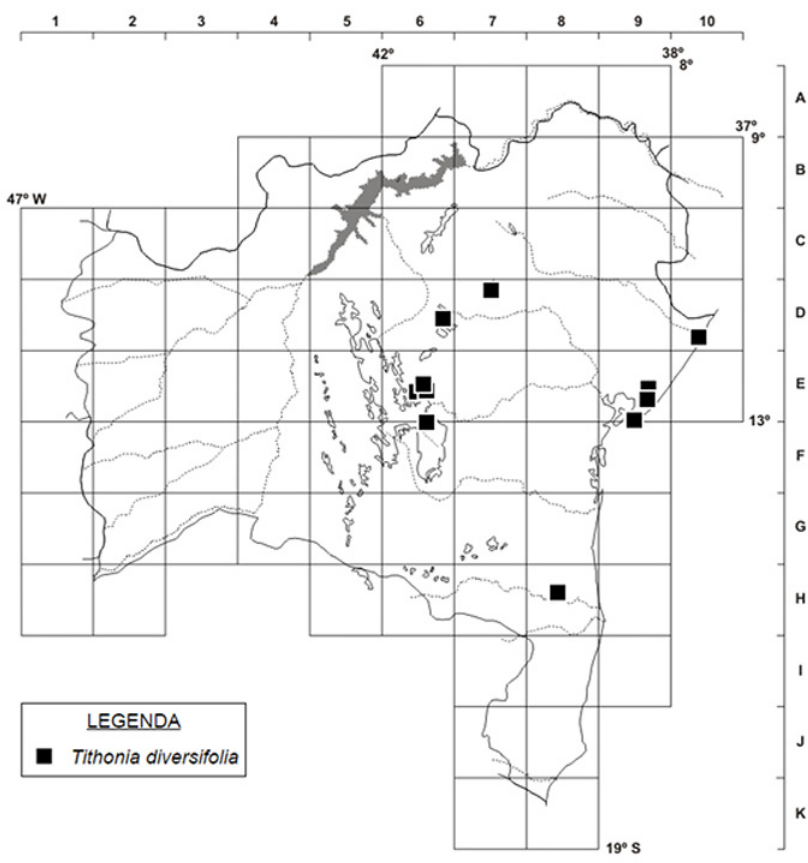

Figura 36. Mapa de distribuição geográfica de Tithonia diversifolia no estado da Bahia.
$10 \mathrm{~mm}$, as internas ca. $22 \times 9 \mathrm{~mm}$, lanceoladas, ápice acuminado, margem inteira, verdes; receptáculo convexo, páleas 18-19 × 4-6 mm, lanceoladas, conduplicadas, persistentes, às vezes tripartidas, ápice aristado, margem inteira ou erosa próxima ao ápice. Flores 153-158. Flores do raio 8-13, 34-37 mm compr.; corola 27-30 mm compr. (tubo ca. $2 \mathrm{~mm}$ compr., pubescente), amarelo-alaranjada, laranja ou rubra. Flores do disco 15-16 mm compr.; corola ca. $10 \mathrm{~mm}$ compr. (ca. $1 \mathrm{~mm}$ compr., pubescente, garganta fortemente dilatada na maturidade), amarela; anteras ca. $6 \mathrm{~mm}$ compr., enegrecidas, apêndice do conectivo ca. 1,2 $\mathrm{mm}$ compr., amarelo, ápice acuminado, apêndice basal sagitado, filetes amarelos; estilete ca. $8 \mathrm{~mm}$ compr., dilatado na base, amarelo, ramos do estilete ca. $3 \mathrm{~mm}$ compr. Cipselas $7-8 \mathrm{~mm}$ compr., levemente compressas, oblanceoloides, seríceas, cinza, castanhas ou enegrecidas, carpopódio inconspícuo; pápus coroniforme de escamas fusionadas, ca. $2 \mathrm{~mm}$ compr., com 2 aristas desiguais de ca. 4 e $8 \mathrm{~mm}$ compr., pubescentes.

Ocorre naturalmente do México ao Panamá, mas foi introduzida em todo o mundo, tendo se naturalizado em muitos lugares (La Duke 1982). No Brasil, possui registros para a Bahia e estados do Sudeste e Sul (Nakajima et al. 2015). D6, D7, E5, E6, E7, E9, F6, F7, F9: áreas antropizadas. Encontrada com flores e frutos durante todo o ano.

Material selecionado - Jacobina, $11^{\circ} 10^{\prime} 11^{\prime \prime} \mathrm{S}, 40^{\circ} 30^{\prime} 23^{\prime \prime} \mathrm{W}$, 491 m s.n.m., jun. 2011, M. Alves, et al. 30 (ALCB); Morro do Chapéu, $11^{\circ} 33^{\prime} 10^{\prime \prime S}, 41^{\circ} 09^{\prime} 02^{\prime \prime} \mathrm{W}, 1002$ m s.n.m., abr. 2013, M. Alves 136 (ALCB, HUEFS); Mucugê, fev. 2012, T.L. Vieira \& M.F. Santos 75 (ALCB); Nova Itarana, jul. 1982, K.B. Britto 63 (HUEFS); Salvador, $12^{\circ} 56^{\prime} \mathrm{S}, 38^{\circ} 21^{\prime} \mathrm{W}$, jul. 1996, M.L. Guedes 3874 (ALCB).

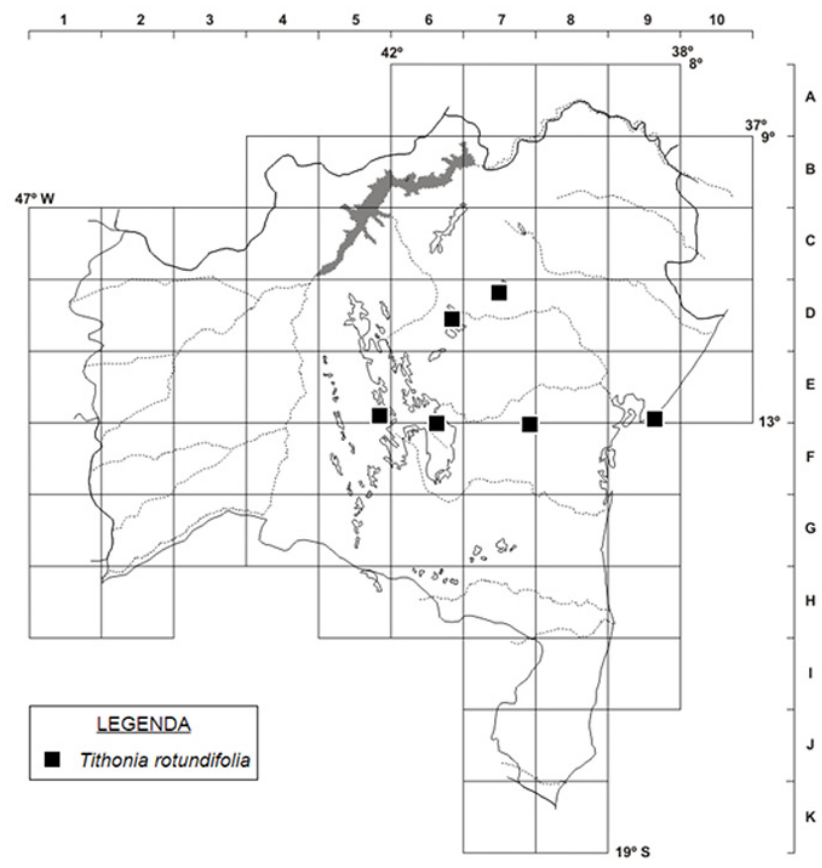

Figura 37. Mapa de distribuição geográfica de Tithonia rotundifolia no estado da Bahia. 
Os primeiros registros para a espécie no Brasil são de Brasília, em 1971 (Taxonomy Class of Universidade de Brasília 17 e 302 - UB), chegando à Bahia em 1979 (King 7996 - CEPEC) (Species Link 2015), onde pode ser encontrada em beiras de estradas e terrenos baldios, sendo menos comum que $T$. diversifolia.

\section{Verbesina L.}

Ervas eretas anuais ou perenes, arbustos ou árvores. Folhas alternas, opostas ou em rosetas, algumas vezes com pecíolo alado decorrente ou sésseis; lâmina linear, lanceolada, ovada, suborbicular, sagitada, deltada, inteira ou profundamente lobada,

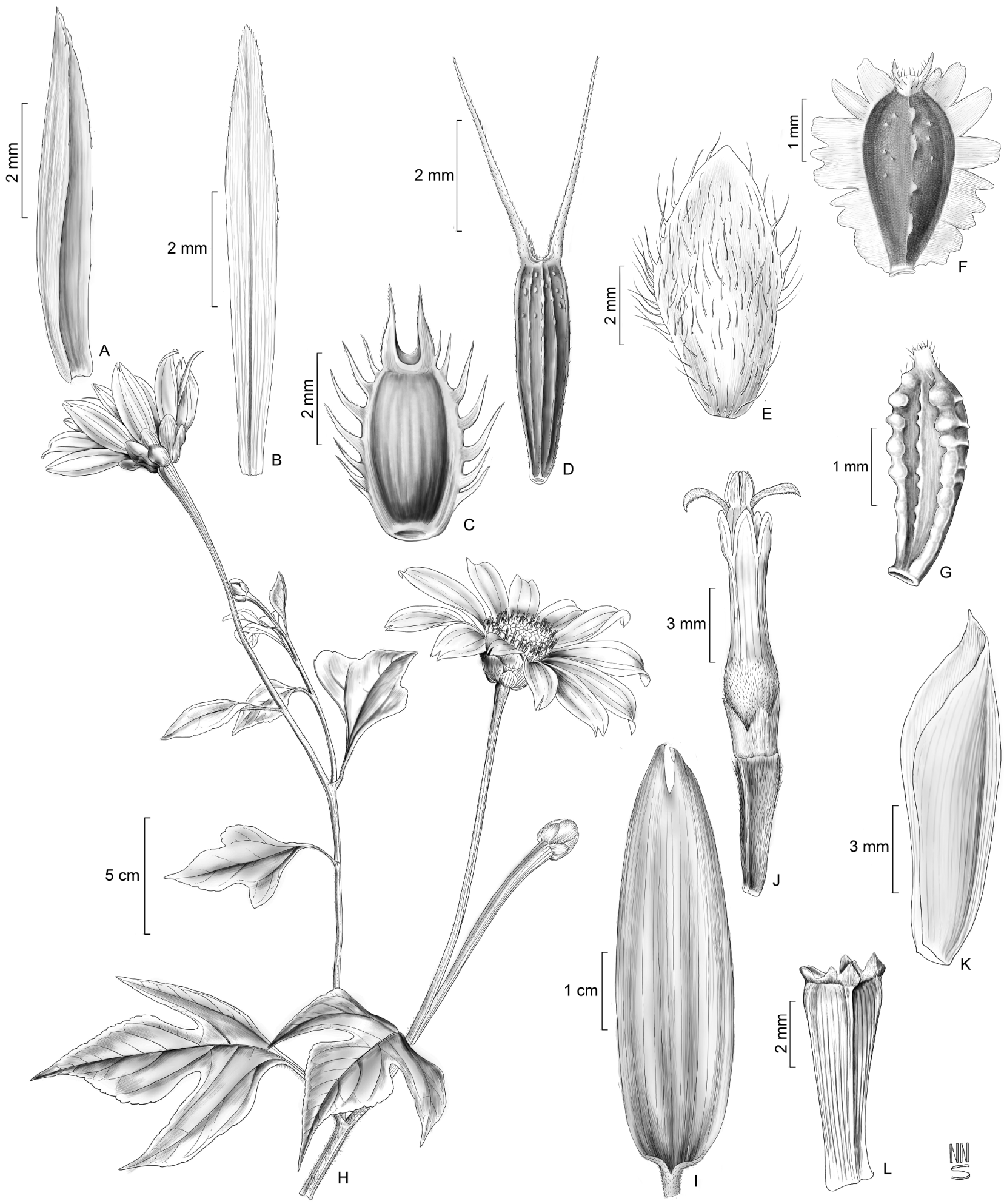

Figura 38. A-D. Synedrella nodiflora: A- pálea conduplicada; B- pálea plana; C- cipsela da flor do raio com alas laceradas de ápice acuminado; D- cipsela da flor do disco. E-G. Synedrellopsis grisebachii: E- bráctea involucral setosa; F- cipsela obcompressa com alas laceradas; G- cipsela plano-convexa sem alas. H-L. Tithonia diversifolia: H- ramo com capítulos; I- corola da flor neutra do raio; J- flor do disco; K- pálea; L- apêndice estéril da flor do raio. (A-D- Alves 6; E-G- Guedes 7545; H-L-Alves 139). 
raro perfoliada. Capítulos solitários, às vezes escaposos, ou em cimeiras paniculiformes ou corimbiformes, terminais, discoides ou radiados; brácteas involucrais em 2 ou 3 séries, lanceoladas; receptáculo plano, cônico ou convexo, raramente globoso, paleáceo. Flores do raio femininas, neutras ou ausentes; corola do raio verdadeira, alva, laranja, vermelha ou amarela. Flores do disco bissexuadas; corola tubulosa, 5-laciniada, geralmente amarela ou alva; anteras castanhas ou enegrecidas, apêndice com ou sem glândulas; ramos do estilete geralmente agudos. Cipselas compressas, amplamente obovoides, oblanceoloides ou estreitamente cuneadas, com alas simétricas ou assimétricas; pápus de 2 aristas eretas, raramente uncinadas, às vezes as cipselas do raio com 3 aristas, raramente sem aristas.

Verbesina pode ser reconhecido pelas cipselas compressas, aladas e pápus geralmente com duas aristas eretas (Panero 2007). Possui cerca de 300 espécies, distribuídas nas Américas, com centro de diversidade no México e Andes (Panero 2007). No Brasil, são registradas 11 espécies (Nakajima et al. 2015), cinco delas ocorrem no estado da Bahia. Podemos observar dois padrões para as espécies no estado: aquelas com folhas lobadas, corolas alvas, amplamente distribuídas em bordas de mata e beiras de estrada e que apresentam floração em conjunto e aquelas com folhas inteiras e corolas amarelas, que ocorrem em áreas de campo rupestre, acima de 1200 m s.n.m.

\section{Chave para as espécies}

1. Lâmina foliar lobada; flores com corola alva.

2. Lâmina foliar 7-11-lobada; capítulos discoides; corola com lacínias reflexas

25.2. V. bipinnatifida

2'. Lâmina foliar 3-5(7)-lobada, raro inteira; capítulos radiados; corola das flores do disco com lacínias eretas ......... 25.5. V. macrophylla

1'. Lâmina foliar inteira; flores com corola amarela.

3. Lâmina foliar obovada, ápice arredondado, margem crenada ou revoluta, base cuneada, face abaxial estrigosa

25.1. V. baccharifolia

3'. Lâmina foliar estreito-elíptica ou elíptica, ápice agudo, acuminado ou caudado, margem serreada nos $2 / 3$ apicais, às vezes revoluta, base atenuada a decorrente, face abaxial glabrescente ou serícea.

4. Lâmina foliar estreito-elíptica, face adaxial glabra, às vezes serícea nas nervações 25.3. $V$. glabrata

4'. Lâmina foliar elíptica, face adaxial estrigosa . 25.4. V. luetzelburgii

25.1. Verbesina baccharifolia Mattf., Notizbl. Bot. Gart. Berlin-Dahlem 9: 387. 1925.

Figuras 39 e 48E.

Arbusto ca. 2-3 m alt.; ramos cilíndricos, estriados, estrigosos ou glabrescentes. Folhas alternas, sésseis; lâmina 4-6,3 × 2,4-3 cm, coriácea, discolor, obovada, ápice arredondado, margem crenada, às vezes revoluta, base cuneada, estrigosa em ambas as faces. Capitulescências corimbiformes; pedúnculo $0,7-2 \mathrm{~cm}$ compr. Capítulos $0,9-1,1 \times 1-1,4 \mathrm{~cm}$, radiados; invólucro campanulado, brácteas involucrais subiguais, ca. 25 , em 2 ou 3 séries, 4-5 × ca. $1 \mathrm{~mm}$, lanceoladas, ápice agudo, margem inteira, pubescentes, verdes; receptáculo levemente cônico, páleas $7-7,5 \times$ ca. $2 \mathrm{~mm}$, lanceoladas, conduplicadas, persistentes, carenadas, ápice obtuso, pubescente, margem inteira. Flores ca. 57. Flores do raio 7, ca. $10 \mathrm{~mm}$ compr., estéreis; corola do raio verdadeira, ca. $8 \mathrm{~mm}$ compr. (tubo ca. $1 \mathrm{~mm}$ compr.), 2- ou 3-lobada, amarela. Flores do disco ca. 8 $\mathrm{mm}$ compr.; corola ca. $6 \mathrm{~mm}$ compr. (tubo ca. $1 \mathrm{~mm}$ compr., pubescente), amarela; anteras 2,2-2,5 $\mathrm{mm}$ compr., enegrecidas, apêndice do conectivo ca. 0,2 $\mathrm{mm}$ compr., ovado, ápice agudo, amarelo, apêndice basal sagitado, filetes amarelos; estilete ca. 6,5 mm compr., amarelo, ramos do estilete ca. 1,5 $\mathrm{mm}$ compr. Cipselas ca. $4 \mathrm{~mm}$ compr., obovoides, enegrecidas, com alas inteiras de até $1 \mathrm{~mm}$ larg., hialinas, carpopódio inconspícuo; pápus com 2 aristas de 2,5-3 mm compr., lanceoladas, glabrescentes.

Endêmica da Bahia (Nakajima et al. 2015). F5, F6: campo rupestre. Encontrada com flores e frutos de maio a novembro.

Material selecionado - Abaíra, $13^{\circ} 20^{\prime} \mathrm{S}, 41^{\circ} 53^{\prime} \mathrm{W}, 1800 \mathrm{~m}$ s.n.m., W. Ganev 363 (ALCB, HUEFS); Rio de Contas, 1322'07"S, 41 ${ }^{\circ} 53^{\prime} 03^{\prime \prime W}, 1800$ m s.n.m., R.M. Harley et al. PCD 4307 (ALCB, HUEFS).

Verbesina baccharifolia apresenta menos que dez coletas na Bahia. Dentre as espécies com corola amarela que ocorrem no estado, pode ser reconhecida pela lâmina foliar obovada com ápice arredondado, margem crenada ou revoluta, base cuneada e face abaxial estrigosa.

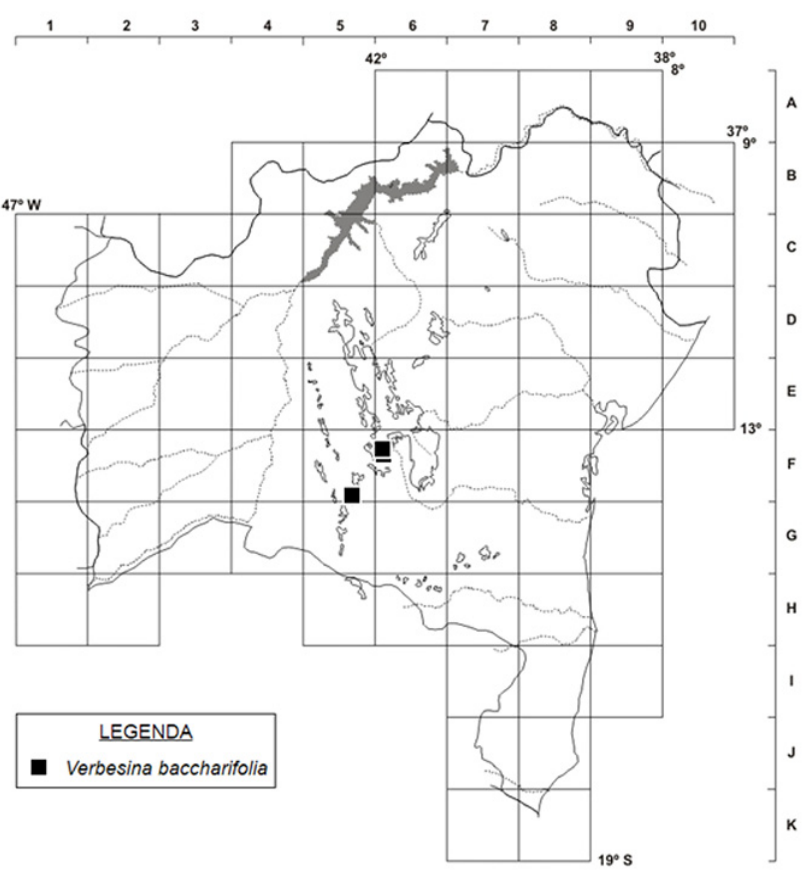

Figura 39. Mapa de distribuição geográfica de Verbesina baccharifolia no estado da Bahia. 
25.2. Verbesina bipinnatifida Baker in Martius \& Eichler, Fl. Bras. 6(3): 213. 1884.

Figuras 40 e $48 \mathrm{~F}$.

Arbusto até $4 \mathrm{~m}$ alt.; ramos cilíndricos, estriados, seríceos ou glabrescentes. Folhas alternas; pecíolo 2,2-5,9 cm compr.; lâmina $(4,4) 6,8-14,3(18,3) \times 6,6$ 12,2 cm, cartácea, discolor, 7-11-lobada, lobos inteiros ou pinatífidos, ápice acuminado, margem denteada, base decorrente, face adaxial estrigosa, a abaxial serícea. Capitulescências corimbiformes; pedúnculo 0,1-0,8 cm compr., bractéola $1-3,2,1 \times 0,3-0,5 \mathrm{~mm}$. Capítulos $0,7-0,9 \times 0,3-0,5 \mathrm{~cm}$, discoides; invólucro cilíndrico, brácteas involucrais subiguais 8-12, em 2 ou 3 séries, 3-5 × ca. $1 \mathrm{~mm}$, lanceoladas, ápice acuminado, margem inteira, pubescentes, verdes; receptáculo levemente cônico, páleas 5,5-6 × 2-2,5 $\mathrm{mm}$, obovadas, conduplicadas, persistentes, ápice acuminado, margem inteira, ciliada. Flores 8-15, 7,5$9 \mathrm{~mm}$ compr.; corola 4-4,5 mm compr. (tubo ca. $1 \mathrm{~mm}$ compr., pubescente), alva, lacínias reflexas; anteras 2 2,1 mm compr., enegrecidas, apêndice do conectivo ca. 0,2 mm compr., ovado, enegrecido, ápice agudo, apêndice basal sagitado, filetes alvos; estilete 3-4 mm compr., alvo, ramos do estilete ca. $1 \mathrm{~mm}$ compr., ápice agudo, pubescente. Cipselas 3-4 × 1-1,5 mm compr., obovoides, estipitadas, enegrecidas, com alas inteiras até $1 \mathrm{~mm}$ larg., glabrescentes, carpopódio inconspícuo; pápus com 2 aristas de 2,1-3 mm compr., lanceoladas, glabrescentes.

Era conhecida apenas para Minas Gerais (Nakajima et al. 2015), sendo este o seu primeiro registro na Bahia. E5, F6, G4, G5, J7: cerrado. Encontrada com flores e frutos em maio.

Material selecionado - Abaíra, $13^{\circ} 17^{\prime} \mathrm{S}, 41^{\circ} 50^{\prime \prime} \mathrm{W}$, abr. 2006, M.L. Guedes et al. 12291 (ALCB); Caetité, 14²1'10"S,

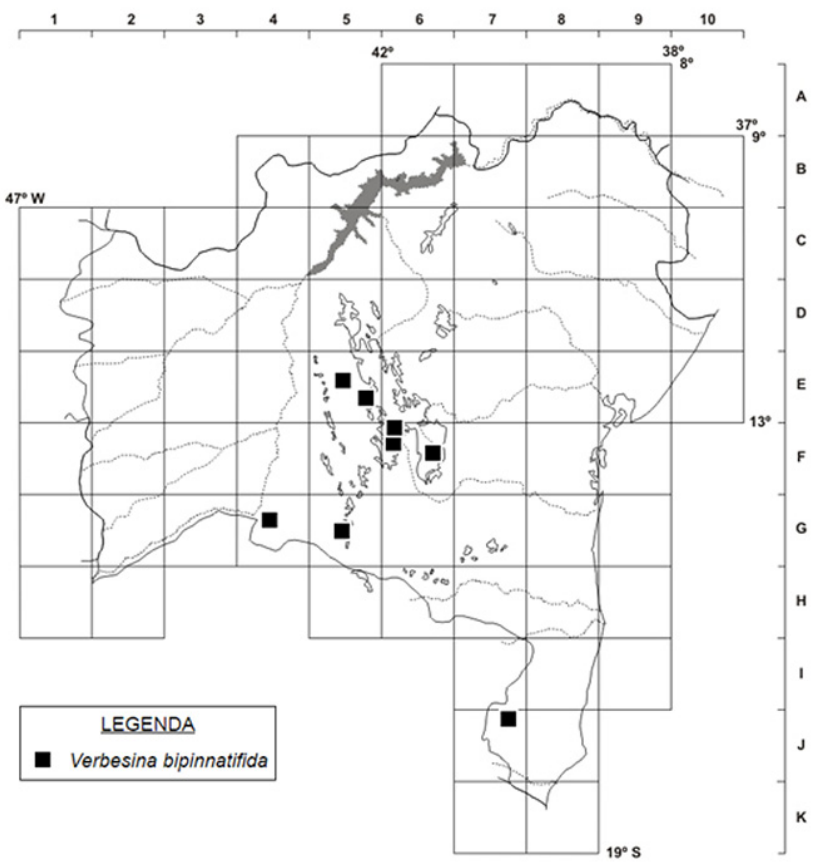

Figura 40. Mapa de distribuição geográfica de Verbesina bipinnatifida no estado da Bahia.
42³2'18"W, 1001 m s.n.m., M.L. Guedes et al. 14267 (ALCB); Gentio do Ouro, $11^{\circ} 23^{\prime} 55^{\prime \prime} \mathrm{S}, 42^{\circ} 32^{\prime} 8^{\prime \prime} \mathrm{W}$, maio 2002, $R$. Tourinho et al. 20 (HUEFS); Ibicoara, jul. 2013, M. Alves et al. 272 (ALCB, HUEFS); Ibitiara, maio 1957, R.P. Lordêlo 57-442 (ALCB); Itanhém, $17^{\circ} 07^{\prime} 50,8^{\prime \prime} \mathrm{S}, 40^{\circ} 14^{\prime} 47,7^{\prime} \mathrm{W}, 451 \mathrm{~m}$ s.n.m., ago. 2004, J.R. Stehmann 3826 (BHCB); Licínio de Almeida, 14²9'52"S, 42³2'44"W, 972 m s.n.m., maio 2012, M. Alves et al. 198 (ALCB, HUEFS); Piatã, 130' $50 " \mathrm{~S}, 41^{\circ} 48^{\prime} 51^{\prime \prime W}, 1349$ m s.n.m., jul. 2013, M. Alves et al. 286 (ALCB, HUEFS).

Verbesina bipinnatifida é similiar a $V$. macrophylla, diferenciando-se, principalmente, por possuir capítulos discoides (vs. radiados).

\subsection{Verbesina glabrata Hook. \& Arn., J. Bot. 3:} 315. 1841 .

Figuras 41 e 49A; Baker (1884: prancha 66).

Arbusto ca. $4 \mathrm{~m}$ alt.; ramos cilíndricos, estriados, seríceos ou glabros. Folhas alternas; pecíolo $(1,2) 1,6-$ $3,1 \mathrm{~cm}$ compr.; lâmina 8,5-14,9(22,9) × 2,7-4,9(7) $\mathrm{cm}$, cartácea, discolor, estreito-elíptica, ápice acuminado ou caudado, margem serreada nos $2 / 3$ apicais, às vezes revoluta, base atenuada ou decorrente, face adaxial glabra, às vezes serícea nas nervações, a abaxial serícea ou glabrescente. Capitulescências corimbiformes; pedúnculo 0,92,8(4,1) cm compr.; bractéolas 3-7, 1,5-3,1 × 0,5 mm. Capítulos $0,7-1,1 \times 0,7-1,3 \mathrm{~cm}$, radiados; invólucro campanulado, brácteas involucrais subiguais, 17-20, em 2 ou 3 séries, $2-3 \times$ ca. $1 \mathrm{~mm}$, lanceoladas, ápice agudo ou obtuso, margem inteira, verde-claras; receptáculo cônico, páleas ca. $5 \times 2 \mathrm{~mm}$, obovadas, conduplicadas, persistentes, carenadas, ápice agudo, margem inteira, às vezes sinuosa. Flores 59-72. Flores do raio $8-10,5,5-11 \mathrm{~mm}$ compr., femininas; corola do raio verdadeira, 4-10 $\mathrm{mm}$ compr. (tubo ca. $1 \mathrm{~mm}$ compr., pubescente), 3-lobada, amarela. Flores do disco 5-6,5 mm compr.; corola ca. $4 \mathrm{~mm}$ compr. (tubo ca. $1 \mathrm{~mm}$ compr., pubescente), amarela; anteras 2-2,1 $\mathrm{mm}$ compr., enegrecidas, apêndice do conectivo ca. 0,2 mm compr., ovado, enegrecido, ápice agudo, apêndice basal sagitado, filetes amarelos; estilete 4-4,3 $\mathrm{mm}$ compr., amarelo, ramos do estilete ca. $1 \mathrm{~mm}$ compr., ápice agudo. Cipselas 4-6 mm compr., obovoides, enegrecidas, com alas inteiras de até $1 \mathrm{~mm}$ larg., hialinas, glabrescentes, carpopódio inconspícuo; pápus com 2 aristas de 2-3 mm compr., lanceoladas, glabrescentes.

Endêmica do Brasil, nas Regiões Nordeste (BA), Centro-Oeste (GO, MS), Sudeste (MG, RJ, SP) e Sul (PR, RS, SC) (Nakajima et al. 2015). D6, D7, E6, F6, F8: campo rupestre. Encontrada com flores e frutos de maio a novembro.

Material selecionado - Amargosa, $13^{\circ} 10^{\prime} \mathrm{S}, 39^{\circ} 09^{\prime} \mathrm{W}$, abr. 2007, J.L. Paixão et al. 1148 (ALCB, HUEFS); Miguel Calmon, $11^{\circ} 20^{\prime} \mathrm{S}, 40^{\circ} 31^{\prime} \mathrm{W}$, ago. 2006, M.L. Guedes et al. 12701 (ALCB); Morro do Chapéu, $11^{\circ} 33^{\prime} 00^{\prime \prime S}, 41^{\circ} 09^{\prime} 22^{\prime \prime} \mathrm{W}$, set. 1956, E. Pereira

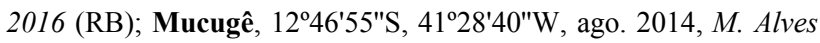
et al. 345 (ALCB, HUEFS); Palmeiras, out. 1999, A.A. Conceição 607 (ALCB). 


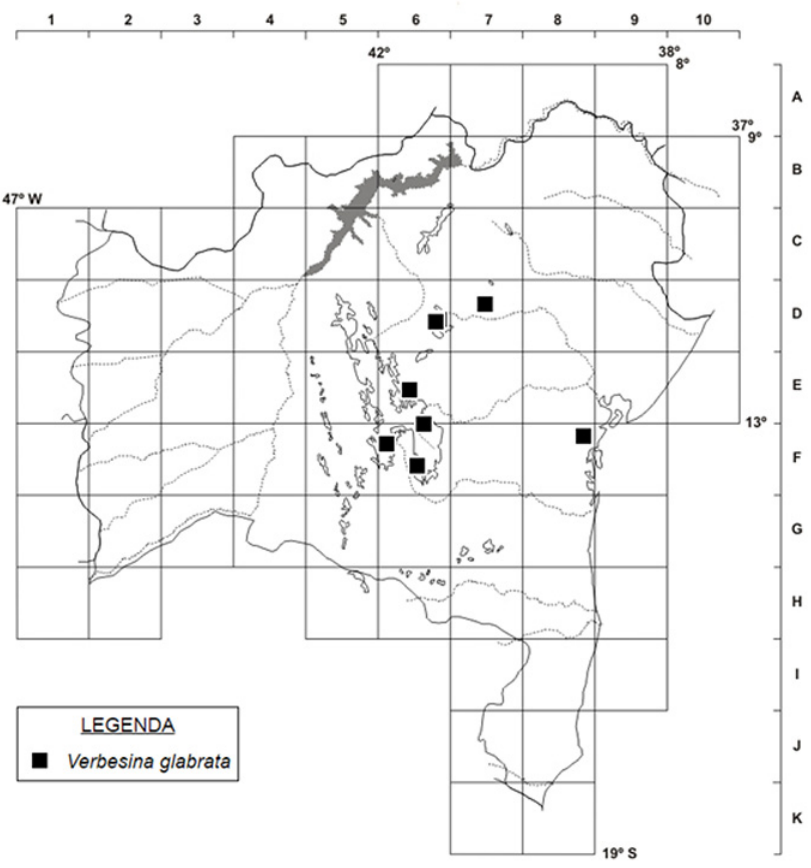

Figura 41. Mapa de distribuição geográfica de Verbesina glabrata no estado da Bahia.

Alguns espécimes de Verbesina glabrata na Bahia apresentaram lâminas foliares seríceas na face abaxial (Oliveira \& Santos 107 e Alves et. al. 338) em vez de glabrescentes, o que até então não havia sido documentado na espécie.

25.4. Verbesina luetzelburgii Mattf., Notizbl. Bot. Gart. Berlin-Dahlem 9: 389. 1925.

Figuras 42 e 49B.

Arbusto 1,2-3,5 m alt.; ramos cilíndricos, estriados, seríceos. Folhas alternas, sésseis ou pecioladas (pecíolo 0,2-2 cm compr.); lâmina 5$10,6(15,7) \times 2,2-5,1(8) \mathrm{cm}$, coriácea, discolor, elíptica, ápice agudo ou acuminado, margem serreada nos $2 / 3$ apicais, às vezes revoluta, base atenuada ou decorrente, face adaxial estrigosa, a abaxial serícea. Capitulescências corimbiformes; pedúnculo $0,4-3 \mathrm{~cm}$ compr., bractéolas $1-3,5 \times$ ca. $1 \mathrm{~mm}$ Capítulos 0,7-1 $\times \quad 0,6-0,8 \mathrm{~cm}$, radiados; invólucro campanulado, brácteas involucrais subiguais, 17-24, em 2 ou 3 séries, 4-5 $\times$ ca. $1 \mathrm{~mm}$, lanceoladas, ápice agudo ou obtuso, margem inteira, serícea ou glabrescente, verdes. Receptáculo cônico, páleas lanceoladas, conduplicadas, persistentes, ca. $6 \times 2 \mathrm{~mm}$, carenadas, ápice agudo, margem inteira, ciliada, pubescentes. Flores 60-62. Flores do raio 5-9, 6-12 mm compr., femininas; corola 5-10 mm compr. (tubo ca. $2 \mathrm{~mm}$ compr.), amarela. Flores do disco, 6-8 $\mathrm{mm}$ compr.; corola ca. $5 \mathrm{~mm}$ compr. (tubo ca. $1 \mathrm{~mm}$ compr.), amarela; anteras 2,3$2,5 \mathrm{~mm}$ compr., enegrecidas, apêndice do conectivo ca. $0,2 \mathrm{~mm}$ compr., enegrecido, obovado, ápice agudo, apêndice basal sagitado, filetes amarelos; estilete 4-6 $\mathrm{mm}$ compr., amarelo, ramos do estilete 1-2 $\mathrm{mm}$ compr., ápice agudo, papiloso. Cipselas $3-5 \mathrm{~mm}$ compr., obovoides, enegrecidas, com alas inteiras, hialinas, até $1 \mathrm{~mm}$ larg., glabrescentes, carpopódio inconspícuo; pápus com 2(3) aristas lanceoladas, pubescentes, ca. $3 \mathrm{~mm}$ compr.

Endêmica do estado da Bahia (Nakajima et al. 2015). F6: campo rupestre. Encontrada com flores e frutos no mês de março.

Material selecionado - Abaíra, $13^{\circ} 16^{\prime} \mathrm{S}, 41^{\circ} 54^{\prime} \mathrm{W}, 1650 \mathrm{~m}$ s.n.m., jul. 1992, W. Ganev 650 (HUEFS); Barra da Estiva, $13^{\circ} 35^{\prime} \mathrm{S}, 41^{\circ} 27^{\prime} \mathrm{W}$, mar. 1980, R.M. Harley et al. 20741 (RB); Piatã, $13^{\circ} 17^{\prime} \mathrm{S}, 41^{\circ} 53^{\prime} \mathrm{W}, 1185 \mathrm{~m}$ s.n.m., set. 1996, R.M. Harley et al.

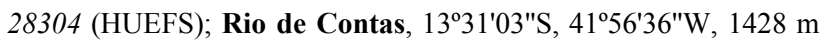
s.n.m., ago. 2014, F. Hurbath et al. 673 (ALCB); Rio do Pires, $13^{\circ} 15^{\prime} 50^{\prime \prime S}, 41^{\circ} 55^{\prime} 4^{\prime \prime W}, 1750 \mathrm{~m}$ s.n.m., nov. 2008, F.H.F Nascimento 629 (HUEFS).

Os espécimes coletados e analisados apresentaram variação morfológica no indumento da lâmina foliar.

25.5. Verbesina macrophylla (Cass.) S.F.Blake, Bull. Torrey Bot. Club 51: 430. 1924. Ditrichum macrophyllum Cass., Bull. Soc. Philom. Paris: 33. 1817.

$=$ Verbesina diversifolia DC., Prodr. 5: 615. 1836.

Figuras 43 e 49C. Baker (1884: prancha 65).

Nome popular: assa-peixe.

Arbusto 1-3 m alt.; ramos cilíndricos, estriados, às vezes alados, seríceos ou glabrescentes. Folhas alternas; pecíolo 2,2-5,9 cm compr.; lâmina 9,7$15,7(18,5) \times 4,1-15,2(20) \mathrm{cm}$, cartácea, discolor, 35(7)-lobada, raro inteira geralmente próxima à capitulescência, ápice acuminado, margem denteada, base decorrente, face adaxial estrigosa, a abaxial serícea. Capitulescências corimbiformes; pedúnculo 0,4-1,3 cm compr., bractéolas $1-3,0,15-0,3 \times$ ca. 0,5 $\mathrm{mm}$. Capítulos $0,5-0,6 \times 0,2-0,3 \mathrm{~cm}$, radiados; invólucro cilíndrico, brácteas involucrais subiguais 7 9, em 2 ou 3 séries, $3-4 \times$ ca. $1 \mathrm{~mm}$, lanceoladas, ápice

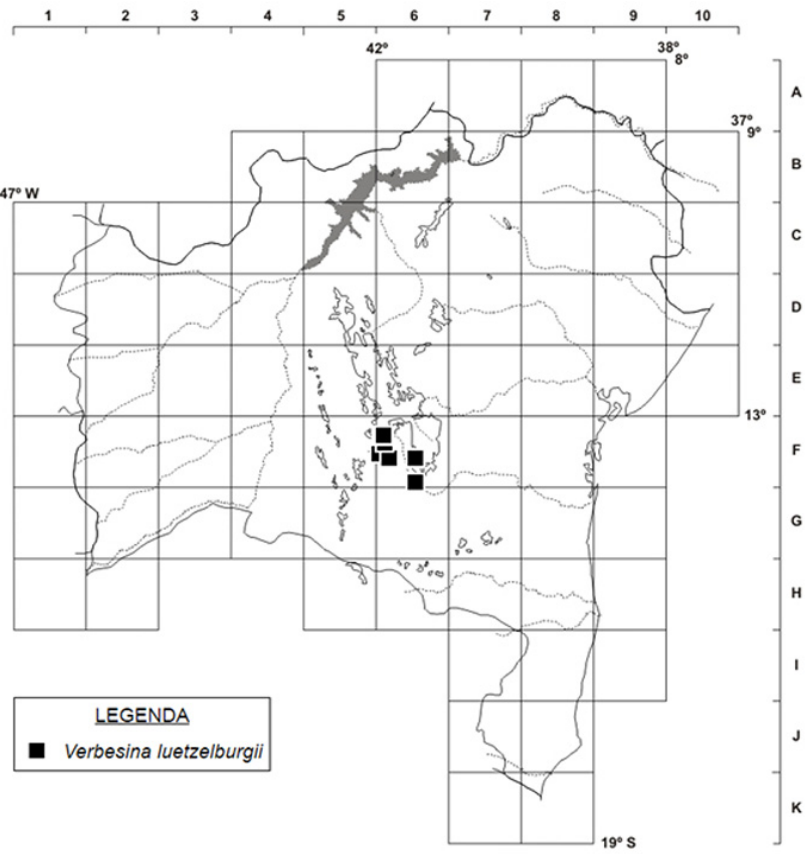

Figura 42. Mapa de distribuição geográfica de Verbesina luetzelburgii no estado da Bahia. 
acuminado, margem inteira, ciliada, verde-claras; receptáculo cônico, páleas ca. $5 \times 2 \mathrm{~mm}$, obovadas, conduplicadas, persistentes, ápice acuminado, margem inteira com tricomas esparsos. Flores 17-25. Flores do raio 4-7, 5-6 mm compr., femininas; corola $4-5,5 \mathrm{~mm}$ compr. (tubo ca. $2 \mathrm{~mm}$ compr., pubescente), 2-lobada, alva. Flores do disco 6-7 mm compr.; corola ca. $3 \mathrm{~mm}$ compr. (tubo ca. $1 \mathrm{~mm}$ compr., pubescente), alva, lacínias eretas; anteras 1,2-1,5 $\mathrm{mm}$ compr., enegrecidas, apêndice do conectivo ca. 0,2 $\mathrm{mm}$ compr., ovado, enegrecido, ápice agudo, apêndice basal sagitado, filetes alvos; estilete ca. $3 \mathrm{~mm}$ compr., alvo, ramos do estilete ca. 1,2 $\mathrm{mm}$ compr., ápice agudo com papilas. Cipselas 2,5-4,1 mm compr., obovoides, estipitadas, enegrecidas, com alas inteiras até $1,5 \mathrm{~mm}$ larg., às vezes com margem ciliada ou erosa, glabrescente, carpopódio inconspícuo; pápus com 2 aristas de 1-2,2 mm compr., lanceoladas, pubescentes.

Verbesina macrophylla não é endêmica do Brasil e é amplamente distribuída no Nordeste e Sudeste (Nakajima et al. 2015). C7, C8, D6, D7, D8, E6, E7, E8, E9, F6, F7, F8, F9, G5, G7, G8, H8, I8: áreas antropizadas, em mata atlântica e cerrado. Encontrada com flores e frutos durante todo o ano.

Material selecionado - Alagoinhas, $12^{\circ} 08^{\prime} 00^{\prime \prime} \mathrm{S}, 38^{\circ} 26^{\prime} 00^{\prime \prime} \mathrm{W}$, maio 2000, L.E. Figueroa et al. 14 (ALCB); Amargosa, 130ㅣ'S, 39³6'W, out. 2005, M.A.A. Costa et al. 58 (ALCB); Araçás, $12^{\circ} 07^{\prime} 23^{\prime \prime S}, 38^{\circ} 8^{\prime} 9^{\prime} \mathrm{W}$, jul. 2013, L.V. Vasconcelos et al. 561 (HUEFS); Baixa Grande, $11^{\circ} 58^{\prime} \mathrm{S}, 40^{\circ} 14^{\prime} \mathrm{W}$, ago. 1981, G.C.P. Pinto 253-81 (ALCB); Boa Nova, 14'22'17"S, 40'14'53"W, $811 \mathrm{~m}$ s.n.m., jul. 2013, M. Alves et al. 245 (ALCB, HUEFS); Belmonte, jun. 1999, M.L. Guedes et al. 6322 (ALCB); Cachoeira, set. 1992, M.L. Guedes s.n. (ALCB 23799); Campo Formoso, 10³0'49"W, $40^{\circ} 18^{\prime} 25^{\prime \prime W}, 670$ m s.n.m., E. Miranda-Silva et al. 196 (HUEFS); Conceição de Feira, $12^{\circ} 32^{\prime} \mathrm{S}, 3^{\circ} 03^{\prime} \mathrm{W}$, abr. 1905, L.R. Noblick

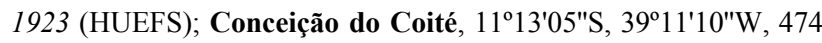
m s.n.m., D.N. Carvalho 14 (ALCB); Conceição do Jacuípe, $12^{\circ} 19^{\prime} 00^{\prime \prime S}, 38^{\circ} 46^{\prime} 00^{\prime \prime} \mathrm{W}$, abr. 1974, G.C.P. Pinto 42402 (ALCB 4430, RB); Cruz das Almas, fev. 1952, G.C.P. Pinto s.n. (ALCB 7202); Elísio Medrado, maio 2015, A. Gandara 111 (ALCB); Entre Rios, ago. 2009, N. Roque et al. 2194. (ALCB); Eunápolis, $16^{\circ} 16^{\prime} \mathrm{S}, 39^{\circ} 34^{\prime} \mathrm{W}$, M.L. Guedes 7626 (ALCB); Feira de Santana, $12^{\circ} 11^{\prime} \mathrm{S}, 38^{\circ} 58^{\prime \prime} \mathrm{W}$, jul. 2005, E. Melo et al. 3965 (HUEFS); Igrapiúna, 13054'19"S, 39²'28"W, 153 m s.n.m., M.L. Guedes et al. 17456 (ALCB); Ilhéus, set. 1998, L.C.B. Costa 65 (ALCB); Itaberaba, $12^{\circ} 13^{\prime} 12^{\prime \prime} \mathrm{S}, 40^{\circ} 48^{\prime} 35^{\prime \prime} \mathrm{W}$, set. 1999 M.M. Silva et al. 259 (HUEFS); Itaetê, abr. 2001, D.M. Loureiro et al. 103 (ALCB); Itagibá, $14^{\circ} 10^{\prime} 02^{\prime \prime} \mathrm{S}, 39^{\circ} 43^{\prime} 20^{\prime \prime} \mathrm{W}$, set. 2008, C.E. Ramos et al. 318 (ALCB); Itapebi, $15^{\circ} 57^{\prime} 03^{\prime \prime S}, 3^{\circ} 32^{\prime} 02^{\prime \prime W}$, ago. 1971, T.S. Santos 1791 (CEPEC, RB); Jacobina, 1109'59"S, 40³0'23"W, ago. 2001, F.R. Nonato et al. 873 (ALCB, HUEFS); Jaguaquara, 1330'52"S, 3957'56"W, 625 m s.n.m., out. 2012, E. Melo et al. 11590 (HUEFS); Jequié, 1356'22"S, 40¹1'27"W, 835 m s.n.m., W.W. Thomas et al. 13530 (ALCB); Lençóis, jun. 2001, M.L. Guedes et al. 8967 (ALCB); Maracás, ago. 1975, S. Pereira s.n. (ALCB 10278); Miguel Calmon, $11^{\circ} 23^{\prime} 10^{\prime \prime} \mathrm{S}, 40^{\circ} 31^{\prime} 13^{\prime \prime W}, 1168$ m s.n.m., jun. 2006, R.M. Valadão 63 (ALCB); Morro do Chapéu, jul. 1975, P. Pereira s.n. (ALCB 19964); Mucugê, $13^{\circ} 06^{\prime} 01^{\prime \prime S}, 41^{\circ} 22^{\prime} 32^{\prime \prime} \mathrm{W}$, 1242 m s.n.m., ago. 2014, M. Alves et al. 336 (ALCB); Mulungu do
Morro, 1202'03"S, 41³0'04"W, 1035-1100 m s.n.m., ago. 1999, D.S. Carneiro-Torres et al. 132 (HUEFS); Mundo Novo, fev. 1968, A.L. Costa s.n. (ALCB 4431); Nova Itarana, jul. 1982, K.B. Britto 60 (ALCB, HUEFS); Palmeiras, 12³5'34"S, 41'29'59"W, $983 \mathrm{~m}$ s.n.m., maio 2014, M. Alves 325 (ALCB, HUEFS); Piatã, 1303'52"S, 4150'15"W, jul. 2011, M.L. Guedes et al. 18963 (ALCB); Poções, jun. 2003, G. Hatschbach 75877 (CEPEC); Quijingue, $10^{\circ} 55^{\prime} 20^{\prime \prime} \mathrm{S}, 39^{\circ} 4^{\prime} 59^{\prime \prime} \mathrm{W}, 400-630$ m s.n.m., jul. 2006, $D$. Cardoso \& T.M. Santana 1330 (HUEFS); Ruy Barbosa, 12²6'50"S, 40³9'58"W, jul. 2001, N. Roque et al. 519 (ALCB); Salvador, $12^{\circ} 58^{\prime} \mathrm{S}, 38^{\circ} 30^{\prime} \mathrm{W}$, jul. 2012, F.S. Gomes et al. 1170 (ALCB); Santa Cruz Cabrália, $16^{\circ} 16^{\prime} \mathrm{S}, 39^{\circ} 01^{\prime} \mathrm{W}$, out. 1999, S.S. Lima et al. 140 (ALCB); Santa Teresinha, $12^{\circ} 15^{\prime} 11^{\prime \prime S}, 39^{\circ} 28^{\prime} 31^{\prime \prime W}, 630$ m s.n.m., jul. 2000, J.G.C. Sobrinho 11 (HUEFS); Santo Amaro, 12³2'48"S, 38 42'43"W, jan. 1951, I. Menezes s.n. (RB 528740); Senhor do Bonfim, $10^{\circ} 21^{\prime} 55^{\prime \prime} \mathrm{S}, 40^{\circ} 11^{\prime} 55^{\prime \prime} \mathrm{W}$, jul. 2005, T.S. Nunes 1216 (ALCB, HUEFS); Simões Filho, set. 1975, G. Pina s.n. (ALCB 4432); Vitória da Conquista, 14'51'58"S, 40 $50^{\circ} 22^{\prime \prime} \mathrm{W}$, jun. 1967, O.P. Duarte 10414 (RB); Wenceslau Guimarães, 13³7'08"S, 39³7'57"W, ago. 2001, M.L. Guedes et al. 9530 (ALCB).

Toledo (1942) considerou Verbesina polyanthes distinta das demais espécies do gênero pelas folhas simplicipinadas, decorrentes e capítulos com as flores do raio liguladas. Estas características, entretanto, são encontradas em outras espécies do gênero, incluindo $V$. macrophylla. A partir dos materiais-tipo e dos protólogos das espécies, bem como de extensa análise de material de herbário, verificou-se que não há diferenças morfológicas entre $V$. polyanthes e $V$. macrophylla, as quais serão formalmente sinonimizadas em outro artigo. O espécime (Guedes 18963 - ALCB) apresenta todas as folhas inteiras, entretanto observações em campo demonstraram que essa característica varia entre os indivíduos da mesma população e não deve ser utilizada na separação de táxons.



Figura 43. Mapa de distribuição geográfica de Verbesina macrophylla no estado da Bahia. 
26. Wedelia Jacq.

Ervas ou arbustos, eretos ou prostrados, anuais ou perenes. Folhas opostas; lâmina lanceolada, ovada ou elíptica. Capítulos solitários ou em cimeiras paniculiformes, terminais, radiados; receptáculo convexo, paleáceo; brácteas involucrais em 2-4 séries. Flores do raio femininas; corola do raio verdadeira, amarela, laranja ou alva. Flores do disco bissexuadas; corola tubulosa, amarela ou laranja; anteras geralmente castanhas ou enegrecidas; ramos do estilete com ápice geralmente agudo. Cipselas obovoides ou oblongas, às vezes obcompressas, cinza, castanhas ou enegrecidas, às vezes aladas, glabras ou pubescentes, com cicatriz basal.

Wedelia não possui características diagnósticas que o definam e, a depender do autor, o gênero é delimitado de forma diferente. Panero (2007), por exemplo, considera Wedelia sinônimo de Aspilia e o circunscreve com ca. 300 espécies. Em contrapartida, Santos (2001) considera esses dois gêneros distintos porque Wedelia apresenta flores do raio femininas (vs. neutras) e cipselas sem cicatriz basal (vs. com cicatriz basal), circunscrição adotada aqui. No Brasil, o gênero possui 26 espécies, distribuídas em todas as Regiões (Nakajima et al. 2015); duas espécies são encontradas na Bahia.

\section{Chave para as espécies}

1. Folhas sésseis ou curto-pecioladas (pecíolo até 0,3 cm compr.); lâmina 3-5,4 cm compr., face abaxial estrigosa 26.1. W. bahiensis

1'. Pecíolo 0,6-1,5 cm compr.; lâmina $6,4-11 \mathrm{~cm}$ compr., face abaxial tomentosa

26.2. W. goyazensis

26.1. Wedelia bahiensis H.Rob., Phytologia 55(6): 390. 1984.

Figuras 44 e 49D.

Arbusto ca. 1,5 m alt.; ramos cilíndricos, estriados, estrigosos. Folhas sésseis ou curto-pecioladas (pecíolo até $0,3 \mathrm{~cm}$ compr.); lâmina $3-5,4 \times 0,8-2,6 \mathrm{~cm}$, coriácea, discolor, lanceolada ou ovada, ápice agudo, margem inteira ou serreada, geralmente revoluta, base arredondada, cuneada ou atenuada, estrigosa em ambas as faces. Capítulos 1-3, terminais, 0,9-1,3 × 1-1,5 cm, radiados; pedúnculo 1,9-4,6 $\mathrm{cm}$; invólucro campanulado, brácteas involucrais subiguais, 10-12, 9-12 $\times 3-5 \mathrm{~mm}$, lanceoladas ou ovadas, às vezes as mais internas similares às páleas em textura, ápice agudo ou acuminado, margem inteira, estrigosas, verdes; páleas $10-11 \times$ ca. $2 \mathrm{~mm}$, lanceoladas, conduplicadas, persistentes, geralmente com carena ciliada, apêndice apical ovado, ciliado, face abaxial geralmente glandulosa, ápice agudo, margem inteira. Flores ca. 46. Flores do raio ca. 6, 16-21 mm compr.; corola 13-16 mm compr. (tubo 2-3 mm compr.), amarela; Flores do disco 8,5-10,5 mm compr.; corola 5-6 $\mathrm{mm}$ compr. (tubo ca. $2 \mathrm{~mm}$ compr.), amarela; anteras ca. $3 \mathrm{~mm}$ compr., enegrecidas, apêndice do conectivo ca. 0,5 $\mathrm{mm}$ compr., ovado, amarelo, ápice obtuso, apêndice basal sagitado, filetes amarelos; estilete ca. 5,5 mm compr., amarelo, ramos do estilete ca. $2 \mathrm{~mm}$ compr., ápice agudo, pubescente. Cipselas 4-5 mm compr., oblanceoloides, castanhas, pubescentes, carpopódio inconspícuo; pápus coroniforme, até $1 \mathrm{~mm}$ compr., ápice eroso.

Endêmica do estado da Bahia (Nakajima et al. 2015). E6: campo rupestre. Encontrada com flores e frutos de outubro a março.

Material selecionado - Palmeiras, $12^{\circ} 27^{\prime} 23^{\prime \prime} \mathrm{S}, 41^{\circ} 28^{\prime} 46^{\prime \prime} \mathrm{W}$, 895 m s.n.m., mar. 2002, N. Roque et al. 665 (HUEFS).

Wedelia bahiensis pode ser confundida com a espécie simpátrica Aspilia subalpestris, devido à lâmina foliar coriácea e margem geralmente revoluta, porém distingue-se dela pelas flores do raio femininas (vs. neutras) e lâmina foliar lanceolada a ovada (vs. estreito-elíptica ou elíptica).

\subsection{Wedelia goyazensis Gardner, London J. Bot. 7:} 288. 1848.

Figuras 44, 47A-E e 49E.

Arbusto ca. 1-1,6 m alt.; ramos cilíndricos, estriados, glabrescentes ou tomentosos. Folhas com pecíolo $0,6-1,5 \mathrm{~cm}$; lâmina $6,4-11 \times 2,3-6 \mathrm{~cm}$, cartácea ou coriácea, discolor, lanceolada ou ovada, ápice agudo ou acuminado, margem serreada, base arredondada ou decorrente, face adaxial estrigosa ou setosa, a abaxial tomentosa. Capítulos 1-3, terminais, radiados; $1,1-3,6 \times 0,8-1,7 \mathrm{~cm}$; pedúnculo $0,8-8,1 \mathrm{~cm}$ compr.; invólucro campanulado, brácteas involucrais subiguais, ca. 10, em 2 ou 3 séries, 7-14 × 3-5,5 mm, lanceoladas ou ovadas, ápice agudo ou acuminado, raramente obtuso, margem inteira, verdes, às vezes com ápice verde-escuro ou vináceo, geralmente as mais internas similares as páleas em textura, glabras, com ápice ciliado; páleas 7-8,5 $\times$ ca. $2 \mathrm{~mm}$, lanceoladas, conduplicadas, persistentes, geralmente carenadas, apêndice apical circular, ápice arredondado, margem inteira, ciliada, pubescente na parte apical. Flores 3548. Flores do raio 8 ou 9, 14-22 cm compr.; corola 11$19 \mathrm{~mm}$ compr. (tubo ca. $3 \mathrm{~mm}$ compr.), amarela. Flores do disco 8-10 mm compr.; corola 5-6 mm compr. (tubo 1-2 mm compr., glanduloso), amarela; anteras ca. $3,5 \mathrm{~mm}$ compr., enegrecidas, apêndice do conectivo ca. $0,5 \mathrm{~mm}$ compr., triangular, glanduloso, amarelo, ápice obtuso, apêndice basal sagitado, filetes amarelos; estilete 5,5-8 $\mathrm{mm}$ compr., amarelo, ramos do estilete 2-3 mm compr., ápice agudo. Cipselas ca. 4,5 mm compr., obovoides, castanhas, setosas, carpopódio inconspícuo; pápus coroniforme, ca. 0,5 $\mathrm{mm}$ compr., ápice ciliado.

Registrada para Tocantins, Pernambuco, Goiás e Bahia (Nakajima et al. 2015). B8, B9, C7, C8, D6, D7, E7, E8, E9, F6, F7, G6, G7: cerrado, caatinga e áreas antropizadas. Encontrada com flores e frutos durante todo o ano. 
Material selecionado - Abaíra, $13^{\circ} 17^{\prime} \mathrm{S}, 41^{\circ} 45^{\prime \prime} \mathrm{W}, 830 \mathrm{~m}$ s.n.m., out. 1992, W. Ganev 1394 (ALCB, HUEFS); Boa Vista do Tupim, abr. 1994, L.P. Queiroz \& N.S. Nascimento 3874 (HUEFS); Campo Formoso, 10²9'14"S, 40²7'41"W, abr. 2006 , R.D. Souza et al. 41 (ALCB, HUEFS); Canudos, 0956'34"S, 38॰59'19"W, 400 m s.n.m., jun. 2002, L.P. Queiroz et al. 7239 (ALCB, HUEFS); Euclides da Cunha, $10^{\circ} 30^{\prime} \mathrm{S}, 39^{\circ} 00^{\prime} \mathrm{W}$, mar. 2004, M.L. Guedes et al. 10894 (ALCB); Feira de Santana, $12^{\circ} 15^{\prime} \mathrm{S}$, 38 $58^{\circ} \mathrm{W}$, maio 1982, L.R. Noblick 2692 (HUEFS); Itaberaba, $12^{\circ} 31^{\prime} 12^{\prime \prime} \mathrm{S}, 40^{\circ} 01^{\prime} 35^{\prime \prime} \mathrm{W}, 172 \mathrm{~m}$ s.n.m., jul. 2013, $M$. Alves et al. 256 (ALCB, HUEFS); Iaçu, 12²4'18"S, 3951'48"W, 336 m, jun. 1997, F. França et al. 2331 (HUEFS); Itatim, $12^{\circ} 49^{\prime} 30^{\prime \prime S}, 39^{\circ} 49^{\prime} 40^{\prime \prime W}, 488$ m s.n.m., jul. 2012, E. Melo et al.

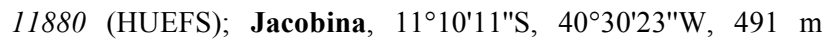
s.n.m., jun. 2011, M. Alves et al. 29 (ALCB); Jeremoabo, $10^{\circ} 00^{\prime} 15^{\prime \prime S}, 38^{\circ} 25^{\prime} 59^{\prime \prime W}, 439$ m s.n.m., E. Melo et al. 6770 (HUEFS); Jussara, $11^{\circ} 05^{\prime} \mathrm{S}, 41^{\circ} 49^{\prime} \mathrm{W}, 610 \mathrm{~m}$, abr. 1984, H.P. Bautista \& O.A. Salgado 928 (HUEFS); Maracás, 13²9'26"S, 40³2'14"W, abr. 2003, abr. 2003, N. Roque et al. 620 (ALCB); Milagres, ago. 2015, L.Y.S. Aona et al. 4203 (ALCB, HURB); Monte Santo, $10^{\circ} 26^{\prime} \mathrm{S}, 39^{\circ} 19^{\prime} \mathrm{W}$, jan. 2006, M.L. Guedes et al. 12120 (ALCB); Morro do Chapéu, 11²9'39"S, 41¹9'53"W, 926 m s.n.m., abr. 2010, M.L. Guedes et al. 17007 (ALCB); Paulo Afonso, $09^{\circ} 45^{\prime} \mathrm{S}, 38^{\circ} 37^{\prime} \mathrm{W}$, maio 1978, J.S. Silva 618 (ALCB, SP); Pindobaçu, 10³0'42"S, 40²0'31"W, 492 m s.n.m., abr. 2006, R.F. Souza-Silva \& V.J. Santos 150 (HUEFS); Piritiba, 11 ${ }^{\circ} 43^{\prime} \mathrm{S}$, 40³3'W, maio 1980, L.R. Noblick 1822 (HUEFS); Poções, 14³0'43"S, 40²1'53"W, 793 m s.n.m., jul. 2013, M. Alves 243 (ALCB, HUEFS); Presidente Jânio Quadros, s.d., C.T. Rizzini \& A.M. Filho 1536 (ALCB, RB); Quijingue, 10 $55^{\circ} 20^{\prime \prime} \mathrm{S}$, 394'59"W, 400-630 m, s.n.m., jul. 2006, D. Cardoso \& T.M.

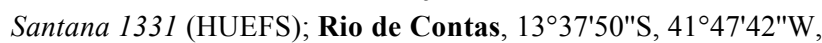
840 m s.n.m., nov. 1996, N. Roque et al. PCD 4525 (ALCB, HUEFS); Salvador, jan. 1993, Alunos de Bot. III s.n. (ALCB 24074); Senhor do Bonfim (Vila Nova), jul. 1912, A. Lutz A. 265

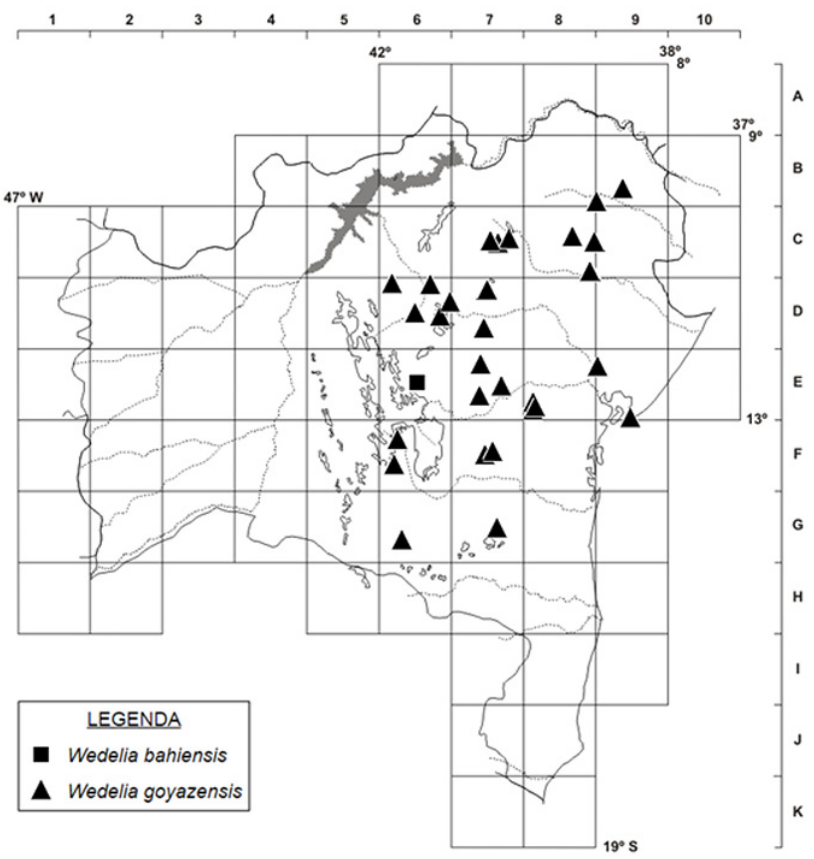

Figura 44. Mapa de distribuição geográfica de Wedelia bahiensis e $W$. goyazensis no estado da Bahia.
(ALCB, SP); Tucano, $10^{\circ} 55^{\prime} \mathrm{S}, 39^{\circ} 04^{\prime} \mathrm{W}$, G. Costa 367 (HUEFS); Várzea Nova, $11^{\circ} 6^{\prime} 10^{\prime \prime} \mathrm{S}, 41^{\circ} 17^{\prime} 22^{\prime \prime} \mathrm{W}, 1016 \mathrm{~m}$ s.n.m., s.d., $E$. Antunes 598 (HUEFS).

Wedelia goyazensis e $W$. villosa foram publicadas juntas, sendo a base da lâmina foliar (cuneada ou atenuada vs. truncada, respectivamente) o caráter mais evidente para distingui-las. Na Bahia, a lâmina foliar é similar a de $W$. goyazensis, não sendo encontrados espécimes com base truncada. Ainda são necessários, contudo, estudos mais abrangentes para uma melhor delimitação entre essas espécies. $\mathrm{Na}$ Bahia, a espécie apresentou plasticidade principalmente em relação à textura das folhas, que variou de coriácea, quando coletada em áreas de Caatinga, a cartácea, em áreas próximas a florestas.

\section{Xanthium L.}

Ervas anuais, às vezes espinescentes. Folhas alternas; lâmina ovada ou deltada, inteira ou lobada. Capítulos discoides, unissexuados, sésseis; os femininos solitários ou agrupados na base de uma capitulescência espiciforme de capítulos com flores funcionalmente masculinas; brácteas involucrais completamente fundidas, adnatas às flores, posteriormente fusionadas às cipselas com projeções uncinadas ou espinhosas nos capítulos femininos, livres nos masculinos; receptáculo paleáceo nos capítulos masculinos e epaleáceo nos femininos. Flores femininas 1 ou 2, sem perianto, as funcionalmente masculinas com corola tubulosa, amarelo-clara ou hialina. Cipselas elipsoides ou estreito-elipsoides, enegrecidas; pápus ausente.

Xanthium pode ser reconhecido pelas brácteas involucrais dos capítulos masculinos livres e dos capítulos femininos completamente fundidas, adnatas às flores e posteriormente fusionadas às cipselas, com projeções uncinadas ou espinhosas (Panero 2007). À primeira vista, o invólucro uncinado do capítulo feminino lembra uma cipsela como em Acanthospermum (Tribo Millerieae), porém é possível observar dois estiletes saindo do ápice da estrutura e, em corte transversal, os dois ovários, permitindo concluir que se trata de um capítulo completo e não um fruto apenas. $\mathrm{O}$ gênero possui três espécies, distribuídas em áreas antropizadas no mundo todo (Panero 2007). Para o Brasil, são citadas duas espécies (Nakajima et al. 2015), ambas encontradas no estado da Bahia.

\section{Chave para as espécies}

1. Ramos com espinhos axilares, trífidos; pecíolo $0,3-$ $0,7 \mathrm{~cm}$ compr.; lâmina foliar estreito-elíptica ou lanceolada, 0,8-1,1 cm larg. ....... 27.1. X. spinosum

1'. Ramos sem espinhos axilares; pecíolo 2,2-7,4 cm compr.; lâmina foliar ovada ou amplamente ovada, 1,9-9,1 cm larg. 27.2. X. strumarium 
27.1. Xanthium spinosum L., Sp. Pl. 2: 987.1753. Figura 45.

Arbusto 0,7-1,5 m alt.; ramos cilíndricos, estriados, vilosos, com espinhos axilares trífidos, 1,1$1,9 \mathrm{~cm}$ compr. Folhas com pecíolo 0,3-0,7 cm compr.; lâmina 3,1-6,1 × 0,8-1,1, cartácea, discolor, estreitoelíptica ou lanceolada, trilobada, ápice acuminado, margem inteira, base atenuada, setosa em ambas as faces. Capítulos masculinos solitários, ao longo da espiga, ca. $3 \times 4 \mathrm{~mm}$; invólucro campanulado, brácteas involucrais ca. $2 \times 1 \mathrm{~mm}$, ovadas, ápice agudo, margem inteira, verdes; páleas ca. $1 \times 0,5 \mathrm{~mm}$, oblongas, ápice truncado, margem inteira, hialinas. Flores ca. 13, 1,5-2 mm compr., ovário inconspícuo; anteras ca. 1,5 mm compr., castanhas, apêndice do conectivo ca. 0,05 mm compr., triangular, ápice agudo, castanho, apêndice basal sagitado, filetes castanhos. Capítulos femininos bifloros, agrupados na base da espiga; invólucro $0,5-1,2 \times 0,4-0,8 \mathrm{~cm}$, elipsoide, uncinado, verde ou castanho na maturidade. Flores com estilete ca. $2 \mathrm{~mm}$ compr., castanho, ramos do estilete ca. 1,5 mm compr., ápice obtuso. Cipselas 6,5$8 \mathrm{~mm}$ compr., estreito-elipsoides, glabras.

A espécie possui registros de ocorrência no continente americano, China e África do Sul (Tropicos 2015). No Brasil, ocorre nas Regiões Sul, Sudeste e na Bahia (Nakajima et al. 2015). E9: áreas antropizadas. Encontrada com flores e frutos no mês de julho.

Material selecionado - Feira de Santana, $12^{\circ} 15^{\prime} \mathrm{W}^{\prime \prime}, 38^{\circ} 58^{\prime} \mathrm{S}$, jul. 2002, S. Santos (HUEFS 61766).

Material adicional examinado - BRASIL. SÃO PAULO: Pindorama, nov. 1938, O.T. Mendes s.n. (ALCB 7203).

Xanthium spinosum é facilmente reconhecida pelos ramos com espinhos axilares trífidos e lâmina foliar estreito-elíptica ou lanceolada, distinguindo-se da outra espécie do gênero que ocorre no Brasil, que possui ramos sem espinhos axilares e lâmina foliar ovada ou amplamente ovada.

27.2. Xanthium strumarium L., Sp. P1. 2: 987. 1753. Figura 45.

Arbusto ca. 0,5 m alt.; ramos cilíndricos, estriados, estrigosos. Folhas com pecíolo 2,2-7,4 cm compr.; lâmina 3-10 × 1,9-9,1 cm, cartácea, discolor, ovada ou amplamente ovada, inteira ou 3-5-lobada, ápice agudo, margem denteada, base cordiforme ou atenuada, estrigosa em ambas as faces. Capítulos masculinos solitários, ao longo da espiga, ca. $2 \times 4 \mathrm{~mm}$; invólucro campanulado, brácteas involucrais ca. 1,5 $\times 0,5 \mathrm{~mm}$, lanceoladas, ápice agudo, margem inteira, verdes, pubescentes; páleas $1,2-1,5 \times$ ca. $0,5 \mathrm{~mm}$, estreitooblongas, ápice truncado, margem inteira, ciliada, hialinas. Flores ca. 15, 2-2,1 mm compr.; ovário inconspícuo; anteras ca. $1 \mathrm{~mm}$ compr., cinéreas, apêndice do conectivo ca. $0,1 \mathrm{~mm}$ compr., ovado, ápice agudo, cinéreo, apêndice basal sagitado, filetes amarelos. Capítulos femininos bifloros, agrupados na base da espiga; invólucro 1,3-1,8 $\times$ 0,9-1,2 cm, elipsoide, uncinado, verde ou castanho na maturidade, glanduloso; estilete ca. $2 \mathrm{~mm}$ compr., castanho, ramos do estilete ca. 1,5 mm compr., ápice obtuso. Cipselas 9-12 mm compr., estreito-elipsoides, glabras.

Xanthium strumarium é registrada no continente americano, China e África do Sul (Tropicos 2015). No Brasil, é citada para as Regiões Sul, Sudeste e Norte (Nakajima et al. 2015), mas também para Bahia (Baker 1884). E9: áreas antropizadas. Encontrada com flores e frutos no mês de janeiro.

Material selecionado - Mata de São João, $12^{\circ} 41^{\prime} \mathrm{S}, 38^{\circ} 19^{\prime} \mathrm{W}$, 2006, M.L. Guedes 13605 (ALCB).

A espécie pode ser reconhecida no gênero pelos ramos sem espinhos axilares e pela lâmina foliar ovada ou amplamente ovada, conforme indicado na chave.

\section{Zinnia L.}

Ervas, anuais ou perenes, ou arbustos. Folhas opostas; lâmina linear, lanceolada, elíptica, oblonga, ovada, obovada ou amplamente ovada. Capítulos solitários ou em cimeiras paniculiformes, terminais, radiados; pedúnculos às vezes fistulosos; brácteas involucrais subiguais ou gradativamente maiores, em 2-5 séries, oblongas ou obovadas, imbricadas, com uma faixa azul-escura ou enegrecida no ápice; receptáculo convexo a cônico, paleáceo. Flores do raio femininas; corola do raio verdadeira, alva, verde, amarela, laranja, vermelha, roxa ou lilás. Flores do disco bissexuadas, às vezes funcionalmente masculinas; corola tubulosa, rosa, vermelha, amarela, amarelo-alaranjada; anteras amarelas, castanhas ou enegrecidas, apêndice do conectivo com ápice agudo, apêndice basal truncado ou sagitado; ramos do estilete filiformes, ápice acuminado, com tricomas ou truncado e penicelado. Cipselas das flores do raio obcompressas, triquetas, às vezes tuberculadas,

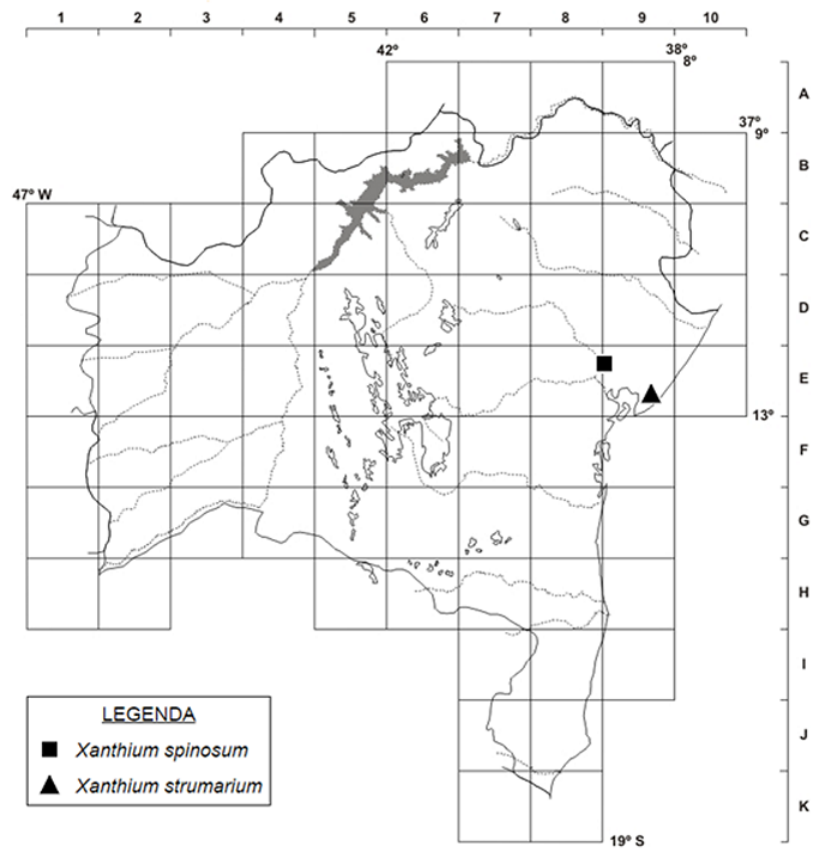

Figura 45. Mapa de distribuição geográfica de Xanthium spinosum e $X$. stumarium no estado da Bahia. 
enegrecidas, castanhas ou acinzentadas, as das flores do disco compressas, geralmente cúbicas, às vezes tuberculadas, às vezes aladas; pápus com 1,2 ou sem aristas.

Zinnia pode ser reconhecido pelas brácteas involucrais oblongas ou obovadas, imbricadas, com ápice geralmente arredondado, eroso e/ou ciliado, e com uma faixa azul-escura ou enegrecida (Torres 1963). O gênero possui cerca de 25 espécies, distribuídas nos Estados Unidos e na região neotropical (Panero 2007). No Brasil e na Bahia, são encontradas duas espécies, ambas naturalizadas.

\section{Chave para as espécies}

1. Capítulo $1,7-2,8 \times 1,2-2,8 \mathrm{~cm}$; invólucro campanulado; páleas $12-14 \times 3-5 \mathrm{~mm}$, estreitoelípticas, com ápice lobado e fimbriado (Figura 47 J); flores 57-159 28.1. Z. elegans

1'. Capítulo ca. 1,4 × 0,9-1,2 cm; invólucro cilíndrico; páleas ca. $10 \times 2 \mathrm{~mm}$, elípticas, com ápice arredondado, eroso, com manchas enegrecidas, glandular; flores ca. 33 28.2. Z. peruviana

28.1. Zinnia elegans Jacq., Icon. Pl. Rar. 3: 15, pl. 589. 1793.

Figuras 46, 47F-J e 49F, G; Jacquin (1793: prancha 589).

Arbusto até $1 \mathrm{~m}$ alt.; ramos cilíndricos, estriados, setosos. Folhas sésseis; lâmina 4,5-10 × 1,5-4,3 cm, cartácea, discolor, ovada, ápice agudo, margem inteira, estrigosa, base truncada, obtusa ou subcordada, estrigosa e glandular em ambas as faces. Capítulos solitários, terminais, 1,7-2,8 × 1,2-2,8 cm; pedúnculo 2,1-8,6 cm compr., fistuloso, seríceo. invólucro campanulado, brácteas involucrais gradativamente maiores, 27-29, em 5 ou 6 séries, as mais externas 3-6 × 3-4 mm, obovadas, as mais internas $9-10 \times$ ca. $5 \mathrm{~mm}$, estreito-elípticas, estriadas, coriáceas, verdes, ápice arredondado, membranáceo, pubescente, margem inteira, ciliada; receptáculo convexo ou cônico, páleas $12-14 \times 3-5 \mathrm{~mm}$, estreitoelípticas, conduplicadas, persistentes, ápice lobado, fimbriado, margem inteira. Flores 57-159. Flores do raio 13-16, em 1-3 séries, 27-37 mm compr., femininas; corola 19-32 mm compr., amarela, laranja, rosa, vermelha ou magenta. Flores do disco 14-16,5 mm compr.; corola 8,5-11 mm compr. (tubo ca. $1 \mathrm{~mm}$ compr.), lacínias com face abaxial velutina, amarela; anteras 3-3,5 mm compr., enegrecidas, apêndice do conectivo ca. $0,5 \mathrm{~mm}$ compr., lanceolado, creme, apêndice basal sagitado, filetes creme; estilete $6,5 \mathrm{~mm}$ compr., amarelo, ramos do estilete $1-1,5 \mathrm{~mm}$ compr., enrolando-se na maturidade, ápice acuminado, papiloso. Cipselas 6-8 × 2,5-4 mm, compressas ou 2ou 3-anguladas, margem ciliada, espessada ou com alas hialinas até $0,5 \mathrm{~mm}$ larg., castanhas com ou sem manchas enegrecidas, glabras ou pubescentes, carpopódio inconspícuo; pápus ausente.
Nativa do México, onde ocorre em áreas até 1560 m s.n.m., mas introduzida em países de todos os continentes (Torres 1963) e naturalizada no Brasil, onde ocorre em todas as Regiões (Nakajima et al. 2015). C7, D6, E8, E9: áreas antropizadas. Encontrada com flores e frutos de março a outubro.

Material examinado - Camaçari, $12^{\circ} 41^{\prime} \mathrm{S}, 38^{\circ} 19^{\prime} \mathrm{W}$, out. 2006, S.T.C. Lima 43 (ALCB); Cruz das Almas, mar. 1953, G.C.P. Pinto s.n. (ALCB 7196); Morro do Chapéu, 11³3'10"S, 41 $09^{\prime} 02 " \mathrm{~W}, 1001 \mathrm{~m}$ s.n.m., abr. 2013, M. Alves \& H.A. Ogasawara 141 (ALCB, HUEFS); Senhor do Bonfim, $10^{\circ} 22^{\prime} 20^{\prime \prime} \mathrm{S}, 40^{\circ} 10^{\prime} 10^{\prime \prime} \mathrm{W}$, 601 m s.n.m., jun. 2001, T.S. Nunes et al. 585 (HUEFS).

Zinnia elegans é cultivada em todo o mundo devido à coloração variada das flores do raio, tamanho do capítulo e à grande quantidade de flores do raio (Torres 1963). Na Bahia, é encontrada em praças, jardins e terrenos baldios no interior do estado.

28.2. Zinnia peruviana (L.) L., Syst. Nat. (ed. 10) 2: 1221. 1759. Chrysogonum peruvianum L., Sp. P1. 2: 920.1753.

= Zinnia multiflora L., Sp. P1. (ed. 2.): 1269. 1763. Figura 46.

Erva 40-60 cm alt.; ramos cilíndricos, estriados, setosos ou tomentosos. Folhas sésseis; lâmina 2,3-4,3 $\times 0,3-0,9 \mathrm{~cm}$, cartácea, discolor, lanceolada ou ovada, ápice acuminado, margem inteira, estrigosa, base truncada ou subcordada, estrigosa e glandular em ambas as faces. Capítulos solitários, terminais, 1,4 $\times$ 0,9-1,2 cm; pedúnculo 1,8-2 cm compr., fistuloso, seríceo; invólucro cilíndrico, brácteas involucrais gradativamente maiores, ca. 18-20, em 3 ou 4 séries, as mais externas $4,1-4,5 \times 2,5-2,8 \mathrm{~mm}$, as mais internas $11 \times 5 \mathrm{~mm}$, elípticas, estriadas, coriáceas, verdes, ápice arredondado, membranáceo, glanduloso,

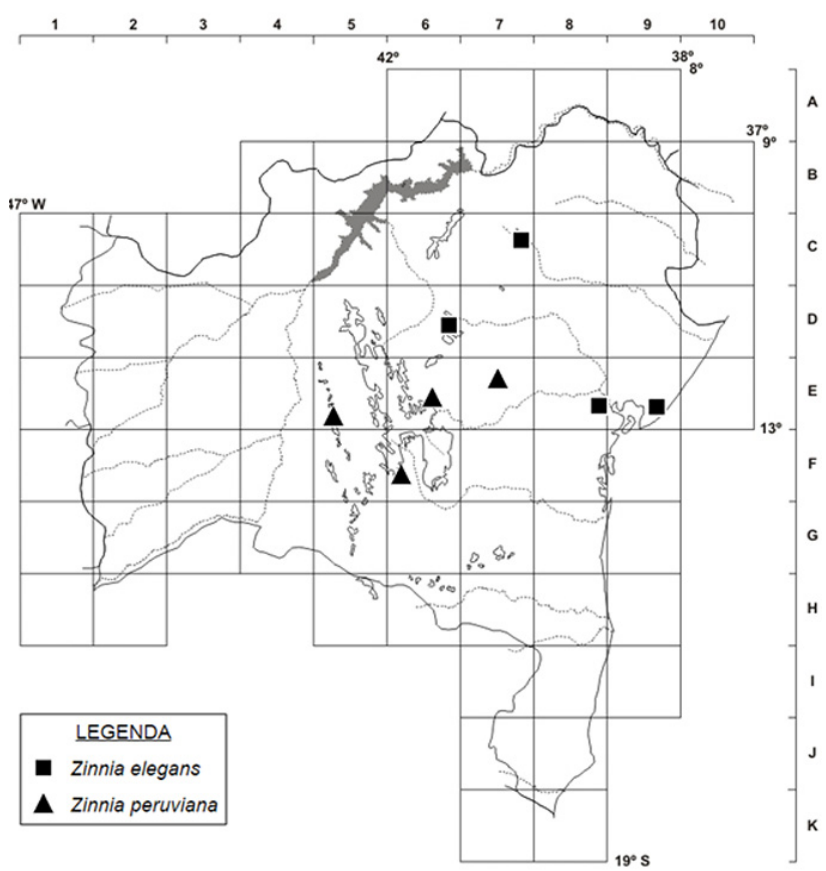

Figura 46. Mapa de distribuição geográfica de Zinnia elegans e Z. peruviana no estado da Bahia. 
margem inteira; receptáculo convexo ou cônico, páleas ca. $10 \times 2 \mathrm{~mm}$, elípticas, conduplicadas, persistentes, ápice arredondado, eroso, com manchas enegrecidas, glandular, margem inteira. Flores ca. 33. Flores do raio ca. 11, em 1 série, 20-21 mm compr., femininas; corola 10-11 mm compr., face abaxial amarela, a adaxial vermelha. Flores do disco 7-12,5 mm compr.; corola 4$6,5 \mathrm{~mm}$ compr. (tubo ca. $0,5 \mathrm{~mm}$ ), lacínias tomentosas na face adaxial, glandulosas na abaxial, vináceas; anteras ca. 1,2 $\mathrm{mm}$ compr., enegrecidas, apêndice do conectivo ca. 0,3 $\mathrm{mm}$ compr., lanceolado, creme, apêndice basal sagitado, filetes creme; estilete ca. $3 \mathrm{~mm}$ compr., amarelo, ramos do estilete $0,5 \mathrm{~mm}$ compr., ápice acuminado. Cipselas do raio ca. $10 \mathrm{~mm}$ compr., 10costadas, oblanceoladas e pubescentes na costa; pápus ausente. Cipselas do disco 3-3,5 mm compr., obovoides, castanhas, carpopódio inconspícuo; pápus com 1 arista de 3-7 mm compr., linear-triangular, pubescente.

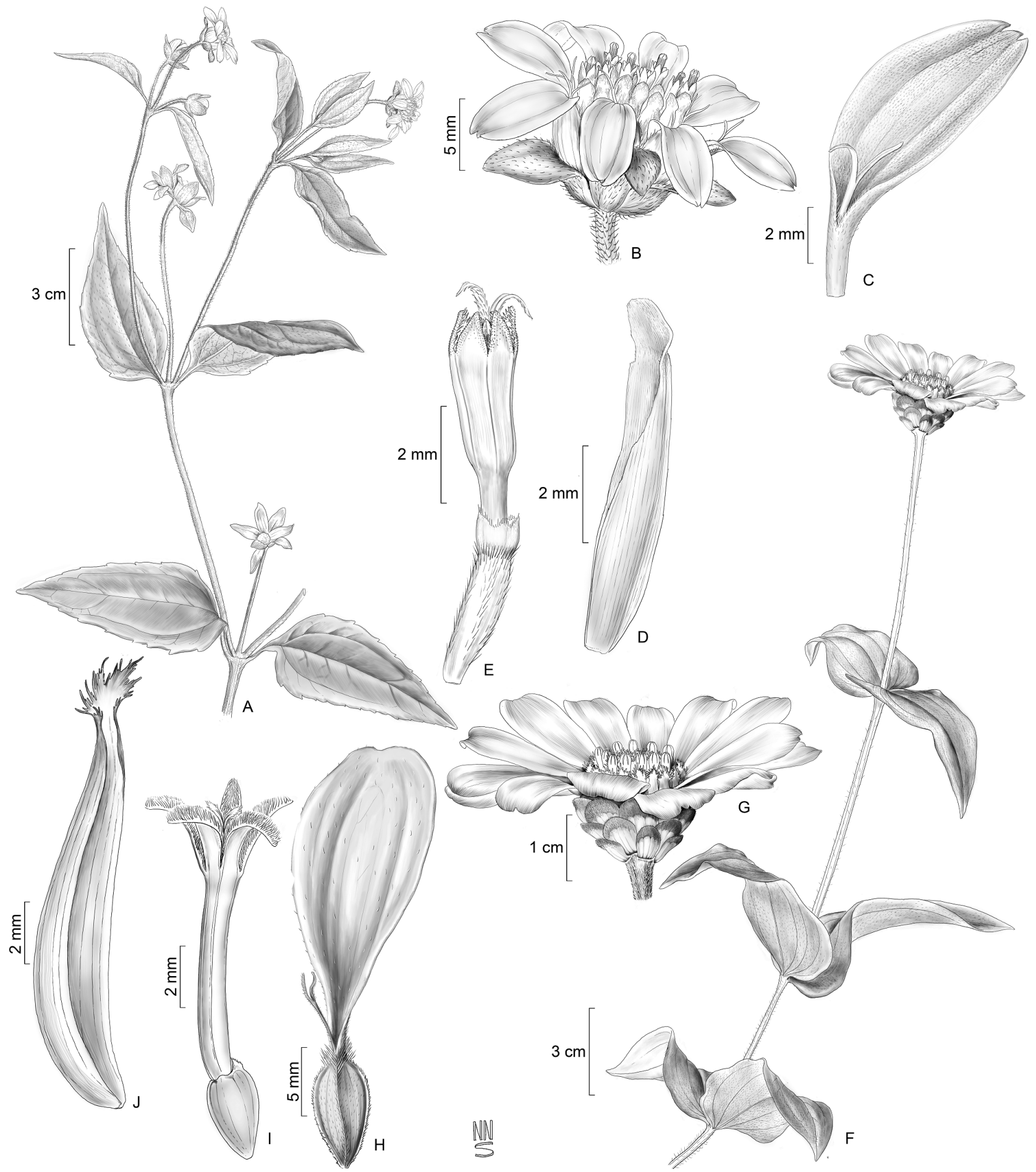

Figura 47. A-E. Wedelia goyazensis: A- hábito; B- capítulo; C- corola feminina; D- pálea; E- flor do disco. F-J. Zinnia elegans: F- hábito; G- capítulo; H- flor do raio; I- flor do disco; J- pálea. (A-E-Alves 256; F-J-Alves 141). 

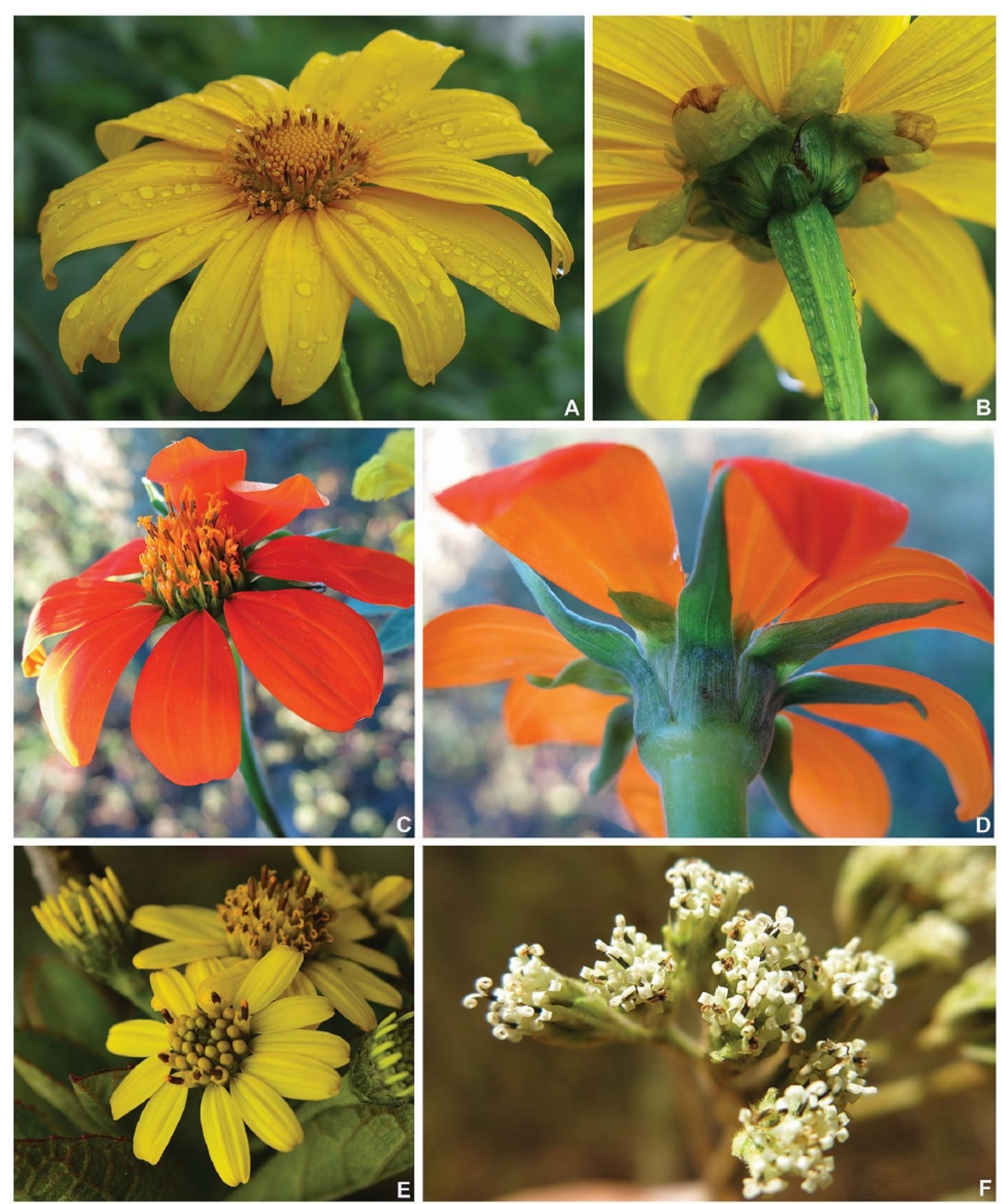

Figura 48. A, B. Tithonia diversifolia: A- capítulo, B- capítulo mostrando pedúnculo fistuloso e brácteas involucrais. C, D. Tithonia rotundifolia: C- capítulo; D- capítulo mostrando pedúnculo fistuloso e brácteas involucrais. E. Verbesina baccharifolia: capítulos. F. Verbesina bipinnatifida: capítulos. (Fotos: A, B, C, D, F- Moura; E- Gandara).

Zinnia peruviana ocorre nos Estados Unidos, México, América Central, Colômbia, Equador, Peru e Argentina, em áreas de até $3000 \mathrm{~m}$ s.n.m. No Brasil, possui registros para o Rio de Janeiro, Minas Gerais e Bahia (Baker 1884), onde é naturalizada. E5, E6, E7, F6: áreas antropizadas. Encontrada com flores e frutos durante todo o ano.
Material selecionado - Boquira, abr. 1966, A. Castellanos 220 (RB); Lençóis, $12^{\circ} 33^{\prime} \mathrm{S}, 41^{\circ} 23^{\prime} \mathrm{W}, 440 \mathrm{~m}$ s.n.m., ago. 2005, S.F. Conceição et al. 267 (HUEFS); Rio de Contas, 13³7'40"S, 4147'55"W, 974 m s.n.m., mar. 2003, R.M. Harley 55100 (ALCB, HUEFS); Ruy Barbosa, $12^{\circ} 18^{\prime} 9^{\prime \prime S}, 40^{\circ} 29^{\prime} 15^{\prime \prime} \mathrm{W}, 477$ m s.n.m., fev. 2006, D. Cardoso et al. 1163 (HUEFS). 

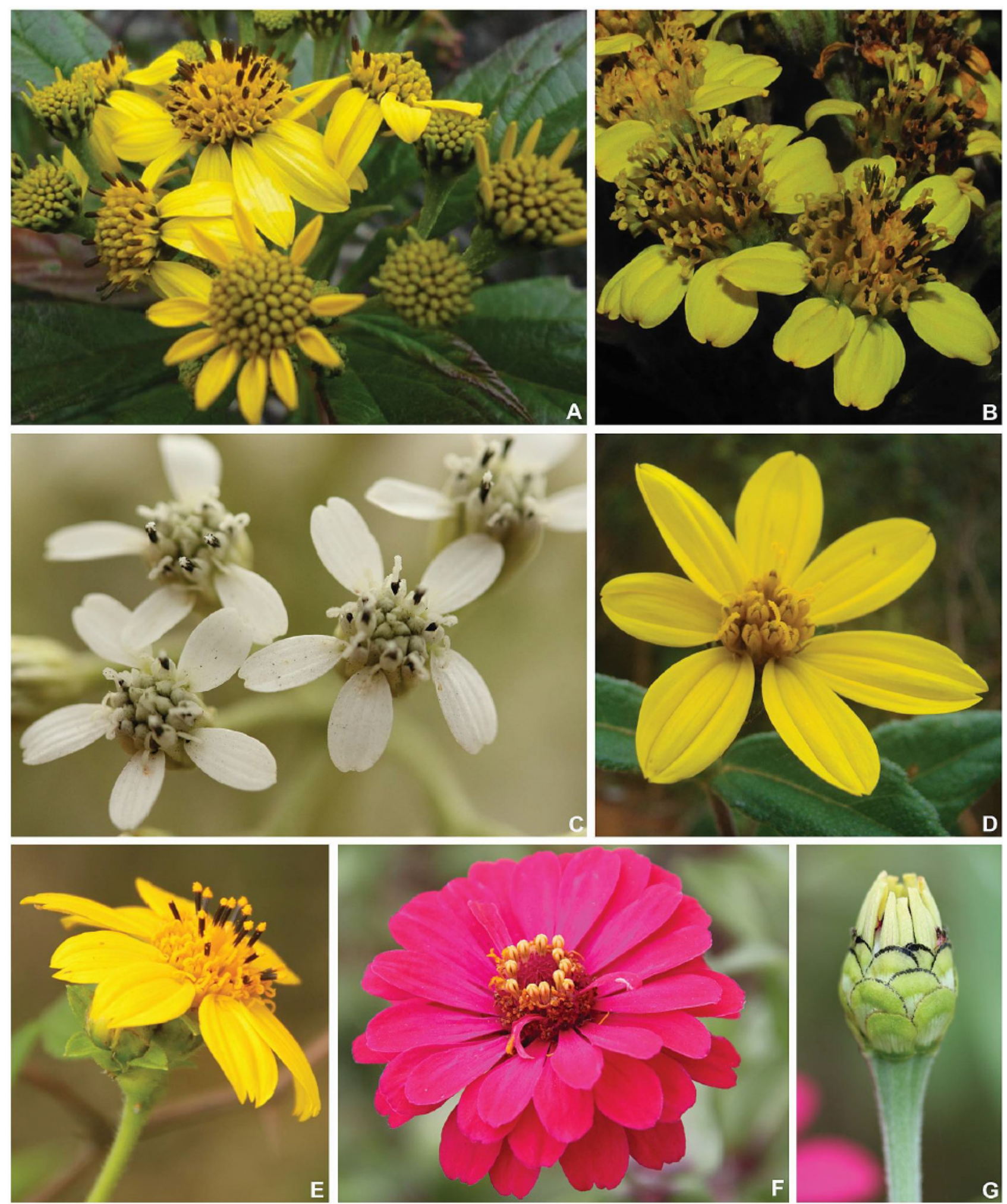

Figura 49. A. Verbesina glabrata: capítulos. B. Verbesina luetzelburgii: capítulos. C. Verbesina macrophylla: capítulos. D. Wedelia bahiensis: capítulo. E. Wedelia goyazensis: capítulo. F, G. Zinnia elegans: F- capítulo; G- capítulo mostrando pedúnculo fistuloso e brácteas involucrais com ápice arredondado e faixa enegrecida no ápice. (Fotos: A- Ribeiro; B- Marques; C, E, F, G- Moura; D- Roque).

Apesar de não ter sido citada por Nakajima et al. (2015) para o Brasil, Baker (1884) descreveu seu sinônimo heterotípico, Z. multiflora, como espécie ruderal que ocorre na Bahia, Minas Gerais e Rio de Janeiro.

\section{AgRAdeCIMENTos}

As autoras agradecem aos revisores deste manuscrito, pelas valiosas sugestões e comentários. Ao $\mathrm{CNPq}$, pela bolsa de mestrado concedida à primeira autora e PQ à segunda. Aos projetos REFLORA 
(CNPq 563541/2010-5), PRONEM (FAPESB PNE0020/2011), Coleções Biológicas (CNPq 504208/2012-8), PROTAX: Flora da Bahia (CNPq $562278 / 2010-9$ ), pelo suporte financeiro às viagens ao campo, materiais de consumo, visita aos herbários e ilustrações; a Natanael Nascimento pelas ilustrações; a Andréia Gandara, Helen Ogasawara, Jôane Coelho, Lúcia Moura, Otávio Marques e Thalisson Ribeiro pelas imagens cedidas.

\section{REFERÊNCIAS}

Alves, M. \& Roque, N. 2016. First record of Sclerocarpus africanus Jacq. (Asteraceae, Heliantheae) for South America. Check List 12(6): http://dx.doi.org/10.15560/12.6.2003.

Alves, M.; Santana, F.A. \& Roque, N. 2015. New records of thirteen Asteraceae from state of Bahia, Brazil. Check List (11)1: $1-5$.

Arriagada, J.E. 2003. Revision of the genus Clibadium (Asteraceae, Heliantheae). Brittonia 55(3): 245-301.

Baker, J.G. 1884. Compositae IV: Helianthoideae. In: C.P. Martius \& A.W. Eichler (eds.). Flora Brasiliensis. Vol. 6, pars 3. Typografia Regia, Monachii, p. 135-268.

Bringel Jr, J.B.A. 2014. Contribuição ao Estudo de Heliantheae (Asteraceae): revisão taxonômica e filogenia de Riencourtia Cass. Tese de doutorado, Universidade de Brasília.

Bye, R.; Linares, E. \& Lentz, D.L. 2009. México: centro de la domesticación del Girasol. Revista Especializada en Ciencias Químico-Biológicas 12(1): 5-12.

Delprete, P.G. 1995. Systematic study of the genus Delilia (Asteraceae, Heliantheae). Plant Systematics and Evolution 194: 111-122.

Baldwin, B.G. 2009. Heliantheae alliance. In: V.A. Funk, A. Susanna, T. Stuessy \& R.J. Bayer (eds), Systematics, Evolution and Biogeography of Compositae. IAPT, Vienna, p. 689-711.

Funk, V.A.; Susanna, A.; Stuessy, T.F. \& Robinson, H. 2009 Classification of Compositae. In: V.A. Funk, A. Susanna, T.F. Stuessy \& R.J. Bayer (eds), Systematics, Evolution, and Biogeography of the Compositae. IAPT, Vienna, p. 171-189.

Gandara, A.; Alves, M. \& Roque, N. 2016. Flora da Bahia: Asteraceae - Tribo Millerieae. Sitientibus série Ciências Biológicas 16: 10.13102/scb844.

Heiser Jr, .C.B. 1957. A revision of the South American species of Helianthus. Brittonia 8(4): 283-295.

Hind, D.J.N. 1993. Notes on the Compositae of Bahia, Brazil: I. Kew Bulletin 48(2): 245-277.

Jansen, R.K. 1981. Systematics of Spilanthes (Compositae: Heliantheae). Systematic Botany 6(3): 231-257.

Jansen, R.K. 1985. The systematics of Acmella (AsteraceaeHeliantheae). Systematic Botany Monographs 8: 1-115.

La Duke, J.C. 1982. Revision of Tithonia. Journal of the New England Botanical Club 84: 453-522.

Magenta, M.A.G. 2006. Viguiera Kunth (Asteraceae, Heliantheae) na América do Sul e Sistemática das Espécies do Brasil. Tese de Doutorado. Universidade de São Paulo.

Magenta, M.A.G. \& Pirani, J.R. 2014. Novidades taxonômicas em Aldama (Asteraceae-Heliantheae). Rodriguésia 65(1): 175-192.
Magenta, M.A.G.; Pirani, J.R. \& Mondin, C.A. 2010. Novos táxons e combinações de Viguiera Kunth (AsteraceaeHeliantheae) no Brasil. Rodriguésia 61(1): 1-11. 2010.

Mondin, C.A. 2004. Levantamento da tribo Heliantheae Cass. (Asteraceae), sensu stricto, no Rio Grande do Sul, Brasil. Tese de Doutorado. Universidade Federal do Rio Grande do Sul.

Mondin, C.A. \& Magenta, M.A.G. Calyptocarpus. In: Lista de Espécies da Flora do Brasil. Jardim Botânico do Rio de Janeiro. Disponível em: <http://reflora.jbrj.gov.br/jabot/floradobrasil /FB16038>. Acesso em: 11 Mar. 2015.

Moraes, M.D \& Semir, J. 2009. A revision of Brazilian Dimerostemma (Asteraceae, Heliantheae, Ecliptinae), with a new species and taxonomic adjustments. Brittonia 61(4): 341365.

Nakajima, J.; Loeuille, B.; Heiden, G.; Dematteis, M.; Hattori, E.K.O.; Magenta, M.A.G.; Ritter, M.R.; Mondin, C.A.; Roque, N.; Ferreira, S.C.; Borges, R.A.X.; Soares, P.N.; Almeida, G.; Schneider, A.; Sancho, G.; Saavedra, M.M.; Liro, R.M.; Pereira, A.C.M.; Moraes, M.D.; Silva, G.A.R.; Medeiros, J.D.; Lorencini, T.S.; Teles, A.M.; Monge, M.; Siniscalchi, C.M.; Souza-Buturi, F.O.; Bringel Jr., J.B. A.; Carneiro, C.R.; Pasini, E. \& Oliveira, C.T. Asteraceae. In: Lista de Espécies da Flora do Brasil. Jardim Botânico do Rio de Janeiro. Disponível em: <http://reflora.jbrj.gov.br/jabot/ floradobrasil/FB55>. Acesso em: 08 mar. 2015.

Ogasawara, H.A. \& Roque, N. 2015. Flora da Bahia: Asteraceae Subtribo Vernoniinae. Sitientibus série Ciências Biológicas 15: $10.13102 / \mathrm{scb} 250$.

Panero, J.L. 2007 [2006]. Tribe Heliantheae Cass. In: Kubitzki, K. (ed.), The Families and Genera of Vascular Plants. Flowering plants. Eudicots: Asterales. Vol. 8. Springer, Berlin, p. 440 477.

Pruski, J.F. 1996. Compositae of the Guayana Highland - XI. Tuberculocarpus gen. nov. and some other Ecliptinae (Heliantheae). Novon 6: 404-418.

Robinson, H. 1984. Studies in the Heliantheae (Asteraceae). XXXII. New species of Wedelia from Brasil. Phytologia 55: 389-414.

Rollins, R.C. 1950. The Guayule Rubber plant and relatives. Contributions from the Gray Herbarium of Harvard University 172: 1-73.

Roque, N. \& Bautista, H.P. 2008. Asteraceae: caracterização e morfologia floral. EDUFBA, Salvador.

Santos, J.U.M. 2001. O gênero Aspilia Thouars (AsteraceaeHeliantheae) no Brasil. Museu Paraense Emílio Goeldi, Belém.

Santos, J.U.M. 1985. Novidades taxonômicas no gênero Aspilia Thouars (Compositae -Heliantheae) de ocorrência brasileira - II. Boletim do Museu Paraense Emílio Goeldi Botânica 2(1): 5-16.

Species Link 2015. Centro de Referência em Informação Ambiental, CRIA. Disponível em http://splink.cria.org.br/tools. Acesso em 8 mar. 2015.

Spooner, D.M. 1990. Systematics of Simsia (CompositeaeHeliantheae). Systematic Botany Monographs 30: 1-90.

Stuessy, T.F. 1973. Revision of the genus Baltimora (Compositeae, Heliantheae). Fieldiana. Botany 36(5): 31-50.

Stuessy, T.F. 1976. A systematic review of the subtribe Lagasceinae (Compositae, Heliantheae). American Journal of Botany 63(9): 1289-1294. 
Stuessy, T.F. 1978. Revision of Lagascea (Compositae, Heliantheae). Fieldiana. Botany 38(8): 75-133.

Toledo, J.F. 1942. Vernonia et Verbesinae novae brasilienses. Arquivo de Botanica Estado Sao Paulo 1(4): 95-98.

Torres, A.M. 1963. Taxonomy of Zinnia. Brittonia 15(1): 1-25.

Tropicos 2015. Tropicos.org. Missouri Botanical Garden. Disponível em http://www.tropicos.org. Acesso em 8 mar. 2015.

Turner, B.L. 1994. Taxonomic study of genus Synedrella (Asteraceae, Heliantheae). Phytologia 76(1): 39-51.
Villaseeñor, J.L. \& Hinojosa-Espinosa, O. 2011. El género Sclerocarpus (Asteraceae, Heliantheae) en México. Revista Mexicana de Biodiversidade 82: 51-61.

Wagner, W.L. \& Robson, H. 2001. Lipochaeta and Melanthera (Asteraceae: Heliantheae Subtribe Ecliptinae): establishing their natural limits and a synopsis. Brittonia 53(4): 536-561.

Zugaib, M. \& Amorim, A.M. 2014. Flora da Bahia: Asteraceae Piptocarpha (Vernonieae: Pitpotcarphinae). Sitientibus série Ciências Biológicas 14: 10.13102/scb705.

\section{LISTA DE EXSICATAS}

Abreu, I.S. 61 (4.13), 63, 78 (10.2), 96 (14.1); Almeida, G.S.S. 17 (6.1); Almeida, M.Z. 9 (20.1), 18 (3.1); Alunos de Botânica III s.n. ALCB 15008 (20.1), s.n. ALCB 24074 (26.2); Alves, L.J. 167 (20.1); Alves, M. 1 (23.1), 6 (21.1), 9, 13 (20.1), 26 (24.1), 27 (15.1), 28 (20.1), 29 (26.2), 30 (24.2), 31 (24.1), 43 (4.14), 44, 45 (4.7), 46 (17.2), 48, 60, 61 (4.7), 64 (4.14), 67, 69 (4.7), 71, 73 (4.5), 74 (23.1), 82 (4.9), 96 (13.1), 97 (17.1), 100 (6.1), 101 (23.1), 111 (24.1), 129 (6.1), 136 (24.2), 137 (6.1),139, 140 (24.1), 141 (28.1), 142 (20.1), 166 (1.3), 167 (6.1), 169 (25.2), 176, 179, 184 (2.2), 198 (25.2), 229 (4.6), 243 (26.2), 245, 246, 247 (25.5), 248 (23.1), 249 (20.1), 251 (15.1), 252 (6.1), 256 (26.2), 259 (25.5), 272, 286 (25.2), 289, 291 (20.1), 316 (15.1), 321 (4.11), 325 (25.5), 329, 330 (10.2), 332 (4.13), 335 (6.1), 336 (25.5), 338, 345, 348 (25.3), 370 (20.1), 373 (23.1); Amorim, A.M. 4114 (8.1), 5192 (24.1), 8022 (7.1), 8024 (1.3); Ana, J. s.n. ALCB 26977 (20.1); Anderson, W. 36542, 36680 (17.2), s.n. RB 160444 (6.1); Andrade, H. s.n. ALCB 16545, s.n. HUEFS 3703 (13.1); Andrade, L. s.n. ALCB 24170 (3.1); Andrade, M.J.G. 183 (4.7), 377 (23.1); Andrade, W.C. 15 (21.1), 84 (20.1); Anjos, B.A. 33 (23.1), 34 (21.1); Antunes, E. 598 (26.2); Aona, L.Y.S. 1905 (7.1), 2569 (21.1), 2600 (23.1), 3242 (1.3), 4114 (21.1), 4203 (26.2); Araújo, J. 69 (23.1); Arbo, M.M. 7281 (11.1); Atkins, S. CFCR 14765 (10.2); Azevedo, B. s.n. ALCB 4214 (3.1), s.n. ALCB 4262 (11.1), s.n. ALCB 4483 (20.1), s.n. ALCB 4511 (9.1); Azevedo, C. 300 (4.1); Azevedo, Y.B. s.n. ALCB 21372 (21.1); Bandeira, F.P. 254 (6.1), s.n. ALCB 23525 (23.1), s.n. ALCB 23512 (21.1); Barbosa, E. 1727 (4.6); Barreto, A. 6 (9.1); Barroso, G.M. s.n. ALCB 4266 (11.1); Bastos, C.A. 12 (1.3); Bautista, H.P. 470 (11.1), 497 (21.1), 504 (6.1), 926 (19.1), 928 (26.2), 1002 (25.5), 1030 (15.1), 3205 (2.3), 3212 (4.9), PCD 3457 (3.1), PCD 3458 (1.1), s.n. RB 209670 (23.1); Belém, R.P. 693 (20.1), 702 (11.1), 962 (6.1), 965 (21.1), 1258, 1276 (8.1), 1671 (6.1), 2446 (25.5), 2833 (23.1), 3648 (25.5); Bellintani, M.C. 11 (23.1); Bezerra, L.A. 2 (25.5); Bridgewater, S. 53939 (11.1); Brito, H.S. 63 (25.5), 163 (13.1), 237, 261 (8.1); Britto, A. s.n. ALCB 04214 (3.1); Britto, K.B. 21 (9.1), 23 (15.1), 24 (1.1), 56 (20.1), 60 (25.5), 63 (24.2), s.n. ALCB 16269 (20.1), s.n. ALCB 16319 (15.1); Callejas, R. 1712 (23.1); Campos, G.S. 17 (20.1), 96 (21.1), 112 (25.5); Cardoso, D. 46 (23.1), 100, 145, 490 (26.2), 1163 (28.2), 1330 (25.5), 1331 (26.2), 1349 (9.1); Carneiro-Torres, D.S. 132 (25.5), 374 (11.1); Carneiro, D.S. 73 (4.7); Carvalho, A.M. 969 (4.7), 1021 (4.12), 1309 (8.1), 2963 (19.1), 3019 (4.7), 3754 (19.1), 3846 (11.1), PCD 1051 (4.7); Carvalho, D.M. 7 (15.1), 41 (15.1), 43 (15.1), 87 (15.1), 338 (15.1), 373 (15.1), 422 (15.1); Carvalho, D.N. 14 (25.5), 97 (5.1), 271 (6.1), 302 (5.1), 328 (6.1), 348 (11.1); Carvalho, G.S. 17 (25.5); Carvalho, J.A. s.n. HUEFS 11470 (4.9); Carvalho, P.D. 436 (6.1); CarvalhoSobrinho, J.G. 45 (23.1), 215 (5.1), 222 (15.1), 243 (6.1), 473 (10.1); 622 (17.2); Castellanos, A. 123 (6.1), 26571 (23.1), 220 (28.2), 25072 (25.5); Castro, I.F. 30 (11.1); Castro, M.S. s.n. ALCB 66355 (4.3); Castro, R.M. 1248 (26.2); Cavalcanti, G. 37 (6.1); Conceição, A.A. 607 (25.3), 1674 (4.12), 2295 (6.1), 2976, 3149 (4.12); Conceição, A.S. 100 (20.1), 574, 635 (4.1); Conceição, S.F. 267 (28.2), 979 (23.1); Correia, C. 368 (11.1); Costa, A.L. s.n. ALCB 291 (23.1), s.n. ALCB 4235, s.n. ALCB 4238 (6.1), s.n. ALCB 4239 (6.1), s.n. ALCB 4267 (11.1), s.n. ALCB 4431 (25.5), s.n. ALCB 4488 (20.1), s.n. ALCB 4492, s.n. ALCB 4493 (23.1), s.n. ALCB 19416 (20.1); Costa, G. 3 , 83, 88 (4.7), 367, 468 (26.2); Costa, L.C.B. 65 (25.5); Costa, M.A.A. 58 (25.5); Costa, M.F. i(20.1); Costa-Neto, E.M. 10 (20.1); Cotrim, A. 1526 (4.8), 1649 (17.2); Cruz N.R.S. 15 (25.5); Cunha, M.C.C. s.n. ALCB 4485 (20.1); Discentes da UEFS s.n. HUEFS 3627 (20.1); Duarte, O.P. 10414, 10520 (25.5); Elisabeth, M. s.n. ALCB 27456 (20.1); Equipe de Ecologia s.n. ALCB 4482, s.n. ALCB 16011, s.n. ALCB 16012 (20.1), s.n. ALCB 16014 (11.1), s.n. ALCB 4417 (21.1); Equipe Ecopol s.n. ALCB 92961 (20.1), s.n. ALCB 92967 (8.1); Euponino, A. 488 (8.1); Fernandes, A. 3645 (10.3), 3646 (17.2), s.n. RB 271059 (10.3); Ferraz s.n. RB 77732 (25.5); Ferreira, J.L. 33 (26.2), 71 (1.3); Ferreira, M.S.G. 103 (3.1), 138 (19.1); Ferreira, S.C. 393 (14.1), 323 (25.4); Ferrucci, M.S. 1057 (8.1); Figueroa, L.E. 14 (25.5), 128 (23.1); Folli, D.A. 998 (20.1); Fonseca Neto, F.P. 43 (23.1), 71 (20.1); Fonseca, M.R. 30 (20.1), s.n. ALCB 51876 (23.1); França, F. 1641, 1643 (11.1), 1733 (15.1), 1767 (1.3), 1881 (9.1), 1891, 1993, 2002 (11.1), 2194 (1.3), 2293 (15.1); 2331 (26.2), 2615 (23.1), 3121 (11.1), 3291 (4.2), 3719 (17.2), 3784 (19.1); 3818 (6.1), 3858 (19.1), 3863 (6.1), 3902 (20.1), 4215,4277 (10.2), 4279 (4.1), 4309 (17.2), 5605, 5610 (20.1); Freire, L. 55 (23.1); Freire-Fierro, A. 1904 (11.1); Funch, L. 126 (4.7); Funch, L.S. FCD 127 (26.1), FCD 139 (4.7); Funch, R. 400 (4.7), s.n. HUEFS 40707 (20.1); Gandara, A. 20 (1.3), 48 (19.1), 75 (26.2), 94 (25.2), 98 (25.1), 110 (23.1), 111 , 112 (25.5); Ganev, W. 134 (26.2), 195, 289 (4.7), 312 (25.2), 363 (25.1), 474 (4.7), 497 (4.1), 499 (10.2), 650 (25.4), 870 (4.14), 903 (25.4), 915 (10.2), 1238 (4.7), 1352 (10.2), 1360 (4.1), 1394 (26.2), 1440 (4.1), 1568, 1600 (4.14), 1626 (10.2), 1727 (4.12), 1730,1731 (4.7), 1732 (4.13), 1753 (23.1), 1758 (4.13), 1759 (17.2), 1788 (4.13), 1799 (10.2), 1824 (25.4), 2108 (4.1), 2192 (4.7), 2625 (10.2), 2626 (4.1), 2767 (4.1), 2833 (4.1), 2861 (4.13), 2883 (17.2), 2885 (10.2), 2897 (4.13), 3190 (4.14), 3224, 3386 (4.1); Giulietti, A.M. 1518 (25.4), 1563 (4.7), 1655 (6.1), 1699 (19.1), 1700 (14.1), 1813 (19.1), 1906 (1.3), 2191 (4.13), 2522 (4.9), 18183 (4.14), PCD 803 (4.7); Gomes, D.J. 40 (15.1); Gomes, F.S. 1111 (24.1), 1170 (25.5), 1216 (11.1); Gonçalves, J.M. 38, 78 (25.5), 166 (19.1), 233 (6.1); Groppo, M. 1041 (20.1); Grupo Pedra do Cavalo 31 (11.1), 69 (15.1), 274 (6.1), 360 (3.1), 368 (9.1), 632 (21.1), 665 (25.5); Guedes, M.L. 2 (12.1), 7 (21.1), 9 (20.1), 17 (11.1), 443 (23.1), 674 (4.7), 804 (2.8), 1107, 1530, 1561 (4.7), 1946 (25.5), 2566 (6.1), 2767 (19.1), 3034 (23.1), 3255 (20.1), 3263 (8.1), 
3317 (23.1), 3552 (20.1), 3822 (23.1), 3874 (24.2), 3884 (6.1), 3967, 4253 (23.1), 4294 (25.5), 4791 (20.1), 4973 (4.12), 5234 (4.7), 5481 (23.1), 6164 (25.3), 6306 (10.1), 6322 (25.5), 6429 (11.1), 7545 (22.1), 7554, 7561 (6.1), 7626 (25.5), 7630 (23.1), 8267 (20.1), 8967 (25.5), 9399 (8.1), 9530 (25.5), 9586 (23.1), 10894 (26.2), 11022 (26.2), 11024 (19.1), 11453 (10.2), 11481 (23.1), 11857 (10.2), 12105 (15.1), 12112 (1.3), 12120 (26.2), 12285 (6.1), 12291 (25.2), 12701 (25.3), 12804 (4.14), 13213 (1.3), 13214 (11.1), 13327 (24.1), 13605 (27.2), 13839 (4.7), 14267 (25.2), 14291 (4.7), 14760 (25.2), 15006 (8.1), 15744 (19.1), 16096 (3.1), 16364 (25.5), 16583 (4.7), 16597,16879 (4.14), 16893 (10.2), 17007 (26.2), 17037 (6.1), 17223 (3.2), 17229 (21.1), 17235 (25.5), 17295 (8.1), 17316 (3.2), 17320 (20.1), 17456 (25.5), 17460 (1.2), 17500 (20.1), 17588 (21.1), 17590 (11.1), 17663 (4.14), 18344 (8.1), 18963 (25.5), 19976 (24.1), 20055 (23.1), 20683 (11.1), 20751 (9.1), 20789 (9.1), 20893 (1.3), 20979 (23.1), 21105 (8.1), 21519 (24.1), 21789 (25.5), 21945 (10.2), 22195 (26.2), 22876 (23.1), 23102, 23259 (20.1), 23485 (28.2), PCD 492 (4.7), PCD 493 (4.12), PCD 498 (26.1), PCD 623, PCD 0389 (4.7), PCD 1946 (25.5), PCD 1970 (4.7), PCD 1973 (4.14), PCD 3011 (1.1), PCD 3055 (11.1), PCD 5047 (10.2), s.n. ALCB 23799 (25.5), s.n. ALCB 23806 (15.1), s.n. ALCB 25243 (24.1), s.n. ALCB 27553 (23.1), s.n. ALCB 27554 (13.1), s.n. ALCB 60446 (4.7); Gusmão, E.F. 162 (23.1), 222 (9.1); Hage, J.L. 134 (23.1), 216, 456 (20.1), 746 (1.3), 971, 988 (1.2), 991 (1.3), 1681, 1837 (20.1), 1942 (21.1), 1943 (11.1), 2249 (20.1), 2268 (25.5); Harley, R.M. 4296 (2.5), 15117 (4.7), 15402 (10.2), 16081 (4.7), 17090 (23.1), 17266 (21.1), 17554 (20.1), 18070 (3.1), 18861 , 19514 (4.7), 19904 (10.2), 19936 (10.2), 20663 (4.7), 20741 (25.4), 21400 (6.1), 21629 (9.1), 21631 (1.3), 21718 (19.1), 21871 (17.2), 21874 (8.1), 21911 (2.8), 21987 (19.1), 22188 (8.1), 22222 (20.1), 22247 (26.1), 22290 (4.7), 22792 (25.3), 22797 (25.3), 25850 (11.1), 26469 (4.14), 26502 (10.2), 26660, 26915 (4.7), 26917 (4.14), 26975 (4.7), 27203 (10.2), 27287 (4.1), 27575 (10.2), 27732 (17.2), 27799 (4.7), 28304 (25.4), 53647 (1.3), 53794 (19.1), 54091 (10.2), 54441 (4.7), 54812, 54844 (1.3), 54860 (26.2), 54997 (19.1), 55024 (10.2), $55088 \mathrm{~A}$ (4.1), 55100 (28.2), 55495 (25.4), H 50104 (4.7), H 50353 (4.1), H 50387 (10.2), H 50388 (4.1), H 50442 (4.14), H 50677 (10.2), H 50682 (4.7), PCD 3109 (25.5), PCD 3284 (26.2), PCD 3403, PCD 3446 (6.1), PCD 3447 (9.1), PCD 3688 (4.14), PCD 4284 (4.1), PCD 4307 (25.1); Hatschbach, G. 47414 (10.2), 47535 (4.7), 48319 (25.3), 53432 (10.2), 61905 (19.1), 63275 (25.5), 66082 (17.2), 68445 (11.1), 75450, 75789 (6.1), 75877 (25.5); Hind, D.J.N. 50294 (4.1), 50475 (11.1), 51334 (3.3), 51403 (19.1), H 50292 (10.2), H 50294 (4.1), H 50933, H 51335 (10.2), H 51337 (23.1), H 51404 (6.1), H 51416 (4.13), H 51422 (4.14), P 001 (20.1), PCD 2938 (11.1), PCD 3100 (6.1), PCD 3159 (25.5), PCD 3375 (1.1), PCD 3376 (21.1), PCD 3381 (11.1), PCD 3382 (3.1), PCD 3438 (9.1), PCD 3439 (23.1), PCD 3440 (20.1), PCD 3575 (1.3), PCD 3613 (24.2), PCD 3789 (3.1), PCD 3796 (1.3), PCD 3799 (20.1), PCD 4130 (4.14), PCD 4193 (17.2), PCD 4195 (4.7), PCD 4211 (10.2); Hurbath, F. 84 (4.7), 665 (24.1), 658 (26.1), 673 (25.4); Irwin, H.S. 31309 (23.1), s.n. RB 158212 (23.1); Jardim, J.G. 2510 (4.7), 2821 (23.1), 3413 (11.1), 3664, 3676 (2.8); 859 (19.1), 1291 (20.1), 1362 (4.6), 1691 (20.1), PC 0124 (23.1), PC 0133 (25.5), PC 0143 (4.9); King, R.M. 7995 (6.1), 8015 (25.5), 8055 (25.4), 8100 (25.3), 8174 (25.4); Kuniyoshi, N. 9 (21.1); Leite, K.R.B. 92 (8.1), 200, 229 (23.1); Leite, M.P. 32 (3.1); Lemos 64 (3.1); Lemos, M.J. 17 (11.1); Lima, C.T. 390 (20.1); Lima, H. s.n. RB 298884 (4.7); Lima, J. 280 (4.7); Lima, J.A. 20 (20.1); Lima, L.R. 272 (4.14); Lima, S.S. 140 (25.5); Lima, S.T.C. 43 (28.1), 57 (3.1), 81 (25.5); Lisboa, M.S. 32 (1.3), 40 (20.1), 123 (23.1), 137 (25.5), 237 (20.1); Lobo, C.M.B. 9 (6.1), 53 (4.12); Longa, C.M. 16 (23.1); Lordêlo, R.P. 56-437 (11.1), 57-442 (25.2), 57-768 (1.3); Loeuille, B. 353 (6.1); Loureiro, D.M. 103 (25.5), 127 (6.1), 571 (17.2), 622 (21.1); Luciana, P.O. 11 (25.5); Lutz, A. 265 (26.2); Macedo, D. 3 (20.1); Machado, M. 79 (4.8); Marinho L.C. 521 (4.1), 544 (23.1); Matos, A.G. s.n. HUEFS 38991 (20.1); Matos, A.O. 38 (20.1); Matos, E.N. 192 (23.1), 290 (23.1), 838 (23.1); Matos, F.B. 1892 , 1924 (23.1); Mattos-Silva, L.A. 422 (7.1), 1015 (8.1), 2107 (23.1), 2168 (8.1), 3196, 3414, 4996, 5181 (20.1), s.n. RB 244609 (7.1); Medeiros, E.V.S. 168 (3.2); Melo, E. 1089 (9.1), 1328 (25.5), 1705 (6.1), 1729 (1.3), 1961 (26.2), 2005, 2016, 2023 (11.1), 2204 (1.3), 2293 (15.1), 3153 (11.1), 3965 (25.5), 3967 (23.1), 4583 (27.1), 4739 (19.1), 4859 (26.2), 5072 (25.3), 5159 (15.1), 5401 (20.1), 5662 (5.1), 6371 (15.1), 6420 (11.1), 6631 (23.1), 6708 (23.1), 6770 (26.2), 6826 (3.1), 6829 (11.1), 7753 (4.10), 7938, 7956 (23.1), 7972 (4.12), 8104,8136 (17.2), 8969 (20.1), 9077, 9494 (23.1), 9871 (9.1), 11144 (3.1), 11590 (25.5), 11880 (26.2), 12117 (23.1); 12059 (1.3), 12167 (20.1), PCD 1137, PCD 1186 (4.7); Melo, P.A. 20 (23.1), 31 (1.2), 44 (11.1), 84 (9.1), 89 (11.1), 97 (1.3), 101 (1.2), 145 (23.1); Mendes, O.T. s.n. ALCB 7203 (27.1); Mendonça, R. 1362, 4571, 4589 (17.2); Mendonça, R.C. 4338 (2.9), 4569 (4.8); Menezes, I. s.n. RB 528740 (25.5); Messias, M. 113 (21.1); Miranda-Silva, E. 196 (25.5), Miranda-Silva, E.B. 379 (17.1); Miranda, A.M. 2421 (16.1), 5135 (8.1), 6647 (6.1), 6754 (25.5); Miranda, E.B. 462 (4.1); Miranda, E.E. 24 (25.5), Moraes, A.O. 279 (25.5); Moraes, M.D. 447, 448 (10.1); Moraes, M.V. 493 (21.1), s.n. HUEFS 27945 (27.2); Mori, S. 9470 (4.7), 9869 (11.1), 9984 (5.1), 10104 (20.1), 10288 (7.1), 10531 (23.1), 11617 (11.1), 12024 (8.1), 14310, s.n. RB 199956, s.n. RB 199957, s.n. RB 221857, s.n. RB 221875 (4.7); Moura, L. 32 (13.1), 110 (25.5), 123 (1.3), 125 (11.1), 167 (26.2), 168, 175 (23.1), 187 (4.12); Nascimento, A.F.S. 104 (20.1); Nascimento, F.H.F. 169 (2.5), 229, 629 (25.4); Noblick, L.R. 1010 (6.1), 1025 (20.1), 1077 (21.1), 1091 (6.1), 1106 (11.1), 1249 (4.7), 1315 (11.1), 1529 (23.1), 1822 (26.2), 1847 (1.3), 1923 (25.5), 2126 (23.1), 2132, 2220 (20.1), 2241 (4.12), 2513 (21.1), 2692 (26.2), 2744 (9.1), 2778 (4.7), 3001 (21.1), 3192 (23.1), 3328 (23.1), 3607 (6.1), 3694 (5.1), 3715, 3859 (11.1), 3882 (9.1), 3997 (20.1), 4019 (11.1), 4143 (15.1), 4148 (9.1), 4159 (1.3), 4203, 4232 (5.1), 4276 (1.3), 4336 (9.1), 4345 (15.1), 4411 (21.1), 4439 (11.1), 11024, 15744 (19.1), 17229, 17588, s.n. ALCB 4418 (21.1), s.n. HUEFS 371 (1.3); Nonato, F.R. 865 (26.2), 873 (25.5), 964 (25.3), 1102, 1141 (20.1); Novais, J.S. 15 (15.1), 35 (9.1); Nunes, S. 218 (26.2); Nunes, T.S. 585 (28.1), 872 (4.14), 899 (19.1), 1209 (9.1), 1214 (15.1), 1216 (25.5), 1253 (11.1), 1489 (4.7), 1494 (17.2), 1514 (4.14); Ogasawara, H.A. 11,53 (4.7), 117 (4.14), 193 (10.2), 254 (25.3), 286 (23.1), 329 (2.7); Oliveira, A.A. 156 (4.1); Oliveira, D. 58 (20.1), 63 (23.1); Oliveira, E. 80 (4.7); Oliveira, E.C. 1 (20.1), 26 (4.7), 107 (25.3); Oliveira, E.E.R. 13 (15.1); Oliveira, E.L.P.G. 293 (26.2), 336 (15.1), 754 (1.3); Oliveira, P.P. 93 (23.1); Oliveira, R.P. 71 (2.5), 343 (26.2), 349 (23.1), 431 (11.1), 625 (25.4), 700 (8.1); Orlandi, R.P. 243 (9.1), 483 (3.1), PCD 508, PCD 650, PCD 0278, PCD 0525 (4.7), s.n. RB 123 (23.1); Pabst, G. 8422 (4.15); Pacheco, L.M. 33 (23.1), 42 (1.3), 43 (1.2), 54 (20.1), 87 (11.1), 126 (23.1), 128 (11.1); Paixão, J. 1013 (4.7); Paixão, J.L. 95 (20.1), 1148 (25.3), 1638 (11.1); Passos, L. PCD 5037 (3.3); Passos, L.A. 277 (4.7); Pastore, J.F.B. 1717 (10.3), 2528 (4.1), 3703 (1.3), 3718 (20.1); Pataro, L. 127 (6.1); Paula-Souza, J. 4996 (4.14); Pedroso, R. 7 (25.5); Pereira, A. 194 (4.14); Pereira, A.C. 16 (9.1); Pereira, E. 2016 (25.3), 2218 (4.7), 9533 (4.15); Pereira, J. s.n. ALCB 6146, s.n. ALCB 8648 (25.3); Pereira, P. s.n. ALCB 19943 (15.1), s.n. ALCB 19964 (25.5); Pereira, S. s.n. ALCB 10278 
(25.5); Pereira-Silva, G. 7975 (15.1); Peso, M.C. 2 (16.1), 40 (23.1), 47 (20.1), 61,68 (23.1), 69 (20.1), s.n. ALCB 20378 (23.1), s.n. ALCB 21874 (25.5), s.n. ALCB 21927 (15.1), s.n. ALCB 21930 (11.1); Pina, G. s.n. ALCB 4432 (25.5); Pinto, G.C.P. 52-188, 57-46 (11.1), 231 (17.2), $253-81$ (25.5), 355 (9.1), 42402 (25.5), 42409 (7.1), 42410 (23.1), 42412 (11.1), 42544 (6.1), s.n. ALCB 7183 (9.1), s.n. ALCB 7186 (6.1), s.n. ALCB 7196 (28.1), s.n. ALCB 7202 (25.5), s.n. ALCB 7208 (11.1); Pirani, J.R. 4966 (20.1), 51440 (23.1), H 51489 (17.2), H 51494 (4.13); Popovkin, A.V. 57, 62 (20.1), 897 (11.1), 1775 (23.1); Poveda, A. PCD 0454 (4.12); Prates, A.R. 138 (23.1); Projeto Farmácia da Terra 9 (20.1); Quaresma, A.S. 154 (4.7); Queiroz, A. s.n. ALCB 21467 (25.5), s.n. ALCB 21575 (6.1); Queiroz, E.P. 5343 (23.1); Queiroz, L.P. 39 (3.1), 325 (23.1), 345 (26.2), 1105 (9.1), 1709 (15.1), 1724 (6.1), 1986 (4.12), 3347 (4.14), 3874 (26.2), 4417 (25.4), 4660 (4.9), 4930 (10.2), 5716 (18.1), 5925 (10.1), 5966 (5.1), 6003 (10.1), 6007 (9.1), 6070 (17.2), 6208 (1.3), 7239 (26.2), 7650 (26.2), 9294 (25.5), 10737 (9.1), 10746 (25.5), 12823 (10.1), 13219 (22.1), 13742, 13830 (8.1), 13974 (2.8), 14307 (2.4), 14492 (17.2), 14513 (24.1); Querino, R.N. 1 (1.3); Ramalho, M. s.n. ALCB 75158 (23.1); Ramos, C.E. 318 (25.5); Rezende, S.G. 1645 (23.1); Ribeiro, A. J. 442 (23.1); Ribeiro-Filho, A.A. 166 (23.1), Ribeiro, T. 42 (4.8); Rizzini, C.T. 1536 (26.2); Robinson, H. 1985 (25.4); Rocha, D. 175 (25.5); Rocha, N.E.A. 945 (11.1); Rocha, Z. s.n. ALCB 4240 (6.1), s.n. ALCB 4491 (23.1); Roque, N. 519 (25.5), 607 (4.14), 620 (26.2), 633 (25.2), 645 ALCB 62238 (6.1), 645 HUEFS 66101 (19.1), 648 (4.14), 665 (26.1), 668 (1.3), 819 (4.7), 987 (10.2), 1397, 1476, 1576, 1755 (4.7), 1791 (25.5), 1973 (4.7), 2112 (1.3), 2114 (24.1), 2146 (4.7), 2194 (25.5), 2847 (23.1), 2894 (25.5), 2896 (23.1), 3530 (4.4), 4059 , 4089 (4.7), 4482 (24.1), 4488, 4492 (4.7), 4508 (20.1), 4678 (26.1), FCO 14 (20.1), FCO 51 (21.1), PCD 4523, PCD 4525 (26.2), s.n. 64335 (4.14); Saar, E. 17 (19.1), 50 (3.1), PCD 4888 (4.7); Saavedra, M.M. 956 (4.7); Salimena-Pires, F.R. PCD 2172 (4.7); Sampaio, K. 03 (13.1), Sant'Ana, S.C. 99 (23.1), Sant'Anna, W. s.n. ALCB 4213 (3.1), s.n. ALCB 4487 (20.1), s.n. ALCB 4495 (23.1); s.n. ALCB 21367 (20.1), s.n. ALCB 21380 (11.1), s.n. ALCB 26717 (3.1); Santana, D.L. 133 (20.1), 752 (8.1); Santana, F.A. 12, 109 (23.1); Santana, J.S. s.n. ALCB 97266 (20.1); Santos, A.S. 8 (20.1), Santos, A.K.A. 536 (8.1); Santos, E.B. 14 (6.1), 177 (20.1); Santos, F. s.n. CEPEC 33084, s.n. RB 227862 (6.1); Santos, F.S. 61 (11.1), 72,91 (8.1), 392 (6.1), 418, 498 (8.1); Santos, N.C.R. 20 (20.1); Santos, S. SS 155 (13.1), s.n. HUEFS 61766 (27.1); Santos, T. 3548 (23.1), s.n. RB 261933 (23.1); Santos, T.S. 850 (6.1), 3152 (7.1), 3548 (23.1), 4366 (21.1), 4422 (7.1); Santos, V.J. 426 (6.1), 433 (9.1); Senna, L.R. 75 (4.7); Sicupira, P.R. 30 (20.1); Silva-Castro, M.M. 637 (26.2); Silva, E.M.G.B. 13, 60 (20.1), 77 (13.1), 152 (20.1); Silva, F.B.L. 36 (1.2); Silva, F.H.M. 341, 488 (26.2); Silva, J.A.A. s.n. ALCB 4484 (20.1); Silva, J.S. 618 (26.2); Silva, L.A.M. 25, 2257 (25.5); Silva, L.C. 341 (20.1);Silva, M.I.B. 26 (24.1); Silva, M.M. 255 (26.2), 259 (25.5), 366 (8.1), 470 (1.1); Silva, S.B. 177 (19.1); Sobral, M. 7541 (4.7); Sobrinho, J.G.C. 11 (25.5); Sousa, L.A. 195 (20.1), 222 (26.2); Sousa, N.X.M. 5 (20.1); Souza, E.B. 1352 (25.5); Souza, P. s.n. ALCB 19451 (23.1); Souza, R.D. 41 (26.2); Souza, V.C. 2125 (20.1); Souza-Santos, F. 418 (8.1); Souza-Silva, R.F. 150 (26.2); Stannard, B. H 51751 (17.2), PCD 5671-b (4.14), s.n. CEPEC 87665 (4.7); Stapf, M.N.S. 304 (23.1); Stehmann, J.R. 3826 (25.2); Stradmann, M.T.S. 524 (23.1); Tavares, P. 9 (26.2); Teles, A.M. 20 (6.1), Thomas, W.W. 13530, 13565 (25.5); Torrend, Pr. 187 (9.1), s.n. ALCB 4419 (21.1); Tosto, M.G. 64 (11.1); Tourinho, R. 20 (25.2); Valadão, R.M. 63 (25.5), 390 (8.1); van den Berg, C. 964 (11.1), Vasconcelos, L.V. 472, 551 (20.1), 552, 586, 561 (25.5); Vieira, T. 19 (6.1); Vieira, T.L. 75 (24.2), 125 (20.1); Vinha, S.C. 172 (6.1); Watanabe, M.T.C. 64 (25.4); Webster, L. 25014 (8.1), 25138 (25.5); Xavier, A. B. 353 (23.1). 